\title{
Organizadores
}

Marcelo Werner da Silva

Tatiana Tramontani Ramos

Daniel de Albuquerque Ribeiro

\section{Pesquisas socioespaciais e ambientais}


Organizadores

Marcelo Werner da Silva

Tatiana Tramontani Ramos

Daniel de Albuquerque Ribeiro

\section{Pesquisas socioespaciais e ambientais}


Dados Internacionais de Catalogação na Publicação (CIP) (Câmara Brasileira do Livro, SP, Brasil)

Pesquisas socioespaciais e ambientais [livro eletrônico] : II Seminário de pesquisa do programa de pós graduação em geografia da UFF : campos dos Goytacazes / organização Marcelo Werner da Silva, Tatiana Tramontani Ramos, Daniel de Albuquerque Ribeiro. -- 1. ed. -- São Carlos, SP : Editora Cubo, 2021. $\mathrm{PDF}$

ISBN $978-65-86819-10-6$

1. Espaço geográfico 2. Meio ambiente 3. Sociedade I. Silva, Marcelo Werner da. II. Ramos, Tatiana

Tramontani. III. Ribeiro, Daniel de Albuquerque.

$\mathrm{CDD}-910$

Índices para catálogo sistemático:

1. Espaço geográfico : Geografia 910

Aline Graziele Benitez - Bibliotecária - CRB-1/3129

https://doi.org/10.4322/978-65-86819-10-6 


\section{Sobre os autores}

\section{Adriana Filgueira Leite}

Graduada em Geografia (bacharelado e licenciatura) pela Universidade do Estado do Rio de Janeiro (UERJ). Mestra e doutora em Geografia pela Universidade Federal do Rio de Janeiro (UFRJ). Pós-doutora no Programa de Pós-Graduação em Geografia da UFRJ, sob supervisão do Prof. Dr. Marcelo Lopes de Souza. Professora-associada do Departamento de Geografia da Universidade Federal Fluminense, em Campos dos Goytacazes (UFF/Campos), e do Programa de Pós-Graduação em Geografia da UFF/Campos. Desenvolve estudos sobre riscos e desastres deflagrados por eventos hidrológicos extremos no Norte Fluminense. Coordenadora do Laboratório de Geomorfologia, Hidrologia e Recursos Hídricos (GEOHIDRO). Representante da UFF no Comitê de Bacia Hidrográfica do Baixo rio Paraíba do Sul e Itabapoana (CBH-BPSI) e coordenadora do Fórum do Segmento de Sociedade Civil do CBH-BPSI. Membro da Rede de Pesquisadores em Geografia (Socio)Ambiental. Tem experiência na área de geociências, com ênfase em geomorfologia e hidrologia, atuando também nas seguintes áreas de interface: gestão dos recursos hídricos, gestão de bacias hidrográficas e hidrogeoquímica. Realiza estudos interdisciplinares por meio da abordagem da geografia ambiental.

\section{Arthur Soffiati}

Professor-associado I aposentado da Universidade Federal Fluminense (UFF). Graduado em História. Mestre e doutor em História Social pela Universidade Federal do Rio de Janeiro (UFRJ), especializando-se em História Ambiental. Suas pesquisas buscam associar a história do NorteNoroeste Fluminense com a história da globalização ocidental. Autor de artigos jornalísticos, artigos acadêmicos e de 27 livros.

\section{Bruna Almeida Ribeiro}

Graduada em Geografia pelo Instituto Federal Fluminense (IFF), em Campos dos Goytacazes. Docente em Geografia no CEDERJ, no Rio de Janeiro, e na rede municipal de Campos dos Goytacazes. Mestranda do Programa de Pós-Graduação em Geografia da Universidade Federal Fluminense, em Campos dos Goytacazes (UFF/Campos).

\section{Daniel de Albuquerque Ribeiro}

Graduado em Geografia pela Universidade Católica do Salvador (UCSal). Mestre e doutor em Geografia pela Universidade Federal da Bahia (UFBA). Já atuou na área de planejamento territorial, regularização fundiária e geoprocessamento em empresas estatais e como professor nos cursos de Geografia da UFBA, UCSal, Universidade Federal Fluminense, em Campos dos Goytacazes (UFF/Campos), e na Pós-Graduação em Educação da Universidade do Estado da Bahia (UNEB). Atualmente, realiza estágio pós-doutoral no Programa de Pós-Graduação em Geografia da UFF/ Campos, sendo bolsista do Programa Nacional de Pós-doutorado (PNPD/CAPES). Participante do Grupo de Estudos e Pesquisas de Geografia Histórica (GEOHISTÓRICA).

\section{Edimilson Antônio Mota}

Professor da educação básica em Geografia, das redes estaduais de Minas Gerais e do Rio de Janeiro, de 1994 a 2012. Licenciado em Geografia pela Faculdade Simonsen e em História pela Universidade Estadual de Minas Gerais (UEMG). Mestre em Políticas Sociais pelo Centro de 
Ciências do Homem, da Universidade Estadual do Norte Fluminense Darcy Ribeiro (UENF). Doutor em Educação, com ênfase em Currículo e Linguagem, pela Universidade Federal do Rio de Janeiro (UFRJ). Professor adjunto IV do Departamento de Geografia da Universidade Federal Fluminense, em Campos dos Goytacazes (UFF/Campos). Atua na licenciatura e no Programa de Pós-Graduação em Geografia da UFF/Campos, com pesquisa em ensino de geografia, raça, gênero, religião e paisagem. Coordenador da Ludoteca Étnico-Racial Camilo José Gomes. Pesquisador da Associação Brasileira de Pesquisadores Negros (ABPN).

\section{Elaine Guimarães Godinho}

Licenciada em Letras pela Universidade Federal de Juiz de Fora (UFJF). Especialista em Educação Tecnológica pelo Centro Federal Celso Suckow da Fonseca (CEFET-RJ), em Ensino de Leitura e Produção Textual pela Universidade Federal Fluminense (UFF), em Arteterapia pelo Centro Universitário Fluminense (UNIFLU-FAFIC) e em Psicologia Organizacional pela Rede Futura de Ensino. Docente na Secretaria Estadual de Educação do Rio de Janeiro desde 2000. Atuou como professora tutora no curso de Atualização para Professores (2013-2014) pelo Núcleo de Educação e Cidadania (NUEC) da UFF e como professora formadora no Programa de Gestão da Aprendizagem Escolar, promovido pelo Ministério da Educação (MEC), no período de 2013 a 2014, para professores de língua portuguesa da rede pública. Atuou como professora pesquisadora de Português Instrumental para os cursos técnicos a distância de Segurança do Trabalho, Guia de Turismo, Análises Clínicas e Multimeios Didáticos pelo Instituto Federal Fluminense (IFF), no período de 2015 a 2017. Mestranda em Geografia pela UFF (2019).

\section{Elaine Cristina Ribeiro Mendes Emerick}

Graduada em Geografia e pós-graduada em Educação Ambiental pelo Centro Universitário do Leste de Minas Gerais. Mestranda no Programa de Pós-Graduação em Geografia da Universidade Federal Fluminense, em Campos dos Goytacazes (UFF/Campos).

\section{Elzira Lúcia de Oliveira}

Graduada em Ciências Econômicas pela Universidade Federal de Minas Gerais (UFMG). Mestra e doutora em Demografia pelo Centro de Desenvolvimento e Planejamento Regional da Faculdade de Ciências Econômicas da Universidade Federal de Minas Gerais (CEDEPLAR/ UFMG). Pós-doutora em Geografia pelo Instituto de Geociências da Universidade Estadual de Campinas (IG/UNICAMP). Professora-associada da Universidade Federal Fluminense (UFF), atuando no Departamento de Geografia de Campos (GRC) e no Programa de Pós-Graduação em Geografia (PPG). Coordenadora do Núcleo de Estudos em Espaço e Demografia (NEED). Desenvolve pesquisas nas áreas de vulnerabilidade social e ambiental, demografia da educação, projeção de demandas demográficas, mobilidade populacional e demografia do trabalho.

\section{Erika Vanessa Moreira Santos}

Graduada, mestra e doutora em Geografia pela Universidade Estadual Paulista Júlio de Mesquita Filho (UNESP). Docente da Universidade Federal Fluminense (UFF), atuando no Departamento de Geografia de Campos (GRC) e no Programa de Pós-Graduação em Geografia (PPG). Membro do Núcleo de Estudos Rurais e Urbanos (NERU). Tem experiência na área de Geografia, com ênfase nos seguintes temas: rural-urbano, ruralidade, agricultura familiar, bairros rurais, agricultura urbana e geografia e gênero.

\section{Felício Alves de Azeredo}

Mestrando em Geografia pela Universidade Federal Fluminense, em Campos dos Goytacazes (UFF/Campos). Especialista lato sensu em Novas Tecnologias Aplicadas à Educação pelo Centro 
Universitário FAVENI. Licenciado em Geografia pelo Instituto Federal de Educação, Ciência e Tecnologia Fluminense, campus Campos Centro. Participante do Núcleo de Ensino e Pesquisa sobre Espaço e Currículo de Geografia e Imagem e Multiculturalismo (NEPECGIM) da UFF/ Campos. Professor de Geografia da educação básica na rede privada.

\section{Gabrielle Lorena Gomes da Silva}

Graduanda de Geografia pela Universidade Federal Fluminense, em Campos dos Goytacazes (UFF/Campos). Bolsista do Projeto de Pesquisa, Ensino e Extensão "Espaço urbano e a Pandemia da Covid-19: Conflitos e mudanças das sociabilidades urbanas", Edital PROPPI - PROGRAD - PROEX n 04/2020/UFF. Membro do Grupo de Pesquisa Território e Cidades (TeCidades).

\section{Glauco Bruce Rodrigues}

Graduado em Geografia pela Universidade Federal Fluminense (UFF). Mestre e doutor em Geografia pela Universidade Federal do Rio de Janeiro (UFRJ). Pós-doutor em Geografia pela Universidade Federal da Bahia (UFBA). Professor-associado do Departamento de Geografia da UFF/Campos e do Programa de Pós-Graduação em Geografia (PPG) da UFF/Campos. Desenvolve pesquisas em geografia histórica, ativismos e conflitos sociais. Coordenador do Núcleo de Estudos sobre o Território e Conflitos Sociais.

\section{Jenyffer Vidal Oliveira}

Graduada em Geografia pelo Instituto Federal Fluminense (IFF), em Campos dos Goytacazes. Mestranda do Programa de Pós-Graduação em Geografia pela Universidade Federal Fluminense, em Campos dos Goytacazes (UFF/Campos). Bolsista do Projeto de Pesquisa, Ensino e Extensão "Espaço urbano e a Pandemia da Covid-19: Conflitos e mudanças das sociabilidades urbanas", Edital PROPPI - PROGRAD - PROEX nº 04/2020/UFF. Membro do Grupo de Pesquisa Território e Cidades (TeCidades).

\section{Leandro Bruno Santos}

Graduado, mestre e doutor em Geografia pela Universidade Estadual Paulista Júlio de Mesquita Filho (UNESP). Docente da Universidade Federal Fluminense (UFF), atuando no Departamento de Geografia de Campos (GRC) e no Programa de Pós-Graduação em Geografia (PPG). Coordenador do Núcleo de Estudos em Economia Política Geográfica (NEEPG). Participante das redes Observatório Socioeconômico dos Municípios Produtores de Petróleo do Estado do Rio de Janeiro (OBPETRO) e da Rede Latino-Americana de Espaço e Economia (RELAEE/UERJ). Tem experiência na área de Geografia, com ênfase nos seguintes temas: Estado, mundialização, corporações, reestruturação produtiva e organização industrial. Jovem Cientista do Nosso Estado (JCNE), pela Fundação de Amparo à Pesquisa do Estado do Rio de Janeiro (FAPERJ), e Bolsista Produtividade do Conselho Nacional de Desenvolvimento Científico e Tecnológico (CNPq) Nível 2.

\section{Marcelo Werner da Silva}

Graduado em Geografia (licenciatura e bacharelado) pela Universidade Federal do Paraná (UFPR). Especialista em Urbanismo, Ciudad, Historia pela Universidad Politecnica de Cataluña. Mestre em Geografia pela Universidade Estadual Paulista Júlio de Mesquita Filho (UNESP), campus de Rio Claro. Doutor em Geografia pela Universidade Federal do Rio de Janeiro (UFRJ). Pós-doutor na Universitat de Barcelona (2016/2017). Professor do Departamento de Geografia da Universidade Federal Fluminense, em Campos dos Goytacazes (UFF/Campos). Coordenador do Programa de Pós-Graduação em Geografia da UFF/Campos. Coordenador do Grupo de Estudos e Pesquisas de Geografia Histórica (GEOHISTÓRICA). 


\section{Marcia Aparecida Pereira de Mello}

Mestranda do Programa de Pós-Graduação em Geografia da Universidade Federal Fluminense, em Campos dos Goytacazes (UFF/Campos). Graduada em Geografia pela Fundação São José. Pós-graduada em História do Brasil pela Fundação São José. Professora do curso de Geografia da Universidade do Estado do Rio de Janeiro (UERJ), em consórcio com a Universidade Aberta do Brasil - CEDERJ. Atua também na rede municipal de Laje do Muriaé como professora de Geografia e História no ensino fundamental II.

\section{Marco Túlio Morais Velasque Silva}

Graduando em Geografia (bacharelado) pela Universidade Federal Fluminense, em Campos dos Goytacazes (UFF/Campos). Membro do Núcleo de Estudos Rurais e Urbanos (NERU). Bolsista de Iniciação Científica da Fundação de Amparo à Pesquisa do Estado do Rio de Janeiro (FAPERJ). Desenvolve pesquisa sobre "O rural no noroeste fluminense no contexto da agricultura familiar no século XXI".

\section{Samara Venina Simen de Azeredo Silva Chagas}

Doutora em Engenharia e Ciências dos Materiais pela Universidade Estadual do Norte Fluminense Darcy Ribeiro (UENF). Mestra em Engenharia e Ciências dos Materiais pela UENF. Graduada em Ciências Biológicas e em licenciatura em Geografia pela Universidade do Estado do Rio de Janeiro (UERJ). Mestranda no Programa de Pós-Graduação em Geografia da Universidade Federal Fluminense, em Campos dos Goytacazes (UFF/Campos). Desenvolve pesquisa intitulada "Programa Rio Rural no município de Italva-RJ", fazendo parte do Núcleo de Estudos Rurais e Urbanos (NERU).

\section{Renata Hilel Ribeiro}

Graduada em Geografia pela Universidade Federal Fluminense, em Campos dos Goytacazes (UFF/ Campos). Mestranda do Programa de Pós-Graduação em Geografia da UFF/Campos. Bolsista do Projeto de Pesquisa, Ensino e Extensão "Espaço urbano e a Pandemia da Covid-19: Conflitos e mudanças das sociabilidades urbanas", Edital PROPPI - PROGRAD - PROEX nº 04/2020/UFF. Membro do Grupo de Pesquisa Território e Cidades (TeCidades).

\section{Silvana Cristina da Silva}

Graduada, mestra e doutora em Geografia pela Universidade Estadual de Campinas (UNICAMP). Pós-doutora em Sociologia pela École Normale Supérieure, em Paris. Professora e pesquisadora do Departamento de Geografia e do Programa de Pós-Graduação em Geografia do Instituto de Ciências da Sociedade e Desenvolvimento Regional da Universidade Federal Fluminense, em Campos dos Goytacazes (UFF/Campos). Coordenadora do Grupo de Pesquisa Território e Cidades (TeCidades).

\section{Tatiana Tramontani Ramos}

Professora-associada do Departamento de Geografia da Universidade Federal Fluminense, em Campos dos Goytacazes (UFF/Campos). Coordenadora do Núcleo de Estudos sobre Território e Conflitos Sociais. Membro do quadro permanente e vice-coordenadora do Programa de Pós-Graduação em Geografia da UFF/Campos. Doutora em Geografia pela Universidade Federal do Rio de Janeiro (UFRJ). Mestra, bacharel e licenciada em Geografia pela UFF. Tem experiência na área de geografia urbana, geografia do trabalho, geografia dos conflitos e ativismos sociais. 


\section{Sumário}

8 Apresentação

Organizadores

10 Quadro de uma Ciência Emergente Ruy Moreira

12 SEÇÃo I Geografia e crise pandêmica

13 Ensaio sobre a precarização do trabalho e a crise urbana em tempos de pandemia Tatiana Tramontani Ramos

31 Meio geográfico, cidade e psicoesfera: da pandemia à sindemia global da Covid-19 Silvana Cristina da Silva, Gabrielle Lorena Gomes da Silva, Jenyffer Vidal Oliveira, Renata Hilel Ribeiro

48 Geografia dos Espaços Alternativos, outras possibilidades, novas esperanças Daniel de Albuquerque Ribeiro

\section{SEÇÃO II Geografia histórica}

71 Geografia Histórica como método Glauco Bruce Rodrigues

89 Dom Antônio Salvini (1892-1968): resgate de memória de atuação do padre italiano de Piancastagnaio (Toscana) na Baixada Campista Elaine Guimarães Godinho, Edimilson Antônio Mota

100 Processos socioespaciais e imigrações: italianos, galegos e outros grupos nos séculos XIX e XX em Salvador, Bahia Daniel de Albuquerque Ribeiro

\section{SEÇão III Produção do espaço, agentes e dinâmicas}

119 Escola Quilombola de Quissamã e bairros negros de Itaperuna: para pensar no racismo estrutural

Felício Alves de Azeredo, Marcia Aparecida Pereira de Mello, Edimilson Antônio Mota

132 Vila da Terra: percepção após o reassentamento Elaine C. R. Mendes Emerick ${ }^{a}$ Elzira Lúcia de Oliveira ${ }^{b}$

146 O Noroeste Fluminense e a atividade leiteira: desafios para a agricultura familiar Erika Vanessa Moreira Santos, Samara Venina Simen de Azeredo Silva Chagas, Marco Túlio Morais Velasque Silva

163 Explorando as teorias da firma na geografia econômica Leandro Bruno Santos

\section{SEÇão IV Desafios da geografia ambiental}

179 A Conferência de Estocolmo e as posturas políticas diante da questão ambiental Arthur Soffiati

185 Comportamento espaço-temporal do oxigênio dissolvido e dos coliformes termotolerantes na região do médio/baixo curso do rio Paraíba do Sul, Norte Fluminense, Rio de Janeiro, Brasil

Bruna Almeida Ribeiro, Adriana Filgueira Leite

\section{Seção Final}

203 Análise das dissertações defendidas no Programa de Pós-Graduação em Geografia da UFF/Campos: contribuição para a autoavaliação do programa Marcelo Werner da Silva

\section{6 Índice de autores}




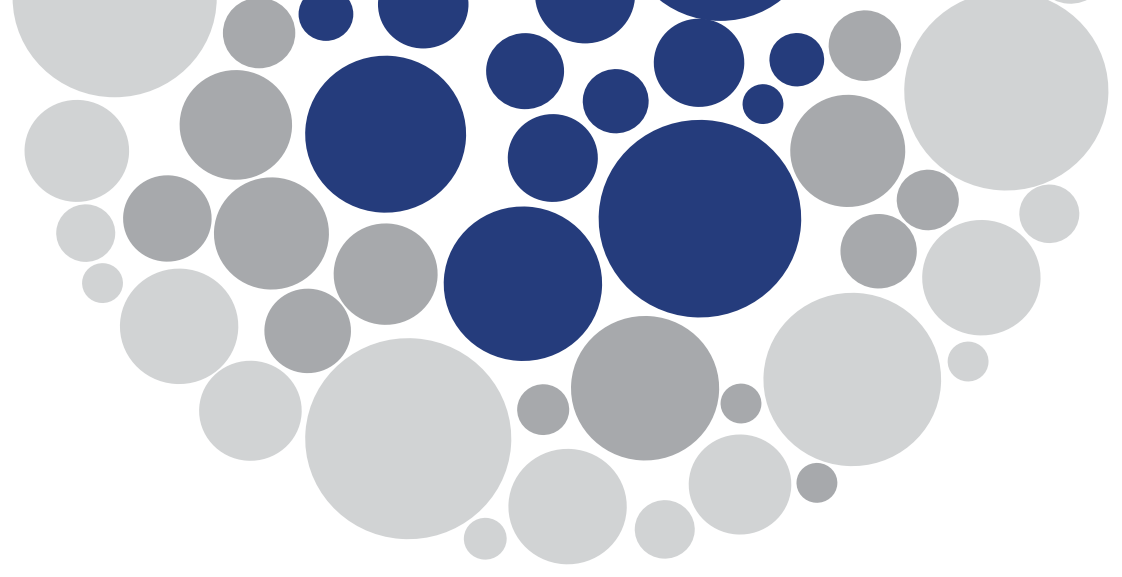

https://doi.org/10.4322/978-65-86819-10-6.a00

\section{Apresentação}

O livro que ora apresentamos se refere a trabalhos expostos na $2^{a}$ edição do Seminário de Pesquisa do Programa de Pós-Graduação (PPG) em Geografia da Universidade Federal Fluminense, em Campos dos Goytacazes (RJ), ocorrido de modo remoto em outubro de 2020. Trata-se de um evento anual realizado pelo PPG como estratégia de publicização e debate crítico de sua produção científica, bem como uma oportunidade de autoavaliação periódica conforme orientam os sistemas de avaliação dos programas de pós-graduação no Brasil.

A sua realização remota, em razão da pandemia de Covid-19, foi encarada pela organização como uma oportunidade de preparar o Programa para esse tipo de evento on-line, o que amplia suas possibilidades de divulgação.

Contamos com o apoio institucional da Universidade Federal Fluminense por intermédio de diferentes instâncias, entre as quais a Pró-Reitoria de Pesquisa, Pós- Graduação e Inovação (PROPPI-UFF) e o Instituto de Ciências da Sociedade e Desenvolvimento Regional de Campos dos Goytacazes (ESR-UFF). A elaboração do evento contou também com recursos do Programa de Apoio à Pós-Graduação da Coordenação de Aperfeiçoamento de Pessoal de Nível Superior (PROAP/CAPES). Portanto, agradecemos imensamente a todos.

Além disso, é necessário mencionar que, direta e indiretamente, tivemos o apoio de vários órgãos de fomento que viabilizaram, por meio da concessão de bolsas e auxílios, a realização de muitas das pesquisas apresentadas nesta produção, quais sejam: o Conselho Nacional de Desenvolvimento Científico e Tecnológico (CNPq), a Coordenação de Aperfeiçoamento de Pessoal de Nível Superior (CAPES) e a Fundação de Amparo à Pesquisa do Estado do Rio de Janeiro (FAPERJ). Por isso, também agradecemos a esses órgãos pelo apoio.

O presente livro é resultado do trabalho de pesquisadores docentes e estudantes do PPG/UFF-Campos e contou com a organização técnica e científica dos coordenadores do 
Programa, Prof. Dr. Marcelo Werner da Silva e Profa. Dra. Tatiana Tramontani Ramos, e do bolsista PNPD/CAPES, Prof. Dr. Daniel de Albuquerque Ribeiro.

Os treze textos que compõem a obra abordam variados temas da pesquisa em Geografia, entre os quais: produção do espaço urbano; geografia ambiental; questões regionais e demográficas; geografia histórica; questão étnico-racial em geografia; geografia rural; geografia econômica e geografia dos conflitos sociais.

A satisfação da conclusão deste livro é proporcional ao êxito do evento e reflete as contribuições de um campus universitário do interior do estado do Rio de Janeiro e de seu Programa de Pós-Graduação em Geografia para o avanço da pesquisa nos diferentes campos da Geografia e suas interfaces.

Marcelo Werner da Silva

Tatiana Tramontani Ramos

Daniel de Albuquerque Ribeiro 


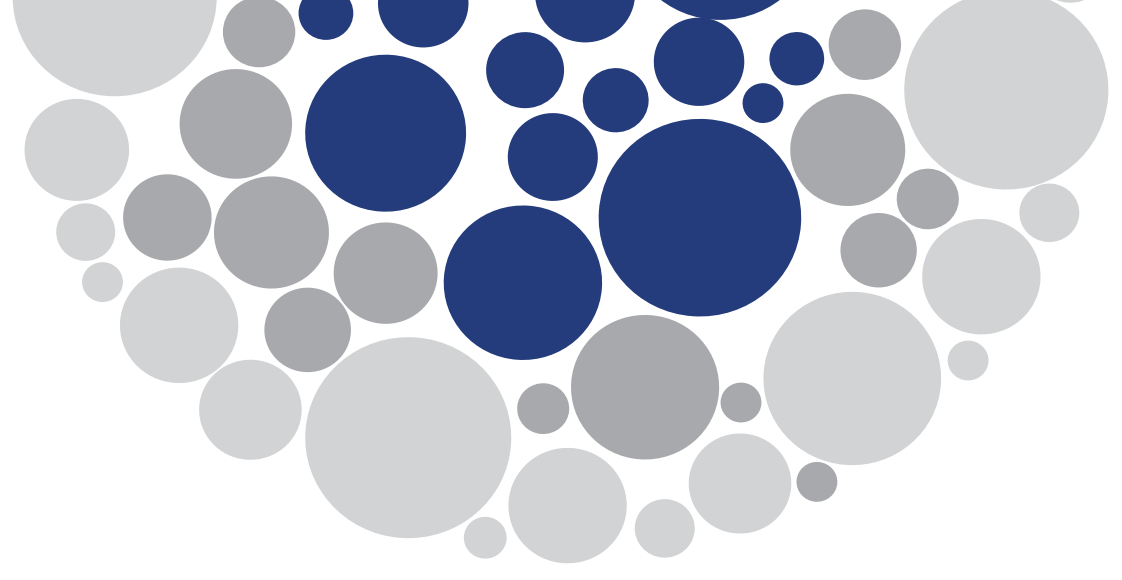

\section{Quadro de uma Ciência Emergente}

Já é hoje vasta a literatura geográfica de origem recente da lavra de uma gama de autores que se ramificam pelos departamentos de graduação, programas de pós-graduação e núcleos de pesquisa, ensejando uma bibliografia invejável no panorama nacional e internacional da geografia como ciência engajada e de senso crítico. É o caso dos professores e pesquisadores da unidade de Campos de Goytacazes da UFF - universidade do privilégio de distintos cursos de graduação e pós-graduação e geografia dos diferentes lugares (Campos, Angra dos Reis e Niterói) do estado do Rio -, seu curso de graduação e pós-graduação e o destaque dos trabalhos de participação em eventos da geografia brasileira, artigos e livros que deles fazem uma fértil e influente fonte de referência entre nós.

Bem na linha da renovação dos anos 1970, sua vinculação a uma teoria mais consistente e a uma tradição inarredável de base empírica, reúnem esses colegas neste livro a riqueza dos temas e visões críticas que desde então tornaram a geografia brasileira conhecida e cortejada em todos os cantos, expressando o casamento bem feito das reflexões discursivas das salas de aula e conferições do trabalho de campo, que o leitor pode ver em cada texto. Do trabalho precarizado às denúncias dos ataques ao meio ambiente, aqui desfilam o problema da concentração fundiária rural e urbana, os sujeitos do espaço, os conflitos de territorialidades, o crescimento das lutas identitárias, a defesa do direito à terra, à cidade, ao trabalho digno e remunerado, que marcam o compromisso da geografia com a sociedade real e mais ampla, em um país de monopólios e distâncias gritantes de desigualdade social e distribuição da renda. Um país onde a riqueza produzida por todos cai, no entanto, nas mãos de uma minoria concentracionista e arbitrária.

Textos que mostram a qualidade e a maturidade a que, acadêmica e cientificamente, chegamos nesta quadra de século, sem abrir mão da independência e consciência crítica face um mecanismo e agências de Estado cada vez mais verticalizados e voltados para a sobrecarga estratégica que afasta a intelligentsia e a universidade das tarefas e do cotidiano a que as chamam os momentos-chave de nossa história, como o que vivemos agora. 
Pois qual poderia ser a função de uma intelectualidade acadêmica que não seja a que os geógrafos e a geografia no longo deste novo tempo têm abraçado desde quando, exprimindo o tempo da retomada da vida democrática do Brasil nos idos dos anos $1970 \mathrm{e}$ 1980, declararam sua opção por uma sociedade socialmente mais igual, economicamente mais justa e ambientalmente mais recíproca? Qual é a linha de compromisso que não a de andar por este país - como na música de Gonzaguinha - para ver e fazer ver que neste país - um Haiti que cada vez mais é aqui, do dizer de Caetano - tudo dá, mas nada é dado, tudo é produzido, mas não nasce, desde quando os verdadeiros moradores foram escorraçados e massacrados como se invasores fossem, para quem o produz, mas sim para os que, às custas deles, tudo usufruem, sem produzir um só níquel. Como diziam os antigos. Qual é a tarefa senão esta, de, na competência e seriedade do trabalho, trazer aos textos este país que merecia uma sorte diferente, absolutamente diferente, da que nós temos. E à qual só chegaremos por meios como este, de produzir e dar a público o conhecimento que ele espera de uma universidade verdadeira.

Textos de uma coletânea que engrandece e enriquece a bibliografia geográfica do país, em um dos seus momentos mais necessários. À leitura, pois. 
SEÇÃO I

Geografia
e crise
pandêmica 


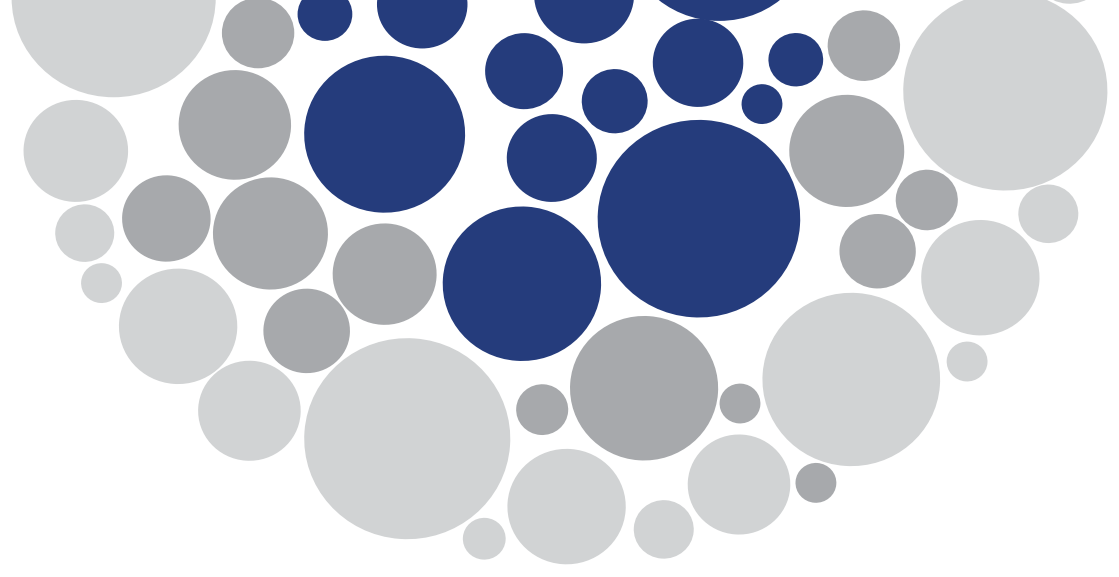

\title{
Ensaio sobre a precarização do trabalho e a crise urbana em tempos de pandemia
}

\author{
Tatiana Tramontani Ramos a \\ a Universidade Federal Fluminense; Departamento de Geografia da UFF/Campos; Programa de Pós-Graduação em Geografia \\ da UFF/CAMPOS, Campos dos Goytacazes (RJ), Brasil. E-mail: tatiana_tramontani@id.uff.br
}

\section{Introdução}

O período atual, por diferentes motivos e intensidades, ficará marcado como um período excepcional da história mundial, e um dos objetos que dá relevo e profundidade muito preocupante à pandemia da Covid-19 é a questão do mundo do trabalho.

Falar de trabalho com questão é tratá-lo como complexo, isto é, multifacetado e diversamente justificado. O trabalho é dotado de densidade histórica, social e cultural, além de conceitualmente definido e interpretado por muitos pensadores ao logo do tempo ${ }^{1}$. Não é nosso objetivo discutir o conceito de trabalho neste texto, mas partimos de uma delimitação materialista e histórica que o percebe como a principal referência na composição do valor e, consequentemente, uma categoria sine qua non do modo de produção capitalista.

Se o trabalho é central em nossa atual condição de existência, não é dispensável ressaltar que ele acompanha as próprias transformações das sociedades, adaptando-se

\footnotetext{
${ }^{1}$ Desde os clássicos Karl Marx e Friedrich Engels, passando por marxistas consagrados, como Georg Lukács, André Gorz, João Bernardo, Edward P. Thompson, Robert Kurz, István Mészáros e Robert Castel, até autores contemporâneos das mais diversas áreas do conhecimento e filiações teóricas, como Claus Offe, Luciano Vasapollo, Maurizio Lazzarato, Giuseppe Cocco, Claudio Dedecca, Benjamin Coriat, Antonio Negri, Michael Hardt, Ricardo Antunes, Márcio Pochmann, Paul Singer, Antonio Thomaz Jr., Ruy Braga, Graça Druck, Maria Cristina Cacciamali, Heleieth Saffioti, Helena Hirata, José Ramalho, Marcelo Badaró, Jessé de Souza, Tom Slee, David Graeber, entre tantos outros e com aproximações e divergências entre eles, nem todos citados no presente texto.
} 
e adaptando-as, em acordo e em conflito com processos outros nos campos da técnica, da norma, das afecções e do espaço-tempo.

Assim como as próprias sociedades, o trabalho como fenômeno social é heterogêneo, desigual, complementar, solidário, produtor e produto de assimetrias - competitivo, concorrencial, predatório etc. Apesar de tomado como uma categoria monolítica e capaz de medir e ser indicativo de uma série de variáveis sociais e econômicas, o trabalho, na maior parte das vezes, não dá conta desse papel, tornando muitas análises incompletas ou mesmo equivocadas, especialmente em sociedades que, por si só, definem-se pela extrema desigualdade e pelas diferenças (qualitativas) entre os sujeitos.

É importante ressaltar ainda que o trabalho é uma das partes constitutivas do principal conflito que resulta da divisão social, o conflito de classes, ou seja, a contradição capital-trabalho. Esse conflito expressa uma contradição, pois pressupõe a exploração e a dominação de uma classe pela outra; neste sentido, não há competição ou concorrência entre as classes, visto que uma se define pela despossessão daquilo que define a outra, os meios de produção. Em outras palavras, se o capital é definido pela posse dos meios de produção - a terra, as empresas, as fábricas, a infraestrutura -, o trabalho (os trabalhadores) é definido pelo seu desapossamento, o que implica uma situação de permanente assimetria e subalternidade, ou seja, a necessidade de submeter à venda sua força de trabalho - sua energia, suas ideias e seu tempo - como forma de obtenção dos meios necessários à reprodução da própria vida.

Nesses termos e condições, a contradição está posta, pois o trabalhador nunca terá as mesmas condições objetivas de afirmação do desejo, das necessidades e opiniões que o capitalista. Por mais que o capitalista dependa da força e trabalho para a reprodução e expansão do capital, ele sempre será resguardado pelo primado da propriedade, enquanto o trabalhador sempre vai depender de uma grande articulação de classe e organização em luta para que o seu poder de enfrentamento seja eficiente ante o capital.

É claro que nesse universo de trabalhadores existe uma enorme variedade de condições para a reprodução dessa força de trabalho que se dá a partir de posições diversas dentro da estrutura social do modo de produção capitalista. Os trabalhadores constituem um conjunto quantitativamente muito amplo e qualitativamente diverso e heterogêneo no que tange ao rendimento, à formação/escolaridade, à estabilidade, ao capital social mobilizável, ao contexto social de origem imediata (família, vizinhança, comunidade). Em outras palavras, identificar o trabalho e os trabalhadores como parte de um mesmo grupo exige, muitas vezes, um esforço de reconhecimento de características que são anteriores às evidências concretas do aqui e agora.

A mesma coisa se dá quando abordamos as transformações recentes do mundo do trabalho, em especial seu processo de notória precarização ${ }^{2}$. Apesar de se tratar de um fenômeno que ganhou muita repercussão recente por conta de processos relacionados à informatização da economia, plataformização ${ }^{3}$ e desregulamentação do trabalho formal, não se pode afirmar peremptoriamente que é um processo recente.

2 cf. Antunes (2001, 2006a, 2006b, 2007, 2020b), Braga (2012, 2017), Graeber (2019), Martins (1997), Mészáros (2006), Montenegro (2014), Ramos (2012a, 2012b, 2014), Thebaud-Mony e Druck (2007) e Vasapollo (2005).

3 cf. Antunes (2020a, 2020b) e Slee (2017). 


\section{A precarização no mundo do trabalho}

Se considerarmos o conjunto de perdas em termos de estabilidade no emprego, regulamentação, direitos e poder aquisitivo dos trabalhadores, a literatura ${ }^{4}$ aponta para uma precarização que já dura mais de quatro décadas nos países centrais da Europa Ocidental e nos Estados Unidos. Essa precarização pode ser traduzida por um conjunto de medidas de flexibilização de legislações trabalhistas expressas na perda de rigor ou mesmo na suspensão de ações ao tratar de proteção social, remuneração e direitos trabalhistas.

Tal processo vem sendo acompanhado por uma forte tendência à terceirização ${ }^{5} \mathrm{e}$ à terciarização. O primeiro é referente a uma substituição da contratação direta por verdadeiras cascatas de subcontratação em termos de mão de obra empregada, o que contribui para o segundo processo, a terciarização maciça da economia, com um contingente cada vez mais amplo de trabalhadores alocados no setor terciário, em especial na prestação de serviços.

Esses trabalhadores tendem a experimentar uma fragilidade maior no que se refere à estabilidade no emprego - vide a alta rotatividade da mão de obra -, além de contratos de trabalho mais frágeis e desvantajosos em termos de direitos, assistência e salários. Neste sentido, tenham os trabalhadores maior ou menor qualificação, especialização ou mesmo escolaridade, nota-se uma inclinação descendente da curva da qualidade de vida nas mais diversas faixas de renda, repercutindo em perdas sociais $\mathrm{s}^{6} \mathrm{em}$ ampla escala.

Esses processos, não raro, foram também inaugurados e experimentados pelos países periféricos por meio da expansão do neoliberalismo, inicialmente de maneira pontual e ensaística e posteriormente de forma planejada e articulada, sobretudo por meio dos Planos de Ajuste Estrutural e suas medidas de "destravamento"/desregulamentação da economia dos países "em desenvolvimento" (cf. SOARES, 2001).

Em termos concretos, essas experiências tem sido levadas a cabo, no caso brasileiro, por uma incorporação já sacramentada da legislação das terceirizações (2017), as emendas constitucionais, que estabelecem tetos para os investimentos em educação, saúde e assistência social, tratados por governos ultraliberais como "gastos" sociais ${ }^{7}$, e as contrarreformas trabalhista (2017) e previdenciária (2019).

As consequências têm sido desastrosas e com expectativa de sensível piora no contexto da grave crise sanitária em que mergulhou o mundo com a pandemia do coronavírus ${ }^{8}$. Se nos países centrais a precarização do trabalho vem sendo responsável por uma sensível queda da qualidade de vida e um "esmagamento" da chamada classe média", com tendência ao seu desaparecimento, nos países periféricos, onde nunca vigorou de forma plena um Estado de bem-estar e uma maior equidade no acesso a bens e serviços essenciais, as consequências têm agravado o que sempre foi problemático, isto é, a atenção às necessidades mais básicas da população - moradia, alimentação, saúde -, bem como

${ }^{4}$ Thebaud-Mony e Druck (2007), Vasapollo (2005) e Braga (2017).

5 Thebaud-Mony e Druck (2007).

${ }^{6}$ cf. Kowarick (1975, 2002, 2003), Martins (1997), Valladares (1994), Souza (2012, 2018), Antunes (2020b) e Braga (2017).

7 PEC do teto de gastos, ou "PEC da morte", de 2016.

8 Em 11 de março de 2020, uma Emergência de Saúde Pública de Importância Internacional foi declarada, e a Covid-19, causada pelo vírus SARS-CoV-2, foi caracterizada pela OMS como uma pandemia, termo esse que se refere à distribuição geográfica da doença, e não, necessariamente, à sua gravidade.

9 Alguns autores vão tratar do tema do "fim da classe média" como o legado de uma era do capitalismo e sua matriz de desenvolvimento. Vide Guilluy (2020) e Souza $(2012,2018)$. 
ampliado o abismo da desigualdade de renda, tornando países como o Brasil o lugar dos extremos ${ }^{10}$ em termos de poder aquisitivo e qualidade de vida.

Outro elemento a ser considerado nesse quadro agravante é o histórico de informalidade identificado nos países periféricos, fenômeno de significativa importância rural, mas não menos relevante em áreas urbanas, metropolitanas ou não.

Os dados da PNAD/IBGE demonstram que o trabalho no Brasil é consideravelmente informal há décadas, com destaque para uma preocupante estabilidade da população ativa na informalidade. Quando restringimos o recorte analítico às áreas metropolitanas, essa proporção se reduz, porém ainda se sustentando em um patamar elevado, superior aos $40 \%$ em quase toda a série histórica. Nas áreas rurais, esses números são ainda mais impactantes. É sabido que a realidade do trabalho rural é diferente e, muitas vezes, implica relações não capitalistas de produção e reprodução da força de trabalho e, consequentemente, o não assalariamento formal. Mas tal realidade, é igualmente sabido, decorre de um processo ampliado e crescente de expulsão do pequeno agricultor em função da expansão do latifúndio e da industrialização do campo ${ }^{11}$, ao qual, muitas vezes, se agrega a ampliação da mão de obra informal, temporária/sazonal e mal remunerada.

Este é um detalhe que se deve ressaltar a respeito do trabalho formal/informal no Brasil: associar o trabalho precário ao trabalho informal como sinônimos é inadequado sob pelo menos dois aspectos ${ }^{12}$.

O primeiro aspecto é por uma questão de generalização problemática. Nem toda precarização leva à informalidade, assim como nem toda informalidade é trabalho precário. A primeira situação pode acontecer em processos de terceirização implementados em setores da indústria, comércio e prestação de serviços, em que os trabalhadores se veem em cargos e funções muito semelhantes àqueles que sempre ocuparam/desempenharam, porém com significativas perdas salariais, bem como em termos de direitos e assistência social. Já a segunda também é representativa do mercado de trabalho brasileiro, mas, de diferentes formas, teve seus exemplos multiplicados na pandemia da Covid-19.

É o caso dos trabalhadores por conta própria, que atuam em pequenas produções domésticas/familiares, e alguns profissionais liberais, que viram seu trabalho em home office se tornar "o novo normal" a partir de 2020. Professores particulares, pequenas produções de alimentos, como doces, "marmitas" e congelados, consultores, entre outros, têm em comum o fato de disporem de alguma infraestrutura domiciliar ou portátil, inclusive com certo coeficiente tecnológico. Conhecimento técnico e superior profissional qualifica seu trabalho e torna as atividades, se não bem remuneradas, ao menos aptas a uma remuneração digna e com certa estabilidade. Assim, o debate sobre a precarização induz uma discussão sobre conquistas e perdas em termos de direitos e garantias, que a questão da informalidade não esgota necessariamente.

O segundo aspecto reside no fato de que a informalidade de baixo rendimento e baixo teor tecnológico está associada a fenômenos não tão recentes e a uma série de insuficiências, carências, inacessibilidades e exclusões, que resultam em impactos geracionais em termos de qualidade de vida e reprodução da força de trabalho. O racismo estrutural e seus vetos à

\footnotetext{
${ }^{10}$ Conforme a Síntese de Indicadores Sociais (SIS) divulgada em 2019 pelo Instituto Brasileiro de Geografia e Estatística (IBGE), com dados até 2018 da Pesquisa Nacional por Amostra de Domicílio (PNAD) e da PNAD Contínua.

${ }^{11}$ Cf. Martins (2010) e Oliveira $(2001,2007)$.

${ }^{12}$ Discussão retomada a partir de Ramos (2012a, 2014).
} 
população preta e o trabalho feminino correspondem a uma ampla parcela dos chamados trabalhadores do cuidado, ou cuidadores. São babás, empregadas, zeladores, vigias/ guardadores etc., que, mesmo subalternizados em uma sociedade que reconhece muito pouco o valor e a importância do cuidado, ainda conseguem alguma inserção objetiva no mercado de trabalho, mesmo informal em sua maioria. Normalmente, essas diferentes ocupações se combinam com outras complementares e ocasionais, que garantem, assim, o mínimo necessário ao sustento das famílias, como sintetiza Montenegro (2014, p. 223-224):

diferentes estratégias de obtenção de renda se combinam para manter um padrão mínimo de consumo entre as famílias pobres nas metrópoles analisadas: multiplicidade de ocupações de um mesmo agente, realização de pequenos serviços e instalação de vendinhas na própria residência, fabricação de produtos caseiros, diversificação das tarefas no pequeno negócio familiar, dentre outras. Estes arranjos apontam para certas manifestações assumidas pela flexibilidade tropical (SANTOS, 1996a) que permitem que a renda seja não só gerada, mas também suficiente para chegar ao fim do mês.

Não se trata de equiparar informais e precários, mas reconhecer elementos estruturais constitutivos de nossa formação social-histórica, que, para além das situações e ocupações descritas anteriormente, também condena parcelas da população ativa a situações de trabalho às quais até mesmo o direito à exploração do assalariamento é negada. A uma ampla parcela dos mesmos sujeitos, homens e mulheres, em sua maioria não brancos, só resta, muitas vezes, a baixíssima remuneração, a imprevisibilidade da renda e a territorialidade instável. Tais atributos corroboram a constituição daquilo que Souza (2008) e, posteriormente, Ramos (2012a, 2012b, 2014) vão caracterizar como um hiperprecariado urbano com características geracionais de longa duração.

Existe uma organicidade nesse mesmo sistema que incorpora e tira proveito desse hiperprecariado, tornando-o parte de uma economia subterrânea, subalterna e necessária. Subterrânea pois é uma economia de "rejeitos", de práticas que se reproduzem em permanente desterritorialização, que não é reconhecida e nem visualizada pela ampla maioria, mas, de alguma forma, está presente, tem utilidade e dá sustentação a indivíduos que interligam-se a outras práticas. É subalterna porque, no que tange às relações de poder que instituem a sociedade, exerce muito pouco dos seus direitos, participa muito pouco das decisões; nesse sentido, é muito pouco autônoma, e disso resulta uma apropriação do espaço que está condicionada não só à sua própria força de organização, mas também aos interesses políticos e econômicos de outros grupos sociais. Por fim, é uma economia necessária não apenas para dar sustento, como meio de sobrevivência, àqueles que a praticam mas, como Milton Santos (1979) já havia sinalizado, a cidade só pode ser entendida a partir de uma teoria do espaço que englobe o conjunto da economia urbana, e não apenas uma parte dela (RAMOS, 2014, p. 24).

A hiperprecarização, neste sentido, pode ser entendida não apenas como um dado constitutivo do nosso mercado de trabalho e de nossa população de modo geral, mas também como um processo (em curso e sempre renovado) que se desenrola e pode se aprofundar, tomando proporções mais dramáticas e até mais brutais, na esteira de diferentes fenômenos que aparentemente só atingiriam o mercado de trabalho formal ou aquele imediatamente periférico a este, mas que sempre tem reflexos sobre a ponta mais frágil da cadeia.

Medidas como os "planos de ajuste estruturais" para a América Latina, consagradas na implantação e aprofundamento de políticas neoliberais para a região nos anos 1990 e início dos anos 2000, foram decisivas para outros fenômenos em cadeia, como a 
desindustrialização, as transformações no modo de regulação e no regime de acumulação (flexibilização e financeirização) e a redução da proteção social (SOARES, 2001). Aparentemente, tais elementos podem sugerir que a precarização e as perdas diretas incidam sobre a classe trabalhadora formal, em situações de maior ou menor exploração, mas, inevitavelmente, irá repercutir nos trabalhadores mais pobres, àqueles aos quais não apenas a formalidade não chega, mas até mesmo o direito à exploração do trabalho assalariado, a famosa "proletarização", muitas vezes é inalcançável.

O empobrecimento das cidades como reflexo imediato do acirramento do neoliberalismo vai atirar maciçamente trabalhadores pobres do setor informal em círculos ainda piores da pobreza e da informalidade. Ao empobrecimento da classe média corresponde automaticamente um empobrecimento dos já pobres, dos trabalhadores e trabalhadoras de baixa renda, principais prestadores de serviços de baixo rendimento, baixa qualificação e baixa incorporação técnica e tecnológica; daqueles que, consequentemente, preenchem setores intensivos em mão de obra. Constitui-se, assim, um heterogêneo universo de trabalhadores informais, formado por todos aqueles que sobrevivem em circunstâncias de grande vulnerabilidade ${ }^{13}$ ou mesmo perigo, morando em espaços desconfortáveis, muitas vezes insalubres ou improvisados, e exercendo ocupações estigmatizadas.

\section{Um mergulho mais profundo na precarização: a pandemia da Covid-19}

Todo esse quadro por si desfavorável no que tange às condições de vida e trabalho no país ganha contornos ainda mais dramáticos quando se instala uma crise de alcance global desencadeada pela pandemia de 2020. Essa crise, inicialmente tratada como uma crise de saúde pública, isto é, sanitária e epidemiológica ${ }^{14}$, logo vai se mostrar também uma das piores crises econômicas e sociais da história ${ }^{15}$, com proporções e impactos distantes de uma solução de curto prazo. Para as economias periféricas, em que as condições de vida já se dão em meio à instabilidade, à precariedade e à forte desigualdade de renda, as consequências têm sido nefastas.

Quando as primeiras medidas de proteção relacionadas à pandemia foram tomadas no Brasil, ainda em março de 2020, as práticas adotadas já vinham sendo implementadas há várias semanas em outras partes do mundo. China, Estados Unidos e vários países da Ásia e Europa já aplicavam medidas de restrição (com variados graus de rigidez e diferentes custos em termos de controle e autoritarismo ${ }^{16}$ ) à circulação nas áreas urbanas mais adensadas - capitais, regiões metropolitanas e algumas cidades de médio porte como tática de contenção da contaminação pelo vírus.

Os principais caminhos conhecidos até então - e meses depois continuam sendo os mais eficazes - eram a redução do contato entre as pessoas ao estritamente necessário

\footnotetext{
${ }^{13} \mathrm{cf}$. Kowarick $(2002,2003)$.

${ }^{14} \mathrm{O}$ acumulado de óbitos no mundo no primeiro trimestre de 2021 já ultrapassou muito o das guerras como a da Coreia, do Golfo (Irã/Iraque) e do Vietnã, conflitos reconhecidamente violentos e catastróficos em perdas humanas. No Brasil, já superamos em óbitos a Guerra do Paraguai (contando as baixas de ambos os lados) ou mesmo das bombas de Hiroshima e Nagasaki.

${ }^{15}$ Além da taxa de desocupação ter quase dobrado em cinco anos, de acordo com dados do Instituto Brasileiro de Geografia e Estatística (2020) a informalidade passou a englobar mais de $40 \%$ da população ocupada, resultando em um contingente de quase 40 milhões de pessoas, o maior valor em quatro anos.

${ }^{16}$ El País: O coronavírus de hoje e o mundo de amanhã, segundo o filósofo Byung-Chul Han. 22 mar 2020 (HAN, 2020).
} 
e, em caso de certa aproximação, a criação de barreiras físicas nem sempre plenamente eficazes, como o uso de máscaras e a higienização constante das mãos e do ambiente.

A primeira medida, a drástica redução do contato entre pessoas, impactou diretamente a circulação e as relações cotidianas, que são o cerne do urbano: estar junto, a proximidade entre as pessoas no viver e no morar, a circulação frenética e permanente, a pluralidade de atividades e relações, a vida predominantemente fora do ambiente doméstico a maior parte do tempo até esse momento. Tudo isso foi duramente interrompido em prol de uma prática até então pouco conhecida ou amplamente discutida: o isolamento social, que, na realidade, é um isolamento físico, visto que os contatos sociais continuam existindo, via telefone, videochamadas, ferramentas diversas de internet, que garantem a manutenção de algumas formas de trabalho, a adaptação de outras e o suprimento parcial de alguns vínculos afetivos. A redução do contato físico a certos núcleos de maior proximidade, em geral os moradores da mesma casa e, em casos mais específicos, os que partilham o mesmo ambiente de trabalho, tornou-se o grande apelo dos órgãos de gestão e controle da pandemia, assim como o desejo daqueles que dimensionavam o tamanho do risco e do problema.

Aí residia, desde sempre, contudo, o nó górdio das medidas contra a pandemia: a questão do trabalho. Para os trabalhadores impossibilitados de se isolarem em trabalho remoto ou se afastarem temporariamente das atividades, por um conjunto de fatores estruturais constitutivo das sociedades capitalistas, periféricas, fortemente desiguais e com atendimento a direitos essenciais, como alimentação, moradia e saúde, escassos para uma parcela significativa da população, o cumprimento e a manutenção do isolamento em suas exigências rigorosas instalaram um dilema e um conflito, bem como fortaleceram, servindo de ilustração e enfrentamento negativo, em muitos momentos, o discurso negacionista e anticientífico de alguns governantes e seus comandados.

Um dilema que, na verdade, é o falso dilema "saúde x economia", que rapidamente se ergueu nas comunicações dos gestores públicos, na imprensa, na mídia televisiva e até mesmo em alguns setores da ciência. Era como se o cuidado de um implicasse a exclusão ou a negligência do outro, necessariamente. Era o dilema entre manter o comércio e escolas fechados e lidar com a avalanche das demissões e a brusca freada da circulação de capital; o dilema entre manter o funcionamento das mesmas atividades (ainda que com certas restrições) e lidar com a avalanche de contaminações e suas sérias consequências doentes, hospitais superlotados, mortes e falta até de espaço em cemitérios. Demorou, no que tange à gravidade da situação, para que medidas mínimas de assistência econômica e social fossem adotadas pelos estados, como o auxílio emergencial ${ }^{17}$, abertura de linhas de crédito para empresas ${ }^{18}$, políticas de apoio e manutenção de empregos formais.

\footnotetext{
${ }^{17}$ Foi aprovado via Projeto de Lei no 9.236/17 em final de março e publicado em 2 de abril de 2020 com o valor de R \$600,00 para os já cadastrados no Programa Bolsa-Família, no CadÚnico e beneficiários de BPC e BF, com a previsão de pagamento de três parcelas prorrogáveis enquanto durasse o estado de emergência. Em meados de abril de 2020, foi aprovado novo Projeto de Lei no 873/2020 (BRASIL, 2020a), que ampliava a lista de categorias a serem beneficiadas. Muitos potenciais beneficiários, contudo, demoraram meses ou nunca sequer conseguiram acessar tal benefício por incapacidade técnica, indigência completa em termos sociais ou falta de resposta dos meios institucionais, o que dá mais relevo às nossas desigualdades estruturais.

${ }^{18}$ Em julho de 2020, o governo federal lançou o Programa Nacional de Apoio às Microempresas e Empresas de Pequeno Porte (Pronampe), linha de crédito destinada a atender pequenos negócios no Brasil que enfrentavam dificuldades por conta da pandemia da Covid-19. O acesso se deu via Banco do Brasil e Caixa Econômica Federal e recebeu incontáveis críticas de beneficiários, que argumentavam não serem admissíveis ao sistema ou aprovados na solicitação, o que inviabilizou o acesso a milhares de empresários (BRASIL, 2020b).
} 
Um conflito porque a disputa de narrativas acirrou um quadro já instalado no país pelo menos desde a segunda eleição da ex-presidente Dilma Rousseff, a polarização e o acirramento entre campos políticos mais progressistas e liberais-conservadores.

Inegavelmente, o princípio básico de tentativa de contenção da pandemia - o isolamento social e as medidas de restrição à circulação - coloca em pauta um debate profundamente geográfico, em que o ordenamento espacial e as práticas socioespaciais irão passar por processos de ressignificação, novas formas de controle e também novas formas de enfrentamento e resistências.

Tais resistências e enfrentamentos estão relacionados ao dilema que foi colocado anteriormente, isto é, à imposição de uma "escolha difícil"19 entre "salvar as pessoas ou salvar a economia”, quando a mitigação dos problemas relacionados a ela deveria ter sido encaminhada por outros meios, como acesso a crédito e auxílios financeiros facilitados. Da mesma maneira, estão também relacionados ao segundo fator o conflito aberto que se instala na sociedade brasileira há quase uma década. As disputas e até mesmo a interdição do debate entre os campos políticos no Brasil tornaram o próprio enfrentamento da pandemia - por meio das medidas amplamente aceitas como eficazes e incontornáveis diante da situação de emergência mundial - um objeto de ataque e de capitalização por sujeitos com interesses eleitorais nada virtuosos.

O negacionismo científico acerca da gravidade da doença, o boicote aos protocolos de higiene e proteção individual e a obstacularização às medidas restritivas de circulação e interação social, associados ao embate intra e entre poderes (executivo, legislativo e judiciário), bem como entre os entes da federação (União, estados e municípios), impuseram um agravamento da crise e, consequentemente, um prolongamento excessivo de um quadro grave de saúde pública e crise social.

Se o isolamento social já se mostrava, no início da crise, inviável para uma parcela considerável de trabalhadores, aqui tratados e definidos a partir de sua origem social-histórica e condições prático-objetivas de sobrevivência, com seu prolongamento indefinido ele se tornou um enclave. Temos um quadro instalado de crise aguda de acumulação e circulação capitalista, associado a quase zero investimento em medidas mitigadoras da crise, seja em assistência, seja em prevenção e saúde (como aquisição de equipamentos e insumos hospitalares ou vacinas já disponíveis no mercado desde dezembro de 2020), diante da proporção do caos.

O Brasil teve uma expressiva queda do PIB no início de 2021, com o pior resultado em trinta anos. Esse acumulado só não foi mais negativo graças ao desempenho do agronegócio, que, diferentemente dos demais setores da economia em queda, apresentou certo crescimento ${ }^{20}$, mesmo em uma situação de crise econômica e social aguda no país por ser um setor cada vez mais independente de mão de obra e também cada vez menos destinado ao consumo direto da população, ou seja, emprega pouco e é pouco impactado pelo consumo direto das famílias.

$\mathrm{Na}$ outra ponta da cadeia, entre os trabalhadores pobres, (hiper)precarizados e que têm sua situação gravemente afetada na pandemia, é possível enxergar uma certa diversidade

\footnotetext{
${ }^{19}$ Parafraseando o Editorial do Estadão, de 8 de outubro de 2018 (ESTADÃO, 2018).

${ }^{20}$ Segundo o IBGE, "em 2020, os serviços encolheram 4,5\% e a indústria, 3,5\%. Somados, esses dois setores representam $95 \%$ da economia nacional. Por outro lado, a agropecuária cresceu 2,0\%. [...] O consumo das famílias teve o menor resultado da série histórica (-5,5\%). Isso pode ser explicado, segundo a coordenadora de Contas Nacionais, principalmente pela piora no mercado de trabalho e a necessidade de distanciamento social" (AGÊNCIA DE NOTÍCIAS, 2021).
} 
de situações, e em todas elas a vulnerabilidade social ${ }^{21}$, a exposição ao risco de doença, a instabilidade de renda, o endividamento ${ }^{22}$ das classes subalternas e precarizadas e a baixa qualidade de vida são fatores cumulativos. Vemos um conjunto diverso de prestadores de serviços diretos de baixa remuneração (manutenção, entregas, cuidado doméstico e patrimonial), balconistas de setores essenciais (mercados e farmácias) e outros trabalhadores ainda mais precarizados que vivem de atividades informais subalternas, sejam elas ocasionais ou permanentes, como camelôs, ambulantes, "guardadores de carro", entre outras pequenas formas de comércio e prestação de serviços urbanos, com a sentença diária de não ter escolha nenhuma em termos de sustento.

Esses trabalhadores estão permanentemente sob ameaça e compõem a parcela mais exposta ao contágio, além, é claro, de quem trabalha diretamente com doentes em hospitais e unidades básicas de saúde. Para esses trabalhadores pobres, seja do primeiro grupo (os trabalhadores de atividades essenciais), seja do segundo (trabalhadores hiperprecarizados), o isolamento não é uma opção. No primeiro caso, isso se deve por serem atividades indispensáveis em uma sociedade em que a tecnologia ainda não dispensou certos postos de trabalho e suas funções. No segundo caso, isso ocorre porque a opção do isolamento não é de fato uma opção se ela implica não trazer o alimento diário para casa. Nessas situações, ficar em casa significa passar fome de fato.

Há um elo intermediário nessa cadeia que é uma parte considerável dos trabalhadores, os quais constituem hoje os chamados plataformizados (ANTUNES, 2020a) ou uberizados (SLEE, 2017). Esses trabalhadores formam um complexo resultado de perdas sucessivas do mercado de trabalho formal, o qual "empurrou" milhares de desempregados ${ }^{23}$ para o "microempreendedorismo individual", muitos deles investindo suas indenizações rescisórias e fundos de garantia na compra do "novo instrumento de trabalho" - bicicletas, equipamentos de proteção individual, motocicletas ou automóveis - para aderir ao modelo inaugurado no ramo de transportes de passageiros e entregas. Porém, também são resultado - e nesse caso o Brasil é um laboratório para importantes constatações de uma situação de permanente exclusão de parcelas de trabalhadores, em geral jovens, negros e moradores de periferias, do mercado de trabalho formal.

Esses jovens, desde cedo, deixam de enxergar a educação e a formação profissional como uma possibilidade de ascensão, por uma dificuldade histórica de inserção de tais grupos em setores formais e qualificados da economia, além da imposição de uma subjetividade neoliberal a que todos estamos expostos e que vai conformar cidadãos que pensam e agem de maneira correspondente ao perfil do sujeito neoliberal, compatível com o governo empresarial, ambos descritos por Dardot e Laval (2016). A ideia da "empresa de si como ethos da autovalorização" (idem, p. 333), da "autonomia" como ambição do trabalho "livre",

[...] transformações no mundo do trabalho materializadas na precarização desse segmento social que alimentam a informalização das economias e, com ela, a adoção do termo "autônomo" como um eufemismo para a nova situação a que está exposto não só o trabalhador urbano, mas também o trabalhador agrícola. Essa "eufemização" faz parte de uma estratégia de atuação do capitalismo "pós-industrial" que envolve novos tipos de propaganda (new marketing) e uma nova psicologia social: o trabalhador

\footnotetext{
${ }^{21}$ cf. Kowarick $(2002,2003)$.

${ }^{22}$ Cavallero e Gago (2020).

${ }^{23}$ Ver Pochmann (2006).
} 
que não tem carteira assinada, direitos trabalhistas e acesso a benefícios sociais, não é informal, é "autônomo"; aquele que possui esses direitos por estar submetido a uma relação de assalariamento, por sua vez, não é mais um empregado (termo carregado de subjetividade), é agora um "colaborador" da empresa; os trabalhadores terceirizados e temporários não são mais subcontratados, mas “cooperativados" ou ainda "parceiros", e assim sucessivamente. Essa ressignificação da economia, no sentido de incutir novo significado aos cargos, funções e papéis sociais, em meio às novas questões do mercado e da sociedade, hipertrofiaram o segmento dos "trabalhadores autônomos". Cada vez mais, se inserem na informalidade quantidades maiores de trabalhadores desempregados, precarizados, (super)explorados, contribuindo para uma banalização da ideia de autonomia (RAMOS; RODRIGUES, 2010, p. 6-7).

Esse mito da flexibilidade da escolha da jornada e da forma do trabalho torna-se um mantra que reproduz a lógica do (auto)convencimento, até mesmo para aqueles que já teriam cumprido com sua parcela de contribuição como força de trabalho ativa. Os trabalhadores idosos, os aposentados formais e aqueles que nunca conseguiram esse direito se tornam alvos de uma incorporação perversa associada a um desprezo sistêmico.

Em se tratando dos trabalhadores que já atingiram a idade para a aposentadoria, mas permanecem ativos no mercado de trabalho formal, informal, plataformizado, uberizado etc., há seguramente um prolongamento da vida ativa por hipossuficiência econômica, e, concomitantemente, torna-se comum o papel de idosos chefiando famílias, de homens e mulheres com renda oriunda de aposentadorias, pensões e auxílios ou que permanecem no mercado de trabalho contribuindo para o sustento dos mais jovens.

Diante da hegemonia da subjetividade neoliberal, a permanência do trabalhador idoso no mercado de trabalho é vista como uma contingência. Ao mesmo tempo, suas limitações e maior vulnerabilidade - à violência, aos acidentes urbanos e, na atualidade da pandemia da Covid-19, ao risco de contaminação com riscos agravantes - não são tratadas como um problema real, como dados a serem considerados para o mercado de trabalho. Contraditória e concomitantemente, esses trabalhadores não são imunes a uma subjetividade etarista que os vê como aqueles que já não interessam à economia, nem como produtivos, nem como consumidores, ou seja, tratar-se-iam de populações descartáveis. Nesse sentido, a assimilação e a reprodução da ideia de que "os idosos são os que mais morrem por complicações da Covid” - consequentemente, a doença não seria um risco social -, de fato reforçam uma interpretação darwinista do risco para a qual os idosos estão a cumprir seu único propósito, que é morrer.

Todos os trabalhadores e trabalhadoras, jovens ou adultos desempregados, aposentados ou não, estão entregues a (já não tão) novas formas de exploração e espoliação pelo trabalho.

A exploração é facilmente identificada e reside na baixíssima remuneração por hora de trabalho em comparação com o lucro dos capitalistas e investidores. Os sites de agenciamento dos trabalhadores indicam rendimentos que variam entre $\mathrm{R} \$ 9$ a $20^{24}$ por hora trabalhada para atividades que vão da entrega de comida e mercado a pé e de bicicleta, por exemplo, até o transporte particular de passageiros com automóvel. Trata-se de uma média bastante baixa, independentemente das atividades, em si mesmas distintas e com diferentes graus de responsabilidades por parte dos envolvidos. É baixa especialmente se comparada ao valor de mercado dessas empresas, tendo em vista o dinheiro por elas movimentado anualmente e sua participação em mercados financeiros globais. A título

${ }^{24}$ Salário (2020). 
de ilustração, a Movile, proprietária da marca $i F o o d$, estimava o valor de mercado da empresa em 2018 em mais de 1 bilhão de dólares ${ }^{25}$, não tendo praticamente nenhum encargo fiscal, trabalhista ou previdenciário.

Já a espoliação reside nos detalhes. Desde a flexibilização de legislações ou mesmo a inexistência delas, como no caso das variadas formas do trabalho por aplicativos, até as mudanças mais recentes que têm resultado em perdas de garantias e direitos ${ }^{26}$ aos trabalhadores são exemplos clássicos, mas longe de serem os únicos. O endividamento em âmbito individual, doméstico e social de maneira ampla - tem sido uma das formas mais eficientes, na atualidade, de drenar recursos dos trabalhadores mais pobres, aquilo que Luci Cavallero e Verónica Gago vêm caracterizando como "exploração financeira da população 'assistida", isto é "um diferencial nas taxas de juros que se aplicam a esses setores, logo que são caracterizados como 'de risco'” (CAVALLERO; GAGO, 2020, p. 39).

Sujeitos a salários ou rendas (no caso dos trabalhadores por conta própria, não assalariados) insuficientes ao sustento das famílias, ou incapazes de garantir acesso a determinados serviços e bens de consumo, muitos trabalhadores e trabalhadoras recorrem à dívida como forma de driblar a falta de recursos imediatos.

É um ponto notável o encadeamento e a superposição das diversas modalidades de endividamento. Por um lado, trata-se de priorizar o pagamento das dívidas "formais", já que o seu descumprimento acarreta em ficar registrado em plataformas de "inabilitação" financeira (como o Veraz na Argentina ou a Serasa no Brasil), que se converte em um impedimento a novos créditos. Para tentar estar em dia com esse tipo de dívidas, muitas vezes se recorre a outro patamar de endividamento: o informal, que compreende uma variada rede de formas usurárias. Esta se caracteriza por duas coisas: taxas de juro ainda mais altas e formas de violência ainda mais fortes frente à inadimplência no pagamento. Assim, uma dívida se paga com mais dívida. Desse modo, conformamse verdadeiras "redes" de dívida, que vão se refinanciando entre si, habilitando níveis diversos de juros, formas de ameaça por descumprimento e distintos cronogramas de vencimento (CAVALLERO; GAGO, 2020, p. 41).

Tal endividamento vem sustentando uma cadeia de consumo e assistência ampla, indo além do crediário de bens duráveis, imóveis e do crédito rotativo e alcançando serviços de primeira necessidade, como tratamentos de saúde, aluguel de imóveis, custeio de educação/qualificação, na forma de pagamento de mensalidades ${ }^{27}$ em cursos técnicos e no ensino superior ${ }^{28}$, ou mesmo o pagamento de outras dívidas.

Some-se a esse quadro os juros historicamente elevados no país ${ }^{29}$, e a drenagem configurada no comprometimento total da renda do trabalhador com custeio de dívidas,

\footnotetext{
${ }^{25}$ Pacheco (2018).

${ }^{26}$ A Reforma Trabalhista (2017) e a Reforma da Previdência (2019) são dois exemplos recentes já citados.

${ }^{27}$ A formação profissional via ensino superior e técnico tem se apresentado como aposta na melhora da qualidade de vida por parte de alguns trabalhadores e, concomitantemente, como um grande filão do mercado da educação privada, a qual tem diversificado seu campo de atuação via mercado financeiro, em um primeiro momento com as estratégias de abertura de capital e inserção no mercado de ações, e depois também via atuação como operador de financiamentos e sistemas de crédito próprios, configurando um bypass das linhas de acessos a crédito via Estado ou instituições financeiras tradicionais. Isso tem contribuído para um quadro de endividamento corrente da população trabalhadora, fruto do crédito pessoal tradicional - cartões, cheque especial, crédito consignado, variados cardápios de empréstimos e financiamentos -, na aquisição de bens duráveis e mercadorias banais, mas também nas novas e variadas opções de acesso aos serviços como saúde e educação, via financeirização das opções no mercado.

${ }^{28} \mathrm{O}$ ensino superior está cada vez mais financeirizado via sistema de crédito educacional (FIES) e por subsídio direto às empresas educacionais (PROUNI), bem como por meio de grupos que têm capital aberto e fundos de investimento no setor da educação (INSTITUTO HUMANITAS UNISINOS, 2021).

${ }^{29}$ Paulo Gala (2019).
} 
da dilapidação de seu escasso patrimônio e, por vezes, da regressão de sua qualidade de vida por incapacidade de arcar com os compromissos financeiros assumidos perfaz um retrato da espoliação da classe trabalhadora na atualidade, catalisador da crescente acumulação na outra ponta da cadeia.

O endividamento das camadas mais pobres da sociedade e o processo mais amplo de financeirização do mercado capitalista se impõem como mais uma faceta do neoliberalismo em curso há algumas décadas. É a subjetivação funcionando como disseminadora da crença de que todos podem ser empreendedores e de que o sucesso econômico individual é uma questão de esforço, resiliência e capacidade de inovação.

Tais argumentos e crenças parecem ter se aprofundado nas situações de crise, em especial na mais recente, causada pela pandemia da Covid-19, pois fazem transcender as imposições objetivas da vida material, as fraquezas e adversidades reais, substituindo-as por uma crença messiânica no sucesso individual. A principal consequência da emergência desse "sujeito neoliberal", conforme Dardot e Laval, é a erosão da noção de cidadania, ou o que Milton Santos vai denominar "cidadania atrofiada".

Em nenhum outro país foram assim contemporâneos e concomitantes processos como a desruralização, as migrações brutais desenraizadoras, a urbanização galopante e concentradora, a expansão do consumo de massa, o crescimento econômico delirante, a concentração da mídia escrita, falada e televisionada, a degradação das escolas, a instalação de um regime repressivo com a supressão dos direitos elementares dos indivíduos, a substituição rápida e brutal, o triunfo, ainda que superficial, de uma filosofia de vida que privilegia os meios materiais e se despreocupa com os aspectos finalistas da existência e entroniza o egoísmo como lei superior, porque é o instrumento da busca da ascensão social. Em lugar do cidadão formou-se um consumidor, que aceita ser chamado de usuário (SANTOS, 2007, p. 25).

É importante destacar que a primeira edição desse texto é de 1987 e já sinaliza, há mais de trinta anos, características e fragilidades tão caras atualmente e agravadas com a crise instalada pela pandemia de 2020 .

\section{A espacialidade da hiperprecarização na pandemia da Covid-19}

Os pobres das cidades são aqueles que não só têm acesso restringido ao consumo de bens e serviços cada vez mais diversificados e sedutores em um mercado que toma todos os espaços e mentes, por não terem renda compatível com tal comportamento, mas também têm limitadas, dentro desse mesmo mercado e dessa mesma sociabilidade, as suas condições mais básicas de existência. Moradia e trabalho nesse contexto socioespacial se definem pela extrema precariedade, condição incompatível com o discurso dominante do "sucesso individual alcançável por todos"; portanto, altamente frustrante.

Para muitos, essa realidade pode ser ainda mais brutal, se considerarmos a interseccionalidade constitutiva do trabalho precário a partir de fatores já mencionados neste texto. Raça, classe e gênero não são dissociáveis quando se pretende falar de trabalho de baixa renda, assim como é inevitável falar de sua espacialidade periférica e seu grau de exposição a riscos ${ }^{30}$ variados, ou seja, em acordo com Souza (2005, p. 192), “a metrópole

${ }^{30} \mathrm{cf}$. Kowarick (2002). 
é, também, cada vez mais, um locus da pobreza e da miséria, assim como, por tabela, da insegurança e da violência”.

A periferia é constituída não só da zona periurbana, a franja da cidade, mas de favelas, ocupações, loteamentos irregulares, incluídos ou não nas áreas centrais. Trata-se, portanto, da

[...] pobreza que se materializa nos espaços segregados, nas periferias precariamente incluídas, nos espaços preenchidos por atividades econômicas subalternas, nas redes de informalidade e precariedade (como o comércio ambulante, os camelôs, os pequenos prestadores de serviços, os vendedores de drogas a varejo, a prostituição, o jogo ilegal etc.), nas paisagens conflitantes produzidas por miséria e riqueza lado a lado, por mundos tão próximos e em alguns sentidos, tão distantes (RAMOS, 2012a, p. 101).

Esses espaços são resultado de uma característica marcante da habitação no Brasil: o déficit habitacional, o qual consiste na quantidade de novas unidades habitacionais necessárias para atender à demanda da população, isto é, àqueles que não têm casa e não podem pagar por uma. É importante ressaltar que nem todos os imóveis regularizados, destinados ou não à moradia, cumprem a sua função, ou seja, servem efetivamente de moradia para alguém. Mas muitos desses imóveis estão vazios há décadas por questões judiciais, processos por dívidas, espólio, penhora etc., ou cumprem, fechados, desocupados e em processo de deterioração, exclusivamente a função de reserva de valor do solo urbano, contribuindo para a especulação imobiliária nas cidades.

Quando falamos em déficit habitacional, significa, em termos práticos, que a falta do acesso à moradia digna vai impelir as pessoas a dar soluções emergenciais ao seu problema concreto que é a falta de um teto. $O$ resultado são os processos de ocupação de terrenos, em sua maioria públicos, para autoconstrução de habitações e a ocupação de imóveis já edificados (em bem menor proporção e, em geral, tão ou mais precários quanto as moradias que são fruto da autoconstrução em favelas, dado o grau de deterioração desses espaços). Neste sentido, se o déficit habitacional sozinho não diz tudo sobre as injustiças sociais, ele, acompanhado do cálculo dos domicílios vagos e recuperados pela União, aponta para o quão desigual é a apropriação do espaço nas cidades do Brasil e em muitos outros lugares do mundo.

No Brasil, o déficit habitacional era de quase 7 milhões de domicílios (cerca de 9\% da população ${ }^{31}$ ) em 2015, dos quais aproximadamente 5 milhões estão em favelas e periferias precárias. Segundo dados do último Censo do IBGE, na cidade de São Paulo, 11\% da população habita esses espaços, enquanto na cidade do Rio de Janeiro esse valor chega a $22 \%$. Não é a maior em termos proporcionais, mas faz do Rio de Janeiro o líder nacional em número absoluto de moradores de favelas. Outras capitais do país também chamam atenção pela proporção, como Salvador, com 33\%, e Belém, com $54 \%$ da população, além de Fortaleza, Recife, Belo Horizonte, Manaus e São Luís, com proporções de 13 a 23\% de moradias em favelas em relação ao total de moradias, segundo dados (já desatualizados) do Censo 2010 do IBGE. No mundo, esse valor vai ao cômputo de 1,6 bilhão de domicílios $^{32}$, o que significa que aproximadamente $25 \%$ da população mundial vive sem infraestruturas, saneamento básico, acesso a serviços públicos essenciais e com escassez de água e de eletricidade.

\footnotetext{
${ }^{31}$ Segundo dados da Fundação João Pinheiro (2015).

${ }^{32}$ Dados da ONU Habitat.
} 
São trabalhadoras e trabalhadores pobres, em sua maioria fora do mercado de trabalho formal, desempenhando atividades precárias, instáveis e mal remuneradas, com inadequação das moradias que afeta decisivamente sua qualidade de vida. Essa inadequação, segundo critérios definidos para finalidade de cálculo do déficit habitacional, está relacionada à precariedade estrutural, à coabitação familiar, ao ônus excessivo com aluguel que compromete a renda familiar e ao adensamento excessivo das unidades habitacionais.

Não se trata de elementos novos ou de uma conjuntura recente. Tais dados não se baseiam em mudanças de metodologia nos levantamentos e estudos. São parte estruturante de nossa sociedade e dizem muito sobre a história da qualidade de vida e do desenvolvimento socioespacial nas cidades brasileiras. Neste sentido, os fatores de natureza socioespacial ou ambiental são elementos centrais para entendermos o agravamento da pandemia e quais são os grupos sociais e os indivíduos mais afetados por esse evento crítico em saúde pública.

É nas periferias, favelas e ocupações urbanas que moram os trabalhadores e trabalhadoras mais expostos ao risco do contágio, em razão de seus tipos de atividade, fortemente dependentes do contato interpessoal; por causa de seu grau de exposição diária, em geral sujeitos ao baixo isolamento em ruas, avenidas, espaços de grande circulação de pessoas e longo tempo de deslocamento em transportes públicos superlotados; por sua baixa capacidade de autoproteção e autocuidado, tendo em vista o custo e o acesso aos requisitos mais simples destas práticas, a higiene pessoal (acesso à água tratada, saneamento básico e sabão) e máscaras de proteção individual. Além disso, tais espaços são predominantemente habitados por pretos $^{33} \mathrm{e}$ indígenas, que correspondem a quase metade dos trabalhadoras e trabalhadores pobres, informais precários, habitantes dos espaços periféricos em comparação aos brancos ${ }^{34}$.

Pretos e indígenas também compõem quase $2 / 3$ dos desempregados e dos subutilizados no mercado de trabalho brasileiro, e a maioria são mulheres chefiando famílias com rendimentos insuficientes ${ }^{35}$. São essas mesmas mulheres as "cuidadoras" em sentido geral, dentro e fora das instituições. São enfermeiras e técnicas em saúde, profissionais de zelo, manutenção e limpeza, empregadas domésticas, operadoras de caixas em supermercados, balconistas em comércios de pequeno porte, professoras nas etapas iniciais da educação. Em geral, elas têm em comum o fato de acumularem a função de mães e chefes de família, o que corrobora a ampliação da carga de trabalho e/ou a redução de rendimentos da família, e, na atualidade pandêmica, estão mais expostas ao risco de contaminação e disseminação entre os familiares.

Delimitando e qualificando os pobres das cidades brasileiras e entendendo sua espacialidade em termos de moradia, atividades, ocupações e circulação urbana, entendemos também que o trabalho não é apenas mais um atributo da vida, desconectado de uma historicidade e uma de espacialidade (material e social). O espaço, em sua totalidade complexa e contraditória, que se (re)produz em formas, funções, processos e estruturas, categorias propostas por Santos (2008) para análise do espaço geográfico, enseja a espacialidade humana como reflexo e como meio e condição social, e não como acessório ou secundário nas relações sociais. Em outras palavras, as relações sociais são relações espaciais.

\footnotetext{
${ }^{33}$ Dos moradores de favelas, $72 \%$ se declaram "negros", segundo a IpeaDATA (1991-2000).

${ }^{34}$ Que são cerca de 35\% nesses mesmos espaços, segundo o Censo do Instituto Brasileiro de Geografia e Estatística (2010).

${ }^{35}$ Segundo o Instituto Brasileiro de Geografia e Estatística (2010), 63\% das famílias comandadas por mulheres negras estão abaixo da linha de pobreza.
} 
A estrutura diz respeito à própria sociedade, sua economia, política e cultura; o processo remete às articulações, ao conjunto de ações que movimenta a estrutura e a transforma permanentemente; a função se refere à redefinição constante das formas em acordo com os processos que comandam a reprodução social - formas essas que são produtos/ criações humanas e se manifestam em diferentes escalaridades.

Uma sociedade capitalista, periférica e subordinada a relações assimétricas de poder em diferentes níveis escalares e institucionais se expressa em uma estrutura profundamente desigual e injusta em termos de direitos e acessos. Consequentemente, as articulações oriundas dessa estrutura serão conservadoras e tendem a reproduzir as injustiças, ou seja, os privilégios e as exclusões em diferentes setores da sociedade, no mercado de trabalho, no direito à moradia, no acesso à justiça etc. Portanto, a cidade como forma, a segregação urbana, a apropriação desigual do espaço e a circulação condicionada a fatores de ordem estrutural ajudam a compreender a (hiper)precariedade do trabalho, a (des)funcionalidade de algumas formas.

$\mathrm{O}$ aprofundamento da crise social sistêmica que vivemos no último ano diz muito para a compreensão desse edifício teórico. $\mathrm{O}$ aumento da pobreza extrema é um dado concreto produzido com/pela pandemia. Segundo a PNAD Covid-19/IBGE, a "população abaixo da linha de pobreza extrema aumentou em todas as regiões brasileiras", assim como a desigualdade, que teve aumento, principalmente, com a redução e a posterior retirada do auxílio emergencial pelo governo federal.

O aumento da população em situação de rua é um dado que sustenta tal afirmação e uma realidade que chama a atenção no país, sobretudo nas capitais e regiões metropolitanas. Tal ampliação já havia sido registrada desde o último estudo publicado pelo IPEA em $2016^{36}$. A atualização desses dados para o período da pandemia ainda é incerta, mas as relações que se estabelecem não apontam para um prognóstico positivo. A publicação de uma pesquisa de percepção recente indica que, para $43 \%$ dos brasileiros, "o número de moradores de rua em suas cidades aumentou no último ano"37.

Como pensar e planejar o isolamento com (auto)proteção para quem não tem casa ou vive a maior parte do tempo na rua? A tendência ao aprofundamento desse quadro desde sempre existente e por si dramático pode conduzir uma parte não desprezível, mas historicamente desprezada e relegada à indigência, à eliminação física.

Trata-se de uma população cujo grau de abandono e exclusão impedem até mesmo o acesso à assistência social e auxílios de emergência; uma população não contada e não identificável cujo autoisolamento imposto pela conjuntura é impossível diante de um heteroisolamento estrutural e, consequentemente, permanente.

\section{Considerações finais}

No Brasil, já ultrapassamos a marca dos 260 mil $^{38}$ mortos pela Covid-19 e pelo descaso do poder público. E a taxa de desocupação se aproxima dos 15\%, o que significa a ausência de trabalho e renda, e não apenas o desemprego formal.

\footnotetext{
${ }^{36}$ O IPEA ressalta que não existem dados consolidados oficiais sobre a população em situação de rua no Brasil, algo que é contornado com a utilização de dados disponibilizados pelos municípios via cadastro único de assistência social, o que, no entanto, gera muitas inconsistências.

${ }^{37}$ Pesquisa realizada pelo Datafolha em dezembro de 2020 (SANT’ANNA, 2020).

${ }^{38}$ Número referente à primeira semana de março de 2021, disponibilizado em https://covid.saude.gov.br/, dados das Secretarias Estaduais de Saúde.
} 
Como já vínhamos apontando desde abril de 2020, repensar o trabalho, o emprego, as necessidades e o consumo será um dos grandes legados da pandemia da Covid-19, o que significa caminhos abertos à reflexão, ainda que balizados por um certo pessimismo quanto aos reais resultados de tal esforço.

Continuamos acreditando que entender os limites de uma economia baseada na exploração e espoliação dos trabalhadores e trabalhadoras, na extração extrema de mais-valia, no endividamento das famílias e no individualismo como antídoto para a crise sistêmica é uma condição relativamente familiar à sociedade brasileira que vem sendo potencializada pelo caos.

O mesmo caos vai expor de forma crescente a pobreza extrema, visível e invisível, materializada, entre outras formas, na população em situação de rua e no trabalho hiperprecarizado; vai expor cada vez mais nossas assimetrias históricas e nossas entranhas. "Não será 'só' o desemprego, a incapacidade de gerar a própria subsistência, o grande choque da pandemia. Será, também, a demarcação clara entre quem vive e quem morre, quem tem como e onde se 'proteger' e quem simplesmente não tem" (RAMOS, 2020). Que a esperança de algum potencial transformador seja nossa utopia.

\section{Referências Bibliográficas}

AGÊNCIA DE NOTÍCIAS. PIB cresce 3,2\% no $4^{\circ}$ tri, mas fecha 2020 com queda de 4,1\%, a maior em 25 anos. 3 mar. 2021. Disponível em: <https://agenciadenoticias.ibge.gov.br/agencia-noticias/2012-agenciade-noticias/noticias/30166-pib-cresce-3-2-no-4-tri-mas-fecha-2020-com-queda-de-4-1-a-maior-em25-anos>. Acesso em: 15 mar. 2021.

ANTUNES, R. Os sentidos do trabalho: ensaio sobre a afirmação e a negação do trabalho. São Paulo: Boitempo, 2001.

ANTUNES, R. A era da informatização e a época da informalização: riqueza e miséria do trabalho no Brasil. In: ANTUNES, R. (Org.). Riqueza e miséria do trabalho no Brasil. São Paulo: Boitempo, 2006a.

ANTUNES, R. Construção e desconstrução da legislação social no Brasil. In: ANTUNES, R. (Org.). Riqueza e miséria do trabalho no Brasil. São Paulo: Boitempo, 2006b.

ANTUNES, R. Dimensões da precarização estrutural do trabalho. In: DRUCK, G.; FRANCO, T. (Org.). A perda da Razão social do trabalho: terceirização e precarização. São Paulo: Boitempo, 2007.

ANTUNES, R. Trabalho intermitente e uberização do trabalho no limiar da indústria 4.0. In: ANTUNES, R. (Org.). Uberização, trabalho digital e indústria 4.0. São Paulo: Boitempo, 2020a.

ANTUNES, R. O privilégio da servidão: o novo proletariado de serviços na era digital. São Paulo: Boitempo, 2020b.

BRAGA, R. A política do precariado: do populismo à hegemonia lulista. São Paulo: Boitempo, 2012.

BRAGA, R. A rebeldia do precariado: trabalho e neoliberalismo no sul global. São Paulo: Boitempo, 2017.

BRASIL. Decreto no 10.316, de 7 de abril de 2020. Regulamenta a Lei no 13.982, de 2 de abril de 2020, que estabelece medidas excepcionais de proteção social a serem adotadas durante o período de enfrentamento da emergência de saúde pública de importância internacional decorrente do coronavírus (covid-19). Diário Oficial da República Federativa do Brasil, Brasília, DF, 7 abr. 2020a. Disponível em: <http:// www.planalto.gov.br/ccivil_03/_ato2019-2022/2020/decreto/D10316.htm>. Acesso em: 15 mar. 2021.

BRASIL. Micro e pequenos empresários contam com linha de crédito durante pandemia. Brasília, $2020 \mathrm{~b}$. Disponível em: <https://www.gov.br/pt-br/noticias/trabalho-e-previdencia/2020/07/micro-e-pequenosempresarios-contam-com-linha-de-credito-durante-pandemia>. Acesso em: 15 mar. 2021.

CAVALLERO, L.; GAGO, V. Extrativismo financeiro: a dívida como uma ofensiva do capital contra os setores subalternos. In: RODRIGUEZ, G. (Org.). O sistema financeiro e o endividamento das mulheres. Rio de Janeiro: Instituto Equit Gênero, Economia e Cidadania Global, 2020.

DARDOT, P.; LAVAL, C. A nova razão do mundo: ensaio sobre a sociedade neoliberal. São Paulo: Boitempo, 2016. 
ESTADÃO. Uma escolha muito difícil. São Paulo, 8 out. 2018. Disponível em: <https://opiniao.estadao. com.br/noticias/geral,uma-escolha-muito-dificil,70002538118>. Acesso em: 15 mar. 2021.

FUNDAÇÃO JOÃO PINHEIRO - FJP. Centro de Estatística e Informações. Déficit habitacional no Brasil 2011-2012. Belo Horizonte: FJP, 2015.

GALA, P. Breve histórico da taxa de juros real no Brasil. 2019. Disponível em: <https://www.paulogala. com.br/breve-historico-da-taxa-de-juros-real-no-brasil-2/>. Acesso em: 5 mar. 2021.

GRAEBER, D. Bullshit jobs, a theory. EUA: Simon \& Schuster, 2019.

GUILLUY, C. O fim da classe média:a fragmentação das elites e o esgotamento de um modelo que já não constrói sociedades. Record, 2020.

HAN, B.-C. O coronavírus de hoje e o mundo de amanhã, segundo o filósofo Byung-Chul Han. El País, 22 mar. 2020. Disponível em: <https://brasil.elpais.com/ideas/2020-03-22/o-coronavirus-de-hoje-e-omundo-de-amanha-segundo-o-filosofo-byung-chul-han.html>. Acesso em: 15 mar. 2021.

INSTITUTO BRASILEIRO DE GEOGRAFIA E ESTATÍSTICA - IBGE. Sinopse do censo demográfico: 2010. Rio de Janeiro: IBGE, 2011.

INSTITUTO BRASILEIRO DE GEOGRAFIA E ESTATÍSTICA - IBGE. Pesquisa Nacional por Amostra de Domicílios (PNAD) contínua. Rio de Janeiro: IBGE, 2020. Disponível em: <https://www.ibge.gov. br/indicadores\#desemprego>. Acesso em: jun. 2021.

INSTITUTO HUMANITAS UNISINOS - IHU. Kroton Educacional: 'Em termos de educação pública nunca experimentamos um inimigo com uma força social tão concentrada como esse’. 2021. Disponível em: <http://www.ihu.unisinos.br/78-noticias/578444-kroton-educacional-em-termos-de-educacaopublica-nunca-experimentamos-um-inimigo-com-uma-forca-social-tao-concentrada-como-esse $>$. Acesso em: 5 mar. 2021.

KOWARICK, L. Capitalismo e marginalidade na América latina. Rio de Janeiro: Paz e Terra, 1975.

KOWARICK, L. Viver em risco: sobre a vulnerabilidade no Brasil urbano. Novos Estudos, São Paulo, v. 63, p. 9-29, 2002.

KOWARICK, L. Sobre a vulnerabilidade socioeconômica e civil: Estados Unidos, França e Brasil. Revista Brasileira de Ciências Sociais, São Paulo, v. 18, n. 51, 2003.

MARTINS, J. S. Exclusão social e a nova desigualdade. São Paulo: Paulus, 1997.

MARTINS, J. S. O cativeiro da terra. São Paulo: Contexto, 2010.

MÉSZÁROS, I. Desemprego e precarização: um grande desafio para a esquerda. In: ANTUNES, R. (Org.). Riqueza e miséria do trabalho no Brasil. São Paulo: Boitempo, 2006.

MONTENEGRO, M. R. Globalização, trabalho e pobreza nas metrópoles brasileiras. São Paulo: Annablume, 2014.

OLIVEIRA, A. U. A longa marcha do campesinato brasileiro: movimentos sociais, conflitos e Reforma Agrária. Estudos Avançados, São Paulo, v. 15, n. 43, p. 185-206, 2001. http://dx.doi.org/10.1590/S010340142001000300015.

OLIVEIRA, A. U. Modo de produção capitalista, agricultura e reforma agrária. São Paulo: FFLCH, 2007.

PACHECO, P. iFood terá R\$ 1,9 bi em investimentos. Estado de Minas, 14 nov. 2018. Disponível em: $<$ https://www.em.com.br/app/noticia/economia/2018/11/14/internas_economia,1005531/ifood-terar-1-9-bi-em-investimentos.shtml>. Acesso em: 4 mar. 2021.

POCHMANN, M. Desempregados do Brasil. In: ANTUNES, R. (Org.). Riqueza e miséria do trabalho no Brasil. São Paulo: Boitempo, 2006.

RAMOS, T. T. As barricadas do hiperprecariado urbano: das transformações no mundo do trabalho à dinâmica sócio-espacial do movimento dos sem-teto no Rio de Janeiro. Tese-Programa de Pós-graduação em Geografia, Universidade Federal do Rio de Janeiro, 2012a.

RAMOS, T. T. Informalidade e hiperprecarização, economia popular urbana e economia solidária. Revista Território Autônomo, [S.l.], v. 1, 2012 b.

RAMOS, T. T. Uma geografia da pobreza urbana: informalidade e precarização do trabalho. Boletim Campineiro de Geografia, Campinas, v. 4, n. 1, 2014.

RAMOS, T. T. Pandemia é pandemia em qualquer lugar: vivendo a crise da Covid-19 de fora dos grandes centros. Espaço e Economia, v. 18, 2020. Disponível em: <http://journals.openedition.org/ espacoeconomia/11406. Acesso em: 9 mar. 2021.

RAMOS, T. T.; RODRIGUES, G. B. Trabalhador autônomo ou 'trabalhador autônomo'? Do o trabalho como prática heterônoma nos espaços de outrem, ao trabalho como prática de resistência e criação de 
espaços insurgentes. In: ENCONTRO NACIONAL DE GEÓGRAFOS, 16., 2010, Porto Alegre. Anais... Porto Alegre: AGB Porto Alegre, 2010.

SALÁRIO. Quanto ganha um entregador do Rappi, iFood, Uber Eats e Loggi. 2021. Disponível em: <https:// www.salario.com.br/quanto-ganha/entregador-rappi-ifood-uber-eats-loggi/>. Acesso em: 4 mar. 2021.

SANT'ANNA, E. Para 43\% dos brasileiros, número de moradores de rua aumentou, Datafolha, 4 jan 2020. Disponível em: <https://www1.folha.uol.com.br/cotidiano/2020/01/para-43-dos-brasileiros-numerode-moradores-de-rua-aumentou.shtml>. Acesso em: 9 mar. 2021.

SANTOS, M. O espaço do cidadão. São Paulo: Edusp, 2007.

SANTOS, M. Espaço e método. São Paulo: Edusp, 2008.

SLEE, T. Uberização: a nova onda do trabalho precarizado. São Paulo: Editora Elefante, 2017.

SOARES, L. T. R. Ajuste neoliberal e desajuste social na América Latina. Petrópolis: Vozes, 2001.

SOUZA, J. Os batalhadores brasileiros: nova classe média ou nova classe trabalhadora? Belo Horizonte: UFMG, 2012.

SOUZA, J. A ralé brasileira: quem é e como vive. São Paulo: Contracorrente, 2018.

SOUZA, M. L. O desafio metropolitano: um estudo sobre a problemática sócio-espacial nas metrópoles brasileiras. Rio de Janeiro: Bertrand Brasil, 2005.

SOUZA, M. L. Fobópole: o medo generalizado e a militarização da questão urbana. Rio de Janeiro: Bertrand Brasil, 2008.

THEBAUD-MONY, A.; DRUCK, G. Terceirização: a erosão dos direitos dos trabalhadores na França e no Brasil. In: DRUCK, G.; RANCO, T. (Org.). A perda da razão social do trabalho: terceirização e precarização. São Paulo: Boitempo, 2007.

VALLADARES, L. Cem anos pensando a pobreza (urbana) no Brasil. In: BOSCHI, R. R. (Org.). A construção do espaço público no Brasil. Rio de Janeiro: Rio Fundo Editora, 1994.

VASAPOLLO, L. O trabalho atípico e a precariedade. São Paulo: Expressão Popular, 2005.

SOBRE A AUTORA

Tatiana Tramontani Ramos; RAMOS, T.T. Professora do Departamento de Geografia da Universidade Federal Fluminense, em Campos dos Goytacazes (UFF-Campos). Vice-coordenadora do Programa de Pós-Graduação em Geografia da UFF-Campos. Coordenadora do Núcleo de Estudos sobre Território e Conflitos Sociais. 


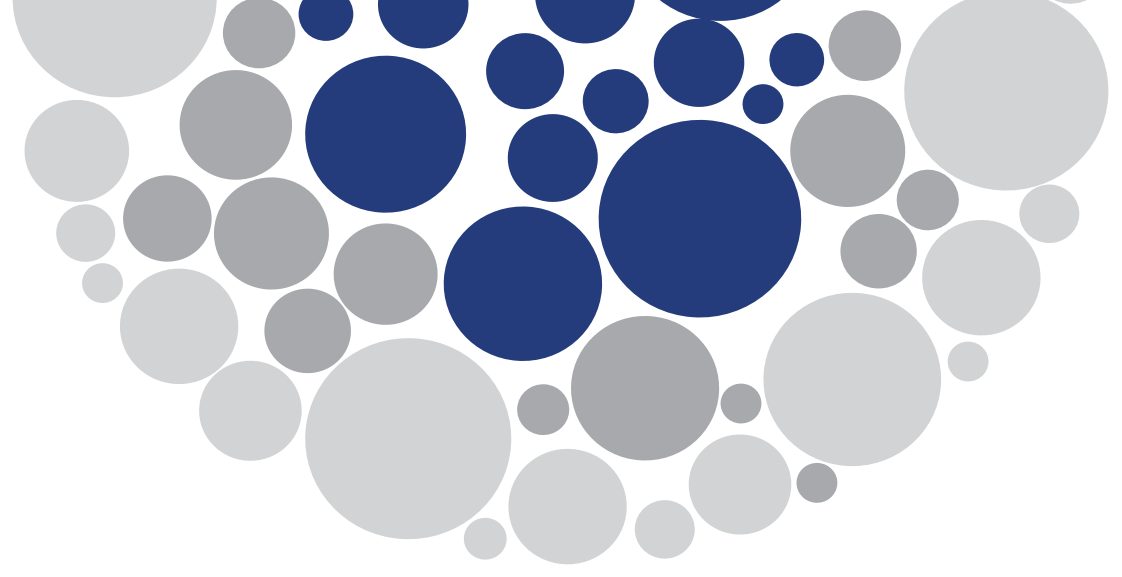

\title{
Meio geográfico, cidade e psicoesfera: da pandemia à sindemia global da Covid-191
}

\author{
Silvana Cristina da Silvaa, Gabrielle Lorena Gomes da Silva ${ }^{b}$, Jenyffer Vidal Oliveirac, \\ Renata Hilel Ribeiro ${ }^{d}$ \\ a Departamento de Geografia, Programa de Pós-graduação em Geografia UFF/Campos dos Goytacazes. \\ E-mail: silvanasilva@id.uff.br

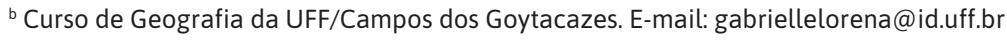 \\ c Programa de Pós-graduação em Geografia UFF/Campos dos Goytacazes. E-mail: jenyffervidal@gmail.com \\ d Programa de Pós-graduação em Geografia UFF/Campos dos Goytacazes. E-mail: renatahilel@id.uff.br
}

\section{Introdução}

O enfrentamento da pandemia causada pelo novo coronavírus trouxe medidas de isolamento social e muitas normatizações para regular as sociabilidades urbanas, gerando muitos conflitos em razão das exigências por mudanças aceleradas dos comportamentos no quotidiano das cidades. Assim, além das frentes de combate que procuram o tratamento adequado aos pacientes infectados e a busca de vacinas eficazes contra a Covid-19, o combate à disseminação da doença envolve outra linha de frente, a que abarca as questões das mudanças dos comportamentos, dos hábitos, do modo de vida nas cidades e do meio geográfico.

Um ano após o decreto de pandemia da Covid- $19^{2}$, tais questões se tornam salutares. Notificações de festas clandestinas, aglomerações em praias e em shoppings, conflitos

\footnotetext{
${ }^{1}$ Este texto resulta do Projeto de Pesquisa, Ensino e Extensão intitulado "Espaço urbano e a pandemia da COVID-19: conflitos e mudanças das sociabilidades urbanas", financiado pelo Edital PROPPI - PROGRAD - PROEX No 04/2020/ UFF 2020, por meio de bolsas concedidas às estudantes participantes do projeto.

2 Este texto foi finalizado no momento em que completamos um ano do decreto da pandemia e quando o Brasil bateu o recorde do número de mortes em um único dia. Em 26 de março de 2021, foram 3.650 mortes, acumulando 307.112 óbitos desde o início da pandemia. Informações disponíveis em: https://covid.saude.gov.br/. Nesse momento, os hospitais de quase todos os estados estão entrando em colapso, com UTIs atingindo 100\% de ocupação e falta de medicamentos para intubação e profissionais de saúde.
} 
constantes pelo não uso de máscaras em lugares públicos, em comércios e em áreas comuns em condomínios passaram a ser constantes, além de manifestações contra lockdown, que abarcam ainda as pressões dos comerciantes e empresários para manutenção das atividades econômicas.

Adicionalmente, a necessidade do trabalho de grande parte da população que não tem como se sustentar, se aderir ao confinamento, evidencia alguns dos sintomas de um processo complexo que a pandemia expôs e aprofundou, mas que tem sua origem no modo de produção, analisado aqui pelo meio geográfico.

Deste modo, fica claro que a pandemia do novo coronavírus, Covid-19, não pode ser examinada de maneira isolada do seu contexto, ou seja, além dos aspectos biológicos do vírus, é preciso considerar que ele encontra as condições históricas e geográficas para sua "origem" e sua acelerada difusão. O meio geográfico atual, denominado técnico-científico-informacional (SANTOS, 2002), é condicionante ativo da pandemia ao constituir-se por uma tecnoesfera - sistemas técnicos e redes de transporte e de comunicação mobilizadores de gigantescos fluxos de pessoas e informações - e por uma psicoesfera - sistema de pensamento, crenças, vontades e paixões (SANTOS, 1992), em que se fabricam as ações -, que transformaram o meio geográfico, ou seja, nosso meio de vida tornou-se mais suscetível a determinadas doenças.

A cidade é a síntese mais bem-acabada desse meio geográfico, uma vez que condensa os sistemas técnicos e expressa a consciência e a inconsciência societária. O modo de vida urbano e as sociabilidades características do período concretizam o meio técnico-científico-informacional. Mais recentemente, as cidades evidenciam como o neoliberalismo reverberou, nas formas, as normas e os comportamentos. O coronavírus encontrou países que privatizaram seus respectivos sistemas de saúde ou cortaram os orçamentos para serviços de atendimento à população. Há ainda um processo de privatização do espaço urbano. Além disso, o modo de vida estressante e a alimentação à base de ultraprocessados contribuem para crescimento de doenças. Assim, a pandemia do coronavírus encontra outras epidemias, como da obesidade, da desnutrição e das mudanças climáticas (CONSELHO FEDERAL DE NUTRICIONISTAS, 2019) ${ }^{3}$. Outrossim, o neoliberalismo produziu um sistema de pensamento que radicalizou o individualismo.

Nesse sentido, realizamos neste texto reflexões sobre a importância da psicoesfera (CARVALHO, 1945; SANTOS, 1988, 1992, 2002, 2008; KAHIL, 1997, 2010) como componente promotor da difusão do coronavírus. Partimos da ideia de que estamos vivendo uma sindemia global da Covid-19, e não apenas uma pandemia (HORTON, 2020), uma vez que vários níveis sinérgicos (biológicos, psicossociais, socioeconômicos etc.) e epidêmicos se encontram e potencializam o contágio, bem como amplificam a letalidade pela Covid-19 em determinados grupos e classes sociais e lugares. A partir do olhar do campo geográfico, apropriamo-nos do conceito de sindemia (SINGER; CLAIR, 2003; LANCET, 2017) e temos como hipótese que a psicoesfera é um elemento sinérgico que pode arrefecer ou agravar a transmissão do vírus ou mesmo piorar as condições dos infectados.

Para tais objetivos, este texto se divide em três seções. A primeira, "Urbanização, modo de vida urbano e cidade: elementos da problemática”, aborda o processo de urbanização

\footnotetext{
Relatório da Comissão The Lancet. A sindemia global da obesidade, desnutrição e mudanças climáticas. 2019. Disponível em: https://alimentandopoliticas.org.br/wp-content/uploads/2019/08/idec-the_lancet-sumario_executivo-baixa.pdf. Acesso em: 25 mar. 2021.
} 
capitalista e evidencia como as cidades catalisam o modo de vida urbano, que é parte da crise sanitária, e expressa o meio geográfico tecnificado, o qual é constitutivo da crise, que é societária, e não apenas sanitária. A segunda seção, "Pandemia, economia urbana e psicoesfera neoliberal", situa a questão do trabalho e o acirramento do neoliberalismo no Brasil, o que revela as principais vítimas da pandemia, os trabalhadores e trabalhadoras hiperprecarizados, que, antes de serem vítimas da pandemia, são vítimas do acirramento do neoliberalismo, o qual é entendido como uma racionalidade que se infiltra no corpo e na alma dos indivíduos. Por fim, a terceira seção, "Meio geográfico e psicoesfera: da pandemia à sindemia global da Covid-19", trabalha o conceito de psicoesfera como parte da sindemia global da Covid-19, pois fica evidente que o sistema de crenças, desejos e afetos é um elemento definidor da exposição ao novo coronavírus e/ou agravamento das condições dos infectados.

\section{Urbanização, modo de vida urbano e cidade: elementos da problemática}

Após a declaração da pandemia do novo coronavírus (SAR-CoV-2), causador da Covid-19, pela Organização Mundial da Saúde (OMS) ${ }^{4}$, foram tomadas uma série de medidas recomendadas pela própria OMS para conter a disseminação da doença, entre as quais o isolamento social e a adoção do uso de máscaras em lugares públicos, que continuam sendo as mais polêmicas e igualmente transformadoras dos comportamentos e das sociabilidades urbanas (Figura 1). Entretanto, o novo coronavírus encontra uma sociedade urbana e conectada à economia globalizada, o que resultou em lugares cada vez mais dependentes das interações globais para realizar as atividades da vida quotidiana.

A intensa urbanização ocorrida no século XX, aprofundada nas décadas recentes do século XXI, expressa o modo de vida adotado por grande parte da humanidade, culminado na formação tendencial de sociedade urbana (LEFEBVRE, 1999). Em outras palavras, a vida com base em aglomerações urbanas e intensas trocas é uma realidade para grande parte da sociedade no mundo contemporâneo. Por um lado, houve avanços no saneamento e da medicina, que garantiram melhores expectativas de vida nas cidades. Por outro lado, a sociedade urbana, juntamente com o processo de globalização, fez com que o potencial de difusão de doenças se tornasse ainda mais potente e rápido. E esse foi o caso da difusão do novo coronavírus, um vírus que coloca no centro do debate a vida nas cidades e o processo de globalização.

Segundo George (1952), a cidade é um fato, menos desenvolvido em algumas civilizações no sul do continente africano, mas que porta uma enorme universalidade. O fato urbano procede de duas grandes séries de causas: da generalização das necessidades de reunir uma parte da população de um país em organismos, com funções específicas em quase

\footnotetext{
4 "A Organização Mundial da Saúde (OMS) declarou, em 30 de janeiro de 2020, que o surto da doença causada pelo novo coronavírus (SAR-CoV-2) constitui uma Emergência de Saúde Pública de Importância Internacional - o mais alto nível de alerta da Organização, conforme previsto no Regulamento Sanitário Internacional. Em 11 de março de 2020, a COVID-19 foi caracterizada pela OMS como uma pandemia" (Organização Pan-Americana da Saúde/ Organização Mundial da Saúde, 2020). Disponível em: https://www.paho.org/bra/index.php?option=com_content\&v $i e w=$ article\&id=6101:covid19\&Itemid=87. Acesso em: 22 jul. 2020 . Completamos um ano de pandemia com algumas vacinas aprovadas e com campanhas de vacinação em curso, mas com pouco avanço, especialmente no Brasil, onde o presidente da República negou as vacinas e foi contra todas as medidas de proteção sanitária, como isolamento social e uso de máscaras.
} 


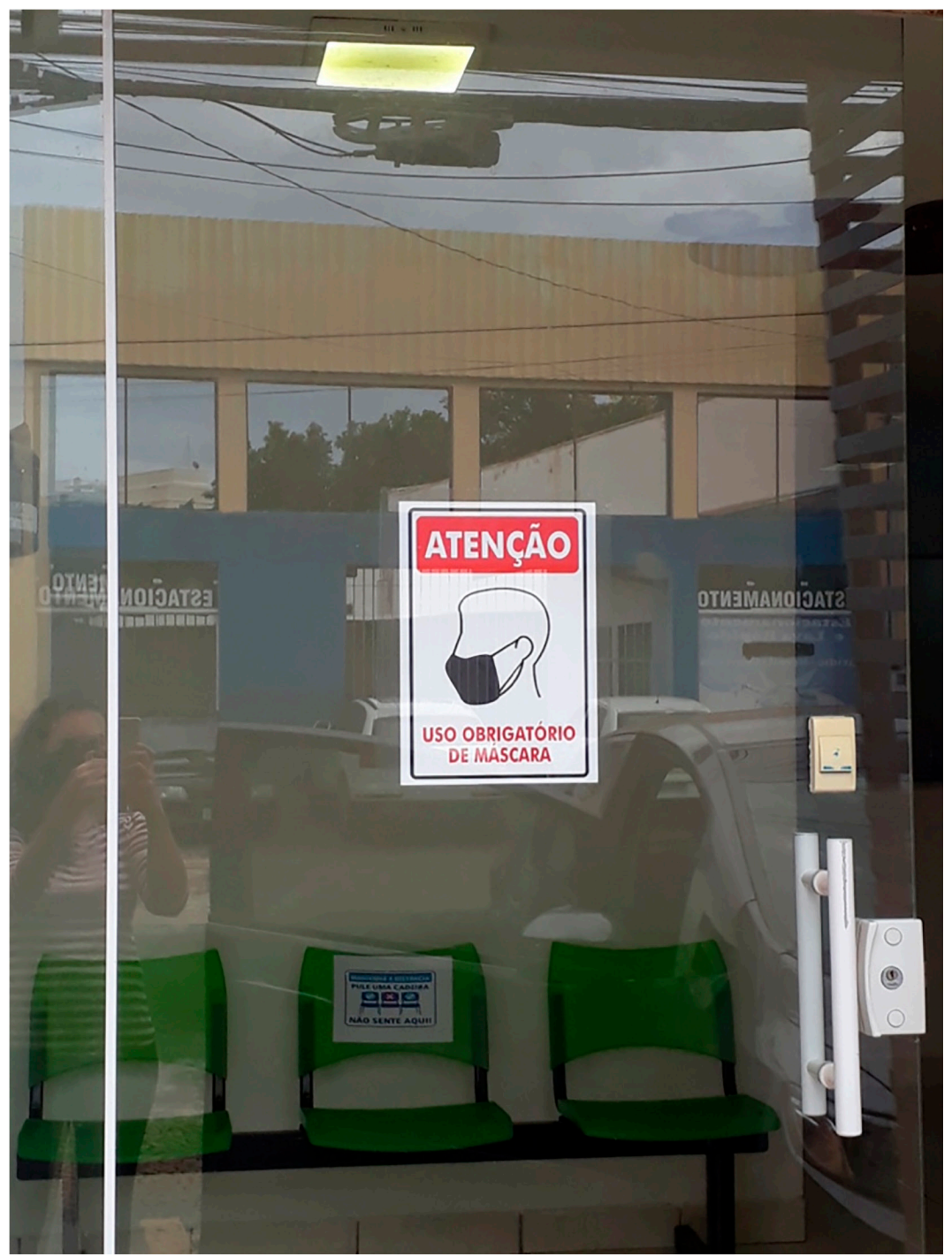

Figura 1 - Uso obrigatório de máscaras em clínica veterinária em Campinas/SP (18/03/2021). Legenda: $O$ uso obrigatório de máscaras em comércio, serviços e lugares públicos é um "gesto de barreira" contra a transmissão do novo coronavírus, o que demandou a criação de legislações municipais e estaduais, além de mudanças de comportamentos, as quais são bastante conflituosas, especialmente causadora de atritos pelos grupos negacionistas da pandemia.

Fonte: foto tirada por Silvana Cristina da Silva (2021).

todas as civilizações, e, sobretudo, em razão da influência da economia capitalista, em que a cidade é o ponto de contato entre a economia industrial e comercial europeia ou americana e a economia nacional, e do desenvolvimento de indústrias, que atrai a concentração da população. Para o autor, as cidades nos países coloniais foram lugares das transações e das especulações. Apesar das desigualdades em termos de poder e das características de cada país, o fato urbano generalizou-se e, com ele, houve a generalização de um modo de vida.

Essas desigualdades são profundas nos países periféricos e semiperiféricos, e as cidades têm, como traço comum, um espaço urbano precário e carente de um sistema de infraestrutura, destacadamente nas periferias. O século XXI é aquele em que a cidade se consolida como o centro do modo de vida da sociedade contemporânea, e, com ele, a cidade condensa os problemas e as contradições do período. 
A cidade no Brasil tem como característica a constituição de espaço urbano pautado na segregação socioespacial (CORRÊA, 1989; CALDEIRA, 2000; SPOSITO; GOÉS, 2013), cuja forma de habitar em condomínio é uma de suas expressões. O shopping center apresenta-se como uma nova forma do comércio na maioria das cidades, ainda que o comércio e os serviços de rua ainda persistam. Por fim, há o processo de periferização da habitação de grande parte das classes trabalhadoras de menor renda para áreas precárias e/ou distantes das áreas centrais (mais bem-dotadas de equipamentos de uso coletivo), no processo que Kowarick (1979) denominou espoliação urbana ${ }^{5}$. Por consequência, o transporte público coletivo tornou-se um ponto nevrálgico e de aumento das desigualdades nas cidades, pois a maioria da população passou a depender do transporte público coletivo para chegar ao trabalho, geralmente concentrado no centro das cidades ou áreas específicas, e para realizar suas atividades quotidianas. A adoção do transporte individual é proibitiva para grande parte da população ou acessível via endividamento, o que gera grandes disparidades entre classe média e elite com relação ao transporte urbano.

A cidade é, por definição, lugar da concentração, da aglomeração, do mercado e de intensas interações, sejam sociais, econômicas, culturais e socioespaciais. Como afirma Sennett (2018), as cidades como aglomerações compõem-se da ville e da cité. A primeira é definida como built environment (ambiente construído), e a segunda, como um tipo de consciência (coletiva) do lugar, constituída por novas formas de viver coletivamente, a cidadania. Em outras palavras, trata-se de uma mentalidade, por isso a ideia de ville é insuficiente. Assim, o autor reflete sobre a consideração da substância humana que compõe a cité, as multidões. Então, a cidade é uma forma densa da substância humana que se relaciona com a forma urbana.

Nesse sentido, Santos (2008) explica que o espaço geográfico é composto por uma tecnoesfera, uma materialidade, e por um sistema de ações, alimentado pela psicoesfera, isto é, a tecnoesfera compõe-se por um sistema de objetos e a psicoesfera faz referência ao sistema de crenças, desejos, esperanças, hábitos, vontades que inspiram comportamentos filosóficos e práticos (SANTOS, 1992). Ambos são indissociáveis, mas a separação se faz necessária para fins analíticos. A psicoesfera antecede a tecnoesfera, embora esta última seja a materialização da primeira e condicionadora dos comportamentos sociais. Dessa maneira, as medidas de isolamento e as novas exigências de comportamento nos espaços públicos e coletivos trouxeram conflitos e demandam ainda entendimento. Uma vez que a cidade possui uma forma, uma mentalidade, um espírito, as mudanças drásticas enfrentam a inércia-dinâmica da forma e, ao mesmo tempo, encontram um sistema de crenças, afetividades e hábitos que podem resistir às transformações ou aceitá-las mais facilmente a depender dos lugares, isto é, a preservação da vida dos mais vulneráveis passa inexoravelmente pelas medidas de contenção da doença, que são concernentes à tecnoesfera e à psicoesfera.

Em resumo, diante desse contexto, a implementação do isolamento social, a recomendação e/ou a obrigatoriedade do uso de máscaras em lugares públicos e de evitar as concentração de pessoas, bem como medidas de distanciamento mínimo, colocaram em evidência os problemas do modo de vida urbano diante de um vírus extremamente

\footnotetext{
${ }^{5} \mathrm{O}$ autor define a espoliação urbana como o processo de "somatória de extorsões que se opera através da inexistência ou precariedade dos serviços de consumo coletivos que se apresentam como socialmente necessários em relação aos níveis de subsistência e que agudizam ainda mais a dilapidação que se realiza no âmbito das relações de trabalho" (p. 59).
} 
contagioso, com conflitos que passam a ser vivenciados nos lares, bairros, condomínios, praças, comércios e colocam em xeque o modelo da cidade capitalista contemporânea, a qual é a condensação do meio geográfico, altamente permeado pela psicoesfera neoliberal.

\section{Pandemia, economia urbana e psicoesfera neoliberal}

As cenas do confinamento em massa em razão da pandemia da Covid-19 geraram imagens raras das cidades no mundo com ruas vazias e populações interagindo pelas janelas e varandas de suas respectivas residências. Novos sistemas de interações sociais foram acelerados, como sistemas de compras pela internet e por aplicativos (Figura 2). Esse talvez seja um dos aspectos mais radicais das mudanças impostas à vida urbana. Assim, coloca-se em evidência como o modo de vida urbano está sendo ameaçado pela pandemia e, ao mesmo tempo, como novas formas de exploração e acumulação surgem ou se aprofundam na crise sanitária.

A urbanização nos países periféricos apresenta como traço a extrema desigualdade e a pobreza urbana (SANTOS, 1965, 2003), que foram agravadas com as políticas de austeridade e neoliberalizantes dos últimos quarenta anos. Segundo Harvey (2008), o neoliberalismo é uma teoria das práticas político-econômicas que considera que o bem-estar humano pode ser alcançado por meio das liberdades e das capacidades empreendedoras dos indivíduos. Ao Estado apenas caberia liberar essas capacidades e criar uma estrutura institucional e jurídica para garantir o direito à propriedade privada, o livre mercado e o livre-comércio. Harvey (2008) acrescenta que, sobretudo, caberia ao Estado as funções de defesa, militar e de polícia para garantir as liberdades de mercado.

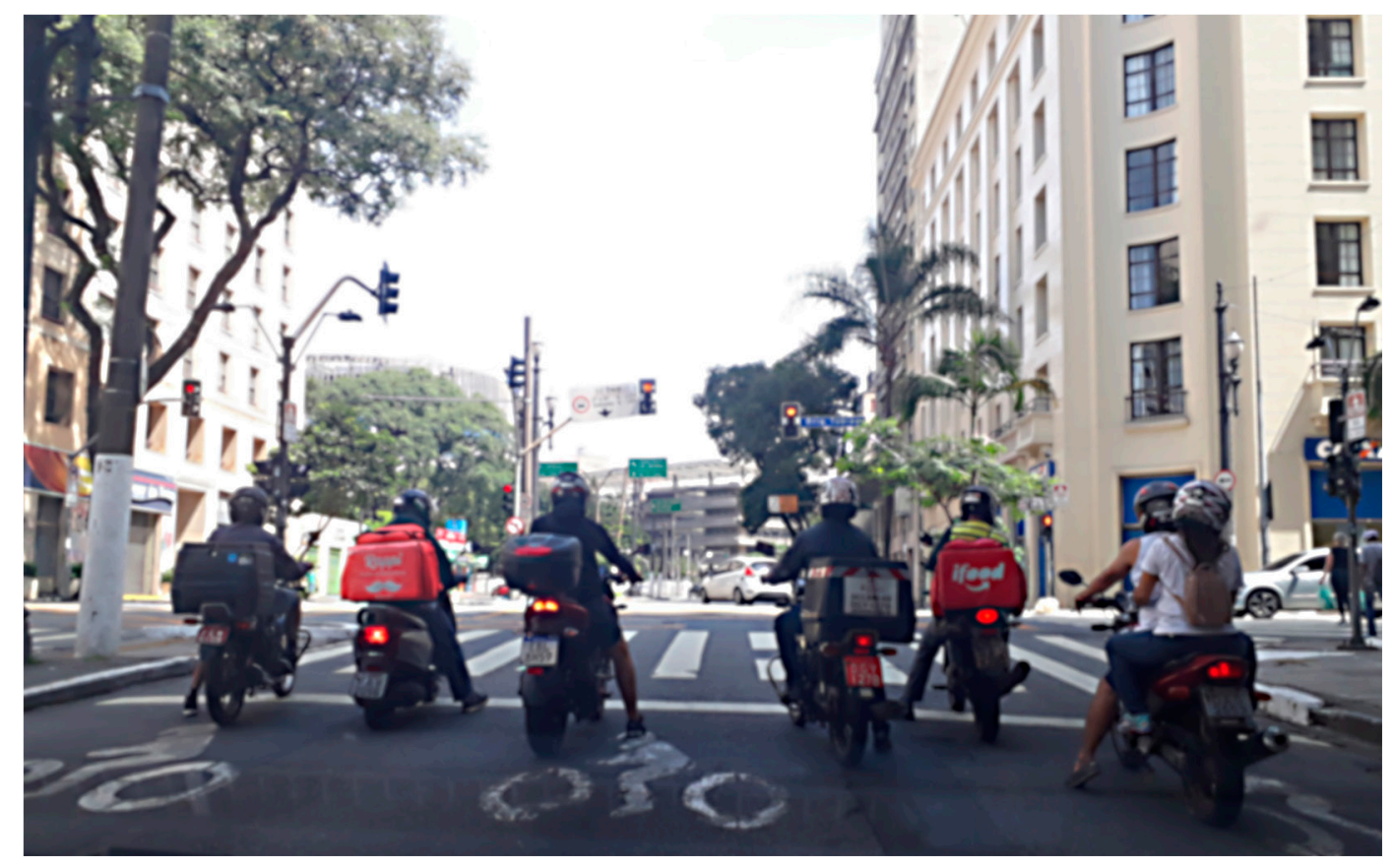

Figura 2 - Entregadores e plataformas digitais na pandemia, São Paulo (20/03/2021). Legenda: Entregadores vinculados às plataformas digitais e/ou autônomos garantem a circulação de mercadorias e a efetivação do comércio no primeiro sábado após o decreto de fase emergencial no estado de São Paulo.

Fonte: foto tirada por Silvana Cristina da Silva (2021). 
Nos anos 1990 e início dos anos 2000, especialmente no governo do então presidente Fernando Henrique Cardoso (1995-2003), do Partido da Social Democracia Brasileira (PSDB), houve a efetivação de um grande programa de privatizações, com destaque para a venda do setor elétrico brasileiro, das telecomunicações e das companhias siderúrgicas e de parte da rede bancária. A agenda neoliberal e privatizante foi retomada em 2016, quando ocorreu o impeachment da então presidente Dilma Rousseff (2011-2016), do Partido dos Trabalhadores (PT). Houve a aprovação da lei conhecida como "Lei do Teto dos Gastos Públicos", que congelou por vinte anos o orçamento público, e a instituição de um novo regime fiscal em 2016, no governo de Michel Temer (2016-2018), do Partido Movimento Democrático Brasileiro (MDB) ${ }^{6}$. Trata-se de um regime austero de congelamento que ataca os serviços públicos, especialmente de atendimento à população. Também houve a aprovação da flexibilização das Consolidação das Leis Trabalhistas (CLT) em 2017, em que houve perdas de direitos dos trabalhadores ao abrir a possibilidade de negociação entre os patrões e empregados, além de outras modificações ${ }^{7}$. A reforma da previdência social é mais uma das reformas radicais que retirou direitos dos trabalhadores e trabalhadoras ao ampliar o tempo de contribuição e a idade mínima para a aposentadoria, aprovada em 2019, pelo governo do presidente Jair Bolsonaro (2019-atual, sem partido) ${ }^{8}$. Assim, a reforma trabalhista institui a precarização na forma da lei, e a reforma previdenciária torna quase inacessível o direito à aposentadoria para grande parte da população diante da estrutura da economia urbana brasileira.

As medidas de isolamento social desencadeadas pela crise sanitária do novo coronavírus tiveram repercussões limitadas em razão de a maioria da população brasileira depender de trabalhos intermitentes e precários, ou seja, de trabalhos gerados no circuito inferior da economia urbana (SANTOS, 2002) ${ }^{9}$. Não trabalhar significa para uma parte da população não ter meios de subsistência. Conforme aponta Boaventura de Sousa Santos (2020), isso é parte da cruel pedagogia do vírus.

Como aponta Santos (2020), mulheres cujas profissões se relacionam com o cuidar (enfermeiras, trabalhadoras do lar, domésticas, diaristas, cuidadoras) foram as primeiras a serem afetadas. Nesse sentido, é emblemático que a primeira morte por Covid-19 no Brasil tenha sido de uma empregada doméstica, moradora de um município vizinho à cidade do Rio de Janeiro, trabalhadora de uma residência no Leblon, que foi contaminada na casa da patroa recém-chegada de uma viagem à Itália, área foco da doença ${ }^{10}$. Os trabalhadores precários, denominados informais, não podem deixar de trabalhar (Figura 3), e, segundo, dados do IBGE, no Brasil quase $50 \%$ da população economicamente ativa está

${ }^{6}$ Emenda Constitucional no 95, de 15 de dezembro de 2016. Disponível em: http://www.planalto.gov.br/ccivil_03/ constituicao/emendas/emc/emc95.htm. Acesso em: 15 mar. 2021.

7 Lei Federal no 13.467, de 13 de julho de 2017. Disponível em: http://www.planalto.gov.br/ccivil_03/_ato2015-2018/2017/ lei/113467.htm. Acesso em: 15 mar. 2021.

${ }^{8}$ Emenda Constitucional no 103, de 12 de novembro de 2019. Disponível em: http://www.planalto.gov.br/ccivil_03/ constituicao/emendas/emc/emc103.htm. Acesso em: 15 mar. 2021.

9 O circuito inferior compreende as formas utilizadas pela população pobre (economicamente) de gerar renda a partir de atividades de organização simples, que dependem de mão de obra intensiva e pouco (ou nenhum) capital. O circuito superior revela-se pela atuação das grandes empresas com uso de capital intensivo, tecnologias inovadoras e organização do trabalho rígida. Esses dois circuitos formam o subsistema urbano nos países periféricos. O primeiro estabelece relações de dependência, complementaridade ou mesmo concorrência com relação ao segundo. Contudo, ambos os circuitos são parte de um único sistema econômico urbano, em que não se cabe dualismo.

${ }^{10}$ Informações disponíveis em: https://noticias.uol.com.br/saude/ultimas-noticias/redacao/2020/03/19/primeira-vitimado-rj-era-domestica-e-pegou-coronavirus-da-patroa.htm. Acesso em: 25 mar. 2020. 


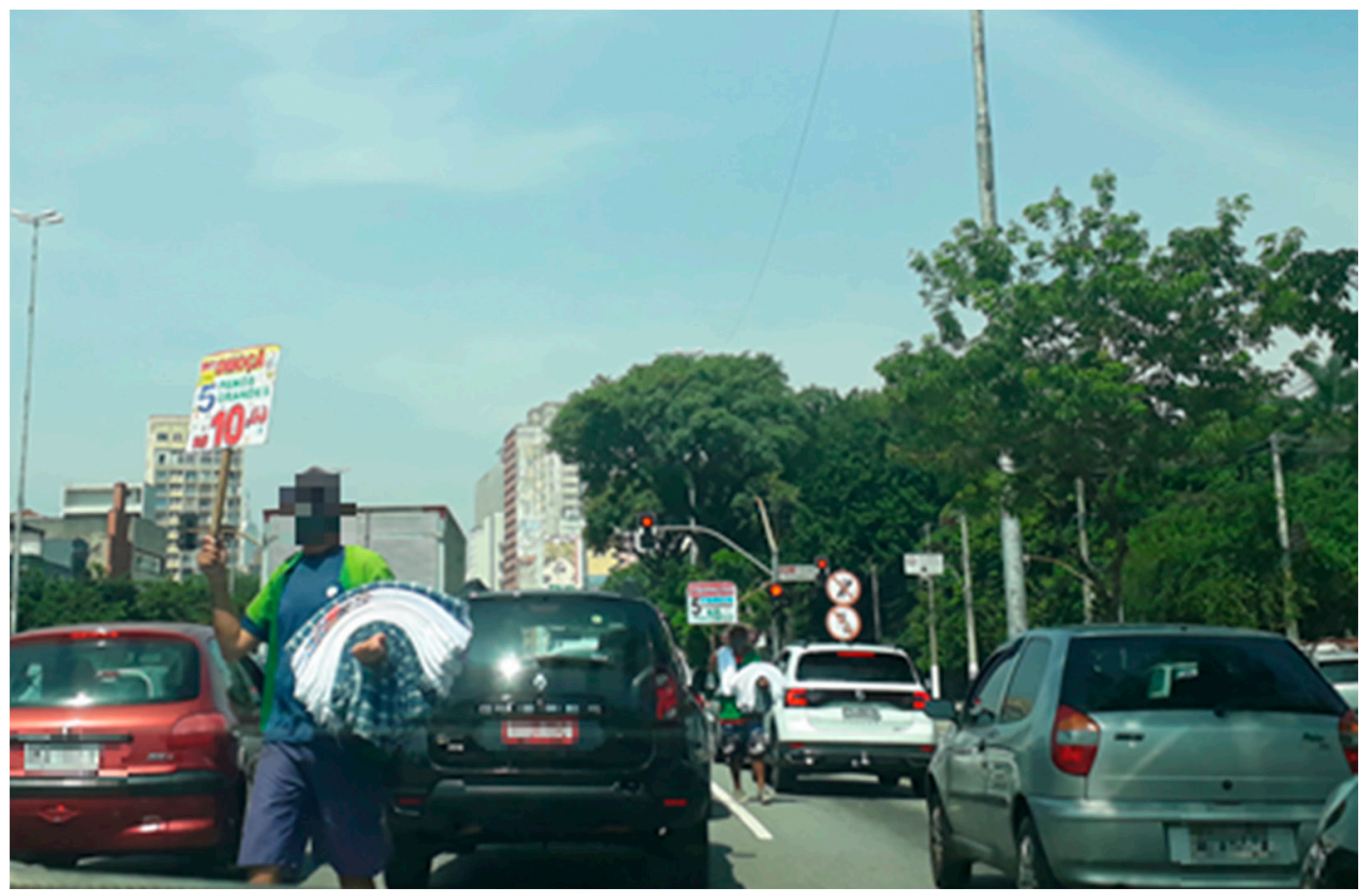

Figura 3 - Vendedores de panos de limpeza em um semáforo em São Paulo (20/03/2021). Legenda: Nos semáforos de grande parte das cidades, multiplicam-se vendedores/as de panos, guardanapos, balas e toda sorte de objetos. Trata-se de trabalhadores/as do circuito inferior da economia urbana, que têm sua situação agravada com a pandemia. Fonte: foto tirada por Silvana Cristina da Silva (2021).

desempregada ou vive de atividades intermitentes e informais (INSTITUTO BRASILEIRO DE GEOGRAFIA E ESTATÍSTICA, 2020). Esse número piorou com a persistência da pandemia por um ano e sem perspectivas de mudanças no quadro no horizonte próximo. A falta de saneamento e a superdensidade demográfica de habitações em favelas e bairros populares, além da necessidade de transporte público coletivo, acabam implicando a disseminação do vírus. Tais problemas antecedem à pandemia e foram profundamente agravados com ela (SANTOS, 2020).

Outro elemento que evidencia o meio geográfico como fator sinérgico com a pandemia é o transporte. Como já mostramos, as cidades brasileiras concretizam no espaço urbano as desigualdades e o processo de periferização de parte das classes trabalhadoras, especialmente de baixa renda e que trabalham no circuito inferior da economia urbana. São essas classes sociais as mais afetadas pela pandemia, uma vez que o uso do transporte público se tornou um fator de risco do contágio, além da preponderância de os grupos mais atingidos serem os trabalhadores "autônomos" e informais, mulheres e negros (LACERDA, 2020) ${ }^{11}$.

A distribuição dos equipamentos coletivos de saúde, como hospitais, postos de saúde, número de médicos, enfermeiros, bem como a disponibilidade de leitos, é outro aspecto da tecnoesfera do espaço geográfico reveladora da neoliberalização do espaço e das desigualdades territoriais. No que concerne às UTIs, equipamento de

${ }^{11}$ Vide a pesquisa da UNIFESP, coordenada pelo professor Kazuo Nakano, relatada na reportagem LACERDA, N. Covid mata mais entre trabalhadores que dependem do transporte coletivo. Brasil de Fato, São Paulo, 18 ago. 2020. Disponível em: <https://www.brasildefato.com.br/2020/08/18/covid-mata-mais-entre-trabalhadores-que-dependemdo-transporte-coletivo>. Acesso em: 15 jan. 2021. 
saúde emblemático para a pandemia da Covid-19, as metrópoles e as grandes cidades, em geral, têm a maior disponibilidade de leitos, enquanto as cidades pequenas são as que menos possuem disponibilidades de leitos, pela própria organização do Sistema Único de Saúde (SUS), que corresponde à rede e hierarquia urbanas. Isso implicou o atendimento aos infectados em estado grave. Desse modo, evidencia-se a cidadania como um elemento territorial, analisada aqui pela disponibilidade dos equipamentos de saúde para atendimento da Covid-19.

Segundo Guimarães (2020), “[...] apenas 421 dos mais de 5.570 municípios contavam com a estrutura necessária para atender pacientes graves em meio à pandemia. E a maior parte deles está localizada nas capitais e regiões metropolitanas"12. Além disso, há enormes desigualdades na distribuição dos leitos de UTIs entre o sistema público e o sistema privado. O primeiro conta com 13,6 leitos para cada 100 mil habitantes, enquanto o segundo, 62,6 para cada 100 mil habitantes - vale destacar que cerca de $25 \%$ da população tem plano de saúde privado. A situação do SUS, além das insuficiências históricas pela falta de recursos e cortes orçamentários, foi afetada pelas políticas neoliberais, que preconizam a retirada do Estado, inclusive das atividades essenciais, cedendo-as ao setor privado. Assim, o neoliberalismo contribuiu para a crise sanitária. No entanto, a fabricação dos consensos com relação à defesa dos modelos de planejamento e gestão públicos neoliberais passa pela disputa da esfera dos espíritos.

Por isso, adicionamos à interação sinérgica geográfica da pandemia a psicoesfera, a qual é orientadora dos comportamentos e das sociabilidades que interagem e engendram o meio geográfico. O neoliberalismo como racionalidade política preconiza a liberdade individual acima de tudo, a competição como princípio de vida e o empreendedorismo como ação individual para atingir o sucesso (DARDOT; LAVAL, 2016). Deste modo, o neoliberalismo não é apenas uma doutrina econômica que defende o livre mercado e a não intervenção do Estado na economia. Para os autores, trata-se de uma racionalidade que foi introjetada na sociedade, buscando que os indivíduos ajam e atuem como se fossem empresas sob o fundamento do empreendedorismo de massa. Então, para Dardot e Laval (2016), o neoliberalismo é a razão do capitalismo contemporâneo.

A adoção do confinamento, as medidas de distanciamento mínimo em comércios, a obrigatoriedade do uso de máscaras, as proibições do uso de áreas comuns dos condomínios, entre outras regras, vêm evidenciando um choque nas sociabilidades urbanas estabelecidas. Estas dizem respeito às interações recíprocas entre os indivíduos, uma rede empírica de relações humanas operativas em um dado tempo e espaço, e formas abstratas relacionais das quais os indivíduos fazem parte, formando a sociedade. As "sociações" foram o núcleo básico do complexo de indivíduos socializados, conforme afirma Frúgoli (2007), apoiando-se em Simmel (1987). À medida que foram demandadas mudanças da maneira de interagir entre os indivíduos para conter a pandemia, houve um confronto com as sociabilidades urbanas estabelecidas, inclusive acrescidas das sociabilidades digitais, em especial aquelas redes difusoras de fake news, negacionistas da existência da pandemia ou minimizadora dos danos que ela poderia causar aos infectados e ao país. Portanto, a psicoesfera neoliberal corroborou para que as redes negacionistas ganhassem vida.

\footnotetext{
${ }^{12}$ GUIMARÃES, C. Especialistas analisam a disponibilidade de leitos no país e discutem possibilidades. Fiocruz. 08 mai. 2020. Especial COVID-19. Disponível em <https://portal.fiocruz.br/noticia/especialistas-analisam-disponibilidadede-leitos-no-pais-e-discutem-possibilidades>. Acesso em: 23 mar. 2021.
} 
A psicoesfera é elemento central para o combate à pandemia. Se as pessoas foram convencidas de que não há o que ser feito e não tomam providências com relação aos gestos de barreira, os sistemas técnicos mais avançados de atendimento não serão suficientes. Por isso, a camada psicossocial faz parte da construção do meio geográfico, cujas cidades são as sínteses do nosso modo de vida no atual período.

\section{Meio geográfico e psicoesfera: da pandemia à sindemia global da Covid-19}

As preocupações do campo geográfico com relação à difusão de doenças não são recentes. A tecnificação do meio geográfico implicou um modo de vida racionalizado. As doenças, epidemias, endemias e pandemias mantêm uma relação orgânica com o meio geográfico. Assim, a psicoesfera faz parte do processo pandêmico e está articulada com a sindemia global da Covid-19.

Sobre a relação entre o meio geográfico e o avanço das doenças, interessa-nos, especialmente, a abordagem de Monbeig (1998), em seu livro Pioneiros e Fazendeiros do Estado de São Paulo, em que o autor apresenta e analisa a história da "Marcha para Oeste", interiorização do território brasileiro. Ele dedica um capítulo para falar da "situação sanitária do mundo pioneiro", definido como sendo "as moléstias ligadas aos gêneros de vida”. Nas palavras de Monbeig (1998, p. 327): "O que nos interessa não é tanto a ação ecológica dos pioneiros, mas o reconhecimento da estreita relação que os seus modos de vida têm com as afecções que os atacam", ou seja, doença e saúde caminham juntas com evolução do meio geográfico. À medida que a ocupação do interior de São Paulo foi ocorrendo, com desmatamento das florestas, ocupação dos vales pelo gado, instalação de cidades seguindo a linha dos trilhos, as doenças da "Marcha para o Oeste" foram se instalando.

Entre as doenças endêmicas, Monbeig (1998) destaca as decorrentes da derrubada das florestas: a febre amarela, registrada em 1935 na franja de ocupação, tornando-se uma epidemia nos anos seguintes e devastando o estado de São Paulo; a leishmaniose, denominada flebotomíneo e propagada pelo mosquito-palha, que também se tornou uma doença da franja pioneira. O autor destaca ainda outras moléstias, como a ancilostomose (amarelão), que causa anemia e tracoma, e afecções de origem alimentar e associadas à pobreza.

Horácio de Sousa (2014), em obra comemorativa ao centenário de Campos dos Goytacazes, traz um capítulo para falar das epidemias, destacando que a cidade era "pestilenta": "tendo muitas endemias, certamente causadas pelos vários pântanos lagôas, enxarcamento, ausencia de canalização das águas servidas e esgoto para as materiais fecaes, pois tudo ia para as baixadas do Rocio, da Bacia e para o rio, infeccionando aquelles logares" (SOUSA, 2014, p. 361) ${ }^{13}$.

O autor ressalta, primeiramente, a "Grande Epidemia de 1855, Cólera Morbus" (eclodiu em Paris em 1832, com mortalidade de 50\%, de forma rápida e degradante). Foram tomadas algumas medidas, como fechamento dos templos, mas houve problemas de abastecimento, sendo os mais afetados os escravizados. A cólera fez cerca de 2.330 vítimas em 1855 e quase 1.000 mortes (a maior parte de escravizados). Depois, o autor aponta a

${ }^{13}$ Foi mantida a grafia original. 
febre amarela, que assombrou a cidade em 1850, durou até julho de 1851 e reapareceu em 1857. Além disso, Sousa (2014) relata as febres reinantes, denominadas também febres da quadra, que eram comuns e atacavam sempre entre março-abril; as epidemias de varíola, que acometeram a cidade em vários anos $(1838,1862,1863,1865,1866,1867,1872,1873$, 1879 e seguiu nos anos seguintes); a peste bubônica (primeiro caso registrado em 1895).

De fato, o que se coloca é que as epidemias são historicamente datadas e se inscrevem geograficamente. Já o meio geográfico é entendido como híbrido dos sistemas de objetos técnicos e naturais e de ação humana (SANTOS, 2002); logo, constitui parte do contexto da disseminação das epidemias e pandemias.

Assim, chegamos a um elemento central da análise que implicou o desencadeamento da pandemia da Covid-19: o vírus nasce como um problema integrado ao meio geográfico, isto é, engendrado pelo nosso modo de vida. É um vírus da globalização e da sociedade capitalista moderna, cujo meio geográfico tem papel ativo.

Há elementos relevantes que se combinam com a própria ecologia das doenças, com a existência de fatores sinérgicos que potencializam as forças das epidemias e atingem grupos sociais distintamente: trata-se das sindemias, já teorizadas por Singer e Clair (2003). Para os autores, a sindemia define-se pela interação sinérgica de doenças coexistentes, fatores biológicos e fatores ambientais, que podem piorar doenças nas populações, isto é, a sindemia diz respeito ao entrelaçamento de doenças infecciosas com as condições sociais e biopsicológicas resultantes de disparidades e violência estrutural. Logo, uma compreensão sindêmica da doença refere-se:

[...] a uma estrutura conceitual para a compreensão das doenças ou condições de saúde que surgem nas populações e que são agravadas pela situação social, econômica, ambiental, política em que uma população está imersa. Uma sindemia, ou epidemia sinérgica, é mais do que um jogo de palavras ou um sinônimo para comorbidades. A característica distintiva de uma sindemia é a presença de dois ou mais estados de doença que interagem adversamente uns aos outros, afetando negativamente e mutuamente o curso da trajetória de cada doença. O que provoca o aumento da vulnerabilidade, que são mais deletérias quando experimentadas iniquidades [...]. Talvez a característica mais exclusiva da sindemia seria a abordagem para compreender vários estados de doença e a forma como eles se agrupam com ênfase em situações circunstanciais em que os indivíduos vivem. Em outras palavras, os fatores sindêmicos dependem fundamentalmente do contexto. Quando usado na década de 1990 pelo médico antropólogo Merrill Singer, a noção de sindemia foi usada para descrever as interações entre o abuso de substâncias, violência e AIDS (SAVA) ${ }^{14}$, que se tornou uma verdadeira crise de saúde em Hartford, CT, EUA. Enquanto investigavam a prevenção do HIV em usuários de drogas, pesquisadores observaram uma constelação de elementos que afetavam o risco, fatores estruturais como falta de habitação e pobreza, e aspectos sociais, como estigma e falta de sistemas de apoio - todos reforçando a carga de doenças (LANCET, 2017, p. 881) $)^{15}$.

Singer e Clair (2003, p. 424) destacam que "o conceito de sindemia pode começar com uma avaliação de sua expressão em níveis populacional, biológico e contexto social". A pandemia do coronavírus tem evidenciado os fatores sinérgicos entre as várias doenças que afetam as condições do infectado e também as taxas de letalidade. Doenças preexistentes, ou as denominadas comorbidades, interagem sinergicamente com o

\footnotetext{
${ }^{14}$ Acrônimo para substâncias abusivas, violência e AIDS, em inglês.

15 Tradução livre.
} 
vírus e agravam o estado do infectado, como o quadro de diabetes, obesidade, pressão alta e doenças cardiovasculares, entre outros fatores de risco (por exemplo, a idade). No entanto, o contexto social, analisado aqui como meio geográfico, é relevante para o desencadeamento da doença e sua difusão em determinados grupos sociais e lugares. Daí partilhamos da ideia de que estamos vivendo uma sindemia global do coronavírus, uma vez que a Covid-19 está relacionada a diversos fatores sinérgicos que potencializam as epidemias já existentes, como má alimentação, desnutrição e mudanças climáticas (HORTON, 2020). Portanto, um dos fatores sinérgicos é o meio geográfico.

Expliquemos: entendemos o espaço geográfico como um conjunto indissociável de objetos (artificias e naturais) e ações, um híbrido de formas e ações. Estas últimas dizem respeito às normas (regras, normas jurídicas e normas sociais), moral pública e privada, visões de mundo e da política que agem sob uma cultura. A ação tem como fonte um sistema consciente e racional, combinado com um sistema psíquico inconsciente, construído pelo processo de individuação e transindividuação. Esses processos vêm sendo direcionados pelo capital para proletarizar o espírito dos trabalhadores, e não apenas o corpo (STIEGLER, $2008)^{16}$. Esse aparelho psíquico é analisado aqui por meio da psicoesfera, ou seja, a esfera "das crenças, desejos, vontades e hábitos que inspiram comportamentos filosóficos e práticos, as relações interpessoais e a comunhão com o Universo" (SANTOS, 1992, p. 3). O par dialético tecnoesfera e psicoesfera expressa o espaço geográfico contemporâneo, denominado por Santos (2002) como meio técnico-científico-informacional, a cara geográfica do processo de globalização.

Esse meio geográfico é gerador de uma geografia das redes de transporte e comunicação. Instituída sob a égide do mercado, ela impôs a aceleração dos fluxos materiais e imateriais. Logo, os espaços da economia global foram os inicialmente mais afetados e tornaram-se centros irradiadores do vírus. Nova Iorque (Estados Unidos), Paris (França) e Londres (Inglaterra), cidades globais (SASSEN, 2001), passaram a ser rapidamente centros de transmissão e concentração do número de óbitos pela doença, assim como Bergamo (Itália) e Wuhan (China), centros industriais da economia globalizada, foram epicentros da pandemia. A globalização é um fator sinérgico que tornou alguns lugares mais susceptíveis que outros à doença, uma vez que a densidade da geografia das redes é um elemento da transmissão comunitária. Trata-se, portanto, de um dado advindo da tecnoesfera do meio geográfico contemporâneo.

Com o individualismo exacerbado preconizado pela psicoesfera neoliberal e a retirada do Estado de suas funções, temos resultados catastróficos na formação socioespacial brasileira. O governo brasileiro, ao não agir politicamente para garantir o confinamento e o isolamento social, além de desestimular o uso de máscaras e promover aglomerações e aligeirar a situação de pandemia ${ }^{17}$, teve e tem tido um elemento sinérgico amplificador da pandemia. Outrossim, os ventos negacionistas do vírus e das práticas de barreiras do contágio tornam-se um obstáculo ao combate à pandemia, igualmente promovidos pelo atual presidente da República e equipe governista, em especial o Ministério da Saúde.

\footnotetext{
${ }^{16}$ Para Stiegler (2008), a proletarização do espírito é a produção em massa de uma "sociedade do controle" com a instituição do psicopoder, que é o controle pelo capital do processo de individuação (formação do aparelho psíquico dos indivíduos) e transindividuação (estabilização do aparelho psíquico de individuação coletiva, desenvolvida por meio da socialização). Em outras palavras, é o controle sistêmico e automatizado da economia dos desejos dos sujeitos.

${ }^{17} \mathrm{O}$ site Aos Fatos sistematizou as sequências de declarações do atual presidente, checando a veracidade delas e como elas foram repetidas. Disponível em: https://www.aosfatos.org/todas-as-declara\%C3\%A7\%C3\%B5es-de-bolsonaro. Acesso em: 23 mar. 2021.
} 
Tais ações têm influenciado enormemente famílias, jovens e grupos sociais. Muitos têm morrido por negarem a doença ou tomarem remédios sem comprovação científica. Há vários casos noticiados sobre as mortes ocasionadas pelo negacionismo, como da influenciadora digital Ygona Moura ${ }^{18}$ e o deputado estadual do Mato Grosso, Sílvio Antônio Fávero, do Partido Social Liberal (PSL), que apresentou um projeto de lei contra a obrigatoriedade da vacina, sob justificativa do direito de escolha do cidadão ${ }^{19}$.

O comportamento de risco tem sido sugestionado pela difusão de mensagens e vídeos, especialmente nas plataformas digitais Youtube, Facebook, Twitter e WhatsApp por líderes políticos, religiosos ${ }^{20}$ e médicos ${ }^{21}$, com efeitos desastrosos para a população em geral.

Com relação aos médicos, a legitimidade deles como portadores do conhecimento científico e do poder simbólico que possuem na sociedade brasileira transforma as informações falsas disseminadas em verdades absolutas e inquestionáveis. A própria omissão do Conselho Federal de Medicina (CONSELHO FEDERAL DE MEDICINA, 2020 ${ }^{22}$ sobre o tratamento precoce com o uso de medicamentes que não foram comprovados cientificamente, conhecido como "Kit Covid", que incluem, com o aval do Ministério da Saúde, cloroquina e sua derivada hidroxicloroquina, azitromicina, ivermectina e anticoagulantes, legitima ainda mais as fake news. Os dois primeiros medicamentos foram objeto do parecer do CFM, que deixou a critério do médico e do paciente a decisão, reafirmando que os médicos que utilizarem os referidos medicamentos não estariam cometendo infração ética ${ }^{23}$. O poder de convencimento das fake news levou Posetti e Bontcheva (2020), em relatório da Organização das Nações Unidas (ONU), a falar em pandemia da desinformação (disinfodemic) - uma desinformação massiva em torno da pandemia da Covid-1924.

Além disso, tem sido comum o apelo à religião como única salvação, expressando pouca crítica à condição de alguns países estarem mais expostos à doença e à maior letalidade e desresponsabilizando autoridades e líderes políticos pelo contexto de crise sanitária. Assim, a descrença na existência da pandemia, o uso de medicamentos não comprovados cientificamente e o comportamento de risco (sem máscaras, aglomerações, tratamento

${ }^{18}$ Portal de notícias do G1. Influencer Ygona Moura morre após diagnóstico de Covid-19. 28 jan. 2021. Disponível em: https://g1.globo.com/pop-arte/noticia/2021/01/28/influencer-ygona-moura-morre-apos-diagnostico-de-covid-19. ghtml. Acesso em: 25 mar. 2021.

${ }^{19}$ Portal de notícias UOL. Morre deputado de MT autor de lei contra a obrigatoriedade da vacina. 13 mar. 2021. Disponível em: https://noticias.uol.com.br/politica/ultimas-noticias/2021/03/13/deputado-estadual-silvio-favero-morte-covid-19. htm. Acesso em: 29 mar. 2021.

${ }^{20}$ Podemos exemplificar a lei municipal do município de Campos dos Goytacazes, que tornou as atividades religiosas essenciais mesmo em situação de lockdown na cidade. O projeto de lei foi proposto por um vereador ligado à Igreja Universal do Reino de Deus. Maiores informações, consultar: TRINIDADE, O. Entre a lei e o bom senso: religiosos e cientistas questionam igrejas abertas na pandemia. Jornal Terceira Via, 28 mar. 2021. Disponível em: <https://www. jornalterceiravia.com.br/2021/03/28/entre-a-lei-e-o-bom-senso-religiosos-e-cientistas-questionam-igrejas-abertasna-pandemia/>. Acesso em: 29 mar. 2021.

${ }^{21}$ Ciência Contaminada - Analisando o contágio de desinformação sobre coronavírus no Youtube, de Caio C. Vieira Machado, Daniel Dourado, João Guilherme Santos e Nina Santos. Disponível em: https://inctdd.org/relatorio-analisadesinformacao-sobre-coronavirus-no-youtube/. Acesso em: 20 jan. 2021.

${ }^{22}$ Reportagem do Jornal Nexo. 12 mar. 2021. Disponível em: https:/www.nexojornal.com.br/expresso/2021/03/12/ Como-a-medicina-lida-com-a-covid-19-ap\%C3\%B3s-um-ano-de-pandemia. Acesso em: 23 mar. 2021.

${ }^{23}$ Para consultar o Parecer CFM no 4/2020, acesse: https://sistemas.cfm.org.br/normas/visualizar/pareceres/BR/2020/4.

${ }^{24}$ POSETTI Julie; BONTCHEVA, Kalina. Desinfodemic. Deciphering COVID-19 disinformation. Paris: UNESCO, 2020. Disponível em: https://en.unesco.org/sites/default/files/disinfodemic_deciphering_covid19_disinformation. pdf. Acesso em: 20 mar. 2021. 
precoce, remédios caseiros), que não está reduzido às classes sociais menos favorecidas economicamente, têm sido comuns.

Em resumo: a psicoesfera fabricou ações que têm tornando a pandemia difícil de ser combatida no Brasil. Logo, os sistemas de crenças, afetos e vontades são elementos sinérgicos inescapáveis para compreensão da difusão do coronavírus. Por sua vez, o meio geográfico contém fatores sinérgicos que podem se manifestar em vários níveis e compor a sindemia global da Covid-19, e as camadas das sociabilidades conectam-se com a tecnoesfera e a psicoesfera - esta última é diretiva dos comportamentos. Portanto, o controle da pandemia passa pela construção de uma nova ordem societária que supere a psicoesfera neoliberal e os negacionismos.

\section{Considerações finais}

Buscamos evidenciar como o meio geográfico é um fator que participou ativamente no desencadeamento e difusão da pandemia da Covid-19. Nesse sentido, consideramos que o coronavírus compõe uma sindemia global ao conter elementos sinérgicos que pioram epidemias já existentes, e o meio geográfico seria parte desse processo. Dessa forma, recuperamos três questões importantes da análise geográfica, em nossa perspectiva, que contribuem para a compreensão das conexões entre o meio geográfico, a urbanização e a sindemia da Covid-19.

A primeira questão diz respeito ao espaço geográfico como papel ativo na produção da sindemia global da Covid-19. O espaço geográfico é parte do contexto sinérgico da pandemia, uma vez que é uma instância social e se concretiza em meios geográficos. O período da globalização tem como concreção o meio técnico-científico-informacional, um híbrido entre formas e ações, cujos elementos-chave são a técnica, a ciência e a informação. Isso significa um meio geográfico onde formas naturais e técnicas se misturam impondo uma nova forma de vida.

A segunda questão analisada, derivada da primeira, é o fato de que o meio técnicocientífico-informacional apresenta uma tecnoesfera (cristalização de ações), cujo papel foi ativo na difusão do coronavírus, pois a geografia das redes de transportes revela o imperativo da fluidez e a unificação dos sistemas técnicos para fins de circulação de mercadorias e pessoas. Isso decorre de uma profunda metamorfose do meio geográfico e mudanças dos ecossistemas e, ao mesmo tempo, implica a velocidade da difusão do vírus. Quanto mais densa a rede de transportes, maiores as chances de se tornarem epicentros da doença. A comunicação que amplifica as notícias falsas e redes negacionistas é a outra face da tecnoesfera, que promove a pandemia da desinformação.

O terceiro aspecto, que também decorre do primeiro e foi o principal objetivo deste texto, é evidenciar que a psicoesfera age sinergicamente para a expansão ou o controle do vírus, pois os sistemas de crenças, desejos e afetos compõem a recepção da informação científica. O que observamos é que não se trata de uma questão menor no controle da pandemia, visto que a negação da pandemia e o comportamento de risco, como a participação de aglomerações e o não uso de máscara, agravaram a difusão do vírus. Além disso, parte dos infectados assumiu o uso de medicamentos não comprovados cientificamente, incluindo médicos que distribuem os receituários. Outrossim, os comportamentos e a atuação de líderes políticos e religiosos têm também rebatimentos 
importantes para a espraiamento do vírus, ao serem produtores ou distribuidores de fake news, especialmente de descrédito na vacina. A psicoesfera neoliberal, que coloca a liberdade individual acima de tudo, preparou o ambiente psicossocial ao negacionismo.

Para concluir, além dos avanços científicos em direção ao tratamento dos pacientes infectados e da busca de vacinas para a prevenção, é preciso ainda fortes investimentos na entronização de comportamentos e um sistema de crenças que leve em consideração a proteção dos cidadãos e cidadãs. Muitas pesquisas ainda precisam ser realizadas para termos a dimensão de como a psicoesfera agiu como elemento sinérgico e condutor dos comportamentos de risco e que coadunou no agravamento da crise sanitária. Por isso, é necessária uma outra psicoesfera para a construção de um outro meio geográfico, mais afeito à solidariedade coletiva e às sociabilidades.

\section{Referências bibliográficas}

CALDEIRA, T.P. R. Cidade de muros: crime, segregação e cidadania em São Paulo. São Paulo: Editora 34-Edusp, 2000.

CARVALHO, D. Evolução da geografia humana. Boletim Geográfico, Rio de Janeiro, v. 3, n. 33, p. 1163-1172, 1945.

CONSELHO FEDERAL DE NUTRICIONISTAS - CFN. A sindemia global da obesidade, desnutrição e mudanças climáticas - Relatório da Comissão The Lancet. 2019. Disponível em: <https:// alimentandopoliticas.org.br/wp-content/uploads/2019/08/idec-the_lancet-sumario_executivo-baixa. pdf>. Acesso em: 25 mar. 2021

CORRÊA, R. L. O espaço urbano. São Paulo: Ática, 1989.

DARDOT, P.; LAVAL, C. A nova razão do mundo. São Paulo: Boitempo Editorial, 2016.

FRÚGOLI, H. Jr. Sociabilidade Urbana. Rio de Janeiro: Jorge Zahar Editores, 2007. Colecção Passo-a-Passo. GEORGE, P. La ville. Le fait urbain a travers le monde. Paris: Presses Universitaires de France, 1952.

HARVEY, D. Neoliberalismo: histórias e implicações. São Paulo: Edições Loyola, 2008.

HORTON, R. Offline: COVID-19 is not a pandemic. Lancet, Vol. 396 September 26, 2020. Disponível em <https://www.thelancet.com/action/showPdf?pii=S0140-6736\%2820\%2932000-6>. Acesso em: 25 mar. 2021.

KAHIL, S. P. Psicoesfera: A modernidade perversa. Revista do Departamento de Geografia, São Paulo, v. 11, p. 217-220, 1997.

KAHIL, S. P. Psicoesfera: uso corporativo da esfera técnica do território e o novo espírito do capitalismo. Sociedade \& Natureza, v. 22, n. 3, p. 475-485, 2010.

KOWARICK, L. Espoliação Urbana. Rio de Janeiro: Paz e Terra, 1979.

LANCET. Syndemics: health in contexto. Lancet, London, v. 389, p. 881, 2017. https://doi.org/10.1016/ S0140-6736(17)30640-2.

LEFEBVRE, H. A Revolução Urbana. Belo Horizonte: Ed. UFMG, 1999 [1970].

MONBEIG, P. Pioneiros e fazendeiros de São Paulo. 2. ed. São Paulo: Hucitec-Polis, 1998.

POSETTI, J.; BONTCHEVA, K. Desinfodemic. Deciphering COVID-19 disinformation. Paris, France: United Nations Education, Scientific, Cultural Organization. Multi-Donor Programme on Freedom of Expression and Safety of Journalists, 2020. Disponível em: <https://en.unesco.org/sites/default/files/ disinfodemic_deciphering_covid19_disinformation.pdf>. Acesso em: 20 mar. 2021.

SANTOS, B. S. A Cruel pedagogia do vírus. Coimbra: Amedina, 2020.

SANTOS, M. A natureza do espaço: técnica e tempo, razão e emoção. São Paulo: Edusp, 2002.

SANTOS, M. Aceleração contemporânea: tempo mundo e espaço mundo. In: CONFERÊNCIA POR OCASIÃO DO ENCONTRO INTERNACIONAL “O NOVO MAPA DO MUNDO”, 1992, São Paulo. Anais... São Paulo: USP, 1992.

SANTOS, M. As Cidades nos Países Subdesenvolvidos. Rio de Janeiro: Civilização Brasileira, 1965. 
SANTOS, M. O meio técnico-científico e a urbanização no Brasil. Espaço \& Debates, São Paulo, n. 25, p. 58-62, 1988 .

SANTOS, M. Técnica, espaço, tempo: globalização e meio técnico-científico-informacional. São Paulo: Edusp, 2008.

SANTOS, M. Urbanização brasileira. São Paulo: Edusp, 2003.

SASSEN, S. The Global City: New York, London, Tokyo. Princeton: Princeton University Press, 2001.

SENNETT, R. Construir e habitar: Ética para uma cidade aberta. Rio de Janeiro: Record, 2018.

SIMMEL, G. A metrópole e a vida mental. In: VELHO, O. (Org.). O fenômeno urbano. Rio de Janeiro. Ed. Gaunabara, 1987. p. 11-25.

SINGER, M.; CLAIR, S. Syndemics and public health: reconceptualizing disease in bio-social context. Medical Anthropology Quarterly, v. 17, n. 4, p. 423-441, 2003. http://dx.doi.org/10.1525/maq.2003.17.4.423.

SOUSA, H. Cyclo Aureo: História do $1^{\circ}$ Centenario de Campos - Memórias Fluminenses. vol. 1. Campos dos Goytacazes: Essentia Editora IFFluminense, 2014.

SPOSITO, M. E. B.; GOÉS, E. M. Espaços Fechados e Cidades: Insegurança urbana e fragmentação social. São Paulo: Unesp, 2013.

STIEGLER, B. Du psychopouvoir à la noopolitique. Concourslibre's Blog. Anais... In: CONFÉRENCE PRONONCÉE DANS LE CADRE DU SÉMINAIRE TROUVER DE NOUVELLES ARMES - POUR UNE POLÉMOLOGIE DE L’ESPRIT. France: Ars Industrialis, 2008. Disponível em: <https://concourslibre. wordpress.com/2011/01/12/conference-de-b-stiegler-du-psychopouvoir-a-la-noopolitique/>. Acesso em: 7 jan. 2021.

\section{Sites e jornais consultados}

INSTITUTO BRASILEIRO DE GEOGRAFIA E ESTATÍSTICA - IBGE. Pesquisa Nacional por Amostra de Domicílios Contínua - PNAD Contínua, 2020. Disponível em: <https://www.ibge.gov.br/estatisticas/ sociais/trabalho/17270-pnad-continua.html?=\&t=o-que-e >. Acesso em: 23 mar. 2021.

ORGANIZAÇÃO PAN-AMERICANA DA SAÚDE. Disponível em: <https://www.paho.org/bra/>. Acesso em: 23 mar. 2021.

CONSELHO FEDERAL DE MEDICINA - CFM. Parecer CFM nº 4/2020. Considerar o uso da cloroquina e hidroxicloroquina, em condições excepcionais, para o tratamento da COVID-19. Conselho Federal de Medicina, 16 abr. 2020. Disponível em: <https://sistemas.cfm.org.br/normas/visualizar/pareceres/ $\mathrm{BR} / 2020 / 4>$

GUIMARÃES, C. Especialistas analisam a disponibilidade de leitos no país e discutem possibilidades. Fiocruz. 08 mai. 2020. Especial COVID-19. Disponível em <https://portal.fiocruz.br/noticia/especialistasanalisam-disponibilidade-de-leitos-no-pais-e-discutem-possibilidades>. Acesso em: 23 mar. 2021.

LACERDA, N. Covid mata mais entre trabalhadores que dependem do transporte coletivo. Brasil de Fato, São Paulo, 18 ago. 2020. Disponível em: <https://www.brasildefato.com.br/2020/08/18/covid-mata-maisentre-trabalhadores-que-dependem-do-transporte-coletivo >. Acesso em: 15 jan. 2021.

TRINIDADE, O. Entre a lei e o bom senso: religiosos e cientistas questionam igrejas abertas na pandemia. Jornal Terceira Via, 28 mar. 2021. Disponível em: <https://www.jornalterceiravia.com.br/2021/03/28/ entre-a-lei-e-o-bom-senso-religiosos-e-cientistas-questionam-igrejas-abertas-na-pandemia/>. Acesso em: 29 mar. 2021. 
Silvana Cristina da Silva. Graduada, mestre e doutora em Geografia pela Universidade Estadual de Campinas (UNICAMP). Pós-doutora em Sociologia pela École Normale Supérieure, de Paris. Professora e pesquisadora do Departamento de Geografia e do Programa de Pós-Graduação em Geografia do Instituto de Ciências da Sociedade e Desenvolvimento Regional da Universidade Federal Fluminense (UFF), em Campos dos Goytacazes. Coordenadora do Grupo de Pesquisa Território e Cidades (TeCidades).

Gabrielle Lorena Gomes da Silva. Graduanda do curso de Geografia da Universidade Federal Fluminense (UFF), em Campos dos Goytacazes. Bolsista do Projeto de Pesquisa, Ensino e Extensão intitulado "Espaço urbano e a pandemia da COVID-19: conflitos e mudanças das sociabilidades urbanas", Edital PROPPI - PROGRAD - PROEX No 04/2020/UFF 2020. Membro do Grupo de Pesquisa Território e Cidades (TeCidades).

Jenyffer Vidal Oliveira. Graduada em Geografia pelo Instituto Federal Fluminense (IFF), em Campos dos Goytacazes. Mestranda do Programa de Pós-Graduação em Geografia da Universidade Federal Fluminense (UFF), em Campos dos Goytacazes. Bolsista do Projeto de Pesquisa, Ensino e Extensão intitulado "Espaço urbano e a pandemia da COVID-19: conflitos e mudanças das sociabilidades urbanas", Edital PROPPI - PROGRAD - PROEX No 04/2020/ UFF 2020. Membro do Grupo de Pesquisa Território e Cidades (TeCidades).

Renata Hilel Ribeiro. Graduada em Geografia pela Universidade Federal Fluminense (UFF), em Campos dos Goytacazes. Mestranda do Programa de Pós-Graduação em Geografia da UFF, em Campos dos Goytacazes. Bolsista do Projeto de Pesquisa, Ensino e Extensão intitulado "Espaço urbano e a pandemia da COVID-19: conflitos e mudanças das sociabilidades urbanas", Edital PROPPI - PROGRAD - PROEX No 04/2020/UFF 2020. Membro do Grupo de Pesquisa Território e Cidades (TeCidades). 
Sendo assim, a "Geografia dos Espaços Alternativos, outras possibilidades, novas esperanças" não foi simplesmente um estudo de utopias ou um vislumbre de um mundo melhor, mas procurou analisar o espaço geográfico com base no pensamento de autores que já propuseram alternativas para o mundo existente, buscando em suas ideias pistas para outras possibilidades.

O termo "pistas" é adequado, pois, diante da complexidade do tema e dos textos estudados, seria leviano considerar que, a partir da disciplina, o grupo encontraria soluções efetivas. Por isso, uma das premissas nos encontros ocorridos foi a de que aqueles estudos precisavam ser encarados como um ponto de partida, e não de chegada. Esse foi o motivo pelo qual, talvez, muitos (incluindo o professor) tenham finalizado algumas aulas com mais dúvidas do que certezas. E, se isso ocorreu, em algum momento e de alguma forma, a proposta foi alcançada.

Dois livros foram a base norteadora dos encontros: Por uma outra globalização (SANTOS, 2003) e Espaços de Esperança (HARVEY, 2004). Partindo de suas leituras e refletindo sobre as ideias desses autores, avançou-se para outros temas que serão debatidos no decorrer deste texto. Certamente, o estudo das duas obras necessitaria de mais tempo do que o disponibilizado, mas, na medida do possível, extraíram-se os substratos que permitiram tecer questionamentos e reflexões.

Tendo os dois primeiros objetivos esclarecidos (estudar as obras e questionar a ordem vigente), um terceiro objetivo veio como um exercício: pensar em outras possibilidades para a construção de um mundo melhor.

Em um momento histórico em que as pessoas parecem ter desistido ou até se conformado com a ordem das coisas, o estudo da Geografia dos Espaços Alternativos vem como uma resposta para que, ao menos no coração de uns poucos, a chama revolucionária se mantenha acesa.

\section{SITUANDO A DISCIPLINA NO CONTEXTO ESPAÇO-TEMPORAL}

No dia 11 de março de 2020, em razão de sua disseminação no mundo, a Covid-19 foi caracterizada pela OMS como uma pandemia (ORGANIZAÇÃO PAN-AMERICANA DA SAÚDE, 2020), o que implicou e ainda tem acarretado o impacto da sociedade global, em suas distintas instituições e estruturas.

Em meio a esse contexto, a maior parte dos municípios e estados brasileiros decretou o fechamento de seus territórios e a restrição de atividades que implicassem aglomerações populacionais. Por consequência, as aulas na UFF foram suspensas e só retornaram na modalidade de ensino a distância, com a ênfase do Programa de Pós- Graduação em Geografia da UFF-Campos de que tal medida foi adotada unicamente como paliativo para mitigar os danos da Covid-19 no campo da educação. Os professores do Programa consideram que as vantagens da educação presencial são insubstituíveis por outra modalidade.

Com isso, a disciplina "Geografia dos Espaços Alternativos”, que ocorreria no primeiro semestre de 2020, teve seu início adiado para o segundo semestre, e, assim, às $14 \mathrm{~h}$ do dia 11 de agosto de 2020, a turma, que totalizava 12 alunos e o professor, reuniu-se por videoconferência. 
As aulas contaram com diferentes objetivos, mas alguns eram comuns em todas, como contextualizar espaço-temporalmente os autores dos livros estudados, para que todos pudessem compreender suas ideias. À medida que se avançou, ocorreu um esforço em retomar as ideias dos autores já estudados para comparar e traçar reflexões com as do livro da vez. Esse último objetivo possibilitou a percepção de convergências nos pensamentos dos autores analisados, como a identificação de problemas comuns e o apontamento de soluções similares, ainda que por palavras ou caminhos distintos.

Alguns livros necessitaram de dois a três encontros; outros foram debatidos em um único dia. A dinâmica das aulas não era igual de uma para outra. Para os livros maiores, foram divididos os capítulos por membros da turma, que debatiam cada um deles com o professor, sendo permitida e incentivada a interação entre o grupo. Nos livros de menor robustez, todos liam e interagiam segundo suas compreensões. Mesmo com a proposta clara, muitas vezes era necessário fazer questionamentos ao grupo no intuito de incentivar os debates, o que será detalhado na seção referente às dificuldades encontradas no modelo EAD.

\subsection{Dificuldades e superações}

O planejamento da disciplina contava com aula de campo e diferentes dinâmicas de interação em sala de aula, e isso precisou ser modificado, representando uma desvantagem, pois a comunicação por videoconferência não se compara com a presencial, além da perda de uma saída de campo, a qual é essencial nos estudos em Geografia.

Ainda que o ambiente virtual facilite a questão do deslocamento e evite as aglomerações (algo essencial no momento em que vivemos), ele possui carências que dificilmente serão supridas. A primeira e principal é a da restrição da interação professor-aluno e da própria turma entre si. As aulas on-line têm restringido o contato visual e sonoro, o que inibe um fluxo de diálogos e construção de ideias. A internet consiste em uma boa ferramenta para divulgar palestras sem interações entre o palestrante e a plateia, mas a aula não é uma palestra. Ainda, em razão de os alunos precisarem desligar suas câmeras e som para evitar falhas de imagem e microfonia, o professor, muitas vezes, não consegue sentir se a turma está acompanhando de fato ou se tem alguém "assistindo à aula" e lavando os pratos ou conversando no WhatsApp.

Outra dificuldade girou em torno do acesso aos materiais de apoio. Como se sabe, tirar cópia dos livros trabalhados é uma prática comum da maior parte dos alunos. Se esse material não estiver disponibilizado em PDF na internet, os alunos então ficam, muitas vezes, sem acesso a um livro específico.

Com isso, podem ocorrer restrições na ausência de um aporte financeiro que custeie o processo de digitalização das obras requisitadas para uma disciplina por determinado professor. A primeira restrição é a de tempo, pois, na possibilidade de o professor, por sua conta, fazer a digitalização das obras, ocorrerá uma sobrecarga de trabalho. Se não for assim, poderá haver uma restrição de conteúdo possível, sendo necessária a adaptação ao que há disponível na internet.

Para a disciplina em questão, esse não foi um grande inconveniente, pois $80 \%$ do material que se pretendia trabalhar estava disponibilizado gratuitamente na internet, principalmente por serem clássicos, mas isso não teria ocorrido no caso de outra disciplina que não tivesse essa particularidade. 
O excesso de tempo em frente ao computador também é um inconveniente para os professores e alunos. $\mathrm{O}$ acúmulo de atividades virtuais, tais como aulas, estudos, reuniões, faz com que as pessoas se sintam cansadas desse "ambiente", e isso impacta diretamente no rendimento nas aulas. É importante ressaltar que, no contexto da pandemia, até mesmo o lazer e a interação ficaram restritos (pelo menos do final do primeiro semestre até pouco mais da metade do segundo) aos meios virtuais. Sendo assim, o excesso de uso da internet e do computador implicou efeitos colaterais que qualquer pessoa mais atenta pôde notar, inclusive em si mesma.

Um exemplo foi constatado no processo de diálogo estabelecido durante os encontros. Em três momentos no decorrer do semestre, foi necessário interromper a aula e fazer uma prática de relaxamento com os alunos, que se mostravam estafados com o ambiente virtual.

No que se refere à apreensão do conteúdo, evidenciou-se que a maior dificuldade da classe não se encontrava na complexidade das leituras, mas no quanto elas se aproximavam ou distanciavam de seus domínios conceituais e de seus conhecimentos a respeito da história. Em termos práticos, isso significou que autores mais contemporâneos e caros à Geografia, como Milton Santos e David Harvey, tiveram suas ideias melhor compreendidas do que outros autores, como Platão ou Thoreau.

Uma vez que as principais questões referentes às dificuldades e superações que envolveram a disciplina foram comentadas, passa-se então para a segunda parte deste texto, que visa tecer considerações a respeito das teorias trabalhadas.

\section{ANÁLISES E REFLEXÕES}

Os dados chegam por todas as partes, e a confusão é generalizada. Enquanto as teorias e o obscurantismo abundam, o tempo se torna escasso. Perdidos no mar das incertezas, lutamos para sobreviver em meio ao caos e, absorvidos pelo sistema, somos pouco a pouco anestesiados.

Alguns se erguem e atacam, mas atacar quem ou o quê? Quem é o verdadeiro inimigo a ser destruído? Diante da fragmentação e da polarização, em meio à alienação, impera por parte de alguns mais lúcidos a frustração e até mesmo o pessimismo. "A incapacidade de descobrir um 'otimismo do intelecto' com que trabalhar em busca de alternativas tornou-se hoje um dos mais sérios obstáculos à política progressista” (HARVEY, 2004, p. 30).

É preciso inspirar-se nas utopias, nas propostas, por mais esdrúxulas que pareçam, por mais loucas que sejam consideradas, mas elas consistem no movimento de quem não se conformou com a ordem das coisas e, assim, buscou promover mudanças. Se lutar contra a perversidade do mundo é ser louco, então brindemos a loucura.

\subsection{Os espaços de utopia}

No capítulo "Os espaços de utopia," do livro Espaços de Esperança, David Harvey explana as diferentes formas como as utopias foram propostas e até mesmo materializadas no mundo. Primeiramente, aponta como as figuras da cidade e a utopia "há muito se acham entrelaçadas" (HARVEY, 2004, p. 207). O autor lembra como o planejamento urbano historicamente é influenciado por ideais utópicos e, assim, parte para uma esquematização do que considera sendo as utopias da forma e do processo, para então chegar a uma terceira, a utopia dialética. 


\subsubsection{As utopias da forma}

A utopia da forma, para Harvey, estaria centrada no que ele intitula como sendo o utopismo enquanto livre organização espacial. O autor cita alguns exemplos, dos quais se pode destacar o clássico Utopia, de Thomas Morus (2001), escrito em 1516. Em sua análise sobre essa obra de More, Harvey explica (2004, p. 211) que "A organização espacial interna da ilha regula de maneira estrita um processo estabilizado e imutável. Para dizer de modo direto, a forma espacial controla a temporalidade [...]". Em outras palavras, os processos socioespaciais são travados pela estrutura engessada.

Cabe ressaltar que todos os esquemas utópicos propostos após More guardam como similaridades uma influência clássica do modelo de cidade justa platônica e, mais do que isso, possuem em seu cerne uma denúncia contra a ordem das coisas estabelecidas. No caso de More, trata-se de uma crítica à sociedade burguesa em ascensão e à decadente sociedade feudal.

Harvey prossegue com ilustrações de como esses esquemas utópicos da forma espacial se materializaram no Projeto New Harmony, de Robert Owen; no da Cidade Ideal, de Fourier; na Roadtown, de Edward Chambless; no "movimento das novas cidades", de Ebenezer Howard; na Cidade Ideal, de Le Corbusier; e no projeto da Broadacre City, de Frank Lloyd Wright. Após isso, o autor chega a exemplos contemporâneos, intitulados por ele de nostalgias utópicas.

\subsubsection{As utopias do processo social}

Sobre o utopismo do processo social, Harvey considera que, apesar de parecer estranho o uso do termo "utopia" associado a algo que não seja um não lugar ou um lugar feliz, são inúmeros os esquemas que idealizam o processo. Para ele, "As versões idealizadas dos processos sociais, em contrapartida, costumam exprimir-se em termos puramente temporais" (HARVEY, 2004, p. 228).

Em suas críticas às utopias do processo, considera que se perdem romanticamente em meio a projetos infindavelmente abertos, os quais, por sua vez, não chegam a um ponto de conclusão, que seria as suas materializações no espaço e no lugar.

Ele menciona a necessidade que Marx teve de desconstruir um utopismo do processo distinto do seu, referindo-se à obra A Riqueza das Nações, de Adam Smith (1996), publicado em 1776. Após percorrer em uma análise do passado ao presente considerando essa oposição de ideias, ressalta o que assinalou Frankel em 1987 e ratifica que "os mais eficazes utopistas em épocas recentes têm sido os de persuasão direitista, que têm adotado primordialmente antes um utopismo do processo do que um utopismo da forma espacial" (HARVEY, 2004, p. 232).

Tal afirmação provoca a seguinte reflexão: até que ponto não compramos e aceitamos a utopia capitalista burguesa enquanto rechaçamos outras possibilidades? Ainda que o pensamento burguês seja de fato uma ideologia que domina a psicosfera (SANTOS, 2008), o paraíso capitalista, vendido a todos, não passa de uma utopia que nunca se materializou e nunca se cristalizará da forma como é idealizada por seus mais fiéis defensores.

\subsubsection{Síntese}

Se, por um lado, as utopias da forma espacial pervertem seus objetivos pela necessidade de controlar os processos sociais, as utopias do processo social, ao negociarem com a espacialidade, quando cristalizadas produzem resultados opostos ao que pretendem (como 
autoritarismo e desigualdades). Partindo dessa premissa, Harvey sintetiza uma proposta que consiste em um utopismo espaço-temporal (HARVEY, 2004, p. 239).

Considera então que a alternativa não deve ser ficar em uma forma espacial estática nem enfocar um processo emancipatório aprimorado. A busca então estaria em montar um utopismo espaço-temporal (dialético) "que tenha raízes fincadas em nossas possibilidades presentes ao mesmo tempo que aponta trajetórias diferentes para os desenvolvimentos geográficos desiguais humanos" (Idem, p. 258). E, assim, ele conclui a terceira parte de seu livro, intitulada "O momento utópico", mas que para este texto oferece substrato para novas reflexões.

\subsection{Despertando olhares}

Vivemos em uma sociedade de pessoas adormecidas. Acreditamos saber tudo e ignoramos que nada sabemos. Bombardeados constantemente pela máquina ideológica que nos fascina, buscamos a ilusão em uma falsa felicidade, ao considerar que esta seja algo a ser conquistado pela ascensão econômica, via necessária para acessar o dinheiro e, por sua vez, o consumo.

Como pensar na construção de um mundo diferente, se cada indivíduo se encontra impregnado de valores e ideias que forjam a estrutura ideológica de uma sociedade perversa? Milton Santos (2008), ao conceber a existência de uma tecnosfera e de uma psicosfera, leva-nos a refletir que não há como transformar uma sem alterar a outra. Mudanças estruturais não atingem resultados distintos, se não vierem acompanhadas de mudanças nas concepções.

Sendo assim, antes mesmo de se pensar em mudar o mundo exterior, é coerente voltar a atenção para o interior, chocar a consciência na busca de romper os grilhões que aprisionam a mente com as falsas verdades. Três passos são fundamentais ${ }^{1}$, tais como nos aponta Platão com a alegoria da caverna, em sua obra A República (PLATÃO, 1949).

O primeiro passo é perceber que as sombras projetadas na parede não são a realidade, mas isso não é possível sem uma postura crítica e questionadora. Por que as coisas são como são? Elas precisam ser do jeito que são? Deve-se recordar que, na alegoria proposta por Platão, os escravos mais sábios e respeitados eram os que interpretavam aos demais as sombras na parede; logo, não passavam de meros reprodutores da linguagem do sistema.

Em comparação com nossos tempos, até que ponto o sistema educacional contribui para cumprir com a formação de indivíduos verdadeiramente livres? Os professores são livres? Caso não, como pessoas cativas podem ensinar alguém a ser livre? No entanto, o que é ser livre? Há uma máxima que afirma que o conhecimento liberta, mas, se é assim, como explicar a quantidade de pessoas que, no mundo acadêmico, sofrem de ansiedade, depressão, insônia e outros problemas típicos de pessoas aprisionadas?

Em nossa compreensão, liberdade e felicidade são palavras relacionadas, ou seja, uma é consequência da outra. Basta um breve passeio pela história para observar que, mesmo encarceradas ou ameaçadas, as mentes livres se mantiveram em paz.

Entende-se que a liberdade dos grilhões da caverna não pode ocorrer se aceitamos como verdade as coisas que são dadas do jeito que são. Aqui se encontra um importante papel para o professor ensinar a pensar. Para Weor (2019, p. 49), “Todo o esforço dos professores deve, em última síntese, levar os alunos e alunas à experiência do real, do

${ }^{1}$ Os passos serão apresentados no decorrer do texto, estando o segundo passo na seção 3.3 e o terceiro passo na seção 3.4 . 
verdadeiro". É por isso que A República, de Platão, mais do que um tratado em que se reflete a respeito da justiça, é também uma obra sobre a educação, já que esse é o único instrumento que pode levar cada indivíduo a libertar sua mente e alcançar a verdade. Mas o que é a verdade? Segundo Weor (2019, p. 48), "A verdade é o desconhecido de momento a momento."

O papel que exerce a educação para promoção da liberdade, vislumbrada desde Platão como instrumento de modificação da estrutura social, foi observado em 1985 por Lacoste (2012), em sua obra: A Geografia, isso serve em primeiro lugar para fazer a Guerra. Ainda, o autor evidencia em seu texto a importância do professor e da educação para a transformação social.

No capítulo intitulado "Saber pensar o espaço para saber nele se organizar, para saber ali combater" (LACOSTE, 2012, p. 177), o autor considera que, sem se apropriar do conhecimento geográfico e de uma adequada leitura espacial em suas diferentes escalas e arranjos espaciais, não há como os cidadãos tomarem a consciência da complexidade do mundo em que estão inseridos. "Os cidadãos mais politizados, os militantes, devem fazer uma análise espacial da crise em diferentes escalas, para ajudar na tomada de consciência coletiva dos problemas" (Idem, p. 182).

Considerando a abordagem de Santos (2003) sobre o que entende como período popular, é possível extrair algumas reflexões a respeito do tema em questão. Sua aposta na apropriação da técnica por parte das camadas populares subvertendo o domínio exercido pelo sistema não poderá ocorrer com uma população idiotizada e alienada pelas redes sociais e fábulas contemporâneas.

Talvez, por isso, um dos primeiros pontos que são notórios na lógica de construção do pensamento por parte dos pensadores que apresentaram as suas utopias é que elas são antecedidas por denúncias do sistema. Essas denúncias consistem na exteriorização dos choques de consciências que se assombram ao observar a estrutura dos modelos vigentes (cada qual em seu contexto espaço-temporal) e, partindo da distopia vivida, não se contentam em aceitá-las, mas buscam proposições. São as consciências que, de uma forma ou de outra, lutaram para avivar a chama da esperança, combatendo os conformismos com suas ideias e posturas revolucionárias.

O estudo dos pensamentos utópicos permite o despertar para situações do espaço geográfico, as quais, apesar de injustas, parecem normais, pois a presença cotidiana delas na vida de cada pessoa tende a torná-las banais. Ao mesmo tempo, essas situações apontam a existência de outras possíveis geografias. Se cada mente é um Universo, é correto afirmar que, dentro de cada cabeça, há uma utopia, e as pessoas, de forma consciente ou não, buscam por seu mundo melhor (por suas utopias).

\subsection{Em busca da verdade}

Continuando a alegoria da caverna (como fio condutor deste texto), após se dar conta que não está mais acorrentado, o agora liberto é impulsionado a escalar a caverna até o topo, sentindo então a dor de se deparar com a realidade e, aos poucos, acostumando-se com a luz e conhecendo a verdade. Primeiramente, não olha direto ao Sol, mas observa as sombras projetadas por ele; depois, contempla a noite, até o momento em que sua vista está preparada para mirar ao alto.

Assim como na alegoria, as explicações que antes eram satisfatórias ao indivíduo já não o são, o que o faz perceber sua condição de alienado. Então, ele tem a necessidade de 
investigar a fundo os problemas, no intuito de encontrar novas respostas. Um exemplo está na obra Geografia da fome, de Josué de Castro (2011), na qual o autor quebrou paradigmas sobre o tema no Brasil, oferecendo uma análise aprofundada a respeito das questões sociais, transcendendo, assim, as afirmações até então aceitas como verdadeiras de que a explicação para a fome seria de ordem climática.

No entanto, evoca-se a premissa de Weor (2019) a respeito de uma verdade que não pode ser estática, já que ela é desconhecida a cada novo momento. Sendo assim, hoje, somam-se à questão da carência de nutrientes outros fatores relacionados ao alimento, os agrotóxicos e transgênicos, a comida industrial enxertada de hormônios e químicos, além da empobrecida dieta de cada indivíduo. Quando se toma como normal a situação da alimentação no mundo e, especificamente, no Brasil, corrobora-se o sistema. O atual problema da alimentação está nas vidas dos ricos e pobres ${ }^{2}$, dos intelectuais e religiosos, dos homens e das mulheres, etc.

Há uma estruturação nociva que se inicia nas monoculturas, estende-se pela produção dos alimentos e se infiltra em nossos lares, onde levamos veneno para o corpo e nos matamos homeopaticamente. Um dos convidados para colaborar com a disciplina ${ }^{3}$, médico e professor da Universidade Estadual de Feira de Santana, José Rosa Figueiredo Filho, explicou minuciosamente como grande parte das doenças contemporâneas começa pela má alimentação, inclusive decorrente da ingestão de transgênicos e outros venenos, a exemplo dos refrigerantes e processados.

O mais grave foi a constatação de que há uma continuidade nesse ciclo de criação de doenças que se estende à indústria farmacêutica. O médico teceu uma forte crítica à grande parte dos remédios alopáticos, os quais, muitas vezes, além de não curarem, geram novas enfermidades em razão de seus efeitos colaterais.

Jaques Brient (2009) denuncia como nos tempos atuais, diferentemente de outros modelos que já existiram, o 'servo moderno' se escraviza de forma voluntária. O autor explica que esses escravos são os que compram as mercadorias que cada vez mais os aprisionam, buscam os seus trabalhos alienantes e escolhem os amos a quem querem servir. No capítulo intitulado "A Alimentação", ele comenta:

Porém é quando se alimenta que o escravo moderno ilustra melhor o estado de decadência em que se encontra. Dispondo de um tempo cada vez mais limitado para preparar a comida que ingurgita, ele se vê obrigado a engolir rápido o que a indústria agroquímica produz, errando pelos supermercados à procura dos ersatzes que a sociedade da falsa abundância consente em dar-lhe. Aí, ainda, só lhe resta a ilusão da escolha. A abundância dos produtos alimentícios apenas dissimula sua degradação e sua falsificação. Não são mais que organismos geneticamente modificados, uma mistura de colorantes e conservantes, de pesticidas, de hormônios e de outras tantas invenções da modernidade. O prazer imediato é a regra do modo de alimentação dominante, também é a regra de todas as formas de consumo. E as consequências que ilustram esta forma de alimentação se veem em todas as partes (BRIENT, 2009, p. 5).

Brient também tece sua crítica à medicina ocidental, chamando-a de medicina mercantil. Para o autor, ela não ataca a origem do mal do escravo moderno, que está

\footnotetext{
2 No entanto, é claro que este problema gera um impacto muito maior às populações com menor poder aquisitivo.

3 Por questões de tempo, essa aula, assim como outras que teriam convidados externos, foi suprimida, mas o tema havia sido explicado anteriormente em palestra dada pelo professor José Rosa em 2018 na comunidade Olimpo, em Santo Amaro, Bahia.
} 
na "degradação generalizada de seu ambiente, do ar que respira, e da comida que ele consome; o stress provocado pelas suas condições de trabalho e pelo conjunto de sua vida social" (Idem, p. 10).

Partindo desses exemplos iniciais, obtém-se um conjunto de fatores geográficos que passam despercebidos, ignorados ou até mesmo concebidos como normais. Quais relações podem ser traçadas entre as doenças do mundo moderno e a estruturação do espaço geográfico? A qualidade da alimentação e de todos os aspectos da vida vem sendo debilitada de momento em momento, sendo consequência de uma estrutura nociva pela qual o processo de globalização se expande por todo o planeta.

Assim, é possível questionar toda a estrutura que compõe o sistema: o que se entende por trabalho, lazer, educação, saúde, alimentação, política, sexualidade, religião, entre tantos outros elementos que se combinam no mosaico do espaço geográfico, mas que são construídos na psicosfera social, de maneira a incentivar as individualidades, exacerbando as diferenças e fragmentando as lutas. Dividir para conquistar é uma abordagem ensinada na Arte da Guerra, de Sun Tzu (1996), aplicada por Júlio Cesar em Roma e que cada vez mais se evidencia como estratégia nos tempos atuais.

Retorna-se, então, ao ponto inicial desta reflexão. Em uma sociedade de pessoas adormecidas, que constantemente são manipuladas pelas informações que contribuem para a manutenção do sistema hegemônico, observa-se que a busca pela verdade, ainda que bem-intencionada, e única via para uma transformação social, torna-se paradoxalmente um calcanhar de Aquiles. Entre outros motivos, observa-se que isso vem ocorrendo, principalmente, em razão do excesso de desinformação que reina pelas redes sociais e da identificação com as polarizações sensacionalistas e politiqueiras.

A falta de crivo crítico por parte de indivíduos, os quais, buscando contestar a ordem vigente, apegam-se a novas crenças ${ }^{4}$ (novos deuses) indo de encontro a qualquer lógica ou coerência, transforma as bases que possibilitariam a insurgência de um momento revolucionário em uma tragédia social.

\subsection{A fragmentação}

$\mathrm{Na}$ alegoria da caverna, após conhecer a verdade, o homem livre retorna para alertar aos companheiros aprisionados, mas suas palavras e ações não são bem recebidas nem consideradas. Assim como no exemplo dado por Platão, quase sempre são combatidos aqueles que, inconformados com o sistema opressor, vislumbram a possibilidade de um mundo melhor e buscam lutar por isso. A história mostra que, em casos extremos, esses indivíduos receberam como pagamento as cicutas, as prisões, as crucificações...

Milton Santos (2003) analisa o processo de globalização em três perspectivas. $\mathrm{Na}$ primeira, intitulada a "globalização como fábula", o autor aponta os mitos da globalização segundo a imagem, que nos fazem crer a respeito do processo. Ele destaca o papel da máquina ideológica para o sustento das ações hegemônicas. Um dos exemplos trazidos por Santos é o do mercado global, "apresentado como capaz de homogeneizar o planeta, quando, na verdade, as diferenças locais são aprofundadas" (SANTOS, 2003, p. 19).

Na segunda perspectiva, em sua visão sobre o mundo real definindo "a globalização como perversidade”, Santos demonstra um cenário em que há o aumento da pobreza e a perda

\footnotetext{
${ }^{4}$ Entre defensores da Terra plana e da cloroquina, novos mitos se criam, e seus seguidores como devotos de uma seita fanática se negam a dialogar a respeito de qualquer outra possibilidade.
} 
de qualidade de vida das classes médias, generalizando-se a fome e o desabrigo, além da proliferação de velhas e novas doenças. O autor ressalta a questão da mortalidade infantil e da inacessibilidade a uma educação de qualidade e, por fim, assinala o aprofundamento dos "males espirituais e morais, como os egoísmos, os cinismos, a corrupção" (Idem, p. 20).

Na terceira perspectiva, traz sua utopia a partir da premissa de que a intensificação da mistura de povos e filosofias em todos os continentes e a maior aglomeração populacional em áreas de alta densidade demográfica permitem um maior dinamismo na mistura entre pessoas e filosofias. Com isso, a existência de uma sociodiversidade, unida ao que ele entende como sendo uma cultura popular servida "dos meios técnicos antes exclusivos da cultura de massas" (SANTOS, 2003, p. 21), torna possível o exercer de uma revanche ou vingança. Ainda sobre a cultura popular, afirma:

Tal cultura realiza-se segundo níveis mais baixos de técnica, de capital e de organização, daí suas formas típicas de criação. Isto seria aparentemente, uma fraqueza, mas na realidade é uma força, já que se realiza, desse modo, uma integração orgânica com o território dos pobres e seu conteúdo humano (SANTOS, 2003, p. 145).

Vale ressaltar a distinção feita pelo autor entre pobreza e miséria, uma vez que, enquanto a última implica a privação completa e quase o aniquilamento da pessoa, a primeira consiste "em uma situação de carência, mas também de luta, um estado vivo, de vida ativa, em que a tomada de consciência é possível" (Idem, p. 132).

Ainda que em estado de carência, o pobre, tendo acesso aos meios técnicos, encontra ferramentas para sua articulação política e social. Assim, é possível observar hoje pelas redes sociais movimentações e organizações envolvendo diferentes setores da sociedade, e, com isso, o papel da classe média é estratégico na visão do autor.

Para Santos (2003), à medida que experimenta um momento de escassez, a classe média, muitas vezes, tende a reagir negativamente à política, ou seja, desejando menos política e participação, quando, na verdade, sua reação pode e deve ser oposta. Ele considera que "seu papel não estará completo enquanto não se identificar com os clamores dos pobres, contribuindo, juntos, para o rearranjo e a regeneração dos partidos, inclusive, os partidos do progresso" (Idem, p. 139).

Cabe então refletir a respeito da conjuntura atual vivenciada no país. Inicialmente, ressalta-se o surgimento ou a evidência pelas redes sociais de grupos das camadas populares que defendem e se identificam com os interesses das elites. Serão listados alguns elementos que podem explicar tal fenômeno, não no intuito de apresentar uma explicação que se esgote, mas de pontuar algumas das análises feitas sobre o tema.

Em uma observação empírica da realidade brasileira, elencam-se sete pontos que constituem entraves para articulações políticas nas camadas populares do país. São eles: 1) a manipulação da informação pelos grupos hegemônicos; 2) a alienação e o conservadorismo religioso; 3 ) o acesso ao meio técnico informacional sem os instrumentos críticos necessários para sua utilização e clivagem das informações; 4) a emergência de uma esquerda liberal, que tem por objetivo a inserção dos grupos minoritários na estrutura capitalista pelo acesso ao consumo e pela ampliação dele, enquanto a luta para derrubar essas estruturas é negligenciada ou esquecida, o que contribui para uma alienação por parte da população, que enxerga no próprio sistema a alternativa para a ascensão social; 5) a fragmentação das lutas sociais, solapando possibilidades de uma unidade da luta de classes; 6) a amplificação das tensões geradas pelas polarizações, que terminam por criar 
antipatias por causa do enfoque nos ressentimentos por parte de alguns grupos (não de todos); 7) a dificuldade em utilizar-se de linguagens e meios que alcancem as camadas populares e que seduzam a classe média por parte dos grupos intelectuais, que buscam por transformações progressistas.

Partindo dessa listagem simplificada de fatores e considerando o entrave posto, que é a fragmentação das lutas e visões, associada aos aspectos de uma sociedade competitiva e individualista, cuja alienação com relação à sua condição de escravidão moderna contribui para a permanência e o fortalecimento das estruturas do sistema, chega-se ao impasse na busca de uma via que congregue as diferenças.

\subsection{A construção de uma utopia não exclui as heterotopias}

Em Espaços de Esperança, Harvey nos convida a refletir sobre a máxima neoliberal de que "não há alternativas". O autor questiona tal afirmação e, partindo dela, propõe uma análise do espaço geográfico, inicialmente pela leitura de O Capital, de Karl Marx, e do Manifesto do Partido Comunista, de Karl Marx e Friedrich Engels. Harvey segue então na busca de compatibilizar a leitura histórica e econômica desses autores, ora os criticando, ora apontando sua atualidade e demostrando como a Geografia está presente em suas obras.

Comentando o Manifesto do Partido Comunista, Harvey considera que as bases do cenário em que ele foi escrito não sofreram mudanças radicais, uma vez que: "O proletariado global nunca foi tão volumoso, nem nunca tão forte o imperativo da união dos trabalhadores de todo o mundo" (HARVEY, 2004, p. 68), mas, ao mesmo tempo, considera que "as barreiras à essa união são muito mais formidáveis do que eram no contexto europeu já complicado de 1848" (Ibidem).

Harvey ressalta que, em toda parte, existem lutas anticapitalistas, com manifestações "de raiva e de descontentamento" (Idem, p. 102). E essa é uma potência emergente, ao considerar que, em grande parcela dos casos, as insatisfações possuem uma mesma base estrutural, que é o próprio sistema, mas o não enxergar a causa comum implica que, além das lutas individuais, desmobilize-se uma marcha única.

Parece haver uma concordância entre alguns autores estudados no que se refere à necessidade da articulação das diferentes pautas, visando a um ponto central de ataque. Se, por um lado, a máxima "Trabalhadores de todos os países uni-vos" (ENGELS; MARX, 1999, p. 65) ecoa como um grande chamado para essa união das forças, Harvey considera (2003, p. 103) que "O trabalho de síntese das múltiplas lutas hoje existentes tem de ser permanente [...]". A necessidade dessa união de movimentos também é o ponto de conclusão de Brient, quando afirma: "Mas, para que desta revolta surja uma revolução, é preciso reunir as subjetividades em uma frente comum" (BRIENT, 2009, p. 22) O autor ainda enfatiza que: "É na unidade de todas as forças revolucionárias que devemos trabalhar" (Ibidem).

Santos, assim como os demais, também considera importantes as pautas particulares, mas enfatiza a necessidade de um enfoque central das lutas, primeiramente evidenciando que, "entre as violências de que se fala, a maior parte é, sobretudo, formada de violências funcionais derivadas [...]" (SANTOS, 2003, p. 55), e alerta que, enquanto o enfoque se concentra nas derivações, "a atenção é menos voltada para o que preferimos chamar de violência estrutural, que está na base da produção das outras e constitui a violência central original" (Ibidem). 
Ainda que apresentando caminhos distintos, nota-se a convergência das visões na necessidade de unificação da luta para o combate ao problema sistêmico, que é estrutural. Quando Platão propõe em A República o exercício da criação de uma cidade justa e faz isso partindo do zero, evidencia que a justiça não poderá ser alcançada com paliativos em um sistema contaminado por perversidades. Se as lutas contra as violências estruturais são enfocadas nas derivações, a causa nunca será sanada; assim, enquanto se combatem os sintomas, a raiz dos males permanece intacta e intocada, já que as atenções são desviadas para as suas consequências.

Como já afirmado, o caminho para tal partirá de diferentes perspectivas, e uma das compreensões norteadoras desta reflexão é que elas não precisam ser suprimidas. A respeito disso, Hakim Bey (2019) aponta uma possibilidade ao trabalhar com a ideia de zonas autônomas temporárias (TAZ).

Inicialmente, ele descreve, com base no romance Ilhas na Rede, de Bruce Sterling, uma realidade futurista com a "proliferação de experiências comunitárias descentralizadas" (BEY, 2019, p. 3), as quais continham diferentes concepções, indo desde corporações gigantescas, mantidas por seus funcionários, aos enclaves independentes, dedicados à "pirataria de dados", ou outros tipos de enclaves, como os verdes e sociais-democratas e os de trabalho-zero, passando por zonas anarquistas liberadas etc. Assim, o autor define a economia de informação que sustenta essa diversidade como rede ${ }^{5}$.

Bey refuta a premissa de que a liberdade só será alcançada quando for dada a todos os seres humanos. Tendo por base o que aprendeu a respeito das histórias das ilhas de rede (do passado e do futuro), considera que há evidências suficientes para "sugerir que um certo tipo de 'enclave livre' não é apenas possível nos dias de hoje, mas é também real" (Idem, p. 4). Partindo desse ponto, explica que toda sua pesquisa e especulações se forjaram ao redor do conceito de TAZ.

Ao mencionar sua descrença com relação às revoluções, uma vez que elas são sucedidas por situações piores do que as anteriores, Bey $(2019$, p. 6) aponta que a TAZ é uma opção que "pode fornecer a qualidade do enlevamento associado ao levante sem necessariamente levar à violência e ao martírio". E assim define:

A TAZ é uma espécie de rebelião que não confronta o Estado diretamente, uma operação de guerrilha que libera uma área (de terra, de tempo, de imaginação) e se dissolve para se re-fazer em outro lugar e outro momento, antes que o Estado possa esmagá-la. Uma vez que o Estado se preocupa primordialmente com a Simulação, e não com a substância, a TAZ pode, em relativa paz e por um bom tempo, "ocupar" clandestinamente essas áreas e realizar seus propósitos festivos (BEY, 2019, p. 6).

Após considerar que algumas TAZ possam ter durado por gerações, Bey (2019) afirma que, por sua característica de invisibilidade, é uma tática perfeita para um momento em que o Estado é onipresente e poderoso, mas com rachaduras e fendas. Por isso, seu ataque feito às estruturas de controle (as ideias) e a defesa baseada na invisibilidade e invulnerabilidade evitam a violência do Estado. "A 'máquina de guerra nômade' conquista sem ser notada e se move antes do mapa ser retificado" (Idem, p. 7). Trata-se de um conceito sofisticado e convergente com alguns dos princípios de Lacoste a respeito do

\footnotetext{
${ }^{5}$ Santos, afirma ser possível reconhecer através das redes "três tipos ou níveis de solidariedade, cujo reverso são outros tantos níveis de contradições. Esses níveis são o nível mundial, o nível dos territórios dos Estados e o nível local." (SANTOS, 2008, p. 270).
} 
conhecimento do espaço, inclusive em uma linguagem cartográfica da qual Bey se utiliza no avançar dos capítulos.

É assim, no conjunto de distintas utopias, que se pode trazer outro conceito que se somará às reflexões traçadas até aqui. Michel Foucault (2013, p. 12) parte da afirmação de que “o corpo humano é o ator principal de todas as utopias”. Ele considera que cada máscara, maquiagem, tatuagem, vestimentas é a invocação das forças utópicas do embelezamento, do sagrado, dentre outras manifestações, no lugar que é o próprio corpo. No entanto, para ele, essas utopias se manifestam no tempo e no espaço na forma de heterotopias ${ }^{6}$.

Ha países sem lugar e histórias sem cronologia; cidades, planetas, continentes, universos, cujos vestígios seria impossível rastrear em qualquer mapa ou qualquer céu, muito simplesmente porque não pertencem a espaço algum. Sem dúvida, essas cidades, esses continentes, esses planetas nasceram, como se costuma dizer, na cabeça dos homens, ou, na verdade, no interstício de suas palavras, na espessura de suas narrativas, ou ainda, no lugar sem lugar de seus sonhos, no vazio de seus corações; numa palavra, e o doce gosto das utopias. No entanto, acredito que há - em toda sociedade - utopias que têm um lugar preciso e real, um lugar que podemos situar no mapa; utopias que têm um tempo determinado, um tempo que podemos fixar e medir conforme o calendário de todos os dias. É bem provável que cada grupo humano, qualquer que seja, demarque, no espaço que ocupa, onde realmente vive, onde trabalha, lugares utópicos, e, no tempo em que se agita, momentos ucrônicos (FOUCAULT, 2013, p. 19).

Poder-se-ia, assim, vislumbrar a emergência nos lugares das heterotopias convergentes de utopias dos corpos, para que, reunidos em suas zonas autônomas distintas, possam organizar uma bandeira de luta catalisadora das forças? Talvez, um dos fracassos das tentativas de unificação de lutas seja o desprezo pelas individualidades; mais do que isso, o desrespeito às muitas possibilidades necessárias a uma humanidade complexa e plural.

Não será possível convergir lutas, enquanto os distintos grupos gravitarem na dualidade do bem e do mal, do preto e do branco. Necessita-se avançar na construção que considere as distintas realidades, mas que, respeitando as diferenças, enfoque a causa em comum. Isso não poderá ocorrer em um movimento em que verdades sejam impostas, configurando as forças internas que geram fragmentações nos movimentos, algo similar ao que bem afirmou Albert Camus (2014, p. 39): "A necessidade de ter razão marca de uma inteligência grosseira".

Essa premissa vale para todos os lados, se a intenção for congregar. As pautas que põem um grupo a combater outro tendem a separar e/ou gerar reações. Essas lutas são legitimas e não devem ser suprimidas, mas os distintos grupos podem convergir na ideia de que a sociedade repleta de injustiças pode ter sua estrutura modificada se unirem forças em prol de uma causa comum.

Esse pensamento pode ser estendido a qualquer tema, mas precisa ser ampliado no sentido de aceitar que, para muitos, não haverá interesse em mudanças na estrutura do sistema. Essa reflexão não se aplica a estes, exceto pelo fato de que não precisam ser combatidos nem convencidos. Na verdade, supondo que a ideia em construção seja posta em operação, três batalhas grandiosas já demandarão bastante energia: a batalha pessoal, a confluência das unidades para criação de suas distintas heterotopias e a convergência

\footnotetext{
${ }^{6}$ Posteriormente Foucault abandona o termo.
} 
dos grupos em uma causa comum. Algo similar é pensado por Santos, em sua proposta de articulação social:

A partir do país como federação de lugares será possível, num segundo momento, construir um mundo como federação de países.

Trata-se, em ambas as etapas, de uma construção de baixo para cima cujo ponto central é a existência de individualidades fortes e das garantias jurídicas correspondentes. Base geográfica dessa construção será o lugar, considerado como espaço de exercício da existência plena (SANTOS, 2003, p. 113-114).

Ainda que por propostas diferentes, é perceptível a existência de similaridades na necessidade de percepção e articulação das diferentes escalas de organização. Partindo das premissas que apontam a necessidade de uma revolução integral pessoal, para desse ponto ir para o exterior, e de outras premissas que consideram o lugar como a primeira escala de atuação, para daí articular outros níveis, chegou-se à concepção das três escalas de revolução.

\subsection{As três escalas de revolução}

Tomando como ponto de partida que o instrumento de percepção do exterior e do interior é o corpo, considera-se que este é a menor unidade geográfica. "A 'globalização' é o mais macro de todos os discursos que temos à disposição, enquanto o discurso do corpo é o mais micro do ponto de vista da compreensão do funcionamento das sociedades [...]" (HARVEY, 2004, p. 30).

Consideremos a existência de três escalas de revolução: a do corpo, a do lugar e a das articulações em redes. Elas não se excluem, mas, caso não sejam formuladas da base para o topo, levarão inexoravelmente qualquer movimento ao fracasso ${ }^{7}$. A menor de todas as escalas, a do corpo, presume sua relação com o mundo interior e o mundo exterior. Partindo dela, vem a escala das relações diretas, ou a dos lugares nos quais os corpos se encontram (ainda que virtualmente); por fim, a escala que articula os lugares, não como uma continuidade territorial, mas como redes.

Enquanto o indivíduo não revolucionar a estrutura de seu país psicológico, ainda que bem-intencionado, ao congregar reproduzirá os princípios sistêmicos do qual estará impregnado. Existem métodos que apontam caminhos para essa revolução da consciência ${ }^{8}$, no entanto este texto não objetiva tratar desse tema, exceto no aspecto de enfatizar que carregamos em nossa estrutura psíquica aquilo que recebemos de influência do mundo exterior, assim como construímos um mundo a partir da psicologia que carregamos.

Apenas a título de exemplificação, considerando o que afirma Santos (2003) a respeito da sociedade do consumo, da imagem e da competição que compõe o tripé da globalização, é possível questionar: quem são as unidades corpóreas que competem entre si, que consomem de forma alienada e que ostentam ou buscam aparentar o que não são?

\footnotetext{
7 A respeito dessa afirmação, um exemplo é descrito por Manoel de Sousa (2003, p. 30) ao analisar os motivos que, segundo Rossi, levaram as comunidades utópicas do século XIX ao fracasso, dentre os quais muitos poderiam "ser atribuídos à condição humana [...] os condicionalismos psicológicos e culturais dos participantes dessas experiências." O autor enfatiza que: "Superar as tendências agressivas, egoístas, o poder, o ciúme, ou o espírito de concorrência, num grupo humano é bem mais complexo que a adopção de uma engenharia falansteriana ou de um ideal libertário".

8 Por exemplo, no livro Revolução da Dialética, de Weor (2018), o autor, por uma linguagem esotérica, traz importantes reflexões a respeito da necessidade do autoconhecimento e afirma que de nada serve pretender conhecer o mundo se não se sabe nada a respeito de si mesmo.
} 
Como mencionado no paralelo do mito da caverna, antes do retorno para entregar a mensagem visando romper os grilhões do sistema, é necessário ao mensageiro se autoprovocar, receber o choque de consciência, chegando a despertar para a dura realidade de que está adormecido e escravizado por esse mesmo sistema. Cabe ressaltar que esse despertar precisa vir com a prática, na mudança de condutas, como pequenos ensaios que forneçam vivência para a construção das articulações. Essas experiências independem do todo, mas cada qual em seu estágio pode permutar entre si o que for necessário, de informações a objetos.

A segunda escala requer um complemento do que já foi mencionado: a liberdade de formas e motivos pode ser a chave para a união de iguais que busquem a sua utopia enquanto grupo. O ser humano busca a felicidade, e, ainda que em um primeiro momento precise encontrá-la em si, é quando sai ao encontro do outro que essa busca se realiza.

Em nosso estudo sobre as migrações em Salvador (RIBEIRO, 2018), foi possível identificar que a força que move o indivíduo, a causa que o leva a migrar, é a busca pela felicidade, ainda que justificada por diferentes razões. Nas entrevistas realizadas, percebeu-se que havia, tal como nas leis de repulsão e atração de Ravenstein (1885, 1889), um padrão perceptível nas falas dos imigrantes. Se, por um lado, o seu lugar de origem não os deixava em plenitude, por outro eles buscaram no seu destino a utopia que guardavam em seus países psicológicos. Para uns, a realização pela música; para outros, as praias; para alguns, a festividade tropical; para muitos, as fugas de seus problemas, em alguns casos o amor.

Esses migrantes e imigrantes, longe de seus lugares de origem, forçados a romper com seus paradigmas, associaram-se com outros iguais e formaram verdadeiras congregações (ou, na linguagem de Bey, zonas autônomas temporárias), cada qual em seus objetivos. Entre muitos exemplos, surgiram bandas de maracatu com pessoas de diversas partes do mundo; um bloco de carnaval só de japoneses; uma casa onde latinos de toda a América se reuniam para tocar e dançar música latina; espaços de música afro-baiana, onde soteropolitanos e estrangeiros se misturavam, interagiam, formavam amizades, amores, laços que se fortaleciam mesmo depois distanciados pelo oceano; religiosos que buscavam viver a utopia de seus deuses na Terra, trabalhando pelos mais necessitados e buscando a paz em seus redutos; grupos de intelectuais (ou não) que se reuniam nos bares para conversar sobre os mais variados temas.

Saindo do exemplo de Salvador, é possível identificar comunidades que se formam com diferentes finalidades, cuja síntese é a busca pela felicidade, a construção de sua utopia. Grupos religiosos que se isolam em pequenos feudos, nos quais as normas, muitas vezes, beiram um socialismo cristão, ou budista, ou de religiões de matrizes afro-indígenas, ao mesmo tempo que comunidades com diferentes filosofias também se formam: nudistas, naturalistas, vegetarianos, carnívoros, permacultores, rurais, urbanos, comunidades tradicionais, os que veem potência nas favelas e periferias, os que buscam os clubes sociais mais variados...

Cada qual não precisa impor sua verdade, seu caminho ao outro. Não é necessário proselitismo para convencer que tal ou qual forma é a correta ou a melhor. Ambos podem e devem existir para o bem da diversidade sociocultural, sem que para isso precisem se anular. No entanto, é preciso que cada uma das particularidades perceba que, por mais 
que busquem sair do sistema, sofrerão direta ou indiretamente a influência dele ${ }^{9}$. Por isso, faz-se necessário caminhar para a terceira escala da revolução.

Na terceira escala, essas potências articuladas enquanto pequenas células somam forças em prol de uma causa comum. No momento em que as pautas divergentes deixarem de lado suas diferenças e unificarem uma luta que atinja a base do sistema, o caminho para uma mudança estrutural pode ser fortalecido. Hoje, o meio técnico permite que essas particularidades se articulem enquanto rede.

Seria essa uma utopia? Certamente é uma ideia em construção, impulsionada a partir dos diálogos e reflexões nas aulas. Haveria nela a convergência entre forma e processo? Possivelmente entre muitas formas e processos que, como eixos na engrenagem de um sistema em construção, iriam se unir para girá-lo em uma nova roda. No entanto, ainda cabe o debate a respeito das estratégias.

\subsection{Imperialismo empresarial $x$ movimentos sociais}

Em O Novo Imperialismo (2005), Harvey delineia como o domínio territorial imperialista dos Estados Unidos é exercido. Também explana a respeito das ações das grandes corporações, que possuem vantagens em sua lógica organizacional com relação ao Estado. Não precisando de uma presença física em um território específico, as empresas se movimentam pelo planeta conforme as suas necessidades estratégicas e, mais do que isso, sendo detentoras do capital, moldam os territórios e o espaço geográfico de acordo com os seus desejos.

A vantagem das corporações empresariais em relação ao Estado também está no aspecto temporal, uma vez que elas podem traçar metas de longo prazo, algo que se torna mais complexo nos sistemas democráticos (principalmente nas democracias frágeis). $\mathrm{O}$ autor explica que esses sistemas de governo não conseguem ter uma continuidade de planejamento; assim, as ações precisam ser pensadas e executadas para o período de gestão, que geralmente é de quatro a seis anos.

Uma outra e fundamental força das corporações empresariais é que elas, ao dominarem o capital no sistema capitalista, possuem de fato o poder e, assim, valem-se do aporte financeiro para impor seus interesses nos territórios do mundo. O que se evidencia é que o Estado atua como uma mão executora dos desejos dos bancos e das corporações internacionais.

Como consequência, o espaço geográfico é moldado pela aplicação do capital para transformar as estruturas de modo a se tornarem mais receptivas ao sistema e, ao mesmo tempo, pela máquina ideológica, que tem como principal aliada as mídias e agora as redes sociais. Contrapondo-se a essa estrutura de dominação, surgem os movimentos sociais com as distintas demandas que fazem enfrentamento às opressões do sistema capitalista. Para esta breve reflexão, ainda que não sendo a mesma coisa, serão consideradas as organizações não governamentais (ONGs) como instrumentos de articulação desses movimentos.

O surgimento de ONGs com diversas finalidades apontou um caminho em que a absorção dos aspectos territorial e temporal das grandes instituições financeiras e empresariais pode ser utilizada como estratégia para articulações populares, confluindo

9 Seja o rio ou o ar poluído, o plantio transgênico, que, mesmo não consumido nas prateleiras, pode comprometer culturas vulneráveis, ou as ações e inações políticas, ou até mesmo um vírus, uma pandemia. 


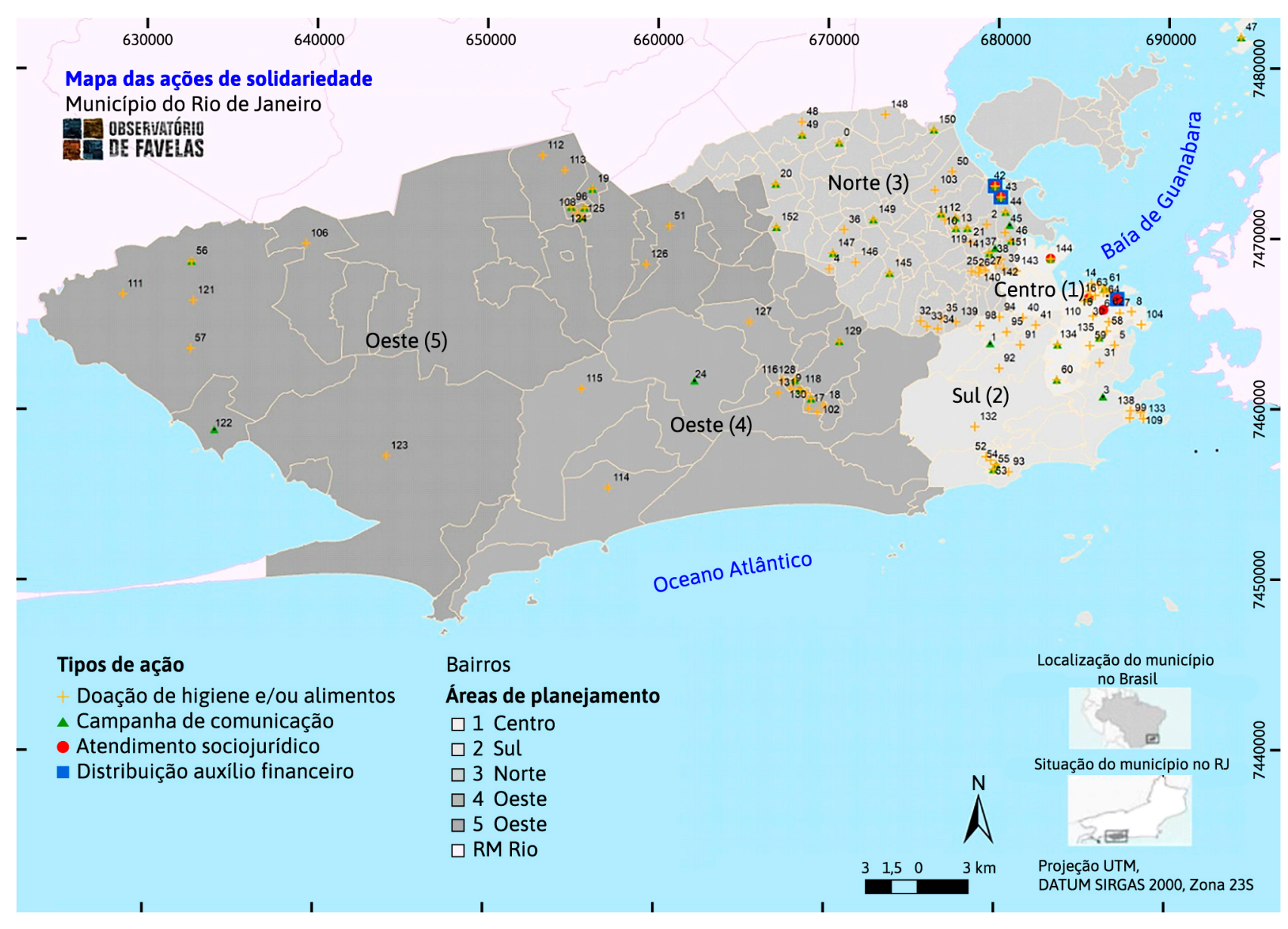

Figura 1 - Tipos de ações de solidariedade no município do Rio de Janeiro em 2020.

Fonte: Observatório de Favelas (2020), Mapa elaborado pelo autor. Base cartográfica; Instituto Pereira Passos (2020).

energia para combater as desigualdades do sistema. Porém, é certo que muitas ONGs não cumprem esse papel. Ao mesmo tempo, com algumas exceções, a necessidade de captação de recursos compromete uma parcela do poder político dessas organizações. Por fim, ainda que importante, o enfoque em suas pautas não permite espaço para articulações maiores ${ }^{10}$. No final, inseridas no sistema, as ONGs terminam compondo uma parte dele; mesmo assim, nelas se encontra uma potência para o terceiro momento da revolução.

Um exemplo da potência dessas organizações foi observado no trabalho realizado para a ONG Observatório de Favelas, em 2020, no qual se analisaram, em 10 edições, o efeito da Covid-19 no Rio de Janeiro e o contraste do impacto da pandemia entre as áreas periféricas e nobres da cidade. Entre os resultados, observaram-se a distribuição dos equipamentos de saúde no município do Rio de Janeiro, os mapas de contágio por bairro e as distintas análises da proliferação da Covid-19 considerando os perfis populacionais (OBSERVATÓRIO DE FAVELAS, 2020). Também se fez um estudo sobre os fluxos de trabalho e as relações regionais entre a capital e o estado fluminense. Contudo, a última edição apontou uma mensagem de esperança, com o mapeamento das ações de solidariedade no Rio de Janeiro (Figura 1).

${ }^{10}$ Existem ONGs que tentam cumprir com esse papel, a exemplo da Politize, que tem por objetivo "formar uma geração de cidadãos conscientes e comprometidos com a democracia” (POLITIZE, 2021). 
Com o contexto da pandemia, apesar de cada uma das organizações mapeadas possuir diferentes finalidades e raios de ação, no momento em que elas perceberam a existência de um inimigo comum (Covid-19), as forças delas se voltaram para o combate do vírus e seus desdobramentos, econômicos, sociais e psicoemocionais. Cada uma dessas unidades, com suas pautas próprias, atuaram quase sempre de forma isolada contra um alvo em comum. Se existe um objetivo comum a todos, é possível unir as forças para combatê-lo.

O caso da Covid-19 foi extremo, por isso a percepção da prioridade do seu combate foi, antes de tudo, uma necessidade. Assim, chega-se ao ponto de partida. Apenas quando perceberem que, mesmo lutando contra o sistema, o paliativo isolado termina por compô-lo, é que as unidades tentarão enfocar uma causa comum.

As ONGs possuem um potencial para isso, e algumas já buscam o fazer. A dualidade entre utilizar o sistema para combatê-lo e ser cooptado por ele é complexa e exige maior aprofundamento. No entanto, observa-se que, por meio delas, materiais de extrema qualidade para promover suas causas são elaborados e grupos sociais são articulados. Como aproveitar essa potência para combater a base estrutural do sistema hegemônico?

Quais são as possibilidades de convergir essas estratégias para uma articulação popular no intuito de, utilizando as mesmas armas dos detentores do poder ou talvez outras ainda mais sutis e sofisticadas, iniciar uma transformações nas estruturas tais como são? Existem exemplos na história que apontam ser possível fazer tal ação sem se deflagrar uma bala. A proposta de Bey a respeito da estratégia das TAZ não é a primeira e já foi realizada. Tomemos por base os preceitos de Thoreau, em A Desobediência Civil, traduzidos por Gandhi na conduta do Ahimsa.

\subsection{Ahimsa}

A não violência não consiste em renunciar a toda luta real contra o mal. A não violência, tal como eu a concebo, empreende uma campanha mais ativa contra o mal que a Lei de talião, cuja natureza mesma traz como resultado o desenvolvimento da perversidade. Eu levanto, frente ao imoral, uma oposição mental e, por conseguinte, moral. Trato de amolecer a espada do tirano, não cruzando-a com um aço mais afiado, mas defraudando sua esperança ao não oferecer resistência física alguma. Ele encontrará em mim uma resistência da alma, que escapará de seu assalto. Essa resistência primeiramente o cegará e em seguida o obrigará a dobrar-se. E o fato de dobrar-se não humilhará o agressor, mas o dignificará (Mahatma Gandhi).

O princípio da não violência apontado por Gandhi tem correspondência com os escritos de Thoreau, nos quais evoca a premissa de que o cidadão deve, antes de tudo, seguir a sua consciência e jamais desistir dela para se dobrar diante das injustiças do Estado ou de um legislador. "Na minha opinião devemos ser em primeiro lugar homens, e só então súditos” (THOREAU, 1849, p. 6).

Questionando as ações do governo dos Estados Unidos no século XIX, que, com o dinheiro dos contribuintes, fomentava a guerra com o México e a escravidão, o autor se nega a ser parte de um governo "que é também o governo do escravo" (Idem, p. 9). Thoreau comenta que, quando um país tem $1 / 6$ de sua população composta de escravos, e seu exército assalta e conquista outro país, "não é cedo demais para a rebelião e a revolução dos homens honestos" (Idem, p. 10). Por fim, critica os milhares de cidadãos que, contrários à escravidão e à guerra, nada faziam para findar ambas. 
Seguindo essa lógica, Thoreau formula a seguinte questão: "Existem leis injustas; devemos submeter-nos a elas e cumpri-las, ou devemos tentar emendá-las e obedecer a elas até à sua reforma, ou devemos transgredi-las imediatamente?" (Idem, p. 10). Para ele, o fundamental é não participar de forma alguma das misérias que condena.

O autor explica como uma revolução pacífica pode ocorrer caso cada indivíduo decida não manter os vínculos com o Estado, sendo levado à cadeia, de modo que essa conduta seja seguida por outros. "Quando o súdito negou a lealdade e o funcionário renunciou ao seu cargo, então a revolução completou-se" (Idem, p. 10). Para ele, o problema não estaria em pagar o imposto da estrada ou da manutenção da escola, uma vez que se busca ser um bom vizinho tal como um péssimo súdito.

Em seu relato, sobre a experiência de ter sido encarcerado por não pagar os impostos, comenta: "Vi que, apesar da grossa parede de pedra entre mim e os meus concidadãos, eles tinham uma muralha muito mais difícil de vencer antes de conseguirem ser tão livres quanto eu" (Idem, p. 30). E, na sequência, atesta que "O Estado nunca confronta intencionalmente o sentimento intelectual ou moral de um homem, mas apenas o seu corpo, os seus sentidos" (Idem, p. 31). Thoreau conclui que o Estado apenas tem maior força física, mas não de honestidade ou gênio superior.

Esse princípio da recusa em compactuar com as injustiças do Estado foi praticado por figuras como Mahatma Gandhi, para alcançar a independência da Índia e Paquistão, e Martin Luther King, na luta pelos direitos civis e o fim da segregação racial nos Estados Unidos.

Até que ponto transferimos nossa responsabilidade política para um representante A, $\mathrm{B}$ ou $\mathrm{C}$ e nos conformamos em esperar os resultados de suas ações, que, como se sabe, por mais bem-intencionadas que sejam, estarão cooptadas por toda máquina do sistema? Observa-se, na atual conjuntura política nacional, a triste (e dificilmente reversível) polarização da população em torno de figuras políticas. Assim, enquanto divididos lutam entre si defendendo as bandeiras dos representantes, fazem vistas grossas aos erros de seus líderes ao mesmo tempo que atacam as debilidades do alheio.

Retomando as ideias de Thoreau e os exemplos de Gandhi e Martin Luther King, ressalta-se que um possível meio para sair da polarização é abandonar as figuras dos heróis salvadores e articular a luta em torno da causa. Enquanto personificarmos em um messias a nossa salvação, estaremos fadados a cair no abismo.

No entanto, considerando outra conjuntura livre das polarizações, o que ocorreria se, batalha por batalha, a sociedade articulada começasse a lutar por seus anseios, negando-se a cooperar com o sistema e organizando-se em torno do que os une? Valem as perguntas de Thoreau: "Será que a democracia tal como a conhecemos é o último aperfeiçoamento possível em termos de construir governos? Não será possível dar um passo a mais no sentido de reconhecer e organizar os direitos do homem?" (Idem, p. 46).

Em outro contexto, Engels e Marx (1999) consideram que, uma vez organizado e utilizando a sua supremacia política, o proletariado arrancará "pouco a pouco todo capital à burguesia, para centralizar todos os instrumentos de produção nas mãos do Estado, isto é, do proletariado organizado em classe dominante [...]" (ENGELS; MARX, 1999, p. 42).

O que explica que, independentemente da existência de uma parcela alienada da população, haja uma massa de pessoas que, apesar de insatisfeitas, aceitam resignadamente a ordem das coisas? "É o medo que nos fez escravos e que nos mantêm nesta condição. 
Baixamos a cabeça frente aos donos do mundo, aceitamos esta vida de humilhação e de miséria somente por medo" (BRIENT, 2020, p. 11).

Assim como Thoreau, Brient (2020, p. 12) considera que a força dos governos não deriva de seus policiais, mas de nosso consentimento, e conclui "o silêncio da maioria dos escravos frente a essa repressão está justificado na aspiração mediática e política que nega o conflito existente na sociedade atual".

Como já afirmado, Marx e Engels, Thoreau e Brient, Santos e Harvey, Weor e Platão, entre outros, não escreveram as mesmas coisas, não apontaram caminhos e soluções iguais, nem sequer formularam teorias compatíveis. No entanto, o estudo de seus textos nos permitiu refletir e perceber que, enquanto houver injustiça no planeta, é preciso manter a chama revolucionária acesa, para que não nos conformemos em sobreviver, mas que busquemos a nossa utopia na Terra.

\section{Considerações finais}

Nos cinco meses em que ocorreram os encontros referentes à disciplina "Geografia dos Espaços Alternativos, outras possibilidades, novas esperanças", notou-se o impacto que esses estudos causaram no grupo. A tônica de desconstruir as ideias estabelecidas para depois buscar por alternativas gerou inquietudes, muitas vezes relatadas pelos alunos.

Trabalhar com autores que seguiam linhas distintas e até mesmo contrárias contribuiu para o enriquecimento das percepções de como o mundo pode ser pensado em múltiplas perspectivas. Qual dessas é a certa? Qual é a errada? Buscou-se refutar as ideias bem-aceitas pelo grupo e, quando criticadas, procurou-se defendê-las, mantendo, assim, o debate em evidência.

Ainda que neste texto o enfoque tenha sido dado às ideias dos autores, outros aspectos também foram analisados nas aulas. Por exemplo, sempre ao estudar um livro, buscou-se a sua contextualização espaço-temporal e, com isso, percorreu-se em segundo plano por diferentes espaço-temporalidades, evidenciando que outros momentos históricos já existiram e que, assim como agora, os autores de seus tempos se insurgiram diante de uma visão pessimista e conformista da situação vivenciada e buscaram lutar por transformações.

Com estudos como a Republica de Platão escrita no século IX a.C., seguido pela Riqueza das Nações de Adam Smith publicado em 1776, O Manifesto do Partido Comunista em 1848, A Desobediência Civil em 1849 e o de autores contemporâneos foi possível observar alguns dos diferentes momentos experimentados pela humanidade.

O percorrer por essa história veio demonstrar que, ainda que o mundo continue inflado de injustiças, ele vem sendo moldado graças aos que não aceitaram as ordens das coisas assim como são. Vale ressaltar que a ideologia burguesa de agora se consolidou pautada na utopia burguesa de outrora.

Muitos foram os desafios encontrados para a transcrição da experiência vivenciada em um relato. A terceira seção, na qual se compartilhou uma parcela dos debates, apresentou uma amostra das ideias de cada livro, e o caminho para tal se deu pelo diálogo com o pensamento dos autores. Com isso, foi inevitável não imprimir um pouco do ideal utópico pessoal que se avivou no avançar das reflexões. 
Em um momento histórico tenebroso, em que se percebe o desânimo dos pares intelectuais perante a imponência do sistema vigente, a Geografia dos Espaços Alternativos ecoa como um grito romântico de guerra, fincando a bandeira da esperança para lembrar a todos que, por mais impossível que possa parecer a construção de um mundo melhor, é preciso manter a posição e continuar lutando. Ela busca também a reflexão sobre a necessidade de buscarmos novas estratégias.

Assim, ainda que muitas vezes o autor deste texto tenha se sentido ingênuo em suas ideias, ele prefere ser criticado por propostas a se conformar com a inércia. A "Geografia dos Espaços Alternativos, outras possibilidades, novas esperanças” vem, então, para provocar as reflexões a respeito de outras possibilidades para a construção de um mundo mais justo e com a finalidade de inflamar o coração dos que possam se sentir tocados a renovar suas esperanças.

\section{REFERÊNCIAS}

BEY, H. TAZ: zona autônoma temporária. São Paulo: Veneta, 2019.

BRIENT, J.-F. Da servidão moderna. 2009. Disponível em: <http://www.delaservitudemoderne.org/ Documents/daservidaomoderna.pdf $>$. Acesso em: jun. 2020.

CAMUS, A. A esperança do mundo. São Paulo: Hedra, 2014.

CASTRO, J. Geografia da fome o dilema brasileiro: pão ou aço. Rio de Janeiro: Civilização Brasileira, 2011.

ENGELS, F.; MARX, K. Manifesto do partido Comunista. RokectEdition, 1999. Versão para e-book.

FOUCAULT, M. O corpo utópico: as heterotopias. São Paulo: n-1 Edições, 2013.

HARVEY, D. Espaços de esperança. São Paulo: Loyola, 2004.

HARVEY, D. O Novo Imperialismo. São Paulo: Loyola, 2005.

INSTITUTO PEREIRA PASSOS - IPP. DATA.RIO. Informações sobre a cidade. 2020. Disponível em: $<$ https://www.data.rio/>. Acesso em: 24 ago. 2020.

LACOSTE, Y. A geografia: isso serve, em primeiro lugar, para fazer a guerra. Campinas: Papirus, 2012.

MORUS, T. Utopia. 2001. Disponível em: <http://www.ebooksbrasil.org/adobeebook/utopia.pdf >. Acesso em: 24 ago. 2020.

OBSERVATÓRIO DE FAVELAS - OF. Quilombismo e lideranças femininas: o protagonismo das favelas no enfrentamento à pandemia. 10. ed. Rio de Janeiro, 2020. (Mapa Social do Corona).

ORGANIZAÇÃO PAN-AMERICANA DA SAÚDE - OPAS. Folha informativa COVID-19. Escritório da OPAS e da OMS no Brasil, 2020. Disponível em: <https://www.paho.org/pt/covid19>. Acesso em: 24 set. 2020.

PLATÃO. A República. Tradução Pereira Maria H. R. 9. ed. Fundação Calouste Gulbenkian, 1949.

POLITIZE. 2021. Disponível em: <https://www.politize.com.br/>. Acesso em: 24 set. 2020.

RAVENSTEIN, E. G. The laws of migration. Journal of the Royal Statistical Society, London, v. 52, n. 2, p. 241-305, 1889.

RAVENSTEIN, E. G. The laws of migration. London: Blackwel Publishing for the Royal Statistical Society, 1885.

RIBEIRO, D. A. Migrações para o Eixo Pelourinho Santo Antônio. 2018. Tese (Doutorado)-Universidade Federal da Bahia, Salvador, 2018.

SANTOS, M. A natureza do espaço: técnica e tempo, razão e emoção. 4. ed. 4. reimpr. São Paulo: Edusp, 2008.

SANTOS, M. Por uma outra globalização: do pensamento único à consciência universal. 10. ed. Rio de Janeiro: Record, 2003.

SMITH, A. A riqueza das nações. São Paulo: Nova Cultural, 1996.

SOUSA, M. As comunidades experimentais, como alternativas ao capitalismo. In: Utopia. 16. ed. Lisboa, 2003.

THOREAU, H. Desobediência civil. 1849. Versão para e-book. 
TZU, S. A arte da guerra. Tradução do chines para o ingles: Samuel B. Griffith, Ingles para o portugues: Gilson Cesar Cardoso de Souza, Klaus Brandini, Gerhardt. 7. ed. Rio de Janeiro: Paz e Terra, 1996.

WEOR, S. A. A revolução da dialética. Camanducaia: Gnosis Brasil, 2018.

WEOR, S. A. Educação fundamental. Camanducaia: Gnosis Brasil, 2019.

SOBRE O AUTOR

Daniel de Albuquerque Ribeiro (RIBEIRO, D. A.) Pós-doc no Programa de Pós-Graduação em Geografia da Universidade Federal Fluminense, em Campos dos Goytacazes. Membro do Grupo de Estudos e Pesquisas de Geografia Histórica (Geohistórica). 
SEÇÃO II

\section{Geografia \\ histórica}




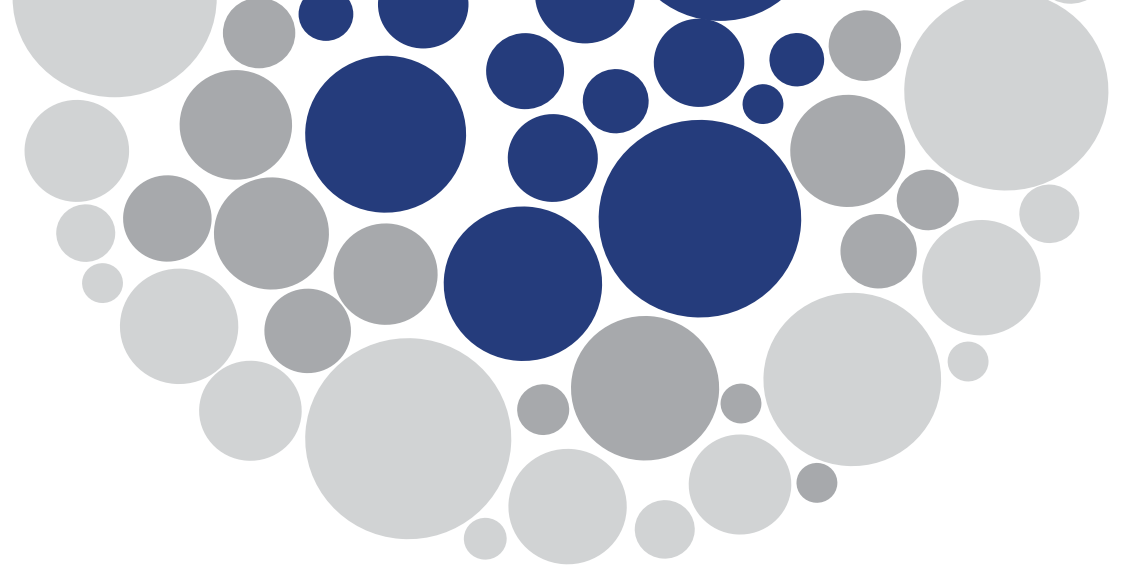

\title{
Geografia Histórica como método
}

\begin{abstract}
Glauco Bruce Rodrigues ${ }^{a}$
a Departamento de Geografia, Programa de Pós-Graduação em Geografia da Universidade Federal Fluminense - Campos dos Goytacazes (UFF/Campos). Núcleo de Estudos sobre o Território e Conflitos Sociais. E-mail: glauco_bruce@id.uff.br.
\end{abstract}

No livro Geography and History: bridging the divide, o geógrafo Alan Baker (2003) elabora sete princípios gerais sobre a Geografia Histórica, dos quais dois são mais relevantes para nossa discussão. O primeiro afirma que a Geografia Histórica questiona o passado, assim como a História ${ }^{1}$. O segundo afirma que a Geografia Histórica se dedica, fundamentalmente, à mudança geográfica através do tempo². Tais princípios, elaborados no final do livro, buscam realizar uma síntese teórica que permita ao autor circunscrever a singularidade da Geografia Histórica e, dessa forma, defendê-la como um campo de pesquisa específico no interior da disciplina. Em outras palavras, os sete princípios funcionam como balizadores teóricos que, devidamente articulados, justificam e legitimam pensar a Geografia Histórica como um campo específico e singular da Geografia, com autonomia própria. De forma sintética, os dois princípios que destacamos são exatamente aqueles que seriam, de maneira efetiva, os traços definidores e, portanto, distintos e próprios deste campo, caracterizado pelo estudo de geografias do passado ou por processos de transformações do espaço, do lugar, da região, da paisagem ou do território ao longo do tempo. De qualquer forma, o traço que caracteriza a diferenciação e singulariza a Geografia Histórica é o estudo do passado.

Durante o III Encontro Nacional de História do Pensamento Geográfico e I Encontro Nacional de Geografia Histórica, realizado na Universidade Federal do Rio de Janeiro, em novembro de 2012, o professor Pedro Vasconcelos apresentou um trabalho intitulado

\footnotetext{
1 "The first of my seven principles is that historical geography, like history, asks questions about the past" (BAKER, 2003, p. 209, grifos do autor).

2 "My fourth principle is that historical geography is essentially concerned with geographical change through time" (BAKER, 2003, p. 215, grifos do autor).
} 
Geografia Histórica: campo disciplinar e questões de pesquisa $a^{3}$ Partindo de um abrangente levantamento bibliográfico, o autor coloca como ponto de partida de sua reflexão a própria definição do que seria a Geografia Histórica, chamando a atenção para a diversidade de definições e perspectivas encontradas ao longo do tempo, em que a Geografia Histórica foi definida, por exemplo, como "a descrição de uma área no passado" (HETTNER, 1898 apud VASCONCELOS, 2012, p. 1), “o estudo geográfico de qualquer período do passado" (MITCHELL, 1954 apud VASCONCELOS, 2012, p. 1), "o estudo das mudanças geográficas através do tempo" (DARBY, 1954 apud VASCONCELOS, 2012, p. 1), o “estudos das geografias do passado" (BUTLIN, 1993 apud VASCONCELOS, 2012, p. 1), "toda a geografia conjugada a toda história, nas preocupações e os métodos mais variados dessas disciplinas" (PITTE, 2005 apud VASCONCELOS, 2012, p. 1) e, finalmente, "como o estudo geográfico do passado, destacando o interesse principal é com as mudanças geográficas através do tempo" (BAKER, 2003 apud VASCONCELOS, 2012, p. 2). Podemos observar que as definições, em sua maior parte, são tentativas de estabelecer a Geografia Histórica como um campo da disciplina dedicado, principalmente, ao estudo de geografias do passado e mudanças de caráter geográfico através do tempo.

Em um artigo de revisão, Patrício Carneiro (2016) nos apresenta um amplo panorama da Geografia Histórica entre os séculos XIX e início do XXI, destacando o esforço realizado para a constituição de um campo específico dentro da Geografia. Entre as décadas de 1940 e 1960, segundo o autor, criaram-se, efetivamente, as bases para a instituição da Geografia Histórica como um campo a partir dos esforços de geógrafos como Carl Sauer, Henry Darby, Andrew Clark e Donald Meinig: "Esses pesquisadores lutaram pela incorporação do tempo nas análises geográficas e mostraram que pensar historicamente é parte essencial do ato de fazer geografia humana" (CARNEIRO, 2016, p. 61). A forma como incorporaram a história e o tempo pode ser resumida como o estudo de geografias do passado e das transformações geográficas ao longo do tempo.

No texto que funda a moderna Geografia Histórica, publicado no Annals of the Association of American Geographers, em 1941, Carl Sauer propõe pensar na Geografia Humana como Geografia Histórica-Cultural (SAUER, 2004, p. 8). Tal formulação pode nos dar a ideia da dimensão da ambição dos geógrafos que se dedicaram à afirmação da Geografia Histórica como campo.

Em trabalho recente, Carlo Eugênio Nogueira (2019) também chama a atenção para o predomínio (e não exclusividade) da concepção de que a Geografia Histórica constitui um campo caracterizado pelo estudo das geografias do passado, apontando, a partir desse diagnóstico, para algumas transformações pelas quais esse campo estaria passando:

Desse modo, há um deslocamento do objeto de estudo da Geografia Histórica, com a atenuação do desejo cego pela reconstrução da materialidade das geografias passadas e o reconhecimento da importância das representações nas ações de apropriação e transformação do espaço. Isto é, valoriza-se a análise do lugar dos discursos geográficos na elaboração de projetos que embasam políticas que visam ordenar a construção dos territórios, em um registro que se aproxima de um exame geográfico da experiência histórica (Zusman, 2000) (NOGUEIRA, 2019, p. 2).

\footnotetext{
${ }^{3} \mathrm{O}$ trabalho, infelizmente, não foi publicado, porém o texto apresentado foi repassado pelo próprio autor.
} 
Os cinco autores que nos auxiliam a colocar a questão não deixam dúvidas: a Geografia Histórica, em toda sua diversidade e complexidade, é pensada, de forma majoritária, como um campo específico e autônomo da Geografia.

A primeira questão a se colocar refere-se, exatamente, ao processo de institucionalização da Geografia Histórica como um campo particular de pesquisa na Geografia. O que constituiu um campo de pesquisa em uma disciplina, no caso em questão, a Geografia? Um campo é constituído por um conjunto relativamente restrito e delimitado de questões, constituídas por fenômenos e processos que possuem certa identidade e significativa articulação, que nos permitem a construção limitada de um certo número de objetos. Em outras palavras, um campo é caracterizado por um conjunto de processos e fenômenos relativamente semelhantes e que se distinguem de outros campos pela diferença dos conteúdos. Assim, Geografia Urbana, Geografia da População, Geografia da População, Geografia dos Ativismos Sociais são campos específicos de pesquisa em Geografia, porque são constituídos por fenômenos e processos com forte identidade entre si, com um conjunto específico de questões que os diferenciam uns dos outros. Evidentemente, os campos dialogam, e seus processos, fenômenos, questões e objetos perpassam uns pelos outros, no entanto é possível circunscrever a singularidade de cada um, seu cerne, seu conteúdo fundamental.

Um excelente exemplo de definição de um campo pode ser encontrado no texto de Allen Scott e Michael Storper (SCOTT; STORPER, 2018), no qual os autores se propõem a explicitar um conceito de urbano para que possa servir como elemento definidor de um campo específico de pesquisa, no caso em tela, os estudos urbanos. Eles colocam a questão da seguinte forma:

Dito isto, nosso objetivo geral neste artigo não é envolver-se em uma crítica detalhada da literatura e, certamente, não negar que as cidades exibem uma variação empírica considerável ao longo do tempo e do espaço ou que as cidades podem ser estudadas de forma aproveitável como casos únicos. Em vez disso, estamos preocupados em tentar construir um conceito geral do urbano e do processo de urbanização que acreditamos poder ajudar a trazer um vocabulário comum aos debates que proliferam dentro deste campo. Qualquer conceito desse tipo também contribuirá para a pesquisa sobre as cidades, ao nos fornecer indicadores que facilitam a tarefa crucial de demarcar a lógica interna da urbanização diferenciando-a de outros processos sociais. Assim, pensamos que nossa abordagem teórica realmente ajuda a iluminar em vez de distorcer as particularidades de cidades específicas e de grupos de cidades. Pelo menos parte da cacofonia na literatura de estudos urbanos pode, em parte, ser rastreada ao fracasso dos pesquisadores em serem claros sobre essas questões de definição e demarcação (SCOTT; STORPER, 2018, p. 9, grifos nossos).

Os autores colocam a necessidade da explicitação clara e lógica da demarcação e explicitação do campo de pesquisa. Tal campo se constitui a partir da seleção de um certo número de questões, processos e fenômenos que possuem forte identidade e inter-relações estruturais e conjunturais. É essa explicitação que justifica e legitima a seleção de dados empíricos que sustentam a construção de objetos de pesquisa que serão utilizados para a análise das questões centrais. Assim, a demarcação de um campo demanda a formalização lógica dos elementos centrais que o singularizam e o diferenciam de outros. Dessa forma, por maior que seja a diversidade teórica e temática, a comunidade de pesquisadores de determinado campo se reconhece a partir de uma identidade comum, dada pelas questões, processos e fenômenos singulares que demarcam o campo. 
Scott e Storper (2018) buscam explicitar tal demarcação a partir da produção de conceitos que consigam apreender elementos gerais que estejam presentes nos mais diversos tipos de manifestações empíricas distintas da cidade e do urbano. Em outras palavras, os autores se propõem a produzir um conceito geral que permita demarcar um campo e, ao mesmo tempo, reconhecer a singularidade de cada cidade por meio da pesquisa. Para os autores, trata-se de se delimitar, de forma clara, o campo dos estudos urbanos. Mas o que isso significa? Coloca-se a necessidade de se "distinguir as dinâmicas da vida social que são intrinsecamente urbanas daquelas que são mais propriamente vistas como situadas fora da esfera estrita do urbano, mesmo quando são detectadas como uma questão de ocorrência empírica dentro das cidades" (SCOTT; STORPER, 2018, p. 23-24). Assim, constitui um campo de pesquisa específico denominado estudos urbanos, que é um campo específico dentro das Ciências Sociais e que pode assumir aspectos particulares dentro de cada disciplina, como na Geografia Urbana, Sociologia Urbana, Antropologia Urbana etc.

No entanto, a Geografia Histórica não satisfaz tais condições, e esse argumento pode ser desenvolvido a partir de dois pontos.

O primeiro refere-se à falta absoluta de um conjunto específico de processos e fenômenos que permita a construção de um corpo teórico e conceitual comum para se debater um conjunto mais ou menos comum de questões e problemas. Em outras palavras, o universo de questões, processos e fenômenos da Geografia Histórica é ilimitado. Não há, minimamente, um conjunto relativamente comum de questões e objetos construídos capazes de circunscrever um campo.

Por exemplo, no texto fundador da Geografia Histórica moderna, Introdução à Geografia Histórica, Carl Sauer enumera alguns temas desse suposto campo (SAUER, 2004, p.16-22): a) processos físicos que podem afetar o homem; b) homem como agente da Geografia Física; c) sítios de assentamentos humanos; d) modelos de assentamento; e) tipo de habitação; f) clímax cultural; g) receptividade cultural; h) distribuição da energia em uma área cultural; i) estados e sucessão cultural. Sem dúvida, é uma agenda de pesquisa alinhada com seu tempo e com uma perspectiva conservadora de Geografia.

William Norton (1984), em seu livro Historical analysis in geography, destacou cinco temas de interesse para a Geografia Histórica: 1) a exploração, a imigração e as fronteiras; 2) a evolução dos assentamentos rurais e urbanos; 3) a paisagem rural; 4) o transporte e as paisagens industriais e urbanas; 5) a população e as análises sociais.

No texto já citado de Pedro Vasconcelos, o autor comenta o conjunto de temas trabalhados em um livro organizado em 2003 em homenagem a Alan Baker:

No livro em homenagem ao geógrafo histórico Alan Baker, organizado por Black e Butlin (2001), dois textos teóricos são seguidos por textos com comentários às viagens de J. Locke; as representações da Palestina; aos restaurantes de Paris; a história dos teatros na Itália; aos espaços de prostituição nas cidades europeias; aos intelectuais franceses e a questão da Alsácia-Lorena; ao discurso dos camponeses na França rural; a ponte Vitória em Montreal; ao discurso colonial no Quebec; e a identidade nacional canadense (VASCONCELOS, 2012, p. 3).

Diante de tamanha diversidade temática, Pedro Vasconcelos faz o seguinte diagnóstico: "Essa dispersão temática, a meu ver, fragiliza a subdisciplina" (VASCONCELOS, 2012, p. 3, grifos nossos). Aqui, subdisciplina é sinônimo de campo. A fragilidade apontada 
por um dos principais geógrafos que constituíram a Geografia Histórica brasileira deve ser levada muito a sério. A fragilidade está na impossibilidade da constituição de um campo cujas questões centrais sejam compartilhadas pela comunidade que o sustenta. É possível que sejam compartilhadas perspectivas e formulações teóricas em comum, de caráter mais geral, assim como procedimentos metodológicos específicos e utilizados pelos pesquisadores que constituem o suposto campo. Mas isso pode ser extrapolado, de forma mais ampla, para o conjunto da chamada Geografia Humana e Geografia Física. Em outra escala, pode ser extrapolado para o conjunto das Ciências Sociais e das Ciências da Natureza. O fundamental, o alicerce, o cerne não passa por esses elementos, mas sim pelas questões concretas, pelos problemas levantados, em suma, pelo conjunto de questões, processos e fenômenos. A dispersão temática é capaz de causar a impossibilidade do diálogo em função do desinteresse pelo o que está sendo dito pelo outro. Assim, criam-se, de um lado, uma dissociação entre teoria e método e, de outro, a análise concreta do empírico. Os debates conceituais animam, mas as pesquisas concretas levam ao desinteresse. Em síntese, é necessário um conteúdo empírico concreto ao recorte temporal como ocorre na História, cujos campos possuem um conteúdo empírico associado ao tempo: História Antiga, História Medieval, História do Brasil Colonial, História da América Colonial, História da África, História Moderna, História Contemporânea etc.

O segundo ponto que nos leva a defender a impossibilidade de se pensar na Geografia Histórica como um campo é exatamente o elemento de singularização utilizado. De forma geral, qual argumento é utilizado para se definir a Geografia Histórica e marcar sua distinção em relação aos demais campos da Geografia? Em uma primeira aproximação, o traço de diferenciação seria a incorporação explícita da História na produção das pesquisas. Claude Cortez, no livro Geografía Histórica (CORTEZ, 1991, p. 12), coloca a questão da seguinte forma: a Geografia Histórica "podría definir en primera aproximación como a percepción temporal de los problemas espaciales". A "percepção" temporal nas pesquisas seria o indicador da historicidade e, portanto, o demarcador do campo. Assim, a distinção da Geografia Histórica seria a explicitação da dimensão propriamente histórica da pesquisa em Geografia. No entanto, como essa "percepção" temporal expressou, efetivamente, o caráter histórico das pesquisas? Em relação aos pioneiros da Geografia Histórica moderna (1940 a 1960), Patrício Carneiro (2016, p. 53) afirma que:

Guelke (1997, p. 224) analisou essa relação entre a geografia e a história presente nos trabalhos de Darby, Sauer e Clark. Sua conclusão é taxativa: avaliando os princípios teóricos subjacentes nas obras desses autores, pode-se afirmar que os geógrafos históricos citados não compreenderam a história como algo a mais do que o "tempo" ou o "passado". Ou seja, segundo Guelke (1997, p. 224), suas geografias históricas nada mais são do que "a descrição das alterações produzidas pelo homem na transformação de seus ambientes físicos".

O diagnóstico é duro e um pouco injusto. Se é verdade que a descrição e a narrativa eram elementos predominantes, a Geografia Histórica produzida por esses autores não poderia ser reduzida a isso. No entanto, a crítica é correta ao chamar a atenção para a deficiência com que a História foi incorporada. O que podemos apreender dessa análise é que os trabalhos dos principais geógrafos que instituíram a Geografia Histórica não aprofundaram o conteúdo dos conceitos históricos. Quando Guelke afirma que eles não compreenderam a História como algo a mais do que o "tempo" ou o "passado", ele 
quer dizer que os geógrafos se restringiram à superfície do conteúdo dessas categorias e não extraíram delas todas suas consequências teóricas, metodológicas e políticas. Mas voltaremos a essa questão depois.

A História foi reduzida ao tempo no sentido de duração (transformações e permanências) e contagem (com o passar dos anos, dos séculos), mas sem que fossem extraídas as consequências mais profundas desses elementos, que, sem dúvida, constituem a História enquanto disciplina e a História enquanto vida concreta. Seu significado tornou-se banal no sentido de expressar constatações óbvias (a paisagem muda, o tempo age sobre as feições da superfície terrestre, o contexto é importante para compreender tal lugar etc.). Tais constatações pouco contribuem de fato para a análise e funcionam mais como demarcadores cronológicos do que efetivamente históricos. O uso da categoria tempo, ainda que de forma superficial, é utilizado para explicitar a ideia de movimento, dinâmica e transformação. Sem dúvida, existe essa dimensão intrínseca ao tempo histórico, no entanto não constituiu propriamente uma novidade na Geografia, uma vez que essa ideia já estava presente nas obras de Ratzel, La Blache e Reclus, por exemplo.

O mesmo pode ser dito em relação ao passado. Quando o conteúdo dessa temporalidade não é devidamente explorado e aprofundado, ele se torna banal. Assim, não consegue participar de forma ativa da análise e se torna um demarcado cronológico, e não necessariamente histórico. É preciso compreender isto: a demarcação cronológica da pesquisa de uma paisagem ou lugar no passado não necessariamente exprime um conteúdo histórico. O conteúdo histórico só será incorporado se as categorias históricas para pensar na ação social forem explicitadas e aprofundadas. Por enquanto, podemos concluir que o "passado" foi utilizado como demarcador cronológico em oposição ao presente, no entanto sem a devida qualificação efetivamente histórica do seu conteúdo. Essa demarcação, feita com pouca substância teórica, transforma o passado em uma moldura, um quadro de referência com pouca ou nenhuma participação ativa na análise. Seria o equivalente a pensar o espaço como um palco no qual as ações se desenrolam.

Esse seria o diagnóstico geral para o período de 1940 a 1960, caracterizado pelo predomínio dos geógrafos que se dedicaram a instituir o campo da Geografia Histórica, com destaque para Carl Sauer, Henry Darby, Andrew Clark e Donald Meinig.

O que podemos dizer, de forma geral, sobre o estado da Geografia Histórica atual?

Sem dúvida, ocorreram muitos avanços no debate teórico e metodológico, principalmente em língua inglesa e francesa, em relação às categorias de tempo, temporalidade e historicidade, assim como na ampliação dos temas de pesquisa, como já apontou Pedro Vasconcelos, citado anteriormente. Esse avanço pode ser consultado, por exemplo, nas obras de Derek Gregory (1978, 1982), Lawrence Estavile (1991), David Lowenthal (1998), Maurício Abreu (1998, 2000, 2010), Pedro Vasconcelos (1999, 2002, 2009, 2012), Alan Baker (2003), entre outros. Portanto, houve um avanço quanto à crítica elaborada por Guelke, e a Geografia Histórica, certamente, não pode ser caracterizada pelo predomínio da descrição de lugares e paisagens ou da narrativa de fatos e eventos desprovida de análise. No entanto, há um elemento que não foi questionado: o uso do passado como demarcador do campo. Seja como o estudo de geografias do passado, seja como processos do passado que influenciam e constituem o presente, a Geografia Histórica ainda busca utilizar como elemento de distinção o passado.

Agora, vamos examinar criticamente essa formulação. O adjetivo que qualifica o suposto campo é "histórica". Portanto, o geógrafo deve buscar na História elementos 
que permitam, de forma densa e explícita, qualificá-la dessa forma. Tal necessidade conduz, obrigatoriamente, a uma aproximação dialógica com a História: seus conceitos, procedimentos metodológicos e campos temáticos. Aproximação dialógica não significa a conversão do geógrafo em historiador, tampouco o abandono das tradições e do corpo teórico e metodológico da Geografia, mas sim o enriquecimento mútuo, a apropriação de uma série de formulações e procedimentos próprios da História.

É exatamente esse diálogo crítico com a História que nos leva a rechaçar a ideia de definir a Geografia Histórica como um campo caracterizado pelo estudo das geografias do passado.

Em primeiro lugar, a própria História não se define como uma ciência que estuda o passado. O historiador francês Marc Bloch (2009) é enfático: a História é a ciência dos homens no tempo, cuja categoria fundamental é a de duração, que remete diretamente às ideias de temporalidade e historicidade. Portanto, o demarcador do campo disciplinar não é a temporalidade do passado, mas a dimensão temporal da ação social, o que constitui, efetivamente, o tempo histórico, o tempo dos historiadores (BARROS, 2013). O passado em si deixou de ser o elemento que sustenta o corte epistemológico da própria História. A transformação teórica e conceitual que se operou na disciplina a partir da primeira metade do século XX, com destaque para a Escola dos Annales, libertou a História da prisão de reconstruir exatamente o passado tal qual ele era e a colocou diante de problemas e questões a ser examinados a partir da temporalidade e da historicidade, ou seja, da dimensão temporal da ação social. Isso permitiu uma profunda transformação na forma de se produzir História e, ao mesmo tempo, permitiu a disciplina avançar sobre um tempo que estava proibida até então: o presente.

Não seria importante a Geografia Histórica rever seu pressuposto fundamental, aquele que é utilizado como demarcador de um campo específico? Assim, se a História não deve ser circunscrita ao passado nem se define por esse horizonte temporal, por que a Geografia Histórica deveria ficar circunscrita ou ser definida, a priori, pelo estudo do passado? Se considerarmos seriamente o adjetivo "histórico", devemos buscar seu significado mais profundo no seu campo disciplinar originário, que é a História. Isso implica o aprofundamento teórico, conceitual e metodológico das categorias históricas que são utilizadas por aqueles que produzem Geografia Histórica. As categorias de duração, permanência, temporalidade (passado, presente e futuro), longa duração, conjuntura, evento e historicidade ${ }^{4}$, por exemplo, demandam um tratamento muito mais rigoroso do que as constatações de que "a paisagem muda", "o contexto é importante", "a origem histórica dos elementos que estruturam o espaço".

Porém, antes de dar continuidade, abrimos um parêntese fundamental: aqui não queremos dizer que os geógrafos nunca realizaram esse esforço ou que nunca se deram conta dessas questões, o que seria um absurdo. No entanto, podemos constatar duas coisas: 1) não houve uma apreciação mais substancial sobre a questão da Geografia Histórica como campo;2) tais reflexões ficam restritas, majoritariamente, a um conjunto relativamente reduzido de geógrafos e são pouco perceptíveis no conjunto mais amplo da produção, seja em dissertações, teses e artigos. Pronto, fechamos o parêntese.

\footnotetext{
${ }^{4}$ Ver, por exemplo, as obras de Marc Bloch (2009), Fernando Novais (2005), Reinhart Koselleck (2006, 2012), Fernand Braudel (2009, 2013), Peter Burke (2011a, 2011b), François Dosse (2012), Jacques Le Goff (2013) e José D’Assunção Barros $(2011,2013)$.
} 
Assim como a História, a Geografia Histórica não precisa, ou melhor, não deve ser definida pelo passado, uma vez que ela também pode incorporar o presente ao seu horizonte temporal de análise. Afinal de contas, o presente também é histórico e caracterizado por diversas temporalidades que o atravessam e o constituem. Portanto, existe a possibilidade teórica de a Geografia Histórica se apropriar do presente.

Se a Geografia Histórica não deve ser definida como um campo, então qual é a nossa proposta? Compreendê-la como um método, uma forma de apreender processos e fenômenos, que pode ser empregado para qualquer campo da Geografia Social.

Em trabalho anterior (RODRIGUES, 2015), esforçamo-nos para definir a Geografia Histórica como um campo. Obviamente que agora estamos criticando nossa própria posição. No entanto, nem tudo precisa ser descartado. Naquela ocasião, sugerimos a ideia de que:

o campo da Geografia Histórica deve ser capaz de trabalhar com a relação indissociável entre tempo e espaço, temporalidade e espacialidade, onde a História, o Tempo e a Temporalidade não são meramente instrumentos auxiliares que permitem uma vaga contextualização ou moldura da análise geográfica, mas compõe, tal qual a espacialidade, o centro da análise (RODRIGUES, 2015, p. 251, grifos nossos).

Podemos ver o equívoco da formulação. O que está proposto não pode constituir um campo, mas sim um método. No entanto, há algo para se aproveitar. Se um campo não pode ser demarcado pela articulação densa entre tempo e espaço, é possível formular uma proposição metodológica a partir desses termos. A relação indissociável entre espacialidade e temporalidade implica, necessariamente, a articulação das categorias históricas no mesmo plano das categorias e conceitos da Geografia, sem hierarquização entre elas. Nessa perspectiva, o tempo histórico é compreendido como uma produção, uma fabricação social (KOSELLECK, 2012). Portanto, trata-se de um processo aberto, sempre inacabado. No entanto, como nos lembra Ruy Moreira (2019) $)^{5}$ o tempo e a história necessitam, obrigatoriamente, de uma espacialidade que permita a ação, a expressão do conteúdo social. Tal espacialidade, portanto, é igualmente produto social; logo, é produto histórico e condição para a própria história. No mesmo sentido, Carlos Walter Porto Gonçalves (2002, p. 310) afirma que:

a sociedade no seu devir histórico não é a-geográfica. A expressão, por certo, causa um certo estranhamento, embora seja natural dizer-se que o espaço que vivemos está impregnado de história. É como se fosse natural falar da historicidade do espaço geográfico e não de uma geograficidade da história. Poderíamos, à guisa de provocação epistemológica, afirmar que se a história se faz geografia é porque, de alguma forma, a geografia é uma necessidade histórica e, assim, uma condição de sua existência que, como tal, exerce uma coação que, aqui, deve ser tomada ao pé da letra, ou seja, como algo que co-age, que age com, é co-agente.

Essa proposição busca superar hierarquias e sobredeterminações entre espaço e tempo, chamando a atenção para o seu caráter imanente às relações sociais. Portanto, tomamos a espacialidade e a temporalidade como atributos constitutivos das sociedades, não exteriores, não hierárquicos e relacionais. Assim, o espaço social e o tempo histórico são produtos da ação social e, ao mesmo tempo, condições de existência e reprodução dessa própria ação.

${ }^{5}$ O belo título do livro de Ruy Moreira é a melhor síntese para compreender essa proposição: Espaço, corpo do tempo. 
Aqui é importante ressaltar as formulações de Antonio Carlos Robert de Moraes (2000, $2005,2014)$, nas quais explicita e propõe fundamentos metodológicos para a Geografia Humana. Nessas contribuições, não existe a defesa da Geografia Histórica como um campo, mas a incorporação explícita e clara da História nos fundamentos teóricos e metodológicos de constituição da própria Geografia, o que é fundamental. Moraes não está preocupado em demarcar uma campo para a Geografia Histórica, mas sim explicitar a historicidade imanente, indissociável e incontornável da Geografia Humana. É daí que extraímos parte significativa de nossa crítica à Geografia Histórica como campo e a situamos no plano do método. Assim, o que nos separa do autor é a distinção radical entre sociedade e espaço 6 .

De qualquer forma, a Geografia, nessa perspectiva, possui como objeto de análise a espacialidade das relações sociais. Tal espacialidade pode ser apreendida em qualquer período histórico. Uma vez que toda sociedade, em qualquer tempo, produz e institui uma espacialidade, ao mesmo tempo que é produzida e instituída por ela, é legítimo o interesse do geógrafo pela pesquisa em outros períodos históricos do passado, mas nada impede o mesmo tratamento metodológico para o chamado presente. Não há, portanto, justificativa teórica e empírica para limitar a Geografia Histórica ao passado. De acordo com Moraes (2000, p. 3),

Pode-se, portanto, dizer que qualquer período da história e em qualquer sociedade existe uma geografia (material e discursiva) que compõe a cultura de cada grupo social e de cada civilização. A variedade destas geografias é inerente à variedade de culturas existentes na história humana. Logo, há a necessidade de diferenciar e historicizar as culturas para bem contextualizar suas geografias.

O que significa tomar a Geografia Histórica como um método? Significa explicitar uma forma de se fazer Geografia, uma forma de apreender a espacialidade do social. Significa, portanto, explicitar uma maneira de se aproximar, construir e analisar um objeto, em que as categorias históricas estão no mesmo plano das categorias geográficas e são centrais para a análise. Assim, a História deixa de ser apenas uma contextualização ou uma bengala que apoia a análise geográfica e passa a constituir um dos alicerces da pesquisa. Em vez do famoso e enfadonho "breve histórico", das burocráticas contextualizações e recuos no tempo em que nada contribuem para o debate central, uma explicitação das categorias históricas e sua utilização para a análise.

Esta proposta de conceber a Geografia Histórica como um método fundamentado na articulação densa e não hierárquica entre as categorias e conceitos geográficos e históricos

\footnotetext{
6 "Nesse sentido, deve-se ter cautela ao definir a relação sociedade/espaço como objeto geográfico, pois tal enunciado sugere uma associação entre duas partes que se determinam reciprocamente, e que, portanto, entram com o mesmo peso na relação. E não se trata disso no caso, na medida em que o dinamismo que impulsiona o relacionamento de um grupo humano com um dado meio está totalmente localizado no âmbito do grupo, na verdade são os contatos entabulados entre seus membros que definem a forma de relacionamento de todos e de cada um com o espaço em que vivem. Assim, a relação sociedade/espaço é em si mesma entendida como uma relação social. A noção de espaço banal procura deixar bem evidente esse entendimento, ao avaliá-lo como um suporte que se qualifica pelo seu uso social e que se re-qualifica quando esse uso se altera. Aqui vai se trabalhar com a visão restrita que circunscreve apenas o que Milton Santos concebe como materialidade do espaço, a faceta que ele define como um 'sistema de objetos' (Santos, 1996), deixando o 'sistema de ações' fora da definição do espaço, como um domínio intrínseco do ser social. A nosso ver, as ações se objetivam no plano exclusivo da intencionalidade humana, sendo emanações da sociedade e dos sujeitos (individuais e coletivos) que a compõem. O espaço, nesse entendimento, é tomado como matéria que se qualifica pelo uso social a cada momento. Em suma, acata-se totalmente o seguinte juízo: 'o que faz de uma região da Terra um território de caça é o fato de uma tribo ali caçar’ (Marx, 1975)” (MORAES, 2014, p. 24).
} 
é tributária de uma perspectiva que não é nova na Geografia. Aqui nos remetemos às formulações realizadas, desde o século XIX e, principalmente, no século XX, no âmbito da Geografia, que enfatizam a necessidade do tratamento indissociável do tempo e do espaço. Tais esforços não são novos e nos legaram valiosas contribuições e reflexões que colocam a necessidade do tratamento teórico, conceitual e metodológico da dinâmica do espaço-tempo de forma indissociável. Assim, reivindicando ou não a Geografia Histórica, inúmeros geógrafos explicitaram esse fundamento teórico e metodológico e o desenvolveram dentro do escopo de suas obras, de seu tempo e seu lugar no mundo. Recentemente, Rogério Haesbaert (2021), no livro Território e descolonialidade: sobre o giro (multi)territorial/de(s) colonial na América Latina, traz um debate sobre a indissociabilidade espaço-tempo e recupera as contribuições de David Harvey, Nigel Thrift e Doreen Massey. No Brasil, para citar poucos exemplos, temos Milton Santos, em O espaço dividido e A natureza do espaço, e Ruy Moreira, em Espaço, corpo do tempo. Na Geografia Histórica brasileira, temos quase todas as obras de Maurício Abreu, Pedro Vasconcelos e Antonio Carlos Robert de Moraes. Antes de todos eles, no século XIX, não podemos nos esquecer de Élisée Reclus (1905), com sua obra-prima $O$ Homem e a Terra. Portanto, não estamos, obviamente, partindo do zero, mas, ao contrário, subindo nos ombros de gigantes.

Agora, voltando à questão do método, podemos desdobrar a questão em dois pontos: um diz respeito ao plano teórico e conceitual, e o outro, a procedimentos operacionais da pesquisa. Evidentemente que eles estão articulados, no entanto, para facilitar a apresentação, faremos uma separação arbitrária.

No primeiro, o geógrafo deve explicitar as categorias e conceitos históricos fundamentais para o trabalho de pesquisa ${ }^{7}$. No entanto, tal explicitação, ou seja, a apresentação do conteúdo, não deve ser burocrática e abstrata, mas sim articulada com o conjunto de fenômenos e processos que foram tomados como objetos de pesquisa ${ }^{8}$. De outro modo, a explicitação pode se tornar apenas um exercício de erudição, descolado dos conceitos e categorias da Geografia, o que iria reproduzir a dicotomia e dar uma falsa sensação de articulação.

O segundo ponto se refere mais diretamente aos procedimentos da pesquisa, particularmente ao processo de periodização $0^{9}$. A periodização ${ }^{10}$ pode ser definida como

7 É possível fazer uma grande lista de categorias e conceitos que podem e devem ser incorporados ao arsenal teórica da Geografia: tempo, temporalidade, historicidade, presente, passado, futuro, memória, aceleração, modernização, progresso, estrutura, conjuntura, evento, ritmo, ciclo, duração, permanência, experiência, entre outras. Sem dúvida, a Geografia já trabalha, há muito tempo, com tais categorias e conceitos, no entanto o tratamento teórico propriamente histórico pode ser aprofundado.

${ }^{8}$ Qual é a temporalidade de determinado processo ou fenômeno? De que forma diferentes temporalidades participam do processo de produção do espaço? De que forma diferentes temporalidades se articulam? Qual é o sentido da experiência concreta do tempo histórico para determinada classe ou grupo social? Qual é o tempo dominante? Quais são os tempos da resistência? Como a memória, o progresso e a modernização se constituem como elementos da análise histórica e são mobilizados politicamente? Como estrutura, conjuntura e eventos se articulam? Existe um tempo do mundo? Enfim, são inúmeras possibilidades.

9 Em relação à periodização, existem contribuições cruciais na própria Geografia brasileira, tais como as formulações de Milton Santos (1996), Miltons Santos e María Laura Silveira (2000), Pedro Vasconcelos (2002) e Maurício Abreu (2010).

10 "Especificado o lugar, há que se dar conta agora da periodização a ser utilizada no trabalho. Como todos sabemos, periodizações são segmentos de tempo que apresentam forte coalescência entre seus elementos constituintes ou, como queria Milton Santos, 'são conjuntos de relações e de proporções prevalentes ao longo de um certo pedaço do tempo'. Há, entretanto, alguns problemas com as periodizações. Em primeiro lugar, porque todas elas são arbitrárias, isto é, dependem daquilo que se quer analisar e da escala de observação utilizada. Em segundo lugar, porque raramente condizem com o tempo dos calendários, o que permite que se fale de um 'longo século XVI', como quis Braudel, ou de um 'curto século XX', como a ele se referiu Hobsbawm. Finalmente, porque elas tendem a priorizar temporalidades hegemônicas e a ação do Estado e agentes poderosos da sociedade, dando, por conseguinte, menor importância aos agentes subalternos e aos 'tempos lentos', isto é, às temporalidades não hegemônicas' (ABREU, 2010, p. 21). 
o exercício de recortar o tempo com o objetivo de identificar unidades específicas dotadas de certo grau de coerência e estabilidade, conferidas por determinados elementos que a constituem e são devidamente explicitados pelo pesquisador. Assim, a periodização é um exercício intelectual e arbitrário que produz um complexo temporal, uma unidade histórica. Periodizar significa estabelecer recortes, instituir limites, operar demarcações e rupturas no tempo: onde iniciar e parar o recorte? São os processos e fenômenos relativos à questão e ao objeto que permitem ao geógrafo operar tais ações. O trabalho será mais consistente quanto maior for a capacidade do pesquisador em estabelecer periodizações coerentes, o que significa dizer que o processo de periodização sempre deve estar acompanhado de uma justificativa clara e explícita. Nesse sentido, é crucial que os elementos constitutivos e os critérios de periodização, ou seja, aqueles que dão consistência e coerência interna ao recorte histórico, sejam explicitados e justificados. Refletindo sobre uma periodização para a história do território brasileiro, Santos e Silveira (2000, p. 23, grifo dos autores) ${ }^{11}$ afirmam que a "questão é escolher as variáveis-chave que, em cada pedaço de tempo, irão comandar o sistema de variáveis, esse sistema de eventos que denominamos período". E continuam: "períodos são pedaços de tempo definidos por características que interagem e asseguram o movimento do todo" (2000, p. 24). Os autores estão pensando na periodização sempre na tentativa de apreender a totalidade, o movimento global da sociedade. De forma mais modesta, ainda que sem desconsiderar a totalidade e, mais importante, estando sempre atento ao seu movimento, existem trabalhos e questões que podem usar critérios de periodização que não estejam diretamente preocupados com o movimento do todo, mas de certas partes, conjunturas ou eventos.

Ainda em relação à questão da periodização, não podemos deixar de mencionar a importante e robusta produção no campo da Geografia Histórica sobre tal questão, principalmente a partir da obra de Lawrence Estavile (1991). Partindo da questão da sincronia e diacronia, o autor elabora um quadro metodológico de periodização das pesquisas a partir dos cortes temporais, que podem ser, fundamentalmente, de três tipos: 1) Corte temporal transversal: é a definição de determinado período de tempo em que se prioriza a análise da sincronia, ou seja, da coexistência dos eventos e processos. Esse corte pode ser feito no passado ou pode ser um estudo do passado a partir dos vestígios encontrados no presente.

2) Corte sincrônico: refere-se ao recorte de diversos períodos históricos, tendo como objetivo principal identificar e analisar, de forma comparativa, as transformações e permanências da estrutura sócio-espacial. Nesse sentido, é possível, por meio de recortes sincrônicos específicos, analisar pontualmente a dinâmica de determinados processos.

3) Corte diacrônico: nesta perspectiva, a ênfase maior está na análise de um processo contínuo ao longo do tempo sem interrupções significativas (relativas, evidentemente, ao próprio processo ou fenômeno).

A escolha de cada tipo de periodização ou a utilização de mais de um corte dependerá, efetivamente, do tipo de pesquisa e das questões colocadas pelo pesquisador. A priori, nenhuma é pior ou melhor do que a outra, já que todas apresentam vantagens e desvantagens. Tais formulações, na Geografia Histórica, tornaram-se uma das pedras angulares da

\footnotetext{
${ }^{11}$ Nesta obra, tomando como critério de periodização o desenvolvimento e a disseminação desigual das técnicas que produzem e organizam o território usado, os autores sugerem a seguinte periodização: os meios "naturais", o meio técnico e o meio técnico-científico-informacional. Cada um desses meios constitui um período histórico específico do processo de formação do território brasileiro (p. 27).
} 
orientação metodológica, como sugerem, por exemplo, Pedro Vasconcelos (1999) e Marcelo Werner da Silva (2012).

Em função do espaço restrito deste texto, estamos caminhando para o fim. No entanto, antes de terminar, apresentaremos, ainda que de forma superficial, algumas possibilidades de uso de categorias e conceitos históricos que podem se articular com a Geografia e, dessa forma, produzir uma análise mais potente da espacialidade do social.

O primeiro exemplo é de Fernand Braudel, autor-chave para a obra de Pedro Vasconcelos. Braudel possui duas formulações que poderiam ser explicitadas e incorporadas pelos geógrafos de todos os campos específicos da Geografia Social. São elas: 1) O tempo do mundo; 2) Os tempos da história: os eventos, as conjunturas e a longa duração.

O tempo do mundo é uma expressão que aparece, rapidamente, no artigo História e Ciências Sociais: a longa duração, publicado originalmente em 1958. Neste trabalho, Braudel não desenvolve a ideia, e a expressão é utilizada para demarcar certa originalidade da História em relação às Ciências Sociais. O trecho em que a expressão aparece é o seguinte:

Cada realidade social secreta seu tempo ou suas escalas de tempo, como vulgares conchas. Mas o que nós, historiadores, ganhamos com isso? A imensa arquitetura dessa cidade ideal permanece imóvel. A história está ausente dela. O tempo do mundo, o tempo histórico aí se encontra, mas como vento em Éolo, encerrado numa pele de bode. Não é à história que os sociólogos, final e inconscientemente, querem mal, mas ao tempo da história (BRAUDEL, 2013, p. 75, grifos nossos).

A expressão torna-se ideia no prefácio do terceiro volume da grande obra Civilização material, economia e capitalismo: séculos XV-XVIII, cujo subtítulo é exatamente O tempo do mundo. Curiosamente, o autor parece esquecer que a utilizou no artigo de 1958 e atribui sua criação ao historiador Wolfram Eberhard, em um livro de 1970 chamado Conquerors and Rules. Social Forces in Medieval China. No prefácio da obra, diz Braudel (2009, p. 7, grifos do autor): "Retomando a feliz expressão de Wolfram Eberhard, intitulei-o O tempo do mundo, seguramente um belo título, se bem que promete mais do que poderei dar".

No prefácio, Braudel transforma a expressão em ideia. Para o historiador francês, é possível identificar, qualificar e experimentar um

tempo vivido nas dimensões do mundo, o tempo do mundo, que no entanto, não é não deve ser, a totalidade da história dos homens. Esse tempo excepcional rege, conforme os lugares e as épocas, certos espaços e certas realidades. Mas outras realidades, outros espaços lhe escapam e lhe são estranhos [...].

O tempo do mundo referir-se-ia portanto a uma espécie de superestrutura da história global: seria uma espécie de consumação, como que criada e suscitada pelas forças que exercem abaixo dela, embora seu peso repercuta, por sua vez, na base. Conforme os lugares e as épocas, essa dupla ação de baixo para cima e de cima para baixo foi mais ou menos importante. Mas nas regiões avançadas, econômica e socialmente falando, o tempo do mundo não urdiu tudo (BRAUDEL, 2009, p. 8, grifos do autor).

O tempo do mundo nos permite, em primeiro lugar, mapear as diferentes temporalidades que são coexistentes. Em outras palavras, a ideia de tempo do mundo nos permite apreender a espacialidade dos diferentes tempos sociais que coexistem no mesmo plano cronológico. Essa cartografia permite ressaltar as relações que se estabelecem ou não entre os diferentes espaços, suas qualidades, propriedades e intensidades. Uma vez que 
o tempo do mundo não é a soma das histórias dos homens, mas um tipo específico de temporalidade que é vivenciada nas dimensões do mundo, ela ganha qualidades analíticas e políticas fundamentais: o tempo de qual território se constitui como tempo do mundo? Como? Por quê? Quais são seus elementos estruturais?

A ideia de tempo do mundo, sem dúvida, oferece-nos a possibilidade de uma apreensão mais rigorosa, qualificada e profunda dos sentidos da história e da espacialidade, pois nos conduz à busca dos elementos estruturais que dão sentido aos processos e, dessa forma, permitem uma análise (sempre crítica) radical que apreende os fundamentos da organização social (ARANTES, 2014). Essa perspectiva contribui para aqueles geógrafos que trabalham na perspectiva da totalidade, tão cara, por exemplo, a Milton Santos (1996) e Ruy Moreira (2012), que buscam, cada um a seu modo, explicitar os fundamentos da espacialidade do social.

Além do tempo do mundo, a ideia dos tempos históricos presentes na obra de Braudel é riquíssima para a Geografia, como demonstra o trabalho de Pedro Vasconcelos (2002), que se apropriou e explicitou tal formulação em seu trabalho sobre Salvador.

Braudel identifica três tempos históricos que constituem a vida social:

1) Os eventos - acontecimentos breves, instantâneos, matéria dos cronistas e jornalistas, como um encontro, um incêndio, um discurso, uma tempestade. Os eventos são os acontecimentos sucessivos da vida individual e coletiva, em que as experiências concretas são vivenciadas. No entanto, ainda que parte de nossa história seja vivenciada neste tempo, ele possui uma limitada capacidade analítica. Braudel (2013, p. 23) compara os eventos a vagalumes, cujas "luzes pálidas reluziam, se extinguiam, brilhavam de novo, sem romper a noite com verdadeiras claridades. Assim são os acontecimentos: para além de seu clarão, a obscuridade permanece vitoriosa”. Assim, o acontecimento, sozinho, não é capaz de explicar a si mesmo e não possui os elementos necessários que nos permitam apreender a história em sua complexidade; não possibilitam a identificação e a análise dos processos e estruturas mais profundos sobre as quais eles estão assentados e que são uma condição de existência do próprio evento.

2) As conjunturas - em vez da instantaneidade do evento, as conjunturas são períodos maiores de tempo que possuem grande elasticidade, podendo durar de 4 ou 5 anos até 50 ou 100 anos (BRAUDEL, 2009, 2013). São períodos caracterizados por ciclos e movimentos periódicos. Assim como os eventos ocorrem simultaneamente uns aos outros, aos milhões, devemos falar em conjunturas que coexistem, articulam-se, atravessam-se. Esse tempo histórico é aquele que assenta os eventos e, em uma perspectiva analítica, permite ultrapassá-los, enquadrá-los e, assim, produzir uma análise mais substancial e robusta. A conjuntura, nessa perspectiva, apresenta-se como um elemento analítico fundamental, pois é, ao mesmo tempo, o assento histórico dos eventos e um movimento da própria estrutura: quanto maior a conjuntura, mais próxima da estrutura ela está e maior é a explicitação dos elementos estruturais e suas características.

3) A longa duração - é o tempo das grandes estruturas sociais que parecem imóveis, quase que fora do tempo e da própria história. Sua duração é de séculos: levam séculos para serem produzidas e outros séculos para serem destruídas. Sobre tais estruturas, Braudel (2013, p. 49, grifo do autor) afirma que:

Boa ou má, ela domina os problemas da longa duração. Por estrutura, os observadores do social entendem uma organização, uma coerência, relações bastante fixas entre 
realidades e massas sociais. Para nós, historiadores, uma estrutura é, sem dúvida, articulação, arquitetura, porém, mais ainda, uma realidade que o tempo utiliza mal e veicula mui longamente. Certas estruturas, por viverem muito tempo, tornam-se elementos estáveis de uma infinidade de gerações: atravancam a história, incomodamna, portanto, comandam-lhe o escoamento. Outras estão mais prontas a se esfarelar. Mas todas são, ao mesmo tempo, sustentáculos e obstáculos.

Braudel, sem dúvida, indica a longa duração como tempo histórico central em suas reflexões. Para ele, é neste tempo que se colocam as questões mais pertinentes de serem investigadas pela História. No entanto, isso não significa desprezar os eventos e, muito menos, as conjunturas. O que explica a centralidade da longa duração é sua preocupação com a síntese global da sociedade, portanto com a totalidade. A síntese necessita da articulação entre os três tempos históricos, mas a expressão final dessa síntese só pode ser efetivamente explicitada se for localizada na longa duração. Daí podemos reter duas lições importantes para a Geografia Histórica como um método:

1) A ideia da arquitetura dos tempos históricos (BARROS, 2013). Os diferentes tempos históricos se articulam, entrelaçam-se, perpassam uns aos outros. A tarefa fundamental é identificar o tempo histórico de cada um dos processos e fenômenos que estão delimitados em uma pesquisa e a função que desempenham dentro da totalidade ${ }^{12}$.

Quer se situe em 1558 ou no ano da graça de 1958, trata-se, para quem quer compreender o mundo, de definir uma hierarquia de forças, correntes, de movimentos particulares, depois, apreender de novo uma constelação de conjunto. A cada instante dessa pesquisa, será preciso distinguir entre movimentos longos e impulsos breves, estes, tomados desde suas fontes imediatas, aqueles, no impulso de um tempo longínquo. O mundo de 1558, tão enfadonho no momento francês, não nasceu ao umbral desse ano sem encanto. E tampouco, sempre no momento francês, nosso difícil ano de 1958. Cada "atualidade" reúne movimentos de origem, de ritmo diferentes. O tempo de hoje data, ao mesmo tempo, de ontem, de anteontem, de outrora (BRAUDEL, 2013, p. 54).

2) A ideia de espessura do tempo histórico. Tal ideia busca apreender a densidade, a profundidade com que cada elemento, processo ou fenômeno atua na constituição e reprodução social, mais do que sua duração cronológica em si. A espessura histórica diz respeito ao grau de intensidade com que algo participa ativamente do mundo aqui e agora. Quando chamamos a atenção para esse aspecto, desejamos ressaltar a atualidade de cada elemento, ou seja, a forma como ele é atual no sentido de estar presente, vivo e, portanto, atuante. $\mathrm{O}$ atual não é necessariamente novo, e esse é um mal-entendido muito comum. O atual é o que atua, age, imprime movimento, constrange, dinamiza. O que é atual pode ter surgido há séculos. Basta pensar, por exemplo, no racismo, no capitalismo ou no machismo: estruturas sociais seculares que constituem a sociedade hoje e participam ativamente de sua estruturação e reprodução; portanto, atuais e de larga espessura histórica.

A explicitação e a articulação entre o tempo do mundo e os tempos históricos abrem ricas possibilidades para a Geografia como um todo e contribuem para reforçar nossa proposição em relação à Geografia Histórica. Não há dúvidas da funcionalidade da incorporação de tais conceitos históricos à Geografia, principalmente quando podemos articulá-los com formulações que partem de elementos comuns, como as obras de Milton Santos, Ruy

\footnotetext{
${ }^{12}$ Essa lição está formulada, com outras palavras, em A natureza do espaço, de Milton Santos.
} 
Moreira ou David Harvey $(1996,2015)$. Em outras palavras, é possível a explicitação teórica da perspectiva histórica articulada com um patrimônio teórico que já existe na Geografia.

O segundo e último exemplo é de Reinhart Koselleck, historiador alemão e autor de uma vasta obra nos campos da historiografia e história dos conceitos. Koselleck possui duas categorias que devem ser trabalhadas de forma articuladas e com grande potencial para enriquecer a Geografia Histórica na perspectiva que apresentamos ao longo deste trabalho: espaço de experiência e horizonte de expectativas (KOSELLECK, 2012, p. 305-328).

Essas categorias exprimem a condição universal de existência da própria história, uma vez que esta não existe sem uma experiência prévia e que não seja motivada por alguma expectativa. Além disso, experiência e expectativa remetem, necessariamente, uma à outra, é um par indissociável, afinal não há experiência sem expectativa e não há expectativa sem experiência. Ainda, experiência e expectativa são categorias históricas que equivalem, respectivamente, a espaço e tempo.

O espaço de experiência indica um lugar concreto de vivência do tempo histórico. Segundo o autor,

A experiência é o passado atual, aquele no qual acontecimentos foram incorporados e podem ser lembrados. Na experiência se fundem tanto a elaboração racional quanto as formas inconscientes de comportamento, que não estão mais, ou que não precisam mais estar presentes no conhecimento. Além disso, na experiência de cada um, transmitida por gerações e instituições, sempre será contida e é conservada uma experiência alheia. Nesse sentido, também a história é desde sempre concebida como conhecimento de experiências alheias (KOSELLECK, 2012, p. 309-310).

O horizonte de expectativas, maior ou menor, mais próximo ou distante, refere-se ao futuro: a esperança, o desejo, o medo, a salvação, a danação etc. Sobre a expectativa,

também ela é ligada à pessoa e ao interpessoal, também a expectativa se realiza no hoje, é futuro e presente, voltado para o ainda-não, para o não-experimentado, para o que apenas pode ser previsto. Esperança e medo, desejo e vontade, a inquietude, mas também a análise racional, a visão receptiva ou a curiosidade fazem parte da expectativa e a constituem (KOSELLECK, 2012, p. 310).

Ainda que não seja possível deduzir completamente uma expectativa de determinadas experiências, elas se relacionam e constituem as condições de existência do tempo histórico. Para Koselleck, toda ação se realiza a partir da experiência adquirida e vivenciada e das expectativas dos sujeitos. A ação é produto dessas duas temporalidades, nas quais se entrelaçam passado, presente e futuro. $O$ passado é constituído por toda a experiência individual e coletiva, e o futuro é o horizonte de expectativa individual e coletiva. Assim, as duas temporalidades expressas pela experiência e pela expectativa se relacionam reciprocamente de diversas formas, o que abre um leque gigantesco de possibilidades analíticas, permitindo a incorporação substancial e efetiva da historicidade ao trabalho do geógrafo.

As categorias de Koselleck podem ser utilizadas em qualquer escala, do lugar ao global, e podem ser úteis para historicizar os processos de territorialização e produção do espaço em qualquer campo da Geografia Social. São categorias que nos permitem pensar na totalidade, porém também podem ser utilizadas em trabalhos e pesquisas que não compartilham dessa perspectiva. No entanto, não temos dúvidas de que podem ser ferramentas importantes para a análise da espacialidade social. 
O objetivo central deste texto foi elaborar uma crítica inicial à ideia de se tomar a Geografia Histórica como um campo da disciplina, como a Geografia Urbana, a Geografia Agrária etc. Para sustentar essa crítica, argumentamos que um campo não pode ser definido apenas por um horizonte temporal, nesse caso, o passado, mas necessita da delimitação de conjunto de processos e fenômenos empíricos com forte identidade entre si. Além disso, afirmamos que nem mesmo a História se define pelo estudo do passado, mas sim pelo estudo do homem no tempo, ou seja, define-se como disciplina quando se propõe a analisar a sociedade pela perspectiva temporal, o que significa produzir conceitos e categorias que explicitem a temporalidade e a historicidade dos processos. Portanto, se nem a História se define pelo estudo do passado, por que a Geografia Histórica deveria ser definida dessa forma?

Se a História se define por essa perspectiva de apreender a ação social por meio de uma de suas dimensões, a Geografia Histórica deveria ter como uma de suas preocupações centrais a explicitação de conceitos e categorias históricas no mesmo plano das categorias e conceitos geográficos para a elaboração de suas análises. O adjetivo "histórica" impõe essa necessidade e esse desafio ao geógrafo. Historicizar é mais do que indicar uma data, um corte cronológico ou fazer uma contextualização. Historicizar é explicitar a dimensão temporal e histórica de um processo ou fenômeno para além de constatações banais. É necessário, portanto, dominar e explicitar os conceitos e categorias e de que forma eles estão relacionados com os processos de produção do espaço.

A explicitação e a articulação de categorias e conceitos históricos e geográficos em um mesmo plano analítico nos permitem tecer inúmeros fios e produzir uma teia, um feixe constituído por diferentes temporalidades, ritmos, períodos, historicidades, escalas, territorialidades e espacialidades. Os feixes que constituem esse complexo tecido possuem espessuras e comprimentos diferentes, dando origem ao que se pode denominar complexo espaço-tempo. Assim, é provável que, para compreender e analisar objeto qualquer, é preciso lidar, ao mesmo tempo, com processos e elementos constitutivos que remetem à longa duração e a estruturas socioespaciais, com outros que remetem ao horizonte espaçotemporal da conjuntura e, por fim, com aqueles que remetem aos eventos. Historicidades e temporalidades distintas que possuem escalas geográficas (tanto de abrangência quanto de análise) e espacialidades distintas. Portanto, cada elemento ou processo que constitui, influencia ou condiciona nosso objeto deve explicitar sua historicidade, temporalidade, espacialidade e suas escalas de análise. Esse procedimento deixa clara a necessidade de se levar em conta o caráter multiescalar da pesquisa e da historicidade dos processos, que se articulam no tempo e no espaço.

Quando a Geografia Histórica, na sua longa tradição, incorpora de forma explícita a História, ela não constitui um campo, mas uma forma de olhar o mundo, uma forma de pensar e fazer Geografia, uma forma de construir e interrogar um objeto geográfico. É uma possibilidade de produção de conhecimento, e não um campo novo. A Geografia Histórica, nesse sentido, é um enfoque, uma perspectiva de olhar o mundo e apreendê-lo de forma sistemática. Como método, ela:

1) Coloca no mesmo plano teórico as categorias geográficas e históricas.

2) Busca produzir análises por meio da articulação indissociável entre espaço e tempo.

3) Pode ser utilizada para o estudo de qualquer processo ou fenômeno da Geografia Social. 


\section{Bibliografia}

ABREU, M. A. Sobre a memória das cidades. Território, Rio de Janeiro, v. 3, n. 4, p. 5-26, 1998.

ABREU, M. A. Construindo uma Geografia do passado: Rio de Janeiro, cidade portuária, século XVII. Geousp, São Paulo, v. 4, n. 1, p. 13-25, 2000.

ABREU, M. A. Geografia Histórica do Rio de Janeiro (1502-1700). Rio de Janeiro: Andrea Jakobson, 2010. ARANTES, P. O novo tempo do mundo. São Paulo: Boitempo, 2014.

BAKER, A. Geography and history: bridging the divide. Cambridge: Cambridge University Press, 2003. BARROS, J. D. A. Teoria da história. Petrópolis: Vozes, 2011, v. I: Princípios e conceitos fundamentais.

BARROS, J. D. A. O tempo dos historiadores. Petrópolis: Vozes, 2013.

BLOCH, M. Apologia da história ou o ofício do historiador. Rio de Janeiro: Jorge Zahar, 2009.

BRAUDEL, F. Civilização material, economia e capitalismo: séculos XV-XVIII . São Paulo: Martins Fontes, 2009, v. 3: O tempo do mundo.

BRAUDEL, F. Escritos sobre a história. São Paulo: Perspectiva, 2013.

BURKE, P. A escrita da história: novas perspectivas. São Paulo: Unesp, 2011 a.

BURKE, P. História e teoria social. São Paulo: Unesp, 2011b.

CARNEIRO, P. A. S. Origens e evolução da geografia histórica. Revista Eletrônica da Associação dos Geógrafos Brasileiros, Três Lagoas, v. 13, n. 23, p. 42-65, 2016.

CORTEZ, C. Geografia histórica. Cidade do México: Instituto Mora, 1991.

DOSSE, F. A. História. São Paulo: Unesp, 2012.

ESTAVILE, L. Organizing time in historical geography. In: GREEN, D. B. (Org.). Historical geography: a methodological portrayal. Savage, MD: Rowman \& Littlefield, 1991.

GOFF, J. L. História e memória. São Paulo: Unicamp, 2013.

GONÇALVES, C. W. P. Da geografia às geo-grafias: um mundo em busca de novas territorialidades. In: SADER, E.; CECEÑA, A. E. (Ed.). La guerra infinita: hegemonía y terror mundial. Buenos Aires: CLACSO, 2002.

GREGORY, D. The discourse of the past: phenomenology, structuralism and historical geography. Journal of Historical Geography, London, v. 4, n. 2, p. 161-173, 1978.

GREGORY, D. Action and structure in historical geography. In: BAKER, A. R. H.; BILINGE, M. (Org). Period and place: research methods in historical geography. Cambridge: Cambridge University Press, 1982.

HAESBAERT, R. Território e descolonialidade: sobre o giro (multi)territorial/de(s)colonial na América Latina. Ciudad Autónoma de Buenos Aires: CLACSO; Niterói: Programa de Pós-graduação em Geografía, 2021.

HARVEY, D. A condição pós-moderna. São Paulo: Loyola, 1996.

HARVEY, D. Paris, capital da modernidade. São Paulo, Boitempo, 2015.

KOSELLECK, R. Estratos do tempo: estudos sobre a história. Rio de Janeiro: Editora Puc Rio, 2006.

KOSELLECK, R. Futuro passado: contribuição à semântica dos tempos históricos. Rio de Janeiro: Editora Puc-Rio, 2012.

LOWENTHAL, D. Como conhecemos o passado. Revista do Programa de estudos pós-graduados em História e Departamento de História, São Paulo, n. 17, p. 63-201, 1998. Projeto História - trabalhos de memória.

MONTENEGRO, A. T. História, metodologia, memória. São Paulo: Contexto, 2010.

MORAES, A. C. R. Geografia, história e história da geografia. Terra Brasilis, Niterói, v. 2, 2000.

MORAES, A. C. R. Geografia, interdisciplinaridade e metodologia. GEOUSP (Online), São Paulo, v. 18, n. 1, pp. 9- 39, 2014.

MORAES, A. C. R. Território e história no Brasil. São Paulo: Annablume, 2005.

MOREIRA, R. A formação espacial brasileira: contribuição crítica aos fundamentos espaciais da geografia do Brasil. Rio de Janeiro: Consequência, 2012.

MOREIRA, R. Espaço, corpo do tempo. Rio de Janeiro: Consequência. 2019.

NOGUEIRA, C. E. A geografia histórica como ferramenta de análise nos estudos de história do pensamento geográfico. Terra Brasilis (Nova Série), Niterói, v. 12, 2019.

NORTON, W. Historical analysis in geography. London: Longman, 1984.

NOVAIS, F. Aproximações: estudos de História e Historiografia. São Paulo: Cosac Naify, 2005. 
RECLUS, E. El hombre y la tierra. Barcelona: Publicaciones de La Escuela Moderna, 1905, tomo 1.

RODRIGUES, G. B. Geografia histórica e ativismos sociais. Geotextos, Salvador, v. 11, n. 1, p. 241-268, 2015.

SANTOS, M. A natureza do espaço. São Paulo: Hucitec, 1996.

SANTOS, M. O espaço dividido. São Paulo: Edusp, 2008.

SANTOS, M.; SILVEIRA, M. L. Brasil: território e sociedade no início do século XXI. São Paulo: Record, 2000.

SAUER, C. Introducción a la geografía histórica. Polis, Chile, v. 3, n. 8, 2004.

SCOTT, A.; STORPER, M. A natureza das cidades: a abrangência e os limites da teoria urbana. Geografares, Vitória, n. 27, p. 5-29, 2018.

SILVA, M. W. A geografia e o estudo do passado: conceitos, periodizações e articulações espaço-temporais. Terra Brasilis (Nova Série), Niterói, v. 1, 2012.

VASCONCELOS, P. A. Os agentes modeladores das cidades brasileiras do período colonial. In: CASTRO, I.; GOMES, P.; CORREA, R. (Org.). Explorações geográficas. Rio de Janeiro: Bertrand Brasil, 1997.

VASCONCELOS, P. A. Questões metodológicas na geografia urbana histórica. In: VASCONCELOS, P. A.; MELLO e SILVA, S. B. (Org.). Novos estudos de Geografia Urbana brasileira. Salvador: Editora da Universidade Federal da Bahia, 1999.

VASCONCELOS, P. A. Salvador: transformações e permanências (1549-1999). Ilhéus: Editus, 2002.

VASCONCELOS, P. A. Questões metodológicas na geografia urbana histórica. Geotextos, Salvador, v. 5, p. 147-157, 2009.

VASCONCELOS, P. A. Geografia Histórica: campo disciplinar e questões de pesquisa. In: ENCONTRO NACIONAL DE HISTÓRIA DO PENSAMENTO GEOGRÁFICO, 3., ENCONTRO NACIONAL DE GEOGRAFIA HISTÓRICA, 1. Rio de Janeiro, 2012. Palestra.

VASCONCELOS, P. A. O universo conceitual de Milton Santos. Curitiba: CRV, 2020.

SOBRE O AUTOR

Glauco Bruce Rodrigues. Professor do Departamento de Geografia e do Programa de Pós-Graduação em Geografia da Universidade Federal Fluminense - Campos dos Goytacazes (UFF/Campos).Coordenador do Núcleo de Estudos sobre o Território e Conflitos Sociais. 


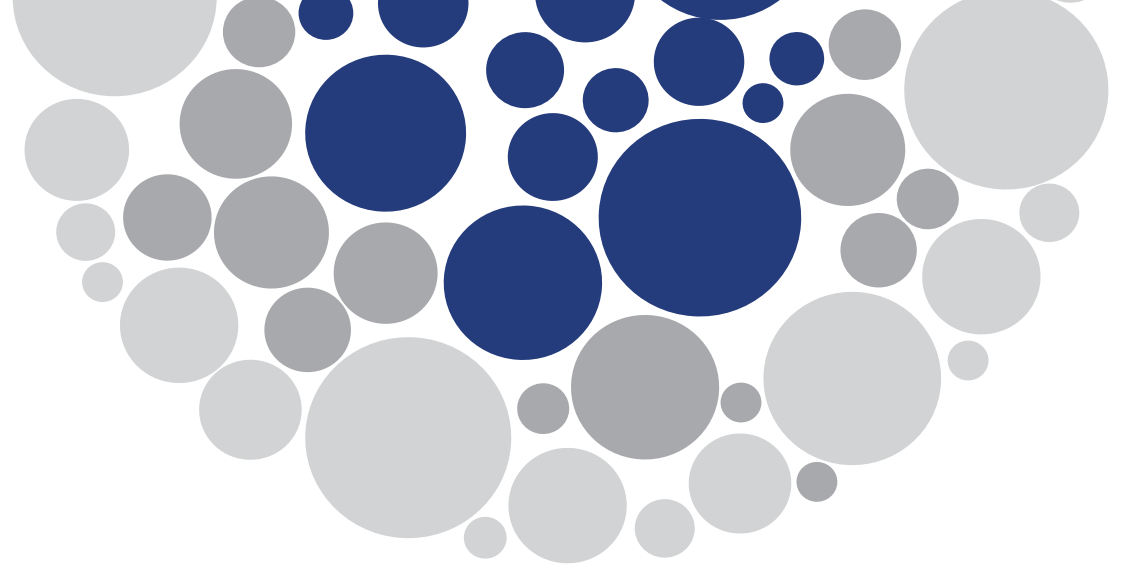

\title{
Dom Antônio Salvini (1892-1968): resgate de memória de atuação do padre italiano de Piancastagnaio (Toscana) na Baixada Campista
}

\author{
Elaine Guimarães Godinho' ${ }^{1}$, Edimilson Antônio Mota² \\ ${ }^{1}$ Mestranda no Programa de Pós-Graduação em Geografia PPG - NEPECGIM, Universidade Federal Fluminense (UFF), \\ Campos dos Goytacazes (RJ), Brasil. E-mail: elaineggodinho@gmail.com \\ 2 Prof. da Licenciatura em Geografia e do PPG UFF Campos. Coordenador do Núcleo de Ensino e Pesquisa sobre Espaço e \\ Currículo de Geografia e Imagem e Multiculturalismo - NEPECGIM. E-mail: uffmota@gmail.com
}

O presente estudo objetiva apresentar a influência da cultura italiana no espaço urbano de Campos dos Goytacazes por meio de atividades exercidas pelo imigrante italiano Silvio Salvini, originário da comuna de Piancastagnaio, na região da Toscana.

Neste trabalho, o recorte específico apresenta episódios de parte da vida e obra monástica de Dom Antônio Salvini, conhecido hoje apenas pela geração de terceira idade como Dom Antônio, evidenciando sua atuação e descrevendo curiosidades sobre o episódio da morte do monge.

O município de Campos dos Goytacazes, localizado no Norte Fluminense (mapa 1), é o maior em extensão territorial fora da Região Metropolitana do Estado do Rio de Janeiro, com $4.032 \mathrm{~km}^{2}$, e conta com uma população estimada em 507.548 pessoas, das quais cerca de 90\% estão concentradas na área urbana, e 10\%, na área rural, de acordo com o IBGE (INSTITUTO BRASILEIRO DE GEOGRAFIA E ESTATÍSTICA, 2019).

Grande parte da população hoje é formada por descendentes de africanos, os quais nos séculos passados foram escravizados - nessa mesma época, subexistiam outras colônias estrangeiras, como as de ingleses, franceses, alemães, italianos e austríacos (SOUSA, 2014, p. 142-146). A presença da cultura italiana em Campos dos Goytacazes conta com 


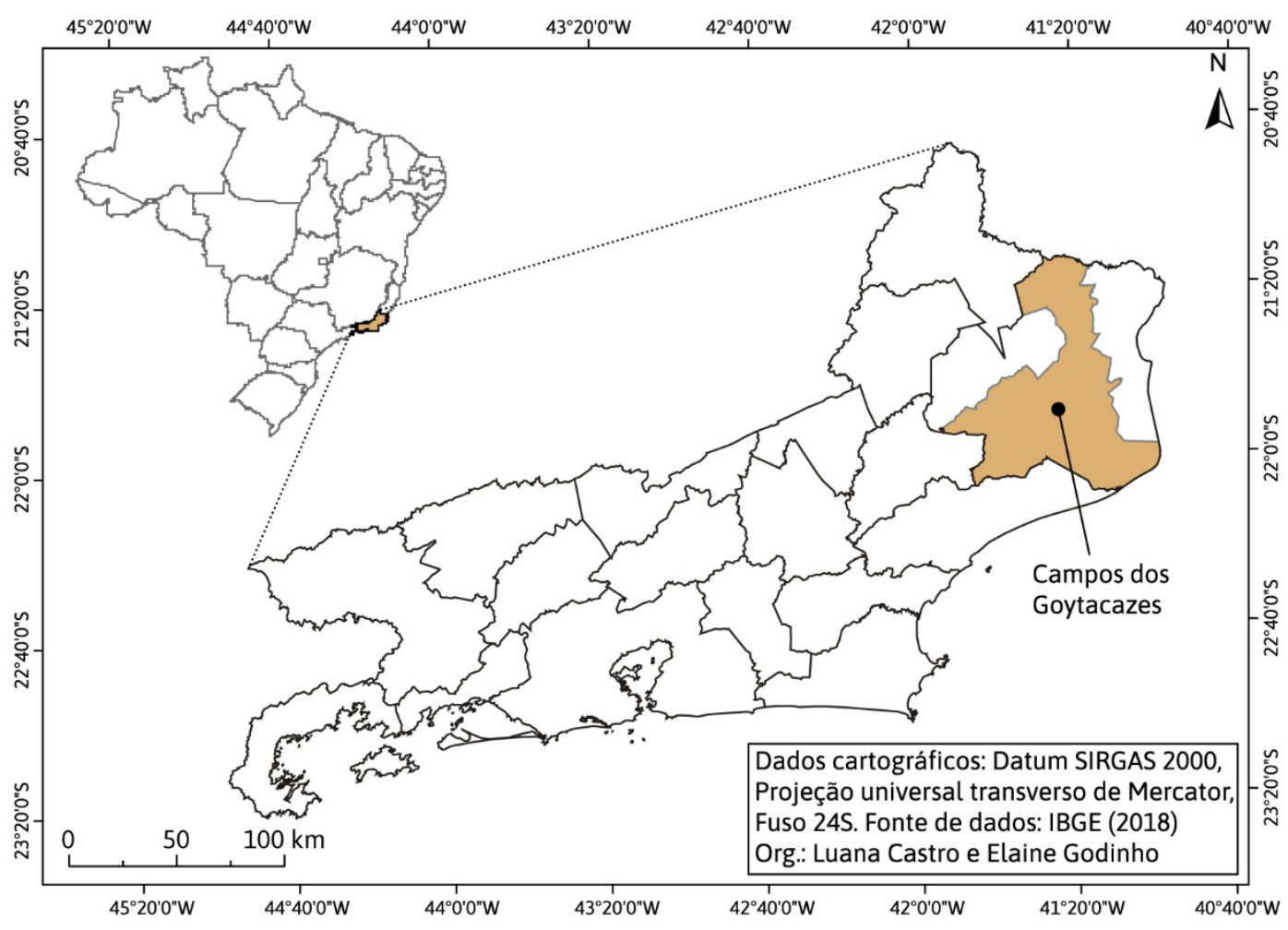

Mapa 1 - Campos dos Goytacazes (CASTRO; GODINHO, 2021a).

marcas temporais postas pelos imigrantes que vieram para a região na esperança de fazer do lugar a segunda terra fora da Itália. Neste sentido, o presente trabalho se propôs a investigar a italianidade no espaço geográfico de Campos dos Goytacazes, evidenciando o legado arquitetônico italiano por meio de prédios públicos, moradias e monumentos presentes na cidade. E, a partir deste arranjo espacial, ficaram evidentes outras atividades decorrentes desses estrangeiros e seus descendentes, como desempenhos políticos, literários, sociais e comerciais, que se desenvolveram no período da Grande Emigração Italiana para o Brasil (1861-1948).

A partir desse contexto histórico, marcas remanescentes de italianidade na paisagem levaram ao desenvolvimento desta pesquisa sobre a atuação dessa rica cultura na história da cidade, a qual precisa ser resgatada e trazida ao conhecimento dos campistas. O conceito de italianidade, por ser amplo, não é autoevidente, visto que implica termos antropológicos (aspectos que envolvem a etnicidade) e sociológicos (aspectos que envolvem construções sociais). Além disso, trata-se de um conceito externo, ou seja, de acordo com Barth (1998, p. 144), um "fenômeno particularmente visível nas situações migratórias em que autóctones têm geralmente tendência a englobar uma identificação comum, frequentemente com base num traço pejorativo (raça), os grupos recém-chegados que se percebem diferenciados". Ainda segundo esse autor, "Lopreato (1970) observa que os migrantes não deixavam a Itália como italianos, mas como genoveses, venezianos, napolitanos, sicilianos, calabreses, etc., e continuavam a identificar-se assim durante longo tempo, senão pelo resto de suas vidas" (BARTH 1998, p. 145). Portanto, a abordagem da italianidade no espaço geográfico de Campos dos Goytacazes refletirá, em termos 
gerais, aspectos múltiplos da cultura italiana para a contribuição histórica, econômica e cultural na formação da cidade.

Notas e relatos presentes no jornal Monitor Campista, no período da Grande Emigração ${ }^{1}$, permitiram evidenciar discursos que denotam o estereótipo da cultura do imigrante. Payer (1999, p. 112), ao discorrer sobre o lugar do sujeito no caso do imigrante italiano, defende que:

[...] é denso simbolicamente o processo de constituição do imigrante como sujeito nacional brasileiro, baseado, como apontamos, em um silenciamento que levou à ausência de formulações histórico-discursivas que contemplassem o real da imigração, para além dos estereótipos. Uma vez tendo havido na história a sub-partição mencionada dos valores relacionados à autoridade, à língua, ao lugar do sujeito, parece-nos que ela encontra-se ainda presente em valores incorporados na rede das filiações históricas nesse campo.

Assim, embora a influência italiana na cidade esteja presente, principalmente, na zona urbana, onde se evidencia um número maior de objetos que se relacionam com a italianidade, na área rural, como a Baixada Campista, ela também se fez presente em atividades relacionadas aos imigrantes por meio do simbólico. Sobre esse tipo de atuação, ou seja, o simbólico no espaço, Rosendahl (2018, p. 57) diz que: "As atividades religiosas imprimem no espaço transformações que estão fortemente relacionadas com os aspectos culturais da comunidade, de tal modo que o espaço pode ser percebido de acordo com os valores simbólicos ali representados".

Ao evidenciar o simbólico na presença da cultura italiana em Campos, são considerados estudos de autores que abordam a emigração italiana para o Brasil, como Emílio Franzina, e também o legado histórico, social e geográfico deixado por estudiosos que referenciam o Norte Fluminense, como Alberto Lamego. Referindo-se à cidade e à imigração estrangeira, em relação à formação étnica, na obra O homem e o Brejo, Lamego (1974, p. 118) escreveu:

A parte essencial da história de penetração da terra foi contada, com a dispersão do homem sobre a gleba. E, ademais, etnicamente esse mesmo homem já está quase feito. O índio sumiu-se no túmulo ou no sangue do colono. O negro continua a misturar-se. Mas o imigrante será sempre o português. Nenhum outro povo contribuiu sensivelmente para a atual etnia campista.

Ao registrar o trecho "Mas o imigrante será sempre o português", Lamego entende que os indígenas foram dizimados, os negros, miscigenados, e o imigrante português seria o único, de fato, a contribuir para a formação étnica do campista, enquanto outros imigrantes, como os italianos, ficariam no esquecimento, segundo seu alcance de visão regional. Sobre esse "esquecimento", Orlandi (2007) lembra que o silenciar pode ser categorizado. Segundo a autora,

[...] em muitas propostas de classificação, domina a concepção negativa do silêncio. Lyotard (1983, p. 30) propõe a distinção de quatro silêncios. Segundo ele, a frase que

\footnotetext{
${ }^{1}$ De acordo com Franzina (2015, p. 36), a emigração apresenta momentos distintos: as origens do fluxo migratório (1861-1875); a primeira fase da imigração italiana (1876-1886); o êxodo dos campos e a imigração permanente de massa nos anos da disputa colonial (1887-1901); a emigração do Sul da Itália para os Estados Unidos e a conclusão do primeiro grande ciclo migratório (1902-1927); as medidas restritivas dos anos 20 ao segundo pós-guerra (1927-1948).
} 
substitui o silêncio seria uma negativa. O que é negado por ela seria uma das quatro instâncias que constituem o universo de frases: o destinatário, o referente, o sentido, o emissor. Ainda segundo esse mesmo autor, a frase implicada pelo silêncio seria uma negativa que se formularia assim: esse caso não é da sua conta; esse caso não existe; esse caso não é significável; esse caso não é da minha conta. Essas categorizações, embora definidas negativamente, trazem alguma contribuição para a compreensão do silêncio e organizam o seu modo de significar. (ORLANDI, 2007, p. 34-35).

Além disso, ainda de acordo com a autora, "as palavras falam com outras palavras. Toda palavra é sempre parte de um discurso. E todo discurso se delineia na relação com os outros: dizeres presentes e dizeres que se alojam na memória" (ORLANDI, 2020, p. 41).

Mas não foram apenas os excertos de Lamego que se re-produziram criando campos discursivos hegemônicos para a aceitação desse enunciado como fato. Antes disso, havia forte atuação de uma aristocracia agrária e escravocrata que queria preservar esse status $q u o$, mantendo seus lucros e privilégios. Por outro lado, essa mesma classe intensificou a importância econômica de Campos, dando à cidade, no final do século XIX e início do XX, fama e modernidade no interior do estado, tendo sido uma dos municípios economicamente mais importantes do período. Entre outras inovações, Campos foi a primeira cidade a implantar luz elétrica no país. ${ }^{2}$

Ao abordar a ideia de região, Bourdieu (1972, p. 116) aponta o discurso regionalista como aquele "que tem em vista impor como legítima uma nova definição de fronteiras e dar a conhecer e fazer reconhecer a região assim delimitada", ou seja, "o ato de enunciar é proporcional à autoridade daquele que anuncia", reforçando ainda mais o reconhecimento do grupo minoritário dominante e afastando a identidade dos outros que se quis/quer longe.

Quanto a esses afastamentos, isto é, esse "silenciamento" dos imigrantes não portugueses em Campos, como os africanos e os italianos, seus elementos linguísticos, culturais e simbólicos são lugares para se conhecer e resgatar como parte da formação regional campista, e, para isso, a memória como lugar de construção e reconstrução social apresenta muitas possibilidades.

Desse modo, trazer a memória das atividades clericais de Salvini é também resgatar parte da atuação silenciada da italianidade em Campos. Assim, este texto está subdividido da seguinte forma: em um primeiro momento, é feita uma breve história acerca da origem, percurso no Brasil e formação do religioso; em um segundo momento, são apresentados o trajeto e a história ao longo de alguns episódios históricos rememorados por moradores da Baixada Campista que conviveram com o monge; por fim, são apresentadas as considerações finais.

\section{Silvio Salvini: origem e destino}

Silvio Salvini nasceu em 1892, na comuna de Piancastagnaio, uma pequena cidade medieval localizada na região da Toscana, ao sul de Siena (mapa 2).

De acordo com informações históricas da Associazione Turistica ProLoco di Piancastagnaio, os manuscritos de Giovanni Antonio Pecci (1693-1768), da segunda metade do século XVII, descrevem a geografia local como situada: "[...] na costa oriental do Monte Amiata, na encosta onde termina uma pequena planície, que se desprende

\footnotetext{
2 A Sultana do Paraíba (ALVES, 2009).
} 


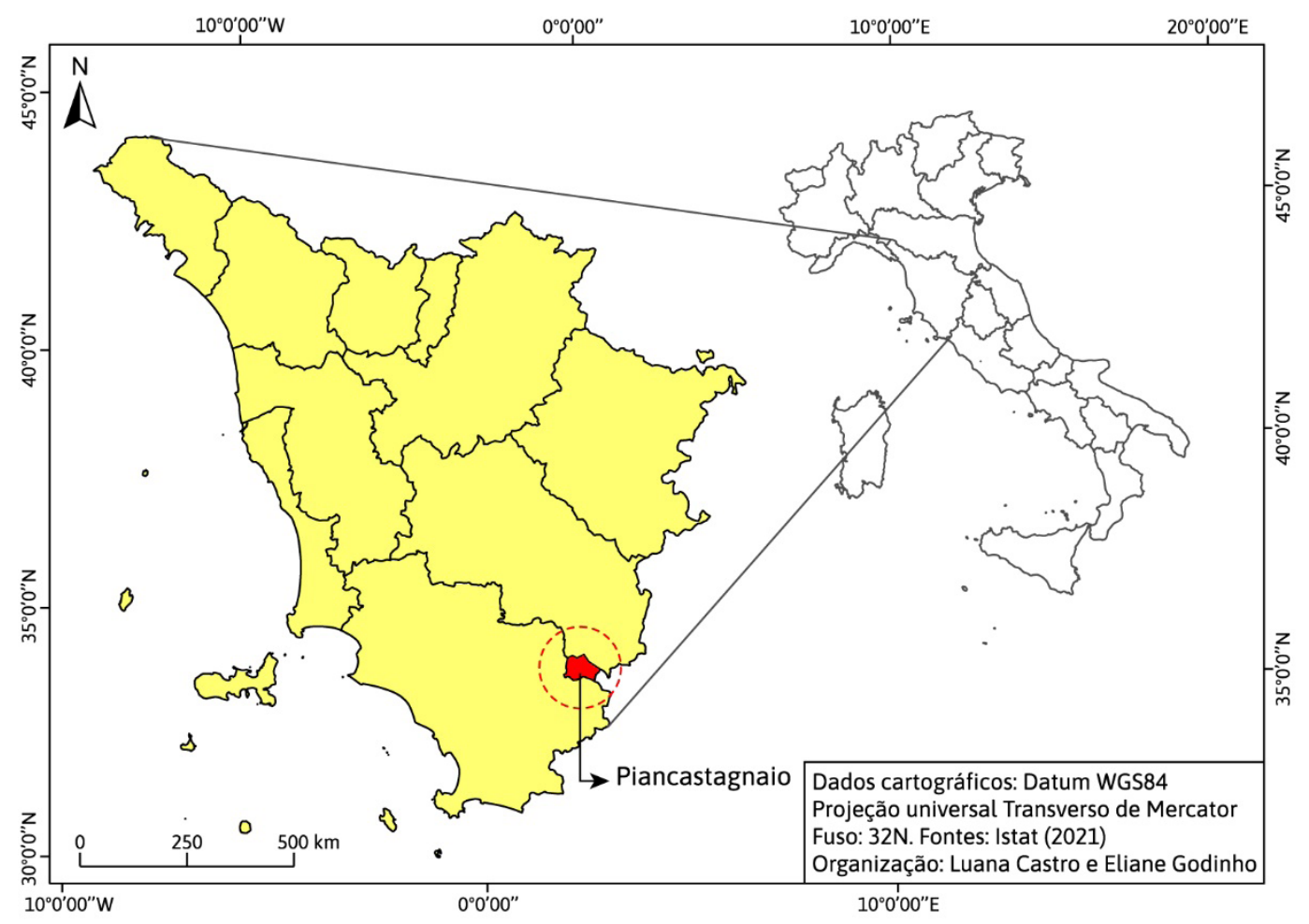

Mapa 2 - Toscana: comuna de Piancastagnaio em destaque circular (CASTRO; GODINHO, 2021b).

da última curva da montanha e através da qual sobe um topo da mesma, um planalto cultivado por belos castanheiros, cujas sombras são agradáveis para passeios no verão" (tradução nossa). ${ }^{3}$

Não foram encontrados registros escolares digitalizados de Salvini nos dados disponíveis consultados da Hemeroteca de Piancastagnaio, por isso ainda pouco se sabe sobre a história de sua infância na comuna e seus registros civis, mas, de acordo com a documentação cedida pelo Mosteiro de São Bento, no Rio de Janeiro, Silvio Salvini era o verdadeiro nome de "Dom Antônio" - como era conhecido pela Baixada Campista.

Sua formação clerical se deu no Rio de Janeiro em 1922, como é possível atestar na Figura 1.

Como é possível perceber na Figura 1, a trajetória curricular de Dom Antônio Salvini comprova sua excelência no curso de Teologia, do Mosteiro de São Bento, Rio de Janeiro, sendo aferida como "magna cum laude".

Depois, ele atuou oficialmente como superior da Casa da Tijuca, no Rio de Janeiro, de 1939 a 1964, e como superior da Casa da Fazenda de São Bento, de Campos, até 1968, quando morreu. Porém, a partir dos anos de 1940, são encontrados registros de suas atuações nos livros paroquiais de Baixa Grande em batismos e matrimônios pela região de Mussurepe. Além disso, depoentes afirmam que o monge chegou à Baixada Campista na década de 1940 .

3 "E' situata la terra di Piano-Castagnaio nella costa orientale del Monte Amiata, sul declive appunto, o scesa, ove termina una piccola pianura, che si stacca dall'ultimo giro di detto Monte, e per il quale alla cima del medesimo si ascende, pianoro coltivato con bellissimi castagni, lombra dei quali, nel calore estivo, serve a un grato e delizioso passeggio." (PROLOCO PIANCASTAGNAIO, 2020). 


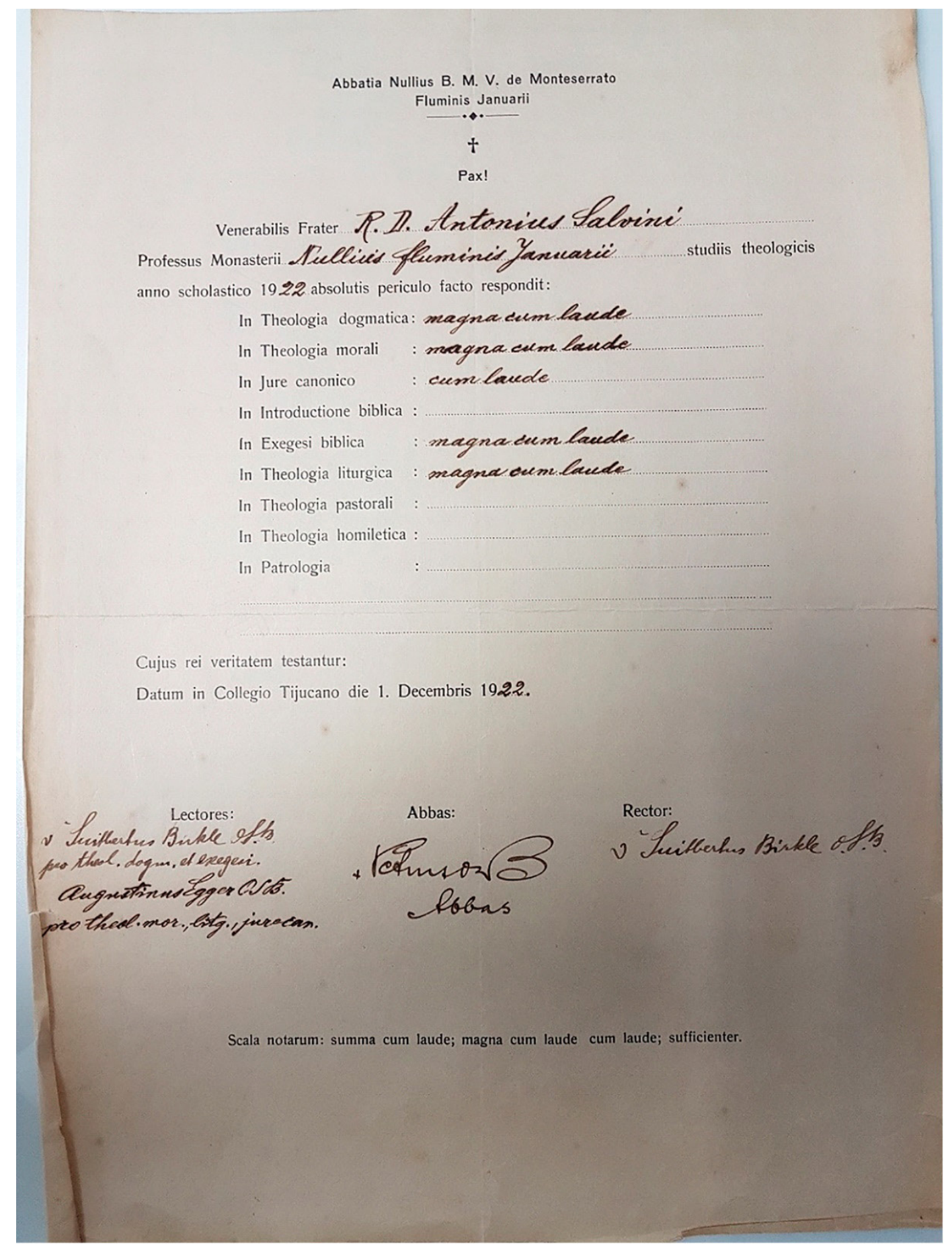

Figura 1 - Histórico de formação acadêmica de Dom Antônio Salvini.

Fonte: Mosteiro de São Bento, Rio de Janeiro. Acesso: 11 set. 2020.

\section{Silvio Salvini: atuação na Baixada Campista}

Ao examinar os livros de registro de sacramentos da Ordem Beneditina de Campos, do período de 1938 a 1950, que correspondem aos números de 1 a 4, disponibilizados pela Arquidiocese de Baixa Grande, a atuação de Dom Antônio Salvini se deu a partir de 1940 em toda a região administrada pela Ordem, realizando batismos e matrimônios. 
Como professor, ele percorria toda a região, atendendo a 32 escolas das comunidades locais, não apenas na Baixada Campista, mas também em algumas localidades de São João da Barra (SJB), sempre se deslocando de bicicleta e a cavalo.

Segundo as informações de Gerson Amaro Ribeiro, 77 anos, ex-aluno do monge, nascido em Cazumbá, e que realiza serviços ao Mosteiro desde jovem, são diversos os locais onde o sacerdote prestava assistência, conforme o Quadro 1.

De acordo com o Quadro 1, a abrangência do trajeto demonstra o quantitativo expressivo de comunidades assistidas pelo sacerdote no ensino da catequese, na celebração de missas e na prestação de assistência social.

Em relato cedido por Gerson, Dom Antônio Salvini foi um padre muito humilde, atencioso, exímio em trabalhos sociais, admirado por todos os fiéis e prestador de muitos serviços à comunidade. Como já mencionado, percorria toda a Baixada Campista de

Quadro 1 - Localidades de atuação sacerdotal de Dom Antônio Salvini.

\begin{tabular}{|c|c|c|c|}
\hline Cidade & $\begin{array}{l}\text { Localidade } \\
\text { (Distrito) }\end{array}$ & Instituição & Endereço/localização \\
\hline Campos & Mussurepe & Mosteiro de São Bento & Estrada Rural, Baixa Grande \\
\hline Campos & Mussurepe & Capela da Pitangueira & Baixa Grande \\
\hline Campos & Mussurepe & Igreja São José (Capela) & Córrego Fundo \\
\hline Campos & Mussurepe & Igreja Nossa Senhora Aparecida & Azeitona \\
\hline Campos & Mussurepe & Colégio de São Bento & Baixa Grande \\
\hline Campos & Mussurepe & Capela & Marrecas \\
\hline Campos & Mussurepe & Igreja de Santo Amaro & Xexé \\
\hline Campos & Sto. Amaro & Capela & Boa Vista \\
\hline Campos & Sto. Amaro & Capela & Caboio \\
\hline Campos & Sto. Amaro & Capela & Correnteza \\
\hline Campos & Sto. Amaro & Capela & Canto do Engenho \\
\hline Campos & Sto. Amaro & Santuário de São Martins & São Martins \\
\hline Campos & Sto. Amaro & Capela de Santo Amaro & Tocos \\
\hline Campos & Farol & Igreja N. S das Rosas & Av. Olavo Saldanha, s/n \\
\hline Campos & Farol & Capela & Vila do Sol \\
\hline SJB & Barra de Jacaré & Capela & Barra de Jacaré \\
\hline SJB & Açú & Capela de São Pedro & Açú \\
\hline SJB & Grussaí & Igreja de Sto. Amaro & Av. Liberdade, 987 \\
\hline SJB & Quixabá & Igreja de São Pedro & Chatuba \\
\hline SJB & Campo de Areia & Capela & Campo de Areia \\
\hline SJB & Águas Pretas & Colégio Coelho da Silva & Águas Pretas \\
\hline SJB & Sabonete & Igreja N.S. Conceição & Sabonete \\
\hline SJB & Farol & Igreja N.S. Navegantes & Farol \\
\hline SJB & Farol & Igreja N.S. Perpétuo Socorro & Boa Vista \\
\hline SJB & Farol & Igreja São Tomé do Farol & Farol \\
\hline Campos & São Sebastião & $\begin{array}{l}\text { Igreja Matriz de São Sebastião (ia apenas } \\
\text { quando convidado) }\end{array}$ & São Sebastião \\
\hline
\end{tabular}


bicicleta ou a cavalo. "A bicicleta era italiana, ele trouxe da terra dele; mais tarde ele teve uma lambreta, uma motinha, e só depois, nos anos 60, é que o abade comprou um fusca vermelho, que de vez em quando ele usava. Mas o carro era da Ordem", disse Gerson.

A assistência a lugares remotos da Baixada Campista reflete a importância da aptidão vocacional de Salvini para tratar esses espaços territoriais, visto que sua presença marca o poder da Ordem que estava sob o seu controle. Mas essa relação se dá em uma estrutura nem sempre polivocal, uma vez que seu papel vocacional humanista está intimamente relacionado ao papel político da Igreja Católica de atuação nesses espaços; portanto, envolve aspectos como religião, território e territorialidade. Ao abordar o conceito de espaço e religião, Rosendahl (2002, p. 59) diz sobre essa tríade:

Os espaços apropriados efetiva ou afetivamente são denominados territórios. Territorialidade, por sua vez, significa o conjunto de práticas desenvolvido por instituições ou grupos, no sentido de controlar um dado território. É nesta poderosa estratégia geográfica de controle de pessoas e coisas, ampliando muitas vezes o controle sobre espaços, que a religião se estrutura, enquanto instituição, criando territórios seus.

Como bem coloca a autora, a apropriação do território tem a ver com o conjunto de práticas cujo sentido é controlar pessoas e coisas. O entrevistado Chichico (2020) não tece críticas a respeito da memória de Dom Salvini: "Ninguém tinha nada para falar desse padre. Era muito bondoso, ajudava muito as pessoas, toda vida ele foi assim. Ninguém nunca falou nada dele, teve uma vida exemplar, era muito humilde, parava e conversava muito com as pessoas, conhecia todo mundo". De fato, essa é a verdade de Chichico. A memória não o traiu a respeito do monge, e sua admiração é fruto da convivência diária com Dom Antônio Salvini. Porém, ao analisar as atividades laborais do monge apenas como parte do cumprimento da sua função na Ordem religiosa, não estaria Dom Salvini apenas exercendo com eficiência o papel de catequizador, e, para isso, utilizava-se dos instrumentos de controle ao seu alcance para manter as 32 comunidades assistidas sob o seu domínio?

Como foi exposto anteriormente, território significa poder, e este pode estar expresso em formas simbólicas, o que Corrêa (2018) denominou "formas simbólicas espaciais", por estarem diretamente relacionadas ao espaço, constituindo-se em seus fixos e fluxos. Assim,

A relação íntima entre certas formas simbólicas e espaço resulta de uma política locacional das formas simbólicas, derivadas, por sua vez, da intenção delas de cumprirem o mais eficientemente possível o papel delas esperado por aqueles que as conceberam e as produziram. (CORRÊA, 2018, p. 228).

Considerando o Mosteiro de São Bento, em Mussurepe, em Campos dos Goytacazes, como forma simbólica de poder, primeiramente se fixou naquela paisagem rural o prédio da Ordem para desenvolver sua política locacional. Posto isto, seria função cotidiana dos monges usar mecanismos discursivos (doutrina) na assistência aos fiéis e manter o domínio da política local com o uso da fé.

Essa política envolve as dimensões absoluta, relativa e relacional do espaço. Uma forma simbólica espacial tem uma localização absoluta, um sítio, onde ocorreu um evento considerado significativo, ou que é considerado adequado ou eficaz para celebração, contestação ou memorialização, ou ainda porque o local já é dotado de algum atributo simbólico que valorizaria os objetos simbólicos fixos e as paradas, desfiles ou procissões, ampliando a força simbólica deles. (CORRÊA, 2018, p. 228). 
Nesse caso, Dom Salvini, na memória do entrevistado Gerson, torna-se uma pessoa sem contradições e passa a ocupar o lugar do sagrado. Para ele, o trabalho do monge é isento de críticas, como relata:

Dom Antônio foi professor de catecismo a vida toda e fez um trabalho muito bom. Ele percorria 32 escolas na região ensinando religião. Não temia nada, entrava na lama, andava nos alagadiços a cavalo carregando água benta, fazia de tudo pra servir as pessoas. Ele fazia extrema-unção..., quando chamavam ele em qualquer lugar que fosse. Era muito atencioso, por exemplo, se alguém precisasse de uma roupinha, qualquer coisa assim, gente muito pobre né, sem condições, ele dava um jeito de levar pra pessoa. Ele ia até o Açú de bicicleta. Ele percorria Águas Pretas, Sabonete, Córrego Fundo, Marrecas, Barra de Jacaré, toda essa região, e dava aula no Colégio de São Bento e no Grupo de Mussurepe. Servia nas capelas de Boa Vista, Mussurepe, Águas Pretas, Azeitona, São Pedro, São Martins, Canto do Engenho e ajudava na administração do Mosteiro. No dia da morte dele, ele tava indo de bicicleta para o Farol e parece que chamaram ele, coisa assim, ele foi olhar pra trás e nisso que ele virou parece que o carro pegou ele.

De acordo com Corrêa (2018, p. 41), "a memória é seletiva e influenciada por aqueles que observam a paisagem”, pois “a memória tem uma dimensão polivocal”. Assim, acerca da polivocalidade, cada convívio prezará por uma memória particular, e a população de convívio fará também uso da coletiva. Um exemplo de coletividade, neste caso, pode ser citado no episódio da morte do padre. Ainda segundo o relato de Gerson, nessa época a população se reuniu e fez uma carta ao abade superior para que o corpo de Dom Salvini fosse enterrado em Mussurepe, visto que é costume da Ordem conduzir os corpos dos sacerdotes para serem sepultados no cemitério do Mosteiro, no Rio de Janeiro. $\mathrm{O}$ abade concordou com o desejo da comunidade, então o padre Antônio Salvini teve seu sepultamento no cemitério do Mosteiro de São Bento, em Mussurepe.

Atualmente, os restos mortais dele foram exumados por conta da restauração pela qual o mosteiro está passando e estão guardados à espera do término das obras, para que sejam sepultados de acordo com os costumes beneditinos: no altar da igreja.

De acordo com outro depoimento de um morador da região, Francisco de Assis Pessanha da Silva, 75 anos, servidor público aposentado da prefeitura, conhecido em Mussurepe como Seu Chichico:

[...] todo mundo chamava ele de Dom Antônio, ele era português né, tinha um sotaque carregado, mas falava muito bem o português. Ele foi o padre que fez meu casamento. Esse padre andava ou a cavalo ou de bicicleta pela região toda da Baixada, a vida todinha dele foi isso aí, desde que chegou aqui na região. Não tinha tempo ruim pra ele não. Sempre que requisitavam ele, pra qualquer coisa, ele ia, de qualquer jeito. Tinha muita paciência, tava sempre ajudando as pessoas. Muito amoroso. Não era muito alto não, era da minha estatura mais ou menos, não era gordo não, era esbelto... parece até que eu tô vendo ele aqui na frente, lembro muito dele. Ele foi atropelado entre a casa de um irmão meu, Celso Rodrigues da Silva, e a casa de Marcelino, que ficava do outro lado. Quando ele morreu já tinha idade, ele já morreu na idade de velho já. Olha, quando eu casei, eu tinha 20 anos, e ele já devia ter uns 60, eu acho. Nessa época o padre usava um relógio de bolso, daqueles que tinha uma corrente, sabe como é? Ele guardava no bolso. Ele tinha um carinho com aquele relógio... No dia que ele morreu, o relógio sumiu. Eu acho que eu sei quem roubou o relógio... vou falar procê... Era um homem que eu até trabalhei pra ele quando era jovem. Essa pessoa não tá aqui mais entre nós. Todo mundo dizia que quem roubou o relógio foi o Francisco Sardinha, 
mas a polícia na época não achou nada, então não se pode falar nada, né? Mas todo mundo fala isso. Hoje eu falo porque ele já morreu, né. Ele era puxador de cana e tinha um tratorzinho. Ele tinha umas terrinhas ali na estrada do Jenipapo, mas ninguém nunca pode provar nada, porque ninguém viu, isso é que o povo fala, né? Porque o corpo do padre ficou caído na estrada umas três horas até buscarem ele... Mas todo mundo adorava Dom Antônio. Esse foi um padre que chegou e todo mundo gostou dele. Era de uma linha tão fina, que nunca ninguém abriu a boca pra falar nada dele, porque de outros sempre falavam uma coisinha, né, mas dele não, só falavam bem, até hoje falam bem dele.

Ainda sobre a morte de Dom Antônio, Gerson Ribeiro, o primeiro entrevistado, confirmou o relato de Francisco. Ambos afirmaram o local da morte, o episódio do atropelamento, cujo veículo até hoje não se sabe se fora identificado, o desequilíbrio da bicicleta e o fato de duas pessoas, entre as quais o agricultor Francisco Sardinha, terem sido os únicos responsáveis por guardar o corpo até a chegada do socorro, que na época demorou cerca de três horas para recolhê-lo.

Acerca do resgate da memória do episódio da morte, sabe-se que as memórias também podem ser inventadas. Sobre a invenção da memória, Corrêa (2018, p. 41) diz que:

A memória, por outro lado, pode ser inventada, e para isso a paisagem desempenha um papel-chave, exibindo cenas que transmitem mensagens sobre um passado que as elites desejam que seja recriado, inventado. As formas simbólicas espaciais constituem o veículo para esta transmissão. Trata-se da paisagem da simulação do passado, que transporta o observador a um passado que não existiu, criando uma memória seletiva e equivocada.

Nos depoimentos colhidos do senhor Gerson e do senhor Chichico, ambos expressam a verdade a respeito da memória do padre Dom Antônio Salvini. Como coloca Corrêa no trecho anterior, a memória pode ser inventada, visto que ela é fruto da imaginação, e, nesse caso, a paisagem rural, o prédio da Ordem e as atividades assistenciais e catequéticas do monge são elementos robustos na criação de uma memória seletiva, equivocada ou não. Assim, a memória do Dom Antônio Salvini não é uma criação equivocada. Além dos depoimentos orais dos entrevistados, a trajetória do monge está documentada desde sua saída da Itália, sua formação e atuação no Mosteiro de São Bento até suas atividades assistenciais no Mosteiro em Mussurepe, na Baixada Campista. Posto isto, foram vistas as possibilidades de, a partir de sua memória, reconstruir a paisagem, o tempo e o espaço da atuação sacerdotal de Silvio Salvini, a começar pela pergunta sobre o porquê da escolha do "heterônimo" "Dom Antônio", ressoando aportuguesamento e se sobrepondo à italianidade no "ortônimo" de "Dom Salvini", mas isso é questão para um outro trabalho.

\section{Conclusão}

Com base em pesquisa nos livros paroquiais disponibilizados pela Arquidiocese em Baixa Grande (Campos dos Goytacazes), em documentação digitalizada cedida pelo Mosteiro de São Bento e em dois relatos acerca do protagonismo do padre Antônio Salvini na Baixada Campista entre os anos de 1940 a 1968, este texto discorreu sobre a atuação e morte do monge italiano a fim de trazer um breve recorte do tempo-espaço da atuação e assistência a 32 comunidades feitas pelo o então Dom Salvini. Abordou a 
importância das formas simbólicas espaciais, um conceito proposto pelo geógrafo Roberto Lobato Corrêa para tratar a ideia de sítio como lugar de acontecimento e de memória polivocal. Para a estratégia geográfica de controle de pessoas e coisas para a ampliação do controle sobre espaços pela religião enquanto instituição, os espaços apropriados efetiva ou afetivamente (territórios) e as práticas desenvolvidas por instituições ou grupos (territorialidade), utilizou-se de conceitos de Zeny Rosendahl. Por fim, o resgate da memória de atuação do padre italiano de Piancastagnaio (Toscana) na Baixada Campista representa a possibilidade de reconstruir, a partir de sua memória e com base nas suas atividades, não somente surajetória, mas também o papel político e social da Ordem do Mosteiro de São Bento na paisagem campista.

\section{Referências}

ALVES, H. M. A Sultana do Paraíba. Reformas urbanas e poder político em Campos dos Goytacazes 1890-1930. Rio de Janeiro: Arquivo Público do Estado do Rio de Janeiro, 2009.

BARTH, F. Grupos étnicos e suas fronteiras. In: POUTIGNAT, P.; STREIFFFENART, J. Teorias da etnicidade. São Paulo, SP: UNESP, 1998.

BOURDIEU, P. O poder simbólico. Rio de Janeiro: Bertrand Brasil, 2007.

CASTRO, L.; GODINHO, E. Mapa de Campos dos Goytacazes. Petrópolis, 2021a. Acervo Pessoal.

CASTRO, L.; GODINHO, E. Mapa da Toscana: comuna de Piancastagnaio. Petrópolis, 2021b. Acervo Pessoal. CORRÊA, R. L. Caminhos paralelos e entrecruzados. São Paulo: EDUSP, 2018.

FRANZINA, E. A grande emigração: o êxodo dos italianos do Vêneto para o Brasil. 2. ed. Campinas: Ed. UNICAMP, 2015.

INSTITUTO BRASILEIRO DE GEOGRAFIA E ESTATÍSTICA - IBGE. Censo populacional 2019. Rio de Janeiro, 2019. Disponível em: <https://www.ibge.gov.br/estatisticas/sociais/populacao/9103-estimativasde-populacao.html? edicao=25272\&t=resultados $>$. Acesso em: 14 jul. 2021.

LAMEGO, A. R. O homem e o brejo. 2. ed. Rio de Janeiro: Lidador, 1974.

ORLANDI, E. P. Análise de discurso. 13a . ed. Campinas: Editora Pontes, 2020.

ORLANDI, E. P. As formas do silêncio no movimento dos sentidos. 6. ed. Campinas: Editora da UNICAMP, 2007.

PAYER, M. O. Memória da Língua. Imigração e Nacionalidade. 1999. 186 f. Tese (Doutorado em Língüística)Universidade Estadual de Campinas, Campinas, 1999. Disponível em: < http://repositorio.unicamp.br/ jspui/bitstream/REPOSIP/270700/1/Payer_MariaOnice_D.pdf>. Acesso em: 19 Ago. 2020.

PROLOCO PIANCASTAGNAIO. La Storia. 2020. Disponível em: <https://www.prolocopiancastagnaio. it/la-storia/>. Acesso em: 11 set. 2020.

ROSENDAHL, Z. Espaço e religião: uma abordagem geográfica. 2. ed. Rio de Janeiro: EDUERJ, 2002.

ROSENDAHL, Z. Uma procissão na Geografia. Rio de Janeiro: EDUERJ, 2018.

SOUSA, H. Cyclo Aureo: História do $1^{\circ}$ Centenário de Campos. Campos dos Goytacazes, RJ: Essentia, 2014. Reedição da obra original de 1935.

\section{SOBRE OS AUTORES}

Elaine Guimarães Godinho. Mestranda no Programa de Pós-Graduação em Geografia PPG - NEPECGIM, Universidade Federal Fluminense (UFF), Campos dos Goytacazes (RJ), Brasil.

Edimilson Antônio Mota. Prof. da Licenciatura em Geografia e do PPG UFF Campos. Coordenador do Núcleo de Ensino e Pesquisa sobre Espaço e Currículo de Geografia e Imagem e Multiculturalismo - NEPECGIM 


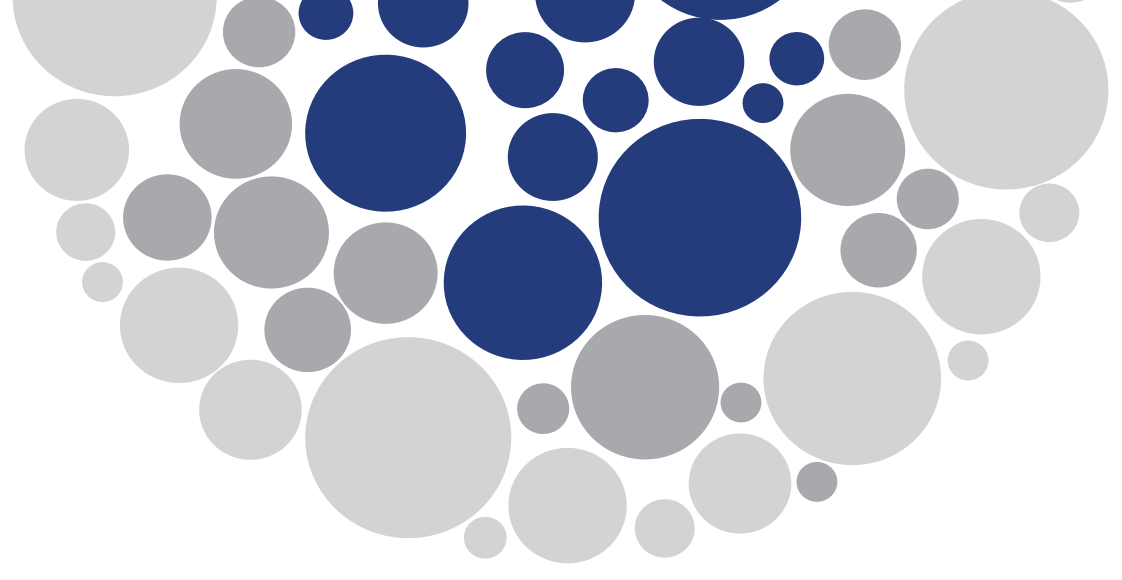

\title{
Processos socioespaciais e imigrações: italianos, galegos e outros grupos nos séculos XIX e XX em Salvador, Bahia
}

\author{
Daniel de Albuquerque Ribeiro ${ }^{a}$ \\ a Bolsista PNPD/CAPES no programa de Pós Graduação em Geografia da UFF/Campos da Universidade Federal Fluminense. \\ E-mail:danalbrib@gmail.com
}

\section{INTRODUÇÃO}

Os estudos brasileiros sobre as imigrações ocorridas no final do século XIX e início do $\mathrm{XX}$ costumam ter um maior enfoque nos fluxos que se dirigiram às regiões Sudeste e Sul. É compreensível que, em muitos casos, por voltarem sua atenção para essas regiões, os pesquisadores de determinado grupo desconheçam a existência de fluxos imigratórios anteriores que se dirigiram a outras regiões e estados do país. Visando contribuir com a ampliação do debate a respeito da imigração no Brasil, este texto apontará estudos realizados sobre dois grupos europeus que formaram colônias em Salvador, Bahia.

Existem registros de colônias italianas na capital baiana desde o período colonial, e, no contexto da substituição de mão de obra escrava, foram trazidos imigrantes italianos para a Bahia em 1840, antecedendo, assim, os registros que apontam os fluxos para São Paulo como sendo os primeiros do Brasil.

O segundo grupo trabalhado neste texto, o dos galegos, formou em Salvador a maior colônia espanhola do país já no século XX, chegando ao número de 50 mil imigrantes na cidade. A força da colônia galega foi expressiva, a ponto de fundar um time de futebol (Galícia Esporte Clube), que ganhou títulos estaduais e cuja torcida rivalizava com a dos outros dois principais times do estado (Esporte Clube Bahia e Esporte Clube Vitória).

Outros grupos também estabeleceram colônias na capital baiana, a exemplo dos portugueses, alemães e ingleses. Além desses, um grupo com grande expressividade foi 
o dos sírio-libaneses, cujos descendentes podem ser encontrados com certa facilidade no centro original soteropolitano e sua primeira periferia. A citação desses grupos serve para pontuar a diversificação dos fluxos imigratórios ocorridos entre os séculos XIX e XX, contudo, neste texto, o enfoque será dado aos italianos e galegos, o que não impede a referência às imigrações euroasiáticas em Salvador quando necessário.

Este estudo é fundamentado em um levantamento de dados populacionais realizados em uma área da cidade de Salvador intitulada Eixo Pelourinho-Santo Antônio (EPS) (Figura 1). O EPS é uma conceituação desenvolvida por Ribeiro (2018) para explicar a relação entre alguns bairros da cidade de Salvador situados no centro original e parte da primeira periferia da cidade. Nesse se observam as conexões do próprio EPS com as diferentes escalas, locais, regionais, nacionais e mundiais.

O levantamento dos dados populacionais ocorreu em três diferentes momentos da pesquisa, sendo que os dois primeiros de caráter quantitativo foram realizados em 2007 e 2011, enquanto o terceiro de caráter qualitativo se efetuou entre 2014 e 2018. Durante esse período, houve o processo de amadurecimento da pesquisa, e, com isso, ocorreram ajustes metodológicos, ao mesmo tempo que, paralelamente às análises dos dados, outras formas de estudo se efetivaram, entre as quais se destacam a observação em campo e o aprofundamento histórico por meio da revisão bibliográfica. A combinação desses elementos permitiu ampliar a compreensão das informações obtidas nas entrevistas e, assim, chegar aos resultados debatidos neste texto.

Em 2007 e 2011, o objetivo do levantamento era compreender o perfil da população para um estudo sobre gentrificação, no entanto, além da constatação da existência do processo, ocorreram outras descobertas. Das edificações pesquisadas, $1.175^{1}$ foram identificadas como sendo habitadas, então se realizou entrevista em 344 unidades habitacionais, das quais se constatou que $272^{2}$ pertenciam a migrantes/imigrantes, o que equivale a aproximadamente $80 \%$ do total de entrevistados. No entanto, as entrevistas de aprofundamento revelaram que, dos $20 \%$ de moradores que nasceram nos bairros do EPS, uma parcela ${ }^{3}$ era composta de filhos ou netos de imigrantes. E foi essa informação que levou a pesquisa à percepção de que o EPS não somente no presente, mas também no passado, consistiu em um polo receptor de imigrantes, dos quais se destacaram a presença de quatro principais grupos: os italianos, os galegos, os sírio-libaneses e os portugueses.

Partindo dessas considerações iniciais, aponta-se a seguir a presença, hoje esquecida, de descendentes de grupos de imigrantes que tiveram importantes contribuições para a cidade de Salvador. Essa redescoberta oferece possibilidades de uma revalorização geográfico-histórica que resgate uma parcela da memória das imigrações na capital baiana, presente na própria população que habita o EPS.

A pesquisa teve como uma de suas bases conceituais a teoria das migrações internacionais (MASSEY et al., 1993), e isso permitiu compreender os fluxos imigratórios e, combinada com a perspectiva da Geografia Histórica, a realidade soteropolitana no final do século XIX

\footnotetext{
${ }^{1}$ Este número equivale a aproximadamente $47 \%$ do total de 2.481 unidades cartografadas na área de pesquisa, que teve por referência a Poligonal do Parque Histórico do Pelourinho (BAHIA, 1987). Desse número, cerca de 21\% das edificações pertenciam a instituições ou em estado de ruína e cerca de $13 \%$ se encontravam à venda.

2 Ressalta-se que esse número se torna maior quando multiplicado pelo número de moradores em cada unidade entrevistada.

${ }^{3}$ No momento do levantamento dos dados, não se sabia que parte dos moradores do EPS era descendente de imigrantes, por isso essa parcela não pode ser mensurada quantitativamente, uma vez que o caminho para descoberta se deu por meio das entrevistas de aprofundamento, as quais apontaram a existência desses grupos de imigrantes no passado.
} 


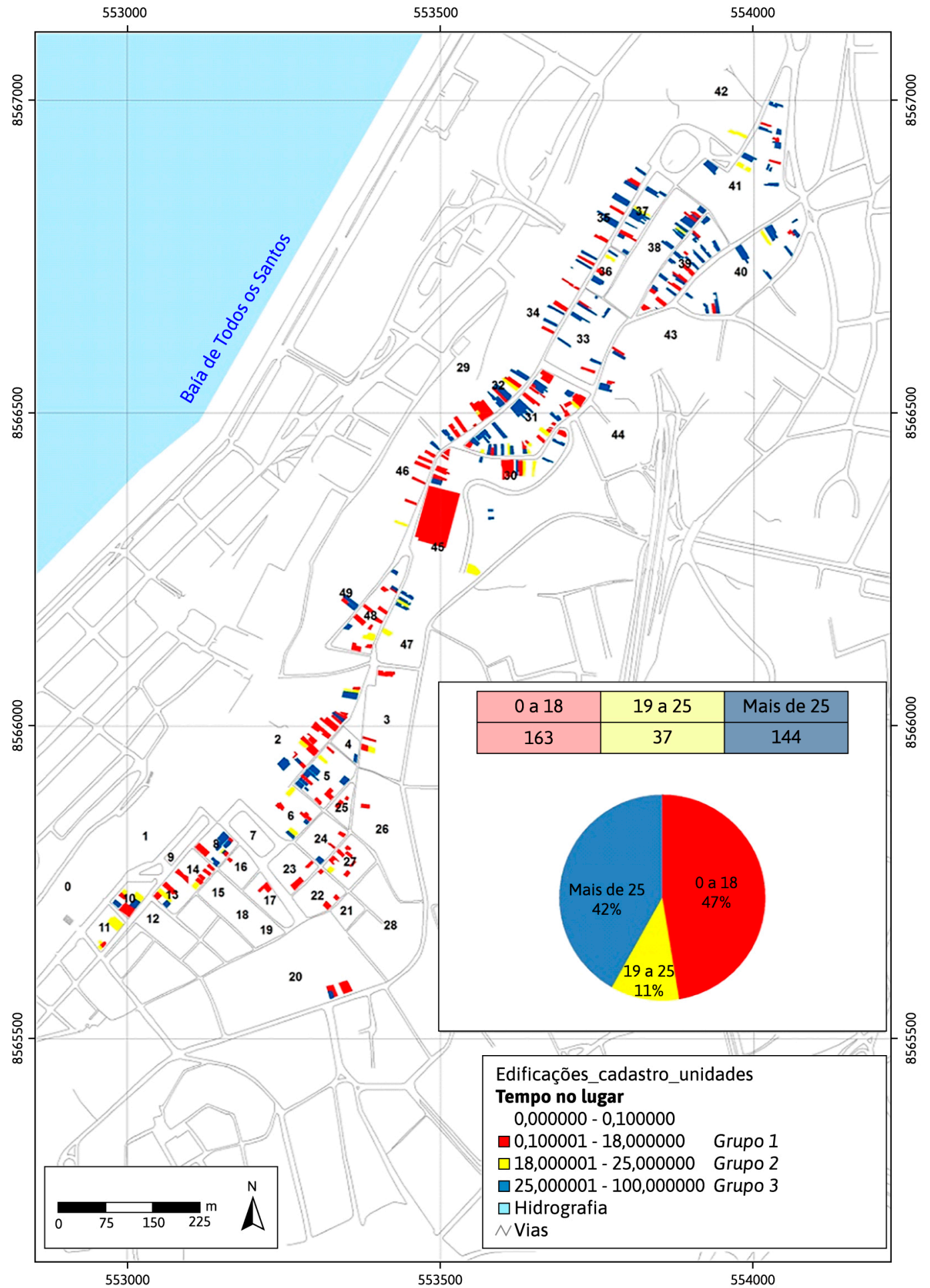

Figura 1 - Tempo de residência no lugar dos moradores do EPS entrevistados em 2011 (RIBEIRO, 2011).

Fonte: elaborada pelo autor a partir de base cartográfica: SICAR RMS 92, Sistema de Coord. SAD 1969, Projeção UTM, 24S 
e início do XX, o que, por consequência, contribuiu para o entendimento do mosaico populacional da área estudada.

Assim, esta análise, traçada sobre as imigrações dos italianos e galegos em Salvador, é parte de um estudo maior que considerou outros grupos populacionais do passado ${ }^{4} \mathrm{e}$ do presente $^{5}$. Ela também é parte de um estudo que se debruçou sobre outras temporalidades, considerando processos socioespaciais urbanos que não serão tratados neste texto, a exemplo da invasão/sucessão e da gentrificação. O enfoque então é dado aos italianos e galegos e, assim, à relação de suas chegadas coincidentes com a centralização ocorrida no final do século XIX e início do século XX e as suas dispersões posteriores.

Vale ressaltar outra premissa lógica traduzida nas palavras de Sayad (1998): de que todo imigrante é também um emigrante. Seguindo esse raciocínio, considera-se que o imigrante que contribui para a existência de um processo socioespacial no lugar em que chega é o mesmo que compõe um processo socioespacial no lugar de onde vem (quando o local de origem faz parte de um fluxo). A relação entre processos socioespaciais e migrações destrincha, assim, o mínimo de três processos concomitantes: migração (como o fluxo em si), emigração (percebido no local de origem como uma dispersão) e imigração (que impacta o local de chegada de diferentes formas). Por fim, a migração pode ter sua origem forjada em conjunturas impulsionadas por outros processos, a exemplo da mundialização.

\subsection{Processos socioespaciais}

No decorrer da pesquisa, observou-se como processos de escala mundial influenciaram a formação de fluxos migratórios que se direcionaram à cidade de Salvador, além da contribuição desses imigrantes para os processos que ocorreram nesse local. Sendo assim, ainda que a análise não se limite a essas duas escalas, ela enfatiza os processos de abrangência internacional e urbanos ${ }^{6}$.

Entre as movimentações geopolíticas internacionais e os territórios que por elas foram atingidos, destaca-se a perspectiva das transformações técnicas como um elemento que possibilitou os fluxos transoceânicos, sendo, assim, um momento anterior à fase da mundialização no seu estágio atual, mas que nem por isso deixou de ser o próprio processo citado.

Autores como Santos (2003) e Harvey (2005) tecem profundas críticas ao processo da mundialização, considerando-a, de acordo com Santos (2003, p. 21), "o ápice do processo de internacionalização do mundo capitalista". Já Harvey (2005) a analisa como um instrumento de expansão do novo imperialismo por meio do qual ocorrem as espoliações dos territórios. Ao mesmo tempo, enquanto Santos (2003) considera a emergência do chamado período popular, Harvey (2005) observa os movimentos de resistência e a construção das utopias como alternativas às imposições do sistema.

Os fluxos imigratórios podem ser interpretados no contexto da expansão capitalista como um produto das desigualdades socioespaciais, mas, quando observados em longo prazo,

\footnotetext{
${ }^{4}$ Portugueses, sírio-libaneses e migrantes de outros estados brasileiros.

${ }^{5}$ Imigrantes oriundos de diversas partes do mundo.

${ }^{6}$ As correntes teóricas macroestruturalistas sobre as imigrações contribuem para a análise em escalas mundiais, a exemplo dos estudos de Singer (1976) e Trewartha (1976). Esta análise fica incompleta se não vier combinada com outras que observam o fenômeno da migração na escala do lugar, como os estudos realizados pela escola de Chicago, a exemplo de Thomas e Znaniecki, em 1918 (THOMAS; ZNANIECKI, 1992), motivo pelo qual a teoria dos sistemas migratórios de Massey et al. (1993) é importante para este estudo.
} 
revelam-se como uma força ativa que, em muitos casos, subverte estruturas das sociedades dominantes, gerando impactos que são traduzidos pelos processos socioespaciais.

Segundo Vasconcelos (2013, p.18), "Os processos e formas socioespaciais são originários das mudanças atuais sobrepostas às inércias do passado". Corrêa $(2005$, p. 37) buscou compreender os processos sociais nas cidades capitalistas, explicando que se trata de: "[...] uma expressão empregada por geógrafos para tentar dar conta do que ocorre no espaço ao longo do tempo". Para ele, cada processo resultará em uma forma espacial, a saber: a área central é produto da centralização; os núcleos secundários são decorrentes da descentralização; as áreas especializadas são geradas pela coesão; as áreas sociais são produto da segregação; e as áreas cristalizadas são resultantes da inércia.

Vasconcelos (2013) aponta a diferença entre processos que se assemelham quanto à forma, mas não são decorrentes da mesma causa. Assim, classifica os processos em: noções ligadas aos espaços; noções relativas aos indivíduos; e noções relacionadas aos indivíduos e aos espaços. Um dos conceitos trabalhados por Vasconcelos (2013, p. 20) e utilizados neste texto é o de dispersão, que "corresponde a uma fuga dos centros das cidades muito valorizados". Assim, a dispersão gera novos núcleos urbanos, com centros de trabalho e residenciais em locais periféricos.

Considerando publicações individuais sobre um processo específico, há variados estudos, a exemplo dos relativos à segregação e à gentrificação ${ }^{i i}$. Dessa forma, para cada processo socioespacial, haverá uma gama de estudos.

Com base nos grupos escolhidos (italianos e galegos) e na temporalidade destacada, que vai do século XIX até metade do século XX, dois processos socioespaciais urbanos serão analisados em conjunto com as imigrações: a centralização e a dispersão. Ressalta-se que esses processos ocorreram com o somatório de outros eventos e com a contribuição de outros grupos populacionais, migrantes brasileiros, além de variados agentes socioespaciais, como o Estado, a Igreja, os promotores imobiliários etc. Logo, os imigrantes não produziram de forma exclusiva os processos em questão, mas participaram deles.

A partir dos registros da presença de imigrantes desde a fundação da cidade, pode-se afirmar que a contribuição, ainda que pontual deles em períodos anteriores ao século XIX, sempre existiu. Contudo, é a partir do século XIX que se intensificaram os fluxos das imigrações para todo o país, fato que está diretamente relacionado com a substituição do trabalho escravo nas terras brasileiras, o que será aprofundado na terceira seção.

\subsubsection{As fases dos processos socioespaciais e as imigrações no EPS}

As imigrações euroasiáticas em Salvador podem ser divididas em quatro fases referentes aos processos socioespaciais urbanos da cidade: a primeira é relativa aos processos de dispersão/centralização e invasão/sucessão, ocorridos no EPS; a segunda fase é a de dispersão dos imigrantes pelo município e pelo estado; a terceira fase corresponde à migração de retorno de alguns grupos e permanência de outros; a quarta fase se refere ao momento atual, no qual se encontram na área estudada os descendentes desses imigrantes (Figura 2).

A primeira fase, caracterizada pela dispersão da elite soteropolitana, é acompanhada pela centralização fundamentada na implantação de novos equipamentos públicos no centro e na busca por seu embelezamento, coincidindo com a chegada dos imigrantes e com a gradativa desvalorização do local, decorrentes do processo de invasão/sucessão.

A segunda fase é a consequência da acentuação do processo de invasão/sucessão no centro e da ascensão econômica de parte dos imigrantes, que encontraram na dispersão 

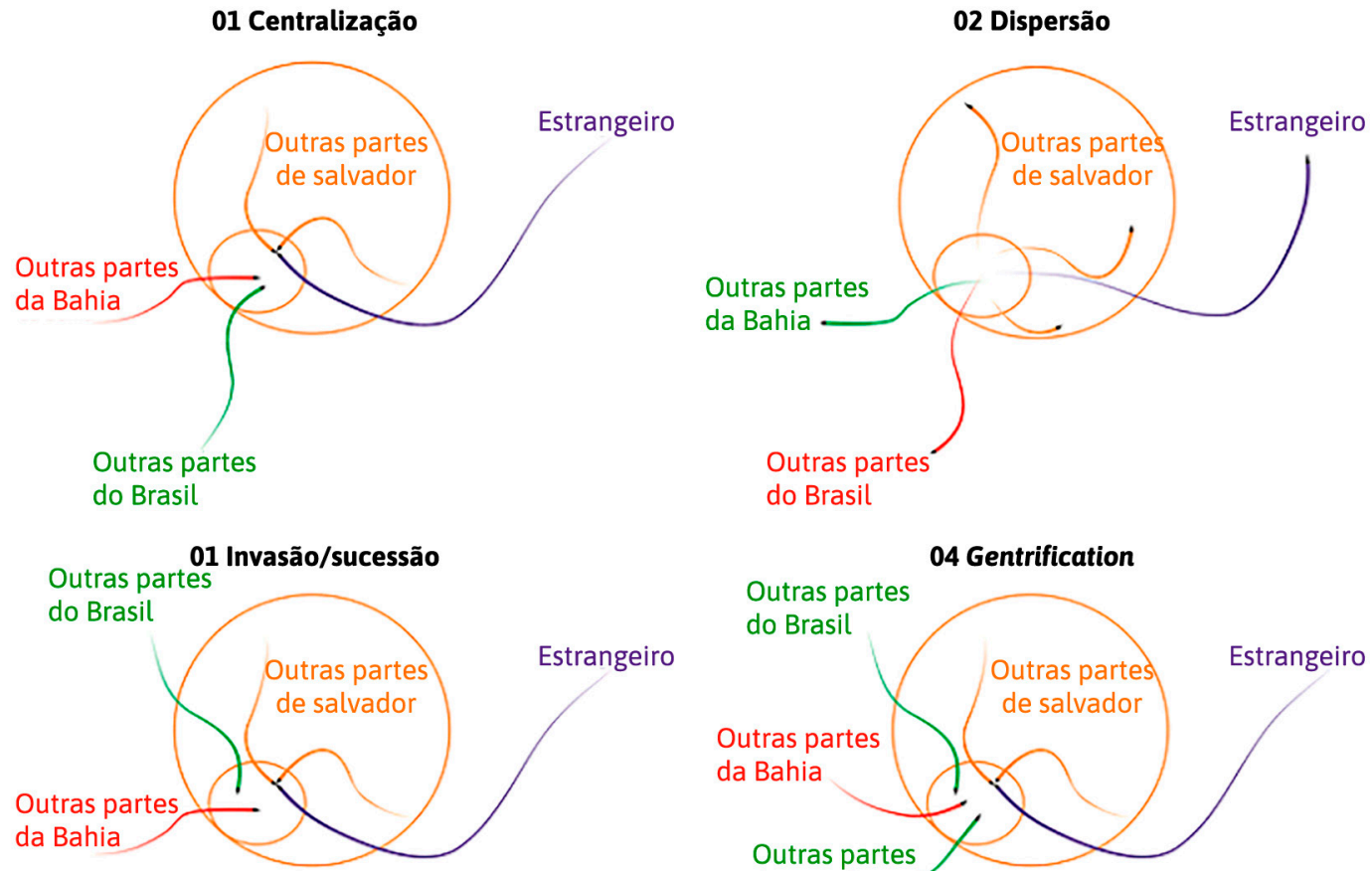
do Brasil

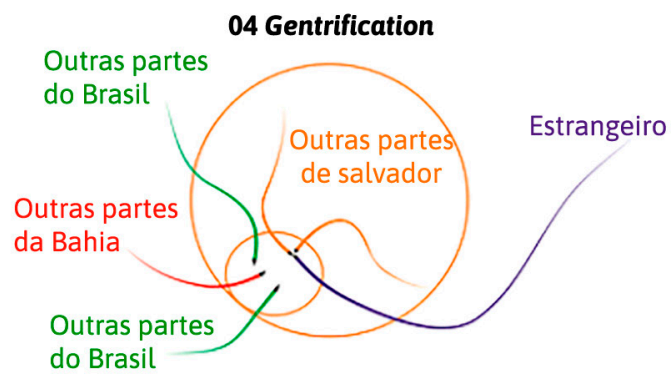

Figura 2 - Relação dos processos socioespaciais com os fluxos migratórios. Fonte: Ribeiro (2018).

pela cidade a melhor estratégia de ocupação territorial. Assim, aqueles que ascenderam economicamente seguiram o movimento da elite soteropolitana de dispersão para o sul de Salvador.

A terceira fase implica um movimento inverso ao da primeira, pois, além de se ampliar a dispersão pela cidade e para fora dela, há um fluxo de retorno de alguns grupos para os países de origem. Muitos dos que retornaram constituíam a segunda e até terceira geração desses imigrantes. Na maioria das entrevistas realizadas, percebe-se que já a segunda geração perdeu o contato com os laços ancestrais, havendo situações em que, inicialmente, os entrevistados não lembravam que tinham avós oriundos de outros países.

A partir de 1985, a tônica no EPS se configurou em torno das requalificações do centro original, o que desencadeou o processo de gentrificação e, com ele, a substituição populacional. Assim, mesclados com os novos moradores que vieram com as ondas de gentrificação, encontram-se os habitantes da população local, composta, em sua maioria, por filhos e netos de migrantes e imigrantes.

Por fim, na quarta fase, não há uma ação direta dos imigrantes, exceto pelo fato da permanência de seus descendentes, resistindo aos processos decorrentes da especulação imobiliária, principalmente a gentrificação.

\section{ANTECEDENTES DOS FLUXOS EMIGRATÓRIOS}

São muitos os fatores que somados explicam a formação dos fluxos migratórios dos italianos, galegos, sírio-libaneses e portugueses para o EPS. Contudo, a teoria pioneira de Ravenstein (1885), contemporânea a esses movimentos populacionais, contribui 
para a compreensão dessas correntes de imigração. De um lado, a instabilidade política e/ou econômica pela qual passavam os territórios habitados pelos grupos em questão, funcionando como áreas de repulsão populacional; do outro lado, o Brasil com políticas para atração de colonos brancos como medida para substituição da mão de obra escrava e branqueamento populacional.

Assim, esta seção pretende traçar um breve panorama sobre o mundo e a cidade de Salvador, para então pontuar a chegada dos primeiros grupos de imigrantes, tendo por base os levantamentos de informação no referencial bibliográfico existente.

\subsection{Transformações técnicas e políticas no mundo}

Alguns aspectos macroestruturais fizeram do mundo no século XIX genuinamente global, como afirma Hobsbawm (1987). O processo de conexão entre os continentes estava mais consolidado, tanto na transmissão de informações como no transporte de produtos e de pessoas. O progresso das técnicas permitiu essa circulação e comunicação cada vez maior e de forma mais rápida. Ravenstein $(1885,1889)$ apontou a existência de fluxos que ocorriam de zonas de repulsão para outras de atração.

Esse progresso técnico permitiu que mais pessoas fossem informadas da existência de áreas promissoras em localidades longínquas e possibilitou os deslocamentos em tempos reduzidos. Desse modo, Castles e Miller (2009) se referem ao século XX como sendo a era das migrações, mas é possível afirmar que ela foi germinada no século XIX.

Hobsbawm (1987) informa que, com exceção da maior parte do território da África, da Ásia continental e partes do interior da América do Sul, "A ferrovia e a navegação a vapor haviam reduzido as viagens intercontinentais ou transcontinentais a uma questão de semanas, em vez de meses". A respeito da comunicação, ele explica que: "Com o telégrafo elétrico, a transmissão de informação ao redor do mundo era agora uma questão de horas". Então conclui que, como decorrência dos progressos na comunicação e transportes: "homens e mulheres do mundo ocidental - mas não só eles - viajaram e se comunicaram através de grandes distâncias com facilidade e em número sem precedentes" (HOBSBAWM, 1987, p. 9).

A integração territorial proporcionada pelos avanços técnicos dos sistemas de comunicação e transportes ainda não havia se disseminado integralmente no território brasileiro, mas, nas capitais das províncias, a comunicação com os outros continentes pelos fluxos transoceânicos já era uma realidade que se intensificava a partir dos progressos técnicos, modificando, inclusive, as relações territoriais no próprio Império. Assim, os fatores técnicos facilitaram o deslocamento e o acesso às informações, combinando-se à instabilidade política vivida em distintas partes do mundo. Fugindo das dificuldades em seus territórios, muitos emigrantes encontraram esperança de ascensão econômica e social na América.

\subsection{O fim da escravidão e a importação de colonos}

Analisando a geografia política mundial, observa-se que, após os eventos que envolveram o bloqueio continental napoleônico, as pressões internacionais, principalmente da Inglaterra, para o fim da escravidão cresciam. Isso afetava diretamente a economia agrária brasileira, que tinha no escravizado o seu "produto" mais caro. A escravidão já havia sido abolida na Europa e "no restante do mundo dominado pelo Ocidente vivia seus derradeiros anos 
até em seus últimos bastiões - Brasil e Cuba - onde não sobreviveu além dos anos 1880" (HOBSBAWM, 1987, p. 21).

Essa pressão internacional encontrou eco na estrutura social brasileira, inclusive com o imperador D. Pedro II, que, ao observar as consequências do término abrupto do sistema escravagista nos Estados Unidos, tinha por planos a transição gradual no país. Ao mesmo tempo, o Estado buscou a substituição da mão de obra escrava com a importação dos colonos brancos. Britto (2004) relata a visita de Dom Pedro II a países como o Líbano no intuito de atrair colonos para o Brasil.

Em conjunto com incentivos e leis decretadas pelo imperador, que visavam findar a escravidão, as elites econômicas de algumas províncias brasileiras se antecipavam ao processo de substituição da mão de obra escrava e buscaram nos colonos estrangeiros a viabilidade para tal.

O projeto de extinguir a escravidão era acompanhado com o da substituição da mão de obra escrava pela de colonos europeus e asiáticos, pois, segundo alguns autores, como Azevedo (1989) e Andrade (1992), a ideia das elites na época era a de que os colonos trariam civilidade para os rincões mais atrasados do país. Esse processo, combinado com o golpe que culminou na República, deixou os recém-libertos sem assistência, o que gerou uma estrutura social problemática e complexa em que os estrangeiros tiveram que se inserir.

Nesse contexto, a Bahia é apontada por Thales de Azevedo como a primeira província brasileira a trazer imigrantes europeus, no caso, os italianos, "quarenta anos antes de outras e antes da crise agrária que ocasionou a substituição do escravo em São Paulo, no Rio Grande do Sul e alhures" (AZEVEDO, 1989, p. 43). Segundo o autor, já se constatava que havia um melhor rendimento na agricultura pelo emprego da mão de obra não escrava.

$\mathrm{Na}$ Bahia, o estado foi um importante agente no sentido de fazer a propaganda e de organizar a vinda de colonos europeus, tendo feito isso em três momentos, sendo que o primeiro se deu com a criação da Companhia de Colonização, cuja finalidade era: "importar colonos europeus de Portugal, Espanha, Itália, Suíça, Alemanha e França, que seriam encaminhados a empregadores que deles necessitassem e para áreas onde aqueles que dispusessem de recursos se estabelecessem como fazendeiros" (ANDRADE, 1992, p. 69).

Se, por um lado, as questões de instabilidade política e/ou econômica nos territórios de onde vieram os imigrantes oferecem importantes elementos para a compreensão de parte dos motivos que proporcionaram a repulsão populacional para o Brasil, por outro as ações governamentais do imperador Dom Pedro II, combinadas com as da província da Bahia, apontam as forças que se movimentaram para fazer deste país e, no caso específico, de Salvador áreas de atração.

Assim, as questões macroestruturais que contribuíram para criar o ambiente propício à vinda dos imigrantes para Salvador são fundamentadas nos progressos técnicos e nas mudanças na estrutura social nacional, pautadas nas transformações geopolíticas internacionais. Cabe agora a análise do contexto soteropolitano.

\subsection{A Salvador do século XIX}

No século XIX, Salvador perdeu gradualmente o posto de principal cidade das Américas, passando a assumir um papel secundário nas relações internacionais brasileiras. Vasconcelos (2002), em seu estudo sobre a capital baiana, avalia o processo de perda de importância política e econômica da cidade, dividindo o século XIX em dois períodos, mas ressalva 
que o desprestígio da cidade começou em 1763, com a transferência da capital para o Rio de Janeiro, quando ela deixou de ser o maior porto exportador do Brasil, passando "para o segundo lugar na exportação (27\%), e na importação (26\%)" (VASCONCELOS, 2002, p. 126). Então, a economia se deslocou para a região Sudeste, e esse processo se agravou com a produção do café de 1820 e 1830.

A Guerra da Independência da Bahia, culminada em 2 de julho de 1823, teve por consequência a emigração da comunidade portuguesa e de importantes comerciantes, que retiraram seus capitais, gerando uma crise econômica para a capital baiana. $\mathrm{Na}$ primeira metade do século XIX, motins e revoltas ocorridas a colocaram em posição antagônica ao regime imperial. Entre 1860 e 1887, sua economia entrou em depressão, como reflexo da crise internacional.

A cidade sofreu abalos por conta de mudanças estruturais em escala mundial. Primeiro com a construção do canal de Suez em 1869, reduzindo a quantidade de navios que passavam no porto soteropolitano. Antes disso, em 1858, a implantação das linhas inglesas de navegação a vapor para o Brasil quebrou a dependência das correntes marítimas e, assim: "Salvador começa a perder sua importância marítima para outros portos, como o de Recife, mais próximo da Europa" (VASCONCELOS, 2002, p. 126).

Ainda, duas guerras afetaram diretamente a Bahia: a de Secessão, nos Estados Unidos, que desencadeou a expansão da cultura do fumo no Recôncavo, e a do Paraguai, para onde foram 18.725 homens da província. Um último evento de impacto econômico foi a crise financeira internacional de 1873/1890, que desencadeou a redução da importação dos produtos baianos.

\subsubsection{Mudanças estruturais em Salvador}

No século XIX, Salvador também passou por mudanças estruturais que criaram lacunas espaciais para os grupos imigratórios que se estabeleceram na cidade posteriormente. Nesse período, o centro perdeu gradativamente a importância, na medida em que os seus principais grupos sociais e econômicos foram para outras localidades.

Áreas de maior prestígio foram surgindo na periferia, a exemplo da Freguesia da Vitória, ao sul da cidade. Após 1808, com a abertura dos portos brasileiros, cresceu a influência dos comerciantes ingleses em Salvador, que encabeçaram a valorização dos jardins, pomares, espaços limpos e ventilados. "Movendo-se em direção ao sul, à Barra, os ingleses foram pioneiros em fazer do Campo Grande e da Vitória morada dos mais ricos, uma tendência descrita por Maria Graham e que persiste até hoje" (PALÁCIOS, 2009, p. 39).

A estrutura espacial soteropolitana foi se modificando. Ao perder parte de sua população, ocorreu a criação de novos quadros no centro, tal como Milton Santos pôde constatar em sua tese de 1958 (SANTOS, 2008). Esse êxodo, iniciado após uma epidemia de cólera, levou a população mais rica a buscar localidades com melhor salubridade, como informa Teixeira (1978).

Ao mesmo tempo, a cidade recebia um fluxo migratório, o qual, como Santos (2008) explica, era o excedente das pessoas de todo o Nordeste, expulsas pela seca. O autor aponta que o impacto dessas correntes migratórias foi atenuado, principalmente, nas quatro primeiras décadas do século XX, quando a zona cacaueira na Bahia substituiu a capital do estado no papel de receptáculo da população nordestina excedentária. 
Os processos relacionados a Salvador, que criaram as bases para o estabelecimento dos imigrantes no EPS a partir de final do século XIX, podem ser sintetizados em seis pontos: $1^{\circ}$ ) a saída populacional do centro; $2^{\circ}$ ) o fim da legalização da escravidão; $3^{\circ}$ ) o incentivo do estado à vinda de colonos estrangeiros; $4^{\circ}$ ) as relações anteriores entre Salvador e os territórios de origem dos migrantes; $5^{\circ}$ ) as transformações técnicas que permitiram maiores fluxos populacionais e de informação no mundo; $6^{\circ}$ ) a saída dos portugueses após a Guerra da Independência, deixando lacuna no comércio.

\section{IMIGRAÇÕES E PROCESSOS SOCIOESPACIAIS}

O impacto das imigrações no EPS ocorreu qualitativa e quantitativamente. Como contribuição qualitativa, entende-se que a imigração tenha se somado material e imaterialmente ao espaço em questão, sendo, assim, presente na paisagem e cultura soteropolitana, mais especificamente no EPS. Já a expressão quantitativa implica um número de imigrantes significativo a ponto de marcar sua presença na sociedade local. A maior presença no EPS dos imigrantes italianos, galegos, sírio-libaneses e portugueses não exclui a ocorrência de outros fluxos imigratórios na cidade ${ }^{7}$.

Ao mesmo tempo, destaca-se a existência de grupos que, quantitativamente, não foram expressivos. Os estudos de Vasconcelos (2002) e Nascimento (1985), por exemplo, trazem citações de franceses, africanos (livres), alemães, suíços, dentre outras nacionalidades; contudo, trata-se de presenças pontuais. Apenas como um dos variados exemplos encontrados, pode-se citar a passagem em que Nascimento (1985, p. 70) comenta a respeito da Freguesia da Sé (uma das freguesias que compõem o EPS), onde o quarteirão número 20, apesar de apresentar diversas categorias sociais, sobrepujava o comércio elitista, do qual: "As casas comerciais se sucediam, às vezes vizinhas, às vezes espaçadas, gerenciadas a maior parte delas por estrangeiros".

Ainda é valido mencionar que, no contexto escravocrata, os grupos de africanos escravizados e seus descendentes compunham a maior parcela da população de toda a cidade de Salvador. Salienta-se que grande parte de seus descendentes foi marginalizada e excluída do acesso a terra e a outros direitos sociais, ao mesmo tempo que no país se criavam as políticas de importação dos colonos brancos.

\subsection{Dispersão: portugueses e ingleses}

Como já mencionado, o primeiro movimento de dispersão do EPS ocorreu com a saída dos ricos comerciantes ingleses e portugueses seguidos pela população mais abastada da cidade. Outro fator que se somou a isso foi a expulsão dos ricos comerciantes portugueses, após a Guerra de Independência da Bahia. Com esses dois movimentos de dispersão, havia lacunas habitacionais que, posteriormente, seriam preenchidas pelas famílias de imigrantes em ascensão comercial.

Ressalta-se que, com a crescente pressão pelo fim da escravidão, já se iniciavam no século XIX as políticas de importação de colonos. É nesse contexto que será observada a chegada dos italianos e galegos.

7 Com a abertura dos portos brasileiros, os ingleses, por exemplo, tiveram a sua presença na parte nobre da cidade, conhecida como Corredor da Vitória, havendo nas suas proximidades, inclusive, um Cemitério dos Ingleses. Outro grupo identificado foi o dos japoneses (MAEKAWA, 2002), mas eles, de fato, formaram colônias agrícolas no interior do estado. Contudo, nas entrevistas e pesquisa documental, encontramos relatos pontuais de japoneses habitando o EPS. 


\subsection{Imigração italiana, centralização e dispersão}

Como já afirmado, a Bahia foi a primeira província brasileira a trazer imigrantes italianos, visando à substituição da mão de obra escrava, 40 anos antes de outras. Assim como as províncias que a sucederam, o destino desses colonos seria o das áreas rurais, conforme afirma Azevedo (1989).

No entanto, é importante ressaltar que, assim como galegos e portugueses, a presença dos italianos em Salvador antecedeu o momento histórico da importação de mão de obra europeia. Ainda, Thales de Azevedo (1989, p. 29) menciona que, em 1820, já existia uma pequena colônia italiana na cidade de Salvador, "formada em grande parte por mercadores genoveses, justamente da região com a qual se fazia o referido tráfego marítimo". Segundo o autor, a formação dessa colônia poderia estar relacionada com as lutas pela libertação da Bahia ${ }^{8}$ no século XVII, "das quais havia participado um corpo do exército napolitano" (AZEVEDO, 1989, p. 29).

Benedini (2013, p. 1) informa que "em 1850, o consulado da monarquia piemontesa estimava em acerca de 150 o número de súditos" que residiam em Salvador, em suas pesquisas nos arquivos públicos da cidade o autor identificou que a partir de 1850 ocorreu o aumento de registros desses imigrantes pela polícia portuária. Apesar do ponto de chegada ser em Salvador e de muitos dos imigrantes italianos se instalarem na capital baiana, uma parte considerável desses imigrantes se dirigiam para o interior. Trento (1988) estima que a colônia italiana era a mais numerosa do estado no final do século XIX, estando na faixa de 3000 colonos.

Andrade (1992) explica que os primeiros imigrantes italianos chegaram no início do século XIX e formaram uma corrente imigratória. Grande parte desses imigrantes se transferiu para o interior, "embora a maioria ficasse em Salvador" (idem, p. 68). Entre os seus destinos, o autor menciona Belmonte, "que chegou a ter até, 1896, um agente consular" (ibidem). Também relaciona o sul da Bahia com a cultura cacaueira, que "nos fins do século XIX e início do XX viveu um período de grande produção e acumulação de riqueza, tendo atraído estrangeiros de diversas nacionalidades" (ibidem). Existem ainda cidades no sul baiano cuja população é, em sua maioria, composta por descendentes de italianos, a exemplo de Jaguaquara e Jequié.

Outro elemento da imigração italiana em Salvador termina por se repetir com os demais grupos estudados e diz respeito aos ofícios, com destaque para os relativos ao comércio. Assim, além das prestações de serviços realizados na capital baiana, uma parte dos comerciantes italianos ia periodicamente ao interior, trabalhando como mascates, mas também levando e trazendo informações de um ponto ao outro.

Segundo Azevedo (1989, p. 34), no EPS a avenida conhecida como Baixa dos Sapateiros era famosa pela "expressiva existência de lojas de italianos", das quais se destacavam os negócios de sapataria, fazendas, miudezas e oficinas mecânicas. Ainda, Azevedo (1989, p. 40) menciona a existência de outros ofícios, como os de "artesãos, operários, lavradores, mestres de obra, arquitetos, músicos, industriais, comerciantes, pintores, missionários", e conclui afirmando que "a presença italiana na Bahia têm sido marcada igualmente por pensadores e intelectuais de valor até agora pouco notados".

${ }^{8}$ No dia 9 de maio de 1624, Salvador foi invadida pelos holandeses, sendo libertada por tropas lusitanas no dia 27 de maço de 1625 . 
Nesse aspecto, ressalta-se que alguns italianos no estado chegaram a um certo grau de influência, que um de seus descendentes, Antônio Lomanto Junior (nascido em Jequié), tornou-se governador da Bahia. Também é possível destacar a presença italiana em outra instituição detentora de poder, a Igreja. Os padres italianos contribuíram com as igrejas seculares ou nas ordens religiosas (a exemplo dos salesianos) e tiveram expressão em Salvador.

No campo das artes, os imigrantes italianos imprimiram suas contribuições na paisagem da cidade, principalmente a partir de 1912, quando o governador J.J. Seabra trouxe de São Paulo arquitetos, escultores, pintores e decoradores especializados "com o fito de mudar, como pretenderam e em parte conseguiram, a grave e tranquila fisionomia plástica de Salvador" (AZEVEDO, 1989, p. 32). Entre os artistas, é possível destacar alguns nomes, como Chirico, Conti, Santoro, Rossi, Scorcelli. Outro campo de destaque foi o da música, uma vez que os italianos atuaram como pianistas ou professores de piano, cantores de ópera, entre outros ofícios musicais. O grupo chegou a publicar óperas italianas nos jornais que circulavam na cidade.

Ainda que conservando uma forte presença em algumas cidades baianas, como as já citadas Jequié e Jaguaquara, a colônia italiana em Salvador teve seu número reduzido após o episódio do bombardeamento de navios brasileiros durante a Segunda Guerra Mundial, causando, por consequência, a revolta da população soteropolitana, que depredou estabelecimentos italianos e alemães na cidade. Tal evento fez com que muitos desses imigrantes se mudassem da cidade. Isso se somou aos movimentos de dispersão que já ocorriam nas décadas precedentes à de 1940 .

Outro fator que contribuiu de forma geral para a redução de imigrantes no país e de italianos em Salvador foi o estabelecimento da Lei de Cotas de Imigração (BRASIL, 1934). Contudo, é possível comparar diferentes grupos e observar que, no caso daqueles que já possuíam uma maior quantidade de membros na cidade, após o estabelecimento das cotas os fluxos continuaram a ser expressivos, que é o caso dos galegos.

\subsection{Imigração galega}

Segundo Braga (1995), os três primeiros imigrantes galegos chegaram a Salvador no ano de 1883, todavia é possível contestar essa afirmação. Bacelar (1994) informa que, no consulado espanhol em Salvador, há registros de galegos estabelecidos na cidade desde 1861. Já Brandão (2005) esclarece que 1883 é o ano oficial para a chegada dos galegos. Nos primeiros anos, esse grupo se estabeleceu "quase que exclusivamente no então degradado Centro Histórico de Salvador ou no seu entorno imediato, abandonado pelas elites locais [...]" (BRANDÃO, 2005, p. 20). Após algum tempo, o grupo foi se dispersando pela cidade, não ficando concentrado em um único espaço, ao contrário de outros grupos.

Para Brandão (2005), isso foi reflexo da estratégia de sobrevivência, pois, se, inicialmente, a proximidade espacial entre os membros foi importante para que conseguissem se estabelecer na cidade, posteriormente se tornou um fator limitante no seu objetivo de inserção na sociedade soteropolitana. Era necessário reduzir as distâncias sociais e empáticas, por isso "Habitar o degradado Centro Histórico não era, portanto, algo que contribuísse com a integração do grupo" (BRANDÃO, 2005, p. 82).

Mantendo vínculo com sua aldeia de origem e considerando a emigração para Salvador como um passo temporário em suas vidas, já que pretendiam retornar à terra natal, os 
galegos criaram laços entre Salvador e a Galícia, que se estenderam pelas gerações, de modo que, após a estabilização econômica e política da Espanha, iniciou-se uma migração de retorno. Esse vínculo, ao mesmo tempo que fundamentou o fluxo em questão, constituiu entraves na inserção dos galegos na sociedade soteropolitana

O perfil dos imigrantes galegos que chegaram a Salvador era bem definido, sendo, na maioria dos casos, jovens do sexo masculino e majoritariamente oriundos dos ayuntamientos de Ponte Caldelas, Fornelos de Montes, A Lama e Pazos de Borbén.

Esses imigrantes vinham sozinhos e retornavam para suas aldeias de origem para se casar. Em muitos casos, não traziam suas esposas para o Brasil, mantendo-as com a família na própria Galícia. "Muitas vezes, passavam anos indo à Galícia periodicamente, mas só depois de vários anos é que traziam a família" (BRAGA, 1995, p. 94-95). Esse é um dos elementos que explica o laço com a terra natal, assim como os investimentos que se dividiam entre Salvador e a Galícia.

Braga (1995) afirma que o galego em Salvador veio de forma isolada, entrando na cidade, muitas vezes, ilegalmente, fato que dificultava uma precisão correta da quantidade de imigrantes na cidade durante o século XX. Bacelar (1994) comenta que a hostilidade encontrada exigiu que a mão de obra nos estabelecimentos tivesse que ser dos próprios conterrâneos, trazidos da Espanha. O preconceito com o brasileiro - mais explicitamente com os negros - foi um fator que se somou a isso. Por fim, associar-se com os baianos dificultaria o enriquecimento.

Analisando os aspectos sociais familiares desses imigrantes, Braga (1995) identificou que eram famílias grandes, com cerca de oito a dez filhos, algo comum na realidade rural de onde vinham. No processo de inserção na vida urbana em Salvador e de progressão econômica e social dos galegos na sociedade soteropolitana, observa-se que há uma mudança na estrutura familiar deles, pois, em 1970, o quadro familiar dos galegos passou a se constituir de três a quatro pessoas.

Sobre o grau de instrução, havia um elevado percentual que só dispunha do nível elementar, tendo muitos deles conseguido a formação do ensino médio em Salvador. A autora lembra que a idade com que a maioria saía da Galícia não permitia um grau de formação superior ao mencionado. No entanto, a ascensão social dos galegos é observável em seus descendentes. Os dados levantados por Braga (1995) apontam que, no momento de sua pesquisa, todos os filhos desses imigrantes possuíam ensino superior - em 1995, o acesso ao nível superior no Brasil era mais restrito do que nos tempos atuais.

\subsubsection{A dinâmica comercial e social dos galegos em Salvador}

No início do século XX, os galegos já haviam dominado o setor alimentício varejista em Salvador, contudo tiveram que lidar com hostilidades que surgiram a partir da crise de abastecimento pela qual ela passou. Bacelar (1994) explica que a cidade tinha como um dos seus problemas crônicos o abastecimento de alimentos, o que a tornou dependente das importações para suprir isso.

Essa escassez de produtos básicos gerou um dos grandes desafios da sociedade naquele período, o da alimentação. Isso desencadeou uma forte tensão social culminante com protestos. Os galegos, componentes das camadas sociais populares, dominavam as 
atividades comerciais em armazéns $^{9}$ e padarias; assim, foram utilizados como alvos pela burguesia soteropolitana, que buscava desviar a atenção do real problema nos altos preços dos produtos.

Enquanto a população se revoltava com os retalhistas (em sua maioria galega), a alta burguesia permanecia tranquila e, assim, soube usar habilmente o principal veículo de informação da época - os jornais - para acusar os galegos de enriquecimento à custa da exploração do povo da cidade.

Relatando os protestos realizados pela população, com destaque para um episódio em 1919, conhecido como "fecha-fecha do pão", no qual diversos estabelecimentos de galegos foram fechados, Bacelar (1994) explica que a estratégia dos atacadistas baianos foi profícua. Para ele, o fato de os galegos terem substituído os antigos comerciantes portugueses foi uma grande vantagem para a burguesia soteropolitana, pois permitiu: "ter alguém na 'linha de frente' da 'populaça', da 'massa ignara' contida, mas potencialmente irada". Além disso, com essas ações, foi possível "fechar um dos canais valorizados - o emprego no comércio - e proporcionadores de ascensão para os grupos negros e pobres da cidade" (BACELAR, 1994, p. 71).

Bacelar (1994) cita os jornais A Tarde e O Imparcial como aqueles que atacavam constantemente os estabelecimentos galegos, e essa prática se intensificou durante a Segunda Guerra Mundial. Portanto, apesar de as hostilidades serem voltadas para os italianos, alemães e japoneses, elas não excluíram os espanhóis.

Neste contexto, os galegos viram a necessidade de se organizar socialmente. Buscando se firmar na sociedade soteropolitana, 124 sócios fundaram a Real Sociedade Espanhola de Beneficência em $1^{\circ}$ de janeiro de 1885 no Campo dos Mártires (atual Campo da Pólvora), situado no entorno do centro original da cidade. Já em 1897, a sua sede institucional foi transferida para o sul da cidade, na Barra, revelando tanto a sua ascensão econômica quanto o empenho por se estabelecer socialmente.

A mesma situação ocorreu com o Cassino Espanhol, fundado no ano de 1910 no Largo da Piedade e transferido, em 1948, para o Corredor da Vitória com o nome de Centro Espanhol, passando depois para a Avenida Oceânica, na Barra. Esse trajeto aponta o deslocamento do centro de convivência dos galegos para o sul da cidade e, como já comentado, a saída do entorno do centro, menos valorizado, para os espaços de expansão aos quais os mais abastados se dirigiam (Figura 3).

Assim, a imigração galega em Salvador somou-se ao processo de centralização entre os anos de 1880 e 1930, ao mesmo tempo que os membros dessa comunidade, uma vez estabelecidos na cidade, compunham o processo de dispersão para outras áreas da capital baiana.

Por causa do grande fluxo que se estabeleceu entre a Galícia e Salvador, apesar da dispersão para outras partes da cidade, a presença galega no EPS continuou a ser expressiva. Com a pesquisa de campo e informações retiradas dos livros que abordaram a imigração galega em Salvador, catalogou-se só no centro original de Salvador e seu entorno a existência de 125 estabelecimentos comerciais, cujos proprietários eram galegos -

\footnotetext{
9 Os estudos de Gandon (2010) apontaram o quadro dos grandes comerciantes varejistas na cidade e a composição das diretorias das associações comerciais. Chama a atenção que, apesar de a composição dispor de uma diversificação das nacionalidades (chegando a existir uma diretoria formada em sua maioria por estrangeiros), não identificamos a presença de galegos nessas diretorias, o que indica que, mesmo com uma ascensão horizontal nas primeiras décadas do século XX, esse grupo ainda compunha (pelo menos socialmente) as camadas populares da cidade.
} 


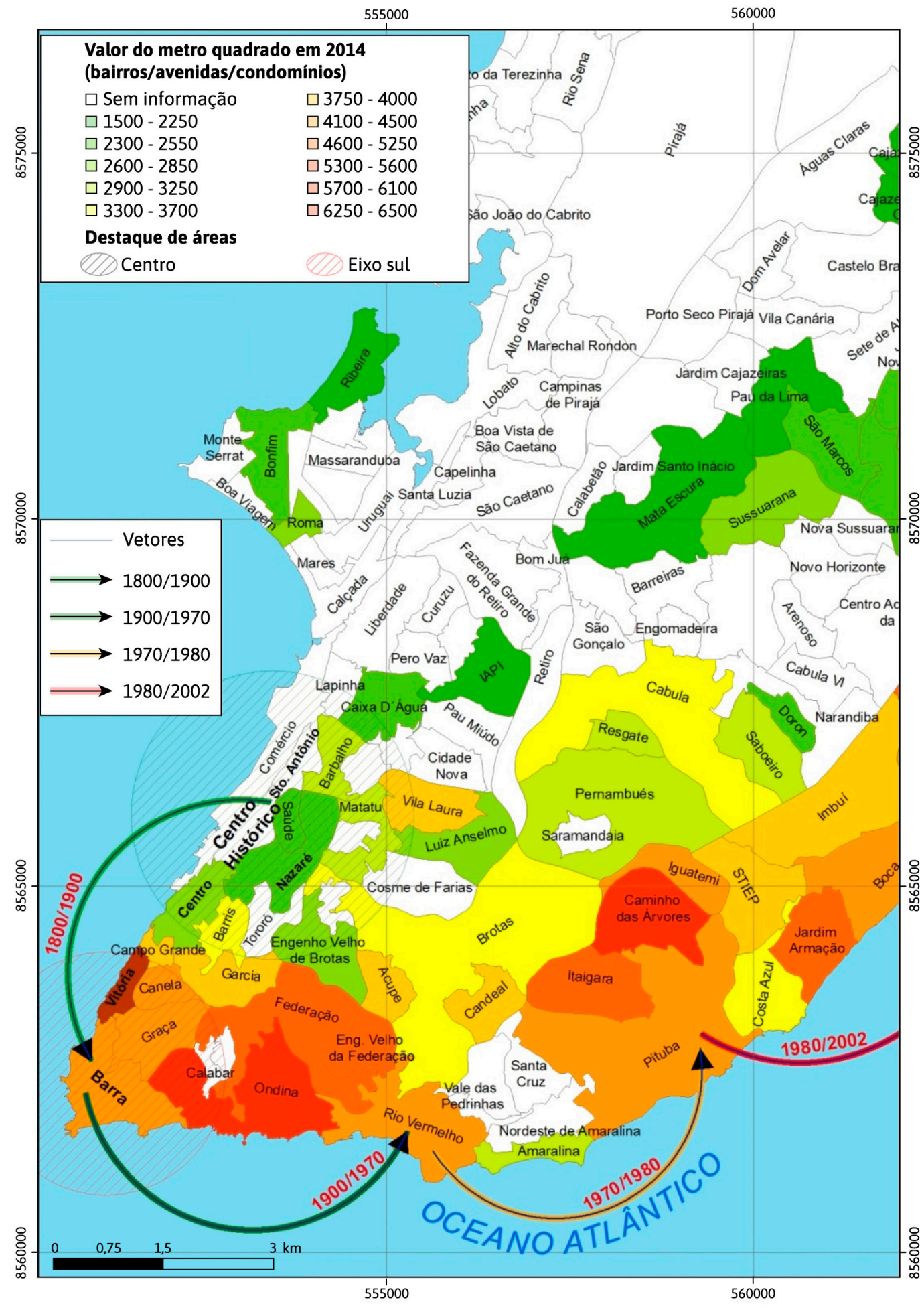

Figura 3 - Especulação imobiliária em Salvador, com os vetores de dispersão da classe média e média alta. Fonte: elaborada pelo autor a partir de base cartográfica: SICAR RMS, Projeção geográfica SAD_1969, UTM, Zona 24S. 
e essa lista não considerou as unidades residenciais. Vale ressaltar também que a principal fonte dessas informações (LEAL, 2002) tabulou os estabelecimentos referentes ao século XX.

A situação econômica e social galega parecia se estabilizar, com parte desses imigrantes ascendendo social e economicamente e com a sua predominância comercial em estabelecimentos como padarias, armazéns e pastelarias. Contudo, um grande concorrente trouxe forte crise para os galegos.

Em 1959, o comerciante sergipano Mamede Paes Mendonça inovou em Salvador ao trazer, de forma pioneira, o supermercado, inaugurado no bairro de Nazaré. Isso abalou diretamente o principal setor dominado pelos galegos: a venda de secos e molhados. Os supermercados tinham uma grande estrutura e condições de vender mais barato que as feiras e armazéns soteropolitanos, os quais foram afetados de imediato com a perda de clientes, o que foi se acentuando de forma progressiva, na medida em que o acesso ao supermercado crescia e chegava aos mais humildes, em razão de sua expansão espacial na cidade, com a abertura de novas unidades, e por causa do acesso ao crédito.

Somente a população de baixa renda continuava comprando nos armazéns, mas depois nem mesmo eles. Quando as padarias foram instaladas nos supermercados, a situação se tornou insustentável para os comerciantes galegos. Esse panorama os forçou a se reinventarem, caso não quisessem amargar a falência. Então, aqueles que tinham capital acumulado conseguiram mudar de empreendimento para fugir da crise.

A partir da década de 1960, dois fortes movimentos aconteceram no que concerne aos galegos. O primeiro era relacionado diretamente com a mudança na atuação empresarial. Muitos comerciantes, ao trocarem de ramo, enriqueceram, e alguns deles investiram em setores estratégicos da cidade, como o dos transportes e da construção. O segundo ponto ocorreu a partir de 1970 e, principalmente, na década de 1980, quando, em razão da crescente estabilização política e econômica na Espanha, iniciou-se um movimento de retorno da comunidade galega, havendo, assim, uma considerável redução de sua presença na cidade de Salvador. Tal movimento, percebido na cidade como um processo de dispersão, consistiu em uma migração de retorno, o que, no caso específico do EPS, gerou novas lacunas no centro, as quais possibilitaram a intensificação dos processos de sucessão/invasão, criando o quadro para o que posteriormente se configurou com a gentrificação em Salvador.

\section{CONSIDERAÇÕES FINAIS}

A Geografia Histórica das migrações italianas e galegas em Salvador traz em seu cerne o panorama das transformações pelas quais passava o mundo e se insere no contexto do processo da mundialização, o qual aponta um elemento básico dos fluxos migratórios: a existência de desigualdades territoriais em todo o planeta.

A comparação de estudos da geografia urbana e da geografia da população, tendo por alicerce a Geografia Histórica, permitiu a constatação de que os processos socioespaciais urbanos estudados na escala urbana podem ter, no que se refere à população, forte contribuição dos fluxos migratórios.

A comparação da imigração dos dois grupos permite constatações de similaridades e diferenças no seu desenvolvimento. Quanto às similaridades, que podem ser estendidas 
aos outros dois grupos de maior relevância (portugueses e sírio-libaneses) para a área destacada na pesquisa, que é o EPS, uma delas é a da coincidência dos fluxos imigratórios que ocorreram no final do século XIX e início do século XX com os processos de centralização e, posteriormente, de dispersão. Ainda nas relações desses processos socioespaciais urbanos, evidenciou-se que os próprios fluxos imigratórios foram gerados por processos de escala mundial.

Com pouco mais de um século em que os fluxos de italianos e galegos para Salvador ocorreram, constatou-se que, encontrando espaço no comércio, muitos desses imigrantes conseguiram ascender socialmente na capital baiana. Tendo melhorado suas condições econômicas e sociais, muitos dos já enriquecidos mudaram de áreas menos valorizadas para outras onde a cidade moderna e rica crescia. Contudo, o processo socioespacial de dispersão não necessariamente se deu somente para outras partes da cidade, mas também para fora dela.

A principal diferença a se destacar é que, enquanto a presença galega se mesclou à de outros grupos populacionais no mosaico étnico-racial soteropolitano, a presença italiana na paisagem humana do EPS se fez imperceptível, ainda que possivelmente estivesse mesclada nos genes de alguns de seus habitantes. No entanto, os italianos se eternizaram na história e, principalmente, na paisagem urbana do EPS, em razão das contribuições dos artistas contratados para a modificação plástica das faixadas dos casarões da capital baiana e ao mesmo tempo com as estátuas e outras obras plásticas encravadas no coração da cidade. Já as estruturas construídas pelos galegos são mais do que formas, uma vez que, em muitos casos, ou preservaram as suas funções ou foram ressignificadas pelo próprio grupo.

Por fim, ressalta-se a importância de romper com os velhos paradigmas perpetuados pela historiografia tradicional e apontar novas perspectivas para as pesquisas sobre as imigrações no Brasil, primeiramente reconsiderando os marcos temporais, a exemplo do que alguns autores ainda afirmam ser o início das correntes imigratórias dos italianos para o país, e, em segundo lugar, evidenciando outros territórios como sendo polos receptores de imigrantes, inclusive no passado, como é o caso de Salvador, Bahia.

\section{REFERÊNCIAS}

ANDRADE, M. C. A Itália no Nordeste, contribuição italiana ao Nordeste do Brasil. Recife: Editora Massangana, 1992.

AZEVEDO, T. Italianos na Bahia e outros temas. Salvador: EGBA, 1989.

BACELAR, J. Galegos no Paraíso Racial. Salvador: UFBA, 1994.

BAHIA. Decreto estadual no 7.984 de 04 de setembro de 1987. Diário Oficial do Estado da Bahia, 1987.

BENEDINI, G. F. A emigração italiana para a Bahia. Fênix: Revista de História e Estudos Culturais, Uberlândia, v. 10, n. 2, p. 1-20, 2013.

BIDOU-ZACHARIASEN, C. B.; NICOLAS, D. H.; d' ARC, H. R. (Ed.). De volta à cidade: dos processos de gentrificação às políticas de "revitalização" dos centros urbanos. São Paulo: Annablume, 2006.

BRAGA, C. M. L. Memórias de Imigrantes Galegos. Salvador: Centro Editorial e Didático da UFBA, 1995. BRANDÃO, P. R. B. Geografias da presença galega na cidade da Bahia. Salvador: EDUFBA, 2005.

BRASIL. Lei no 24.215, 9 de maio de 1934. Diário Oficial da República Federativa do Brasil, Brasília, DF, 1934.

BRITTO, L. R. R. Os Primos: crônica de uma família libanesa na Bahia. Salvador: Gráfica Santa Helena, 2004. CASTLES, S.; MILLER, J. The age of migration. 3rd ed. New York: Guilford Press, 2009.

CORRÊA, R. L. O espaço urbano. 4. ed. São Paulo: Ática S.A., 2005. 
GANDON, T. R. A. Portugueses na Bahia na segunda metade do séc. XIX, emigração e comércio. Salvador: EDUNEB, 2010.

HARVEY, D. O Novo Imperialismo. 2. ed. São Paulo: Loyola, 2005.

HOBSBAWM, E. The age of empire: 1870 -1914. London: Vintage USA, 1987.

LEAL, G. C. Perfis urbanos da Bahia, os bondes, a demolição da Sé, o futebol e os galegos. Salvador: Gráfica Santa Helena, 2002.

MAEKAWA, L. Os japoneses na Bahia. Salvador: Dankat Gráfica, 2002.

MASSEY, D. S. et al. Theories of international migration: a review and appraisal. Population and Development Review, New York, v. 19, n. 3, p. 431-466, 1993.

NASCIMENTO, A. A. V. Dez freguesias da cidade do Salvador. Salvador: Empresa Gráfica da Bahia, 1985.

PALACIOS, M. G. L. S. A Reforma do Pelourinho, o período pré-1992. Belo Horizonte: UFMG, 2009.

RAVENSTEIN, E. G. The laws of migration. Journal of the Royal Statistical Society, London, v. 52, n. 2, p. 241-305, 1889.

RAVENSTEIN, E. G. The laws of migration. London: Blackwel Publishing for the Royal Statistical Society, 1885.

RIBEIRO, D. A. Gentrification no Parque Histórico do Pelourinho, Salvador - Bahia. Dissertação (Geografia)-UFBA, Salvador, 2011.

RIBEIRO, D. A. Migrações para o Eixo Pelourinho Santo Antônio. Tese (Geografia)-UFBA, Salvador, 2018.

SANTOS, M. Por uma outra globalização: do pensamento único à consciência universal. 10. ed. Rio de Janeiro: Record, 2003.

SANTOS, M. O centro da cidade do Salvador. Salvador: Livraria Progresso Editora, 2008.

SAYAD, A. A imigração ou os paradoxos da alteridade. São Paulo: Editora da Universidade de São Paulo, 1998.

SINGER, P. I. Dinâmica populacional e desenvolvimento: o papel do crescimento populacional no desenvolvimento econômico. 2. ed. São Paulo: Hucitec, 1976.

SMITH, N. The new urban frontiers: gentrification and the Revanchist City. New York: Routledge, 1996.

TEIXEIRA, C. As grandes doações do $1^{\circ}$ governador. In: A Grande Salvador. Salvador: Cedurb, 1978.

THOMAS, W. I.; ZNANIECKI, F. The polish peasant in Europe and America: monograph of na immigrant group. Ithaca: Cornell University Library, 1992.

TRENTO, A. Do outro lado do Atlântico: um século de imigração italiana no Brasil. São Paulo: Nobel, 1988.

TREWARTHA, G. T. Geografia da população, padrão mundial. São Paulo: Atlas, 1976.

VASCONCELOS, P. A. Salvador: transformações e permanências (1549-1999). Ilhéus: Editus, 2002.

VASCONCELOS, P. A. Contribuição para o debate sobre os processos e formas socioespaciais nas cidades. In: VASCONCELOS, P. A.; CORREA, R. L.; PINTAUDY, S. M. (Ed.). A cidade contemporânea, segregação espacial. São Paulo: Editora Contexto, 2013.

SOBRE O AUTOR

Daniel de Albuquerque Ribeiro (RIBEIRO, D. A.). Bolsista Programa Nacional de Pós-doutorado PNPD/CAPES no Programa de Pós Graduação em Geografia da UFF-Campos. Membro do Grupo de Estudos e Pesquisas de Geografia Histórica (Geohistórica).

Notas de fim

i No livro A Cidade Contemporânea Segregação Espacial (VASCONCELOS, 2013), é possível encontrar diferentes abordagens sobre o tema a partir da visão de conceituados pesquisadores em distintas universidades brasileiras.

ii Tendo Smith (1996) como principal referência para os estudos sobre o tema, a gentrificação vem sendo estudada por diversos autores. O livro De Volta a Cidade (BIDOU-ZACHARIASEN; NICOLAS; D’ ARC, 2006) é um exemplo de coletânea contendo diferentes estudos de casos sobre gentrificação no mundo. 
SEÇÃO III

\section{Produção do espaço, agentes e dinâmicas}




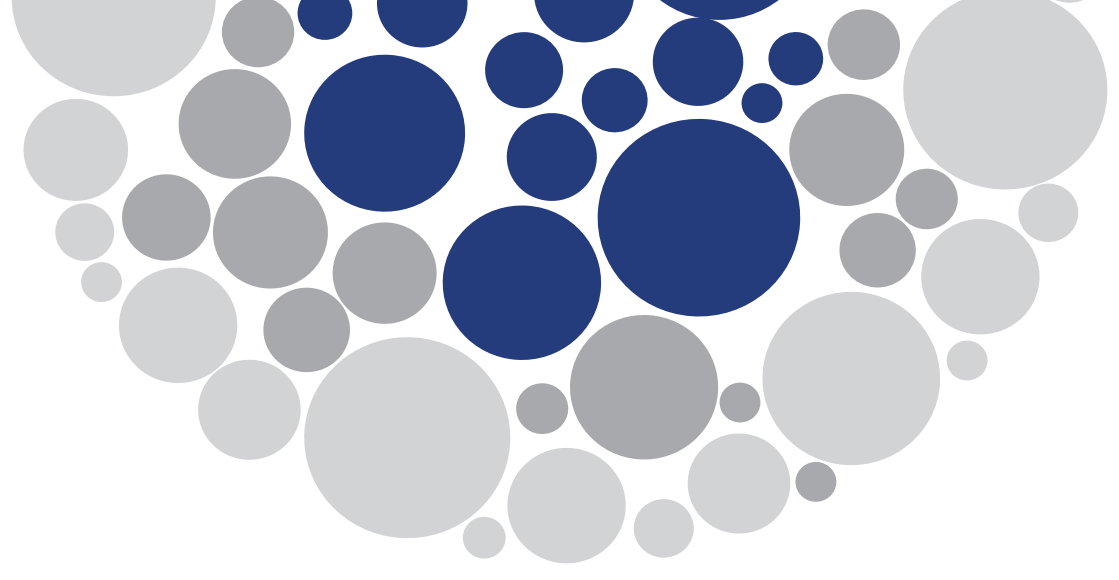

\title{
Escola Quilombola de Quissamã e bairros negros de Itaperuna: para pensar no racismo estrutural
}

\begin{abstract}
Felício Alves de Azeredo ${ }^{a}$, Marcia Aparecida Pereira de Mellob ${ }^{b}$ Edimilson Antônio Motac
a Universidade Federal Fluminense/Programa de Pós-Graduação em Geografia da UFF/CAMPOS. E-mail: felicioalves@id.uff.br b Universidade Federal Fluminense/Programa de Pós-Graduação em Geografia da UFF/CAMPOS. E-mail: marciamgg@gmail.com c PPG UFF Campos, Núcleo de Ensino e Pesquisa sobre Espaço e Currículo de Geografia e Imagem e Multiculturalismo NEPECGIM. E-mail: uffmota@gmail.com
\end{abstract}

A educação no Brasil se desenvolveu de forma elitista e excludente e, nos dias atuais, é gerida em todo o território nacional pelo Ministério da Educação (MEC), órgão responsável pelas políticas nacionais de educação de toda a rede de ensino pública e privada. A Educação Escolar Quilombola, garantida pela Resolução no 8/2012 (BRASIL, 2012), do Conselho Nacional de Educação (CNE), que definiu as Diretrizes Curriculares Nacionais para a Educação Escolar Quilombola na Educação Básica (DCNEEQ), é uma modalidade ofertada em escolas situadas em territórios quilombolas, com o objetivo de manter a cultura, os costumes e as tradições existentes dessa população no Brasil, o que facilitaria aos discentes uma aproximação com a história de seus ancestrais.

O sociólogo francês Pierre Félix Bourdieu (1996) afirma que lidar com a cultura na educação é um meio de nutrir o processo de aprendizagem dos discentes, levando-os à criticidade e ao sentimento de pertencimento ao meio em que estão inseridos. Bourdieu ainda diz que é impensável trabalhar a educação dissociada da cultura. Assim, as questões étnico-raciais, quando trabalhadas no processo de ensino e aprendizagem possibilitam combater o racismo estrutural e fomentam a educação antirracista.

Comumente nos deparamos com atos racistas no cotidiano ou com fatos veiculados pelas mídias a esse respeito. Conforme afirma a filósofa Djamila Ribeiro (2017), o 
racismo pode ser entendido como um "sistema de opressão que nega direitos, e não um simples ato da vontade do indivíduo", por isso a necessidade de trabalhar e entender o racismo em prol de transformar a sociedade brasileira em uma nação antirracista, ou seja, não apenas que não pratique o racismo, mas que combata sua prática, algo tão necessário hoje.

No Brasil, o sistema hegemônico de poder lida com os assuntos relacionados à população negra de forma resolvida ou romantizada pelo mito da democracia racial. Muitas vezes, as práticas sistemáticas racistas são reforçadas e enfatizadas, por exemplo, nos livros didáticos e recortes com tratamento da naturalização da miscigenação do período colonial, esvaziado de uma crítica a esse contexto histórico. Essa forma hegemônica de reprodução das narrativas raciais, geralmente, cria uma falsa harmonia racial no Brasil. Quando ela é confrontada com pesquisas e dados sobre o mapa racial brasileiro, os indicadores sociais e econômicos mostram que a situação do negro no país é o oposto do que tentam afirmar: que a situação do negro no Brasil não é inferior à do branco (ANJOS, 2005).

Reforçando o entendimento do racismo no Brasil, Munanga (2009) afirma que o racismo brasileiro se diferencia de outras partes do globo pelo fato de não ser explícito em todo o território nacional, mas silencioso. Sendo assim, é preciso romper com o silêncio estabelecido, com a harmonia que não existe, com o mito da democracia racial e com a redução do ser negro a determinados estereótipos.

Ribeiro (2017) diz que o silêncio é cúmplice da violência, por isso negros e brancos precisam se incomodar com a estrutura racista. É preciso questionar as pequenas questões vivenciadas no cotidiano que põem o negro como um ser reduzido na sociedade; é preciso enxergar o ser negro em toda a sua complexidade; é preciso entender que o racismo está em constante manutenção na sociedade, acompanhando todas as modificações que ocorrem nas relações sociais. Sobre esse assunto, o advogado, filósofo e professor Silvio Luiz de Almeida aponta que:

O racismo é parte da estrutura social e, portanto, não necessita de intenção para se manifestar, por mais que calar-se diante do racismo não faça do indivíduo moral e/ou juridicamente culpado ou responsável, certamente o silêncio o torna ética e politicamente responsável pela manutenção do racismo. (ALMEIDA, 2019, p. 34).

O autor ainda ressalta que, para mudar a sociedade, não basta apenas repudiar o racismo ou denunciar uma prática racista, mas "depende, antes de tudo, da tomada de postura e adoção de práticas antirracistas” (ALMEIDA, 2019, p. 32).

Sendo assim, engana-se quem pensa que o racismo é um assunto que deva ser discutido apenas pela população negra. Ele deve estar em pauta, principalmente, nas discussões daqueles que o praticam e o perpetuam na sociedade. Pensar que o fato de ter um amigo negro ou trabalhar com um preto isenta o indivíduo de ser racista é uma falácia. Tais afirmações só ajudam a fortalecer o racismo velado que existe na nossa sociedade, ampliando e fortalecendo as brincadeiras e piadas de cunho racista que estão presentes em nosso cotidiano.

Romper com a cultura do silêncio racial é se incomodar com o que está estabelecido, estranhar o comum e se indagar por que há tão poucos negros nas esferas de poder, na medicina, no corpo docente das universidades, chefes ou gerentes de empresas, já que no Brasil mais da metade da população é negra. Outra forma que pode contribuir para o 
rompimento desse silêncio é trabalhar nas discussões escolares indicadores que mostrem a situação da população negra, abordar questões como racismo recreativo e ressaltar a importância dessa população no processo da formação sociocultural do país.

\section{Educação Quilombola e implicações raciais}

Ao realizar-se uma análise histórica acerca das políticas educacionais brasileiras, percebe-se que ao negro sempre foi negado o direito de estudar. Por exemplo, a primeira lei referente à educação no Brasil, de 1837, afirmava a proibição dos escravizados e dos negros africanos, mesmo livres ou libertos, de estudarem. Essa proibição perdurou por um longo tempo, mesmo com o Decreto de $\mathrm{n}^{\circ}$ 7.031-A, de 6 de setembro de 1878, que autorizava o ensino da população negra no período noturno. Sabe-se que, mesmo com esse decreto, diversas manobras foram criadas para impedir o acesso à educação da população negra no Brasil.

As discussões acerca dessa temática se prolongaram durante anos no país, tendo maior visibilidade nos anos 1930, com a Frente Negra Brasileira, que lutou contra a estrutura racista vigente, levantando questionamentos quanto ao racismo e indagando o porquê da ausência dessa população em determinados cargos e posições na sociedade. Esses questionamentos foram aprimorados nos anos seguintes, tendo seu apogeu na institucionalização do Movimento Negro nos anos 1970 e 1980.

A Constituição de 1988, que assegura os direitos e deveres da população brasileira, afirma que a educação é um direito para todos os brasileiros do território nacional. O governo federal também garante saúde, cultura e educação aos descendentes quilombolas, por isso, nesse sentido, criou o programa Educação Escolar Quilombola, que tem como objetivo garantir a cultura e história da população quilombola do Brasil. Para isso, foi necessário criar diretrizes curriculares visando atender às especificidades dos alunos quilombolas.

Ainda nessa temática, vale ressaltar a Lei no $10.639^{1}$, de 9 de janeiro de 2003 (Brasil, 2003a), que alterou a Lei no 9.394/1996, tornando obrigatório o ensino da História e Cultura Afro-Brasileira nos estabelecimentos de Ensino Fundamental e Médio, oficiais e particulares. Essa lei representou uma forma de combater o racismo no Brasil pela educação, já que a escola é também um lugar de reprodução do racismo estrutural. Para fortalecer a luta da população negra brasileira, foi criado o Programa Brasil Quilombola, em 12 de março de 2004, que deu origem à Agenda Social Quilombola, por meio do Decreto $\mathrm{n}^{\circ} 6.261$, de 20 de novembro de $2007^{2}$, que possibilitou levantar questões quanto à educação e ao acesso à terra para os remanescentes de quilombos.

Visando avançar nas políticas e programas quilombolas, no ano de 2012 o MEC homologou a Resolução n 8/2012, que definiu as DCNEEQ. Essa conquista foi de muita importância, pois essas diretrizes possibilitaram o direcionamento da uma educação para os remanescentes de quilombos, para pensar nas questões culturais da comunidade e valorizá-las, considerando as especificidades do processo de ensino e aprendizagem da população quilombola.

1 Altera a Lei no 9.394, de 20 de dezembro de 1996, que estabelece as diretrizes e bases da educação nacional, para incluir no currículo oficial da rede de ensino a obrigatoriedade da temática "História e Cultura Afro-Brasileira", e dá outras providências (BRASIL, 2003).

2 Dispõe sobre a gestão integrada para o desenvolvimento da Agenda Social Quilombola no âmbito do Programa Brasil Quilombola, e dá outras providências (BRASIL, 2007). 
Sabe-se que, mesmo com todas essas conquistas, trabalhar as questões raciais na educação quilombola ainda é um desafio, pois, em diversos momentos, percebe-se pelos discursos da mídia ou até mesmo do setor político que esse assunto não é prioridade sem contar os atuais episódios ocorridos em órgãos públicos que tratam dessas questões no país, além dos investimentos que nem sempre chegam à ponta do processo, que são os alunos quilombolas. Para adicionar um agravante maior, o Estado extinguiu a Secretaria de Políticas de Promoção da Igualdade Racial (SEPPIR) ${ }^{3}$.

Os ataques começaram quando, no final do ano de 2018, o atual representante de Estado pensou na possibilidade de extinguir a SEPPIR, ocasionando diversos protestos e questionamentos acerca dessa decisão. Atualmente, a SEPPIR está inserida na pasta do Ministério da Mulher, da Família e dos Direitos Humanos. Com essa medida, percebe-se que, hoje, trabalhar as questões étnico-raciais no país se torna mais difícil com o atual governo, que lida com descaso quanto às políticas afirmativas.

Os episódios contra as instituições responsáveis pelas questões étnico-raciais se prolongaram. No ano seguinte, o Instituto Nacional de Colonização e Reforma Agrária (INCRA $)^{4}$, responsável pela delimitação e titulação das terras dos remanescentes de quilombos, ficou suspenso por alguns dias. Sem uma resposta clara sobre o ocorrido, a instituição retornou às atividades, mas há diversas reclamações quanto à atuação na titulação das terras pelas comunidades.

Esses acontecimentos vão ao encontro do apontamento de Silvio Luiz de Almeida (2019), no livro Racismo Estrutural, que afirma que o racismo se integra nas organizações econômicas, políticas e da sociedade. Quando o atual presidente da Fundação Cultural Palmares $(\mathrm{FCP})^{5}$ ataca diversos líderes de representatividade negra do país e tem um discurso que põe em questionamento as lutas dos povos negros no Brasil, ele reforça como é precisa a afirmação de Almeida (2019), levando-nos a perceber que o mito da democracia racial afeta toda a população, mesmo que de forma diferente, ou seja, alcança todos os indivíduos, independentemente do pertencimento étnico-racial. Uma forma de combater esse mito é trabalhar questões relacionadas aos negros no processo de ensino e aprendizagem, apresentando aos alunos as disparidades sociais e econômicas existentes no país quanto a essa população e proporcionar um currículo que resgate a história e a cultura afro-brasileira e africana, como se propõe a Escola Felizarda Maria Conceição de Azevedo.

\footnotetext{
${ }^{3}$ Fundada em 21 de março de 2003, a secretaria nasceu do reconhecimento das lutas históricas do Movimento Negro brasileiro. A data é emblemática, pois, em todo o mundo, celebra-se o Dia Internacional pela Eliminação da Discriminação Racial, instituído pela Organização das Nações Unidas (ONU), em memória do massacre de Sharpeville (BRASIL, 2003b).

${ }^{4}$ Por força do Decreto $n^{\circ}$ 4.887/2003, o INCRA é a autarquia competente, na esfera federal, pela titulação dos territórios quilombolas. As terras ocupadas por remanescentes das comunidades dos quilombos são aquelas utilizadas para a garantia de sua reprodução física, social, econômica e cultural. Como parte de uma reparação histórica, a política de regularização fundiária de territórios quilombolas é de suma importância para a dignidade e garantia da continuidade desses grupos étnicos (INCRA, 2020).

${ }^{5}$ No dia 22 de agosto de 1988, o governo federal fundou a primeira instituição pública voltada para promoção e preservação dos valores culturais, históricos, sociais e econômicos decorrentes da influência negra na formação da sociedade brasileira: a Fundação Cultural Palmares (FCP), entidade vinculada ao Ministério da Cidadania. Ao longo dos anos, a FCP tem trabalhado para promover uma política cultural igualitária e inclusiva, que contribua para a valorização da história e das manifestações culturais e artísticas negras brasileiras como patrimônios nacionais (BRASIL, 2017).
} 


\section{A Escola Quilombola Felizarda Maria Conceição de Azevedo em Quissamã}

O que distingue uma escola quilombola das demais é o fato de ela receber recursos do Programa Brasil Quilombola, do governo federal. Geralmente, está situada em territórios quilombolas ou em zonas rurais e oferta os conteúdos regulares, ou seja, conteúdos aplicados em todas as escolas do território brasileiro, porém destaca-se por um maior aprofundamento das questões raciais, da identidade negra e da interação entre a cultura e a história brasileira e africana.

A presente pesquisa sobre a educação quilombola foi realizada na Escola Municipal Felizarda Maria Conceição de Azevedo, inaugurada no dia 16 de maio de 2008, que se encontra situada na Estrada Principal Fazenda Machadinha, Bairro Fazenda Machadinha, Quissamã-RJ. A unidade oferta a Educação Infantil e o Ensino Fundamental I em período integral. O nome recebido por ela é em homenagem a Felizarda Maria Conceição de Azevedo, nascida em 19 de abril de 1884, filha da escrava Maria Januária da Conceição e do Visconde de Ururaí, Manuel Carneiro da Silva, senhor do Solar de Machadinha e genro do Duque de Caxias (MACHADO, 2006). Conhecida por muitos da cidade Quissamã, ela, sempre que solicitada por pesquisadores para conhecer a história local, estava disponível para contar suas experiências. Seu filho, Mário Azevedo, e algumas outras iniciativas culturais em Quissamã procuram resgatar e manter sua memória.

Em uma conversa com o diretor da instituição, foi possível perceber os desafios existentes em uma escola quilombola. O diretor afirmou que, de todos os problemas enfrentados, o obstáculo inicial foi inserir nas atividades escolares elementos que aproximassem a cultura afro-brasileira da comunidade. Relatou ainda como foi desafiador trabalhar com os docentes a importância de se elaborar atividades que abordassem elementos pertencentes aos ancestrais e também que levassem à formação cultural da comunidade Machadinha.

Segundo o diretor Daniel ${ }^{6}$, a direção, buscando solucionar essa situação, passou a desenvolver com os professores atividades relacionadas às questões étnico-raciais, como palestras, encontros e estudos sobre a Machadinha. A instituição passou a desenvolver projetos anuais que resgatassem a identidade negra presente na comunidade e, em 2019, criou uma série de encontros pedagógicos quinzenais para discutir um projeto político-pedagógico (PPP) que atendesse às Diretrizes Curriculares Quilombolas.

A escola conta com a participação de representantes da comunidade para relatar como é a realidade da Machadinha e busca atender às políticas estabelecidas no CNE de 2012 sobre as questões quilombolas, fazendo com que o PPP atinja todos os elementos exigidos pelas DCNEEQ.

Dessas atividades desenvolvidas na escola estão: Projeto Pequeno Griôs; Poesia em Ação (os alunos vão até a senzala recitar poemas); Dia de Celebrar as Conquistas (relacionado ao dia 13 de maio); dramatização valorizando a culinária local, representada pelos alunos da Educação Infantil; construção de maquetes com personagens negros; dança valorizando o jongo; e outras atividades artísticas e teatrais.

Dos treze professores da Escola Municipal Felizarda Maria Conceição de Azevedo, $69,23 \%$ trabalhavam nas atividades pedagógicas sobre a ancestralidade afro-brasileira, objetivando aproximar o aluno de sua história e da comunidade Machadinha. Segundo

\footnotetext{
${ }^{6} \mathrm{O}$ nome do diretor foi trocado para um fictício para preservar a identidade do entrevistado.
} 
os relatos docentes, houve um desafio para abordar a temática "étnico-racial" na prática pedagógica, pois alguns deles não tiveram uma formação nessa área em seus estudos. Este fato vai ao encontro do pensamento de Munanga (2005, p. 15), que afirma que muitos professores brasileiros "[...] não receberam [...] o necessário preparo para lidar com o desafio [da] problemática da convivência com a diversidade e as manifestações de discriminação dela resultadas".

É importante abordar a temática "educação das relações étnico-raciais" em todas as etapas de ensino, pois é preciso se colocar constantemente contra o racismo que perdura por séculos na sociedade brasileira e que está estruturado na educação. É necessário ressaltar as questões raciais na educação em todas as esferas, a começar pelos materiais didáticos, que, em sua maioria, retratam apenas o sofrimento da população negra, esquecendo sua importância para a formação sociocultural do Brasil. Sobre essas questões, Anjos (2005) pondera que a educação é ponto norteador e que por meio dela é possível modificar o quadro de atraso que há nos brasileiros no que diz respeito ao "[...] lugar insignificante a que os contextos afro-brasileiros têm sido relegados em quase todos os sistemas e níveis de ensino" (2005, p. 176). Do mesmo modo, pode-se evidenciar nas palavras do professor universitário, político e ativista dos direitos civis e humanos das populações negras, Abdias do Nascimento, que:

O sistema educacional [brasileiro] é usado como aparelhamento de controle nesta estrutura de discriminação cultural. Em todos os níveis do ensino brasileiro - elementar, secundário, universitário - o elenco das matérias ensinadas [...] constitui um ritual da formalidade e da ostentação da Europa. [...] Se consciência é memória e futuro, onde está a memória africana, parte inalienável da consciência brasileira? Onde e quando a história da África, o desenvolvimento de suas culturas e civilizações, as características do seu povo, foram ou são ensinadas nas escolas brasileiras? Quando há alguma referência ao africano ou negro, é no sentido do afastamento e da alienação da identidade negra. Tampouco na universidade brasileira o mundo negro-africano tem acesso. (NASCIMENTO, 1978 apud SANTOS, 2005, p. 23).

A ausência de pessoas negras na esfera de poder do ensino causa para o aluno negro uma série de consequências negativas, já que a todo instante sua identidade é negada ou ignorada enquanto tema insurgente do currículo que se estende da Educação Básica ao Ensino Superior. Sobre a presença do negro no currículo, Cavalleiro (2005) destaca a falta de representatividade nos materiais escolares, e isso contribui para a permanência do racismo estrutural.

Enfim, a Escola Municipal Felizarda Maria Conceição de Azevedo, diante de todas essas questões e do atual cenário, procura resgatar a identidade quilombola e as tradições da comunidade Machadinha. A instituição busca, em suas atividades e projetos anuais, reconhecer as práticas culturais locais da comunidade Machadinha e levar aos jovens remanescentes discussões acerca das questões raciais e da história de seus ancestrais, as quais são importantes para manter a representatividade da cultura quilombola em seu território.

Acreditamos que a escola é um lugar de direito com possibilidade para resgatar a cultura afro-brasileira e a história africana e, assim, promover o reconhecimento do negro, pois, durante muito tempo, a sua existência enquanto sujeito de direito ficou no silenciamento - e direito aqui evoca pensar não somente na escola e seu currículo, mas também no lugar de morar na cidade, como mostra a seção seguinte. 


\section{Bairros Negros no contexto histórico-racial de Itaperuna}

A memória é um dispositivo cognitivo e social que faz lembrar as formas de existir e de significar os objetos e equipamentos de diferentes tempos e espaços da cidade. Em seu romance As Cidade Invisiveis, Ítalo Calvino diz que: "A memória é redundante: repete os símbolos para que a cidade comece a existir" (CALVINO, 1990, p. 23). De fato, a existência de uma cidade se dá pela memória visual, e o seu espaço urbano é visto pelo olhar de quem se coloca a dizer sobre ela a respeito de suas projeções pretéritas e futuras. Definimos aqui o espaço urbano como o espaço da cidade, com ruas, bairros, praças e diferentes tipos de equipamentos, como fábricas, bancos, igrejas, casas, e com estrutura social própria do sistema urbano (CASTELLS, 2020, p. 340).

Sobre o tipo de cidade, Corrêa (1989) diz que o espaço urbano de uma cidade capitalista é simultaneamente fragmentado e articulado, e toda cidade como forma do espaço urbano está dividida em áreas residenciais segregadas, o que faz refletir da sua paisagem uma complexa estrutura social de diferentes classes sociais. Já em um recorte mais específico do espaço urbano, para Cunha Júnior (2019) “[...] a cidade é composta de bairros onde vivem as pessoas e onde a diversidade humana se manifesta". O autor afirma também que: "Existe uma intencionalidade em não tratar as temáticas de interesse da população negra e as raízes dessa problemática precisam ser pensadas e discutidas" (CUNHA JÚNIOR, 2019 , p. 19). Para esse autor, é fundamental que, ao estudar o campo do conhecimento urbanístico, haja uma preocupação de se centralizar na importância da produção da cidade, principalmente para as habitações que representam um tipo de indicador de desigualdade social e têm consequências visíveis para a vida da população negra, o que é chamado por ele de racismo antinegro. Ele o define assim:

O racismo antinegro como ideologia é estrutural na formação histórica brasileira, pode ser lido na história da realidade, constatado na geografia e na forma urbana das cidades brasileiras e deveria ser um conceito de análise nas diversas ciências humanas brasileiras, no entanto ocorre o contrário, o contraditório, racismo estrutural antinegro é conceito rejeitado por boa parte das ciências humanas sob a fraca alegação de que devido à "miscigenação racial" não existe racismo nas relações sociais brasileiras. (CUNHA JÚNIOR, 2019, p. 16).

Contra a permanência do racismo estrutural antinegro posto pelo autor, Mota (2009) diz que a questão racial no Brasil sempre foi tema de consenso e controvérsia. Isso está na idealização e na condução da elite dirigente do Estado, pois, em suas instâncias do poder, a sua maioria são homens e mulheres brancas que sempre utilizaram os mecanismos de controle e os discursos institucionais e que, de seus lugares de poder, como a universidade, a escola e a mídia, "[...] promoveram simbolicamente a integração nacional sob o 'conto das três raças', em que, brancos, negros e índios forjaram a identidade nacional do Brasil mestiço e homogêneo racialmente" (MOTA, 2009, p. 15).

Nesse mesmo sentido, sobre esse lugar de poder de homens e mulheres hegemonicamente brancos autorizados como únicos produtores do conhecimento científico e de narrativas sobre a cidade e o seu espaço urbano, Cunha Júnior (2019) diz haver a invisibilização da população negra no pensamento urbanístico, porque isso tem a ver com a sua não inserção no espaço urbano. Segundo esse autor, ainda é recorrente, ao tratar da segregação do espaço urbano, condenar "apenas o mercado imobiliário, sendo acrítico sobre as responsabilidades das instituições públicas e das universidades” em relação ao tema, 
por se afugentarem da discussão do racismo estrutural - pauta esta ainda cara para o Brasil (Cunha Júnior, 2019, p. 17). O autor diz que trazer o racismo como questão para pensar no urbano é um grande esforço intelectual, pois isso requer romper com o estado de invisibilidade que recai na população negra sob o peso da raça - raça aqui não no sentido biológico, porque não existe, mas como poder de estratificação social pela qual se reproduz estruturalmente a pecha do lugar invisível do negro sobre o seu passado histórico no espaço urbano.

Resgatar a produção dos bairros negros e periféricos de Itaperuna exige se debruçar sobre a sua paisagem e identificar os diferentes processos históricos que marcaram o espaço urbano iniciado no período colonial, como em tantas outras cidades brasileiras. O que define o bairro negro é o seu tempo-espaço de concentração populacional de maioria negra e de histórico de ancestralidade afrodescendente.

Itaperuna, como lugar de passagem entre Rio de Janeiro e as províncias de Minas Gerais, desde o início se despontou com uma economia agrária que se destacava no Norte Fluminense. O curso do rio Muriaé servia para marcar a rota de diferentes tropeiros, que se aventuravam em meio à mata virgem densa para povoar as terras e transportar mercadorias, entre as quais o escravizado africano reconhecido como não humano pelo sistema colonial.

No ano de 1834, o então colonizador José de Lannes Dantas Brandão fixou residência na região, onde demarcou o território da fazenda batizada como Porto Alegre, a qual possuía grande dimensão territorial. As dependências dela contavam com boa infraestrutura, comum a uma casa-grande do seu tempo. Porém, no mesmo ano, ele vendeu a propriedade ao sr. Abreu de Lima.

Documentos comprovam que o marco inicial de Itaperuna é a fazenda Porto Alegre. No decorrer do tempo, ela passou por diversos proprietários, até que, com a morte de seu último dono, o sr. Ábido Bussade, que veio a falecer em 1972, e depois de alguns anos sem função, as dependências foram refuncionalizadas para a casa de repouso para deficientes mentais (PIRES et al., 2005, p. 71).

Como toda casa-grande de uma produção colonial, a fazenda Porto Alegre possuía grande extensão de terras, com variação da cultura de subsistência e plantação.

A localização geográfica do sítio do entorno da fazenda Porto Alegre contribuiu para a rápida expansão urbana, e a vila foi elevada à categoria de cidade em 06 de dezembro de 1889, por meio Lei $n^{\circ} 2.921$, e recebeu o nome de Itaperuna, que, em Tupi- Guarani, significa "Caminho da Pedra Preta". Itaperuna em 6 de dezembro de 1889, quando deixou de ser vila e recebeu o título de cidade, contava sob sua jurisdição os seguintes distritos: São José do Avaí (Itaperuna), Nossa Senhora da Penha (Aré), Laje do Muriaé, São Sebastião da Boa Vista, Natividade do Carangola, Santo Antônio de Carangola (Porciúncula), Varre-Sai, Santa Clara de Carangola, Arrozal de Sant'Ana do Itabapoana (Rosal), Bom Jesus do Itabapoana, Santo Antônio do Itabapoana (Calheiros) e Santa Rita do Ouro Fino (DINIZ, 1985).

Com a abolição e o advento da República, consequentemente ocorreu o desenvolvimento urbano da cidade de Itaperuna, e a fazenda, que estava no centro do processo de expansão do seu entorno, passou para a especulação imobiliária. Desde então, muitos empreendimentos de capital privado foram construídos no entorno da antiga fazenda Porto Alegre. Atualmente, onde antes funcionava a sede da fazenda, encontram-se o clube $\mathrm{AABB}$, algumas residências particulares e comércios. Já onde eram as dependências da 
fazenda, como os terreiros para secar grãos, encontra-se a casa de festa "Espaço Lounge". Da paisagem antiga, o local preserva algumas palmeiras-imperiais e uma figueira-branca, cujo diâmetro mostra a resistência ao tempo físico e histórico - essa árvore é uma característica dos lugares onde os escravizados utilizavam como lugar de atividades laborais.

\section{Apontamentos para pensar no racismo em bairros periféricos de Itaperuna}

Estudar os bairros negros da cidade de Itaperuna impõe um desafio ao pesquisador, pois são praticamente inexistentes as fontes disponíveis. De acordo com Souza e Cunha Junior (2019), até então não houve esforço local para a preservação dos dados e tampouco pesquisas a esse respeito sobre a participação do negro na região de Natividade, que, anteriormente, pertencia ao município de Itaperuna.

Itaperuna cresceu seguindo às margens do rio Muriaé e serviu de orientação para os primeiros habitantes que chegavam e fixavam suas residências no entorno das suas margens. Quem tinha um poder aquisitivo melhor estabelecia residência mais perto do rio, buscando um melhor conforto; já os mais pobres ocupavam os lugares mais afastados. Essa dinâmica inicial pela ocupação do espaço urbano já mostra a sua segregação (SOUZA, 2018, p. 59). A elite local é o agente transformador e também segregador do espaço urbano da cidade de Itaperuna. Diferentemente dos pobres e da população negra deixada à margem da República pós-abolição, ela, na sua maioria, é detentora de posse e uso da terra e também que possui, primeiramente, acesso a bens e serviços dos quais a população pobre e negra não dispõe. Assim, a elite local é determinante na segregação econômica, porque os seus agentes são os detentores do meio de produção e os responsáveis pela reprodução do racismo estrutural, por ocuparem também os setores institucionais. São eles os (re)produtores dos discursos aceitos como únicos e legítimos, na manutenção do status quo das políticas sociais de habitação, saúde, educação e de assistência social e lazer.

Por outro lado, a cidade se desenvolveu graças às suas terras férteis, e seu relevo e sua hidrografia foram propícios para a cultura agrária, o que por muito tempo, durante $\mathrm{o}$ século XX, fez do Noroeste Fluminense uma região produtora de café.

Nesse contexto histórico e econômico, sabe-se que o crescimento de Itaperuna não foi planejado. Como muitas outras cidade no Brasil, ela cresceu atendendo às necessidades e demandas de bens e serviços dos grupos privilegiados e seguindo as regras postas pelo mercado imobiliário e pelas políticas de Estado, em detrimento dos grupos que historicamente sempre estiveram fora do lugar nas deliberações do espaço urbano (os pretos e pardos). É fato que os primeiros bairros na cidade se expandiram e se multiplicaram, gerando outros territórios, porém a divisão socioespacial-racial continua sendo o maior vetor de segregação.

A criação de cada um dos bairros itaperunenses remonta a história do começo da organização espacial da cidade, o que, para a sua compreensão, requer fazer um recorte de tempo-espaço e explicar as delimitações socioespaciais - atualmente, é possível ver os bairros com infraestrutura e valorização mobiliária elevada e os bairros com pouca infraestrutura e baixo valor mobiliário, chamados de periferia.

A saber, o bairro Centro teve início com a chegada dos colonizadores por volta de 1831 até aproximadamente 1881, quando ainda era Vila São José do Avaí. De acordo 
com Diniz (1985, p. 32), “A Vila São José do Avaí, pelas Leis provinciais no 2.810, de 24 de novembro de 1885, e 2.921, de 29 de dezembro de 1889, foi elevada à categoria de Município com a cidade Itaperuna". Herança da estrutura colonial racista, a expansão urbana de Itaperuna nasceu segregacionista, com aqueles que ficaram dentro e com os que ficaram fora. Próximo à linha férrea habitava a elite branca, e nos locais mais altos, nos morros, as pessoas pobres e negras - ainda hoje elas são encontradas nos mesmos lugares. Com o passar dos anos, o aumento populacional fez com que a zona central da cidade crescesse e se desmembrasse em novos bairros, como Morro do Castelo, Marca Tempo, Horto Florestal, Morro do Cristo e Bico da Foice. São bairros que foram agregando moradias com "ideias fora do lugar", porque esses lugares, segundo Cunha Júnior (2019, p. 21-22), “[...] não fazem parte do conhecimento universitário, em virtude da forma de construir não obedecer ao pretendido pelas formalidades teóricas, portanto desconsiderado e transformado em ilegal".

No caso do bairro Niterói, ele surgiu da demanda para alocar as famílias que chegavam ao município em busca de trabalho. Com o fim do período escravocrata e os libertos abandonados à própria sorte pelos seus ex-senhores, a migração para a cidade era a única certeza de novos horizontes. A perspectiva por novas oportunidades de trabalho era sua nova realidade. Pobres e pretos eram maioria na década de 1890 e migraram das fazendas da zona rural para a cidade, assumindo atividades econômicas, tais como: açougueiros, sapateiros, ferreiros, entre outros ofícios considerados autônomos. Portanto, o crescimento da cidade contou com a mão de obra do negro em diversos segmentos de serviços.

Hoje, a existência de muitos bairros negros em Itaperuna, como Morro do Castelo, Marca Tempo, Horto Florestal, Morro do Cristo e Bico da Foice - já citados anteriormente -, compostos, em sua maioria, por população preta e parda e com infraestrutura inferior aos bairros de classe média e média alta, nos quais a maioria da população é branca, demonstra uma definição racial de estratificação social de que esses bairros são ocupados e experenciados somente pela população negra. Negro aqui é raça, e raça é consciência do lugar de estratificação social que o negro ocupa por causa do racismo estrutural. Posto isso, para finalizar, é importante investigar, analisar e comparar a condição social vivida hoje pela população negra de Itaperuna. Portanto, essa é uma discussão que não se encerra neste breve trabalho, já que o tema "Bairros Negros de Itaperuna" faz parte de uma pesquisa que está em curso.

\section{Conclusão}

O presente texto abordou a implementação da Educação Escolar Quilombola na Escola Municipal Felizarda Maria Conceição de Azevedo, situada no território quilombola da comunidade Machadinha, no município de Quissamã, pertencente à região norte do estado do Rio de Janeiro. Buscou também entender os desafios e as possibilidades da prática e discurso docentes para se implementar um currículo com forma e conteúdo para a educação quilombola, considerando que a forma exige mudança de postura e pensamento para o combate ao racismo, conforme preconiza a Lei ${ }^{\circ} 10.639 / 2003$, e o conteúdo deve resgatar a cultural afro-brasileira e a história africana, o que envolve a prática pedagógica, bem como a ancestralidade dos quilombolas da Machadinha. 
Aqui ainda foi apresentado o contexto histórico-racial forjado na produção escravista, sendo a fazenda Porto Alegre o lugar onde o negro era desumanizado e escravizado pelo regime escravocrata. Foi a fazenda também o início do processo de urbanização da cidade de Itaperuna, o que fez com que o contingente escravizado deixasse de ocupar a senzala para ocupar as áreas distantes - hoje, a periferia da cidade, denominada bairros negros. O surgimento desses bairros negros em Itaperuna foi herança do racismo estrutural colonial, que passou a ser o lugar de morar do negro. Se, no primeiro momento, o negro era esvaziado da sua humanidade, agora, livre e homem, já na República, foi abandonado a um estado de invisibilidade, e, já se distanciando da casa-grande (fazenda Porto Alegre), o morro tornou o seu lugar de alcance. Nesse lugar ainda hoje se encontram os bairros negros de Itaperuna, os quais, quando comparados com os bairros de maioria branca, possuem menos infraestrutura e serviço público, como saúde, educação, assistência social e lazer.

Conclui-se que as temáticas apresentadas - o caso da Escola Municipal Felizarda Maria Conceição de Azevedo, que tratou das práticas e discursos docentes sobre a educação quilombola na escola em Quissamã, e o caso do resgate dos bairros negros de Itaperuna, que tem a origem histórica no escravização de africanos e afrodescendentes - têm em comum o objetivo de resgatar o tempo e o espaço, o passado e o presente do negro como sujeito da sua história e agente transformador do espaço social urbano. Nesse sentido, o resgate histórico da educação quilombola em Quissamã, na Machadinha, é uma possibilidade de ruptura com o silenciamento do estado de invisibilidade do negro na produção do conhecimento no contexto da educação brasileira, no campo do currículo, que, durante séculos, manteve a cultura afro-brasileira e a história africana interpretada por uma visão unicamente eurocentrista. Já quanto ao resgate dos bairros negros em Itaperuna, a proposta representa uma possibilidade de recontar a história da expansão urbana não mais por meio de uma visão branca, que por muito tempo silenciou a diferença entre pretos e brancos sob o mito da democracia racial. De fato, visto sob uma visão crítica, como aponta Nascimento (1978 apud SANTOS, 2005, p. 23), o sistema educacional é usado como aparelhamento de controle de discriminação da cultura afro-brasileira, sendo ainda hoje desafiador ao negro ocupar o seu lugar no currículo escolar e na universidade brasileira. Para Almeida (2019, p. 34), a diferença entre negro e branco se deve ao racismo estrutural antinegro. Para concluir, Cunha Júnior (2019) afirma que resgatar os bairros negros como tema de pesquisa é trazer para o debate o lugar do negro lugar até então fora das ideias urbanísticas, ou seja, do pensamento urbano enquanto campo das ciências humanas.

\section{REFERÊNCIAS}

ALMEIDA, S. L. Racismo estrutural. São Paulo: Pólen, 2019.

ANJOS, R. S. A. A África, a Educação Brasileira e a Geografia. In: BRASIL. Ministério da Educação. Secretaria de Educação Continuada, Alfabetização e Diversidade - SECAD. Educação anti-racista: caminhos abertos pela Lei Federal no 10.639/03. Brasília: Ministério da Educação, Secretaria de Educação Continuada, Alfabetização e Diversidade, 2005. (Coleção Educação para todos).

BOURDIEU, P. F. Razões práticas: sobre a teoria da ação. Campinas: Papirus, 1996.

BRASIL. Decreto de $n^{\circ}$ 6.261, de 20 de novembro de 2007. Dispõe sobre a gestão integrada para o desenvolvimento da Agenda Social Quilombola no âmbito do Programa Brasil Quilombola, e dá outras 
providências. Diário Oficial da República Federativa do Brasil, Brasília, DF, 2007. Disponível em: <http://www.planalto.gov.br/ccivil_03/_ato2007-2010/2007/decreto/d6261.htm>. Acesso em: 18 ago. 2020.

BRASIL. Resolução nº 8, de 20 de novembro de 2012. Define Diretrizes Curriculares Nacionais para a Educação Escolar Quilombola na Educação Básica. Diário Oficial da República Federativa do Brasil, Brasília, DF, 2012. Disponível em: $<$ http://portal.mec.gov.br/index.php?option=com_docman\&view=download\&alias=11963rceb008-12-pdf\&category_slug=novembro-2012-pdf\&Itemid=30192>. Acesso em: 27 ago. 2020.

BRASIL. Ministério da Justiça e Segurança Pública. Secretaria de Políticas de Promoção da Igualdade Racial - SEPPIR. Você conhece a SEPPIR. Brasília: Ministério da Justiça e Segurança Pública, 2017. Disponível em: <https://www.justica.gov.br/news/conheca-melhor-o-trabalho-da-seppir>. Acesso em: 18 ago. 2020.

CALVINO, Í. As cidades invisíveis. São Paulo: Companhia das Letras, 1990.

CASTELLS, M. A questão urbana. Rio de Janeiro: Paz \&Terra, 2020.

CAVALLEIRO, E. S. Introdução. In: BRASIL. Ministério da Educação. Secretaria de Educação Continuada, Alfabetização e Diversidade - SECAD. Educação anti-racista: caminhos abertos pela Lei Federal no 10.639/03. Brasília: Ministério da Educação, Secretaria de Educação Continuada, Alfabetização e Diversidade, 2005. (Coleção Educação para todos).

CORRÊA, R. L. O espaço urbano. São Paulo: Ática, 1989.

CUNHA JÚNIOR, H. Bairro negro, lugar fora das ideias urbanísticas. In: CUNHA JUNIOR, H. et al. (Org.). Bairros negros cidades negras. Fortaleza, CE: Editora Via Dourada, 2019.

DINIZ, D. O desenvolver de um município Itaperuna: do germinar à frutificação. Rio de Janeiro: Damadá, 1985.

INSTITUTO NACIONAL DE COLONIZAÇÃO E REFORMA AGRÁRIA - INCRA. Passo a passo titulação de territórios quilombolas. Brasília: INCRA, 2020. Disponível em: <http://www.incra.gov. br/pt/quilombolas.html>. Acesso em:18 ago. 2020.

MACHADO, F. S. Fazenda Machadinha: memória e tradições culturais em uma comunidade de descendentes de escravos. 2006. 116 f. Dissertação (Mestrado Profissional em Bens Culturais e Projetos Sociais)Fundação Getúlio Vargas, Rio de Janeiro, 2006.

MOTA, E. A. O olhar dos agentes escolares sobre a lei 10.639/03: o desafio de sua implementação. 2009. 149 f. Dissertação (Mestre em Políticas Sociais)-Universidade Estadual do Norte Fluminense Darcy Ribeiro, Campos dos Goytacazes, 2009.

MUNANGA, K. (Org.). Superando o racismo na escola. Brasília: MEC, 2005.

MUNANGA, K. Origens africanas do Brasil contemporâneo: história, línguas, culturas e civilizações. São Paulo: Globo, 2009.

PIRES, C. S. et al. Fazendas históricas. Itaperuna: Editora Damadá Artes Gráfica e Editora LITA, 2005.

RIBEIRO, D. O que é lugar de fala. Belo Horizonte: Letramento, 2017. (Coleção Feminismos Plurais).

SANTOS, S. A. A Lei no ${ }^{\circ}$ 10.639/03 como fruto da luta anti-racista do Movimento Negro. In: BRASIL. Ministério da Educação. Secretaria de Educação Continuada, Alfabetização e Diversidade. Educação anti-racista: caminhos abertos pela Lei Federal no 10.639/03. Brasília: MEC, Secretaria de Educação Continuada, Alfabetização e Diversidade, 2005. (Coleção Educação para todos).

SOUZA, M. A.; CUNHA JUNIOR, H. Bairros Negros e suas Formações na Cidade de Natividade-RJ. In: CUNHA JUNIOR, H. et al. (Org.). Bairros negros cidades negras. Fortaleza, CE: Editora Via Dourada, 2019.

SOUZA, M. L. Os conceitos fundamentais da pesquisa sócio-espacial. São Paulo: Bertrand Brasil, 2018. 
SOBRE OS AUTORES

Felício Alves de Azeredo - Azeredo, F. A. Mestrando em Geografia Universidade Federal Fluminense/Programa de Pós-Graduação em Geografia da UFF/CAMPOS. Grupo de pesquisa: NEPECGIM.

Marcia Aparecida Pereira de Mello. Profa. Escola Municipal Ary Parreiras Itaperuna - RJ. Mestrando em Geografia - Universidade Federal Fluminense/ Programa de Pós-Graduação em Geografia da UFF/CAMPOS. Grupo de pesquisa: NEPECGIM.

Edimilson Antônio Mota - Mota, E. A. Prof. da Licenciatura em Geografia e do PPG UFF Campos. Coordenador do Núcleo de Ensino e Pesquisa sobre Espaço e Currículo de Geografia e Imagem e Multiculturalismo - NEPECGIM. 


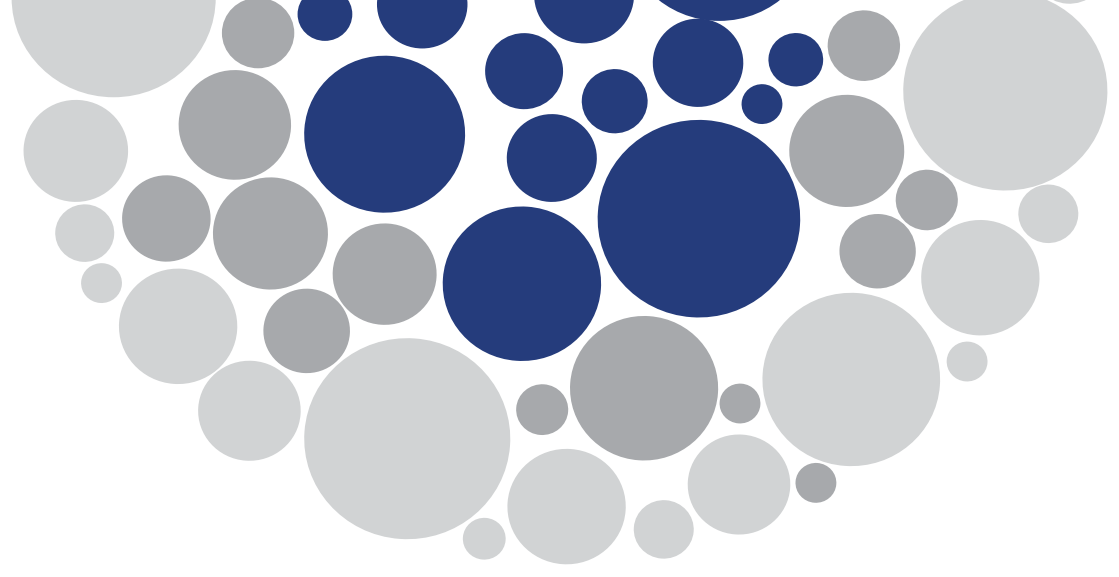

\title{
Vila da Terra: percepção após o reassentamento
}

\author{
Elaine C. R. Mendes Emerick ${ }^{a}$ Elzira Lúcia de Oliveira ${ }^{b}$ \\ a Mestranda do Programa de Mestrado em Geografia, Universidade Federal Fluminense (UFF), Campos dos Goytacazes \\ (RJ), Brasil. E-mail: elaine.emerick@gmail.com \\ • Departamento de Geografia de Campos, Universidade Federal Fluminense (UFF), Campos dos Goytacazes (RJ), Brasil. \\ E-mail: elziralucia@id.uff.br
}

\section{Introdução}

O reassentamento Vila da Terra foi construído para a realocação de famílias do $5^{\circ}$ distrito de São João da Barra, Rio de Janeiro, desapropriadas para a construção de um Distrito Industrial que compõe o Complexo Logístico Portuário, denominado Porto do Açu.

Esse reassentamento foi autorizado por meio do Decreto Estadual no $41.915 / 2009$, aprovado pela Câmara de Vereadores de São João da Barra, que permitiu a desapropriação por interesse público da área. O processo de desapropriação foi realizado pelo Governo do Estado do Rio de Janeiro, por meio da Companhia de Desenvolvimento Industrial do Estado do Rio de Janeiro (CODIN) e pela LLX, empresa de logística do Grupo EBX, posteriormente adquirida pelo grupo EIG e reestruturada atualmente como Prumo Logística (RIO DE JANEIRO, 2009).

Trata-se de uma área rural destinada, a princípio, para alocar 53 famílias consideradas elegíveis para o programa de reassentamento do empreendimento portuário. O local contou com a infraestrutura necessária para o assentamento das famílias, segundo os critérios recomendados pelo Banco Mundial. As residências foram construídas em terrenos com área mínima de 2 hectares, preparadas para o cultivo agrícola e pecuária, com solo tratado e adubado. Todas as moradias estavam equipadas com móveis e eletrodomésticos novos, além de estar em andamento um processo de formação de uma associação de moradores e produtores rurais (PORTO DO AÇU, 2017). 
O reassentamento Vila da Terra fica próximo à Rodovia BR-356, que permite fácil acesso à sede do município e a Campos dos Goytacazes, cidade de maior porte que fica perto das instalações do Porto do Açu.

O Complexo Logístico Industrial do Porto do Açu é um grande projeto industrial e de infraestrutura que produz, ao mesmo tempo, impactos positivos sobre o território e impactos negativos, especialmente, sobre os meios de vida da população diretamente impactada.

Projetos como esse também interferem na paisagem em que o ser humano já havia estabelecido suas relações e atendido às suas necessidades básicas, como moradia e subsistência. Assim, cada indivíduo desenvolve uma relação particular com o lugar, responde diferentemente diante das ações sobre o local e constrói seu julgamento com base nas experiências e expectativas próprias.

O objetivo deste trabalho é investigar a percepção das famílias sobre os impactos positivos e negativos do reassentamento a partir de vários aspectos da sua vida cotidiana. Em termos específicos, o trabalho analisa o perfil geral dos reassentados e as questões relacionadas ao uso e manejo da terra, comercialização da produção, geração de renda, relações sociais, infraestrutura da moradia, mobilidade urbana, localização geográfica e processo de negociação, em uma perspectiva comparativa da situação atual com a situação no local de origem.

A estrutura deste artigo está composta por uma fundamentação teórica com os antecedentes na literatura sobre impactos sociais causados por reassentamentos, seguida de um breve relato da área de estudo. Depois, são apresentados os materiais e métodos utilizados na pesquisa, a análise dos resultados e, por fim, as considerações finais.

\section{Antecedentes na literatura}

Segundo a definição da Organização das Nações Unidas (ONU), reassentamentos são oriundos de um deslocamento humano forçado, programados ou não planejados. São executados por órgãos públicos ou privados com base em diretrizes de organismos internacionais que atuam em defesa da justiça social e dos direitos humanos, normalmente vinculados à ONU. Os reassentados estão protegidos pelo direito à moradia, garantido pela Declaração Universal de Direitos Humanos (ORGANIZAÇÃO DAS NAÇÕES UNIDAS, 1948) e assegurado pelo artigo 6 da Constituição Federal de 1988 (BRASIL, 1988).

O deslocamento involuntário de uma comunidade torna-se relevante de ser estudado sob a ótica geográfica, pois pode impactar diretamente nas relações de um indivíduo com o espaço socialmente construído ou espaço geográfico e pode também estar edificado por diferentes escalas ou categorias, sendo que algumas delas são o território, a territorialidade, o espaço e o lugar.

O território pode ser visto sob três pontos, quais sejam: 1) como um bem jurídico-político, em que é delimitado e controlado, por meio do qual se exerce determinado poder; 2) como um bem cultural ou simbólico, sendo produto da apropriação/valorização simbólica de um grupo sobre o seu espaço; e c) como um bem econômico, na relação capital-trabalho (HAESBAERT, 2003).

O território toma então uma função de uso, aproveitamento e produção, não se restringindo ao território em si, mas entendido como um elemento de identidade, que, 
por sua vez, concebe o sentimento de pertencimento e existência. O território é a base para o trabalho, para a morada, para as trocas de saberes materiais, para o fortalecimento espiritual e para a prática de vida (SANTOS, 2006).

O território, portanto, é o que está próximo e o que conecta o ser humano ao espaço concreto, não restringindo sua dimensão, além de possuir um significado individual e social. Por isso, ele se estende até onde vai a territorialidade, a qual é aqui entendida como projeção da identidade sobre o território (MESQUITA, 1995, p. 83).

A territorialidade é complementar ao território e diz respeito à integração do indivíduo a um território quando se sente reconhecido nele, e esse sentimento produz o pertencimento a um território. A abordagem da territorialidade está direcionada ao indivíduo, em que ele é quem define a dimensão e a escala do seu espaço, suas relações, seu horizonte geográfico, suas necessidades de deslocamento e vivências. A territorialidade, nesse caso, amplifica-se nas experiências culturais, em que cada indivíduo deve ser visto, percebido e entendido (SPOSITO, 2004).

Já o espaço também é considerado lócus propulsor da produção, onde sem a produção não há lugar e sem lugar não há produção. O espaço é ainda totalizador, e cada dimensão é solidária ao todo. Nesse âmbito, a circulação, a repartição e o consumo são exercidos de forma integradora (SANTOS, 1985).

A vivência da desterritorialização e sua consecutiva reterritorialização, ou reinvenção do "novo lugar", também são explicadas por Saquet (2009, p. 216): "Na desterritorialização, perdem aspectos e elementos, relações, que tentam reproduzir no novo lugar em construção. Reterritorializam-se lentamente, reorganizando suas vidas diárias, cultural, política e economicamente no lugar", ou seja, trata-se de um processo lento de adaptação.

A luta pela terra tem mais notoriedade pela representação do Movimento dos Trabalhadores Rurais Sem Terra (MST) e do Movimento dos Atingidos por Barragens (MAB), em razão das proporções de deslocamento serem maiores. Ambos os casos estão associados aos processos de territorialização de indivíduos submetidos a um processo de desterritorialização e reterritorialização. Considerando o deslocamento provocado por empreendimento portuários, as comunidades deslocadas têm como futuro a reconquista do novo território e do seu modo de viver (MEDEIROS; LINDER, 2014).

$\mathrm{Na}$ ausência de legislação específica, os responsáveis por projetos de reassentamento valem-se, geralmente, das diretrizes estabelecidas pelo Banco Mundial - primeira instituição financeira internacional a desenvolver uma salvaguarda sobre reassentamento involuntário -, que depois serviram como modelo para outras instituições. Logo, a lacuna na legislação não é exclusividade do Brasil (FUNDAÇÃO RENOVA, 2018).

Os elementos mínimos da Política Operacional de Reassentamento são compostos por: levantamento censitário das pessoas deslocadas; avaliação dos bens; descrição de compensação e outras assistências ao reassentamento a serem fornecidas; consultas à população deslocada acerca de alternativas aceitáveis; responsabilidade institucional pela implementação; procedimentos para a apresentação e resolução de reclamações; acordos para monitoramento e implementação; cronograma e orçamento (CORPORAÇÃO FINANCEIRA INTERNACIONAL, 2012).

No plano internacional, destacam-se os trabalhos de Tan e Yao (2006) e Wilmsen, Webber e Duan (2011), que abordaram questões de reassentamentos resultantes da construção da Usina Hidrelétrica de Três Gargantas, na China. Esses autores examinaram os problemas ambientais críticos associados ao reassentamento do projeto, revelando o 
impacto ambiental resultante de uma contradição entre a área inundada e a demanda de terras para o reassentamento, mas também apresentaram ações de contramedidas positivas, como obras de engenharia para proteção de terras agrícolas, desenvolvimento de ecoagricultura e ajustes na política de reassentamento (TAN; YAO, 2006).

Estudos que relatam diversos pontos de impactos sociais pós-reassentamento, relacionados às comunidades estudadas, poderão ser vistos nos parágrafos subsequentes, atrelados à análise da percepção dos moradores do reassentamento Vila da Terra.

No trabalho de Scott (2006), processos de adoecimento, sofrimento e administração de saúde, como fases dos impactos sociais de grandes projetos em desenvolvimento, foram resultantes do reassentamento realizado para a construção da Usina de Itaparica pela Companhia Hidroelétrica do São Francisco (CHESF), próximo à cidade de Petrolândia, no estado de Pernambuco, hoje conhecida como Usina Luiz Gonzaga.

Já o declínio na geração de renda foi um ponto estudado por Wilmsen, Webber e Duan, (2011), que relataram os efeitos do reassentamento de lares agrícolas de duas aldeias dentro da área inundada pela barragem da hidroelétrica chinesa, propondo um quadro político-econômico para entender o programa de reassentamento e suas implicações para as famílias. Como resultados, esses autores encontraram evidências de que os rendimentos agrícolas das famílias diminuíram, não sendo compensadas pelo aumento dos rendimentos adicionais de trabalhos remunerados propostos, tampouco pelos trabalhos autônomos, o que tornou as famílias mais vulneráveis a novos choques externos do que antes do reassentamento.

Por sua vez, discordâncias no processo de legalização do reassentamento foi um fator que surgiu no estado de Tocantins, na Usina Hidrelétrica de Luís Eduardo, onde o processo de negociação da transição para o reassentamento de Magalhães apresentou tensão. Houve forças de resistência, insegurança da população e sentimento de exclusão por causa da não participação coletiva dos reassentados nas etapas precedentes à implantação dos projetos de reassentamento (PARENTE, 2015).

O mesmo aconteceu com os indivíduos que formam o Movimento dos Atingidos por Barragens (MAB), desapropriados em função da construção da Barragem de Dona Francisca, no estado do Rio Grande do Sul, relatado em Mera et al. (2018), e com a Comunidade Rural de São Sebastião do Soberbo, atingida pela construção da Usina Hidrelétrica Risoleta Neves, em Minas Gerais, apresentada na pesquisa de Fonseca et al. (2015). Entre as diversas insatisfações, a questão judicial foi a mais evidente (MERA et al., 2018).

Em contrapartida, a pacificação no processo judicial compõe a análise realizada com a Comissão Regional dos Atingidos por Barragens do Rio Iguaçu (CRABI), no assentamento dos ribeirinhos atingidos pela construção da Hidrelétrica de Salto Caxias, no estado do Paraná, conforme Derrosso e Ichikawa (2013). Nesse estudo, foram detectadas unicidade e organização da população e sinergia entre a empresa e a participação da população na CRABI, movimento social que procurou ser um interlocutor da população ribeirinha com as forças do estado.

Alguns estudos associam o novo local a um processo de isolamento social, alegando que a população dedica muito tempo para o trabalho e pouco tempo para a convivência social em comunidade. É o caso do reassentamento coletivo Nova Mutum Paraná, oriundo da antiga vila de Mutum-Paraná, em Rondônia, cujos indivíduos se ressentiam quanto à diferença na paisagem natural, como existência de poucas árvores e ausência de sombra 
nos quintais. O deslocamento rompeu com as fortes relações dos moradores com o local de origem, a sensação de pertencimento ao lugar, a harmonia com a paisagem natural como fonte de lazer para realizar caçadas nas matas da região, pescar nos rios, banhar-se nos riachos, jogar futebol e frequentar a igreja (RIBEIRO; ANDRADE; MORET, 2015).

Vantagens na qualidade de vida também são apontadas nos estudos consultados, como no caso dos agricultores organizados pelo MAB da Barragem de Dona Francisca, no estado do Rio Grande do Sul (MERA et al., 2018), e dos moradores do reassentamento Mariana, oriundos da Usina Hidrelétrica Luís Eduardo Magalhães, no estado do Tocantins (SANTOS; SOUZA; PREVIERO, 2016). Neste último, as vantagens geradas na manutenção e no adensamento da vegetação nos quintais ao longo dos anos no reassentamento são reflexos dos elementos sociais e culturais, que representam a sensibilidade ambiental dos moradores e mantenedores desse espaço. Os moradores relataram também outros benefícios associados aos quintais agroflorestais, tais como: qualidade de vida proporcionada pelo sombreamento das residências e espaço usado como área de lazer entre as famílias, tanto para eventos de datas comemorativas como para reunião no horário do almoço e no final da tarde (SANTOS; SOUZA; PREVIERO, 2016).

Outro aspecto muito relevante são as relações de uso, manejo e produção da terra. Como as comunidades reassentadas são majoritariamente agrícolas, esse fato se torna crucial para a continuidade desse saber, passado, muitas vezes, de geração para geração. No reassentamento coletivo Nova Mutum Paraná (RIBEIRO; ANDRADE; MORET, 2015), no reassentamento da Usina Hidrelétrica de Luís Eduardo Magalhães (PARENTE, 2015) e no coletivo de agricultores organizados pelo MAB da Barragem de Dona Francisca (MERA et al., 2018), as novas formas de produzir e comercializar alteraram a dinâmica diária das famílias. Esses mesmos autores registraram também a percepção das comunidades quanto às mudanças das relações sociais com a vizinhança, em que prevaleceram a amizade e a dinâmica de compadrio, incluindo ajuda mútua em épocas de colheita e no cuidado com as crianças.

Dificuldades de adaptação ao novo relevo e paisagem para continuidade dos saberes agrícolas também foram considerados impactos por Roquetti et al. (2017), no caso da construção da Usina Hidrelétrica de Barra Grande, que retirou os agricultores das encostas íngremes do rio Pelotas para colocá-los nas áreas planas dos municípios afetados. Além disso, a criação do reservatório de água também diminuiu a oferta de áreas produtivas nas encostas do rio. Esse deslocamento forçou os produtores rurais a lidar com novas condições ecológicas para dar continuidade a seus modos de vida e produção. Fatores como declividade, acidez do solo, fertilidade, umidade e microclima diferem significativamente nas encostas e nos campos, além do aumento do preço da terra nas áreas planas em razão da especulação da compensação financeira oferecida para quem não quis ir para reassentamento rural coletivo.

Por outro lado, houve resultados positivos quanto à adaptação aos novos modos de produção no reassentamento dos ribeirinhos atingidos pela construção da Usina Hidrelétrica de Salto Caxias, no estado do Paraná, pelo fato de ter ocorrido um aprendizado dos ribeirinhos que seriam deslocados, em razão da construção de outras hidrelétricas na região, e por terem se mobilizado em tempo para evitar maiores perdas, ou seja, os movimentos sociais, com ação coletiva, ajudaram no reforço de uma identidade social, em que os sujeitos envolvidos passaram a partilhar de uma identidade coletiva e positiva da situação (DERROSSO; ICHIKAWA, 2013). 
Já o aumento da produção foi um indicador na percepção dos moradores do reassentamento Mariana, oriundos da Usina Hidrelétrica Luís Eduardo Magalhães, pois as mudanças das espécies outrora plantadas e as comercializações tanto dos frutos quanto das polpas aumentaram no reassentamento. Os proprietários dos quintais agroflorestais começaram a ser beneficiados com o retorno financeiro, dessa forma eles passaram a investir de forma sustentável na manutenção e diversificação das espécies nativas ou exóticas (SANTOS; SOUZA; PREVIERO, 2016).

A infraestrutura física também foi um atributo considerado no reassentamento da Usina Hidrelétrica de Luís Eduardo Magalhães (PARENTE, 2015) e na Comunidade Rural de São Sebastião do Soberbo, atingida pela Usina Hidrelétrica Risoleta Neves (FONSECA et al., 2015). Nas entrevistas de Parente (2015), a comunidade relatou que o tamanho dos lotes rurais era incompatível com a necessidade produtiva das famílias. Já no estudo de Fonseca et al. (2015), os entrevistados indicaram que as casas do reassentamento eram superiores as de outrora $-65 \%$ dos entrevistados alegaram a melhora nas moradias -, além do fato de terem as ruas asfaltadas.

A localização geográfica em relação aos centros comerciais mais próximos foi uma questão abordada por Ribeiro, Andrade e Moret (2015) em Nova Mutum Paraná. Em Mera et al. (2018), os agricultores organizados pelo MAB da Barragem de Dona Francisca, no estado do Rio Grande do Sul, sentiam-se em isolamento por não haver comércio, pelo fato de o transporte público ocorrer somente três vezes por semana e pelas estradas precárias, até mesmo para carros pequenos, o que acarretava constantes manutenções, onerando as famílias e dificultando o acesso aos serviços de saúde, educação e trabalho.

A fim de ter mais assertividade para escolha de uma área destinada ao reassentamento, Scott (2006) aplicou uma metodologia de análise multicritério (Analytic Hierarchy Process - AHP), levando em consideração os critérios de topografia das áreas, aptidão para cultivos diversos, possibilidade de ocupação humana, distância da bacia do rio São Francisco e restrições legais. Já Vilela et al. (2017) classificaram 10 hectares distribuídos em 290 áreas que seriam ideais para a criação de reassentamentos rurais provenientes das desapropriações do projeto de Integração do Rio São Francisco, mais especificamente no Ramal Agreste, nos municípios de Sertânia e Arcoverde, no estado da Paraíba, porém, neste caso, não houve uma avaliação da percepção dos reassentados após essa definição.

No âmbito geral, o processo de adaptação apresenta dificuldades no novo território, principalmente nas memórias afetivas. No estudo realizado com reassentados de barragens no Rio Grande do Sul, os entrevistados diziam que: "sempre quando a gente vai falar, dá uma saudade imensa, porque era muito diferente" (MEDEIROS; LINDER, 2014, p. 270).

Observa-se na literatura disponível sobre reassentamentos que a maior parte dos estudos sobre reassentados se refere ao deslocamento por barragens de hidrelétricas, especialmente no caso do Brasil, dado o vasto número de construções dessa natureza. Logo, analisar esse aspecto tendo um complexo portuário como fonte de impacto torna-se muito significativo, uma vez que existem poucas referências a esse respeito.

O Relatório de Impacto Ambiental de 2006, no levantamento dos impactos no meio social, realizou estudos sobre a organização e a dinâmica territorial com base na sua lógica de organização, auxiliando na avaliação da interferência do empreendimento sobre os padrões de assentamento e mobilidade da população local e as bases econômicas local 
e regional. De acordo com o relatório, na área de influência direta do empreendimento, existiam vínculos de dependência dos recursos naturais terrestres e marinhos. Esses vínculos tinham como centralidade as atividades de pesca, pequena agricultura de subsistência e ocupação para segunda residência de veraneio para o perfil de classe média (MMX, 2006).

A percepção dos futuros impactos sociais foi identificada por meio de pesquisa realizada com os pescadores, que relataram receio que o empreendimento reduzisse ainda mais o campo de pesca, pois ali estavam localizados seus principais pesqueiros. Em contrapartida, reivindicavam o reconhecimento de sua situação, uma política de atendimento a seus interesses e a busca de alternativas para o desempenho de sua atividade. Os moradores litorâneos demonstraram temor que a área se transformasse em um espaço industrial e que, com isso, tivessem de abandonar sua vocação turística, o que penalizaria aqueles que viviam da prestação de pequenos serviços associados à atividade turística e de veraneio. Já os ocupantes da Fazenda Saco Dantas relataram o receio de terem que desocupar a área sem uma alternativa para o plantio, perdendo as benfeitorias realizadas nos lotes, e renunciar a colheita. Ainda, as comunidades interioranas manifestaram insegurança com a construção do porto por causa do crescimento do fluxo de veículos, com prejuízo para configuração espacial e social em que viviam, e enfatizaram também a inexistência de asfaltamento na maioria das comunidades. O receio pela chegada de pessoas de outras regiões, o que poderia prejudicar e interferir no cotidiano dessas populações locais, também foi apontado (MMX, 2006).

As expectativas da população em geral quanto ao Complexo Industrial do Porto do Açu foram registradas por Piquet e Shimoda (2014), que pesquisaram a percepção das populações dos municípios de São João da Barra e Campos dos Goytacazes quanto aos impactos econômicos e à oferta de serviços que o empreendimento portuário provocaria localmente. A pesquisa de campo considerou os itens emprego, segurança, trânsito, educação, saúde, comércio, meio ambiente, preço de produtos e serviços, agricultura, água e saneamento. Como resultado, mais de $50 \%$ da população de São João da Barra considerou que a instalação iria melhorar muito os aspectos da empregabilidade, o setor de educação, o comércio, a distribuição de energia, as condições gerais do abastecimento de água e saneamento básico (PIQUET; SHIMODA, 2014).

Da mesma forma, Lopes et al. (2011) indicaram que 70\% da população tinha expectativa de desenvolvimento da região e considerava o empreendimento portuário como muito bom e que $90 \%$ dos pesquisados reportaram que estavam esperançosos em melhorar sua condição de vida em função do empreendimento.

Em contraponto, forças de resistências foram apresentadas por parte da população rural diretamente atingida, provenientes do $5^{\circ}$ distrito de São João da Barra. Essas comunidades, segundo estudos, tinham como principais atividades a pesca, a criação de animais (suínos, aves e bovinos) e a administração de pequenos estabelecimentos comerciais. Os motivos de resistências estavam atrelados à desconsideração ao sentimento de pertencimento em relação ao território em que viviam, exclusão de todo o processo decisório e fragmentação do processo de desapropriação, onde novas áreas eram anexadas ao projeto do complexo, instaurando na população tensão e incertezas. Então a Associação de Proprietários Rurais e de Imóveis do Município de São João da Barra (ASPRIM) foi criada como interlocutora da população com a empresa (PRADO; ROCHA, 2015). 


\section{3. Área de estudo}

O reassentamento Vila da Terra localiza-se em São João da Barra, município que possui uma área total de $452,894 \mathrm{~km}^{2}$, correspondentes a 4,7\% da área do Norte Fluminense, e uma população estimada, em 2019, de 36.102 habitantes, equivalente a 3,9\% do contingente dessa região.

O município tem como principais atividades econômicas o turismo, agropecuária, olericultura, fruticultura ativa, artesanato e pesca. Entretanto, a maior parte das receitas municipais está concentrada nos royalties e no recolhimento do Imposto Sobre Serviços (ISS) (RIO DE JANEIRO, 2019). Na Figura 1, é apresentada a evolução da arrecadação de ISS e royalties no município, em que se observa que, em 2001, a arrecadação de ISS representava menos de R $\$ 1$ milhão, correspondendo a cerca de 3\% das receitas do município, enquanto, em 2017, já representava $16,8 \%$ das receitas municipais (RIO DE JANEIRO, 2019). O crescimento do ISS indica uma fonte de receita que reduz a dependência do município dos royalties, os quais representam valores expressivos, mas apresentam grande volatilidade.

A Vila da Terra foi construída na Fazenda Palacete, em São João da Barra, como uma das ações propostas no reassentamento das famílias, sendo destinada uma área mínima de 2 hectares para cada reassentado, e em cada propriedade foi construída uma casa com medidas entre 68 e $109 \mathrm{~m}^{2}$, com dois, três ou até quatro quartos. Todas as 53 residências possuíam máquina de lavar, televisor, geladeira, fogão e computador, além dos móveis de sala e de quarto e armários de cozinha.

$\mathrm{O}$ reassentamento fica próximo à Rodovia BR-356 e à Rodovia RJ-240, que são vias que dão acesso aos municípios de São João da Barra e Campos dos Goytacazes e ao

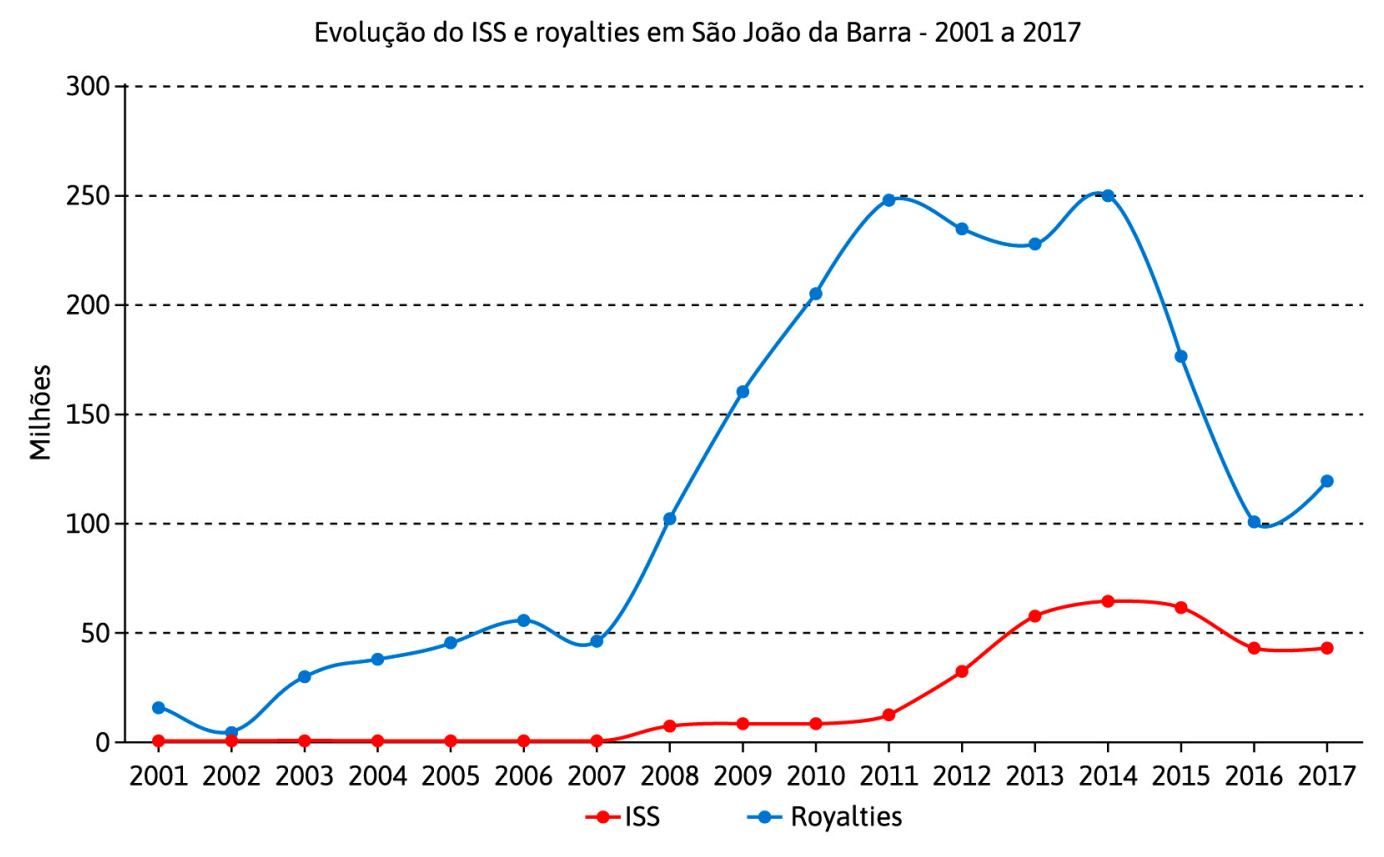

Figura 1 - Evolução do ISS e royalties de 2001 a 2017 em São João da Barra.

Fonte: elaborada pelas autoras com base em Rio de Janeiro (2019). 
Porto do Açu, respectivamente. A localidade faz parte da área de influência direta do empreendimento portuário. A Figura 2 apresenta um cartograma com a localização da Vila da Terra e seu posicionamento geográfico em relação ao Porto do Açu e à sede de São João da Barra.

\section{Materiais e Métodos}

Para identificar a percepção de reassentados em relação às alterações provocadas nos diversos aspectos da sua vida, foi realizado um levantamento censitário por meio de um questionário estruturado. A pesquisa foi aprovada pelo Comitê de Ética das Ciências Humanas e Sociais Aplicadas, e cada entrevistado assinou o Termo de Consentimento Livre e Esclarecido. É importante salientar que a aplicação do questionário não ofereceu nenhum risco físico ou constrangimento aos participantes. Ainda, se algum entrevistado

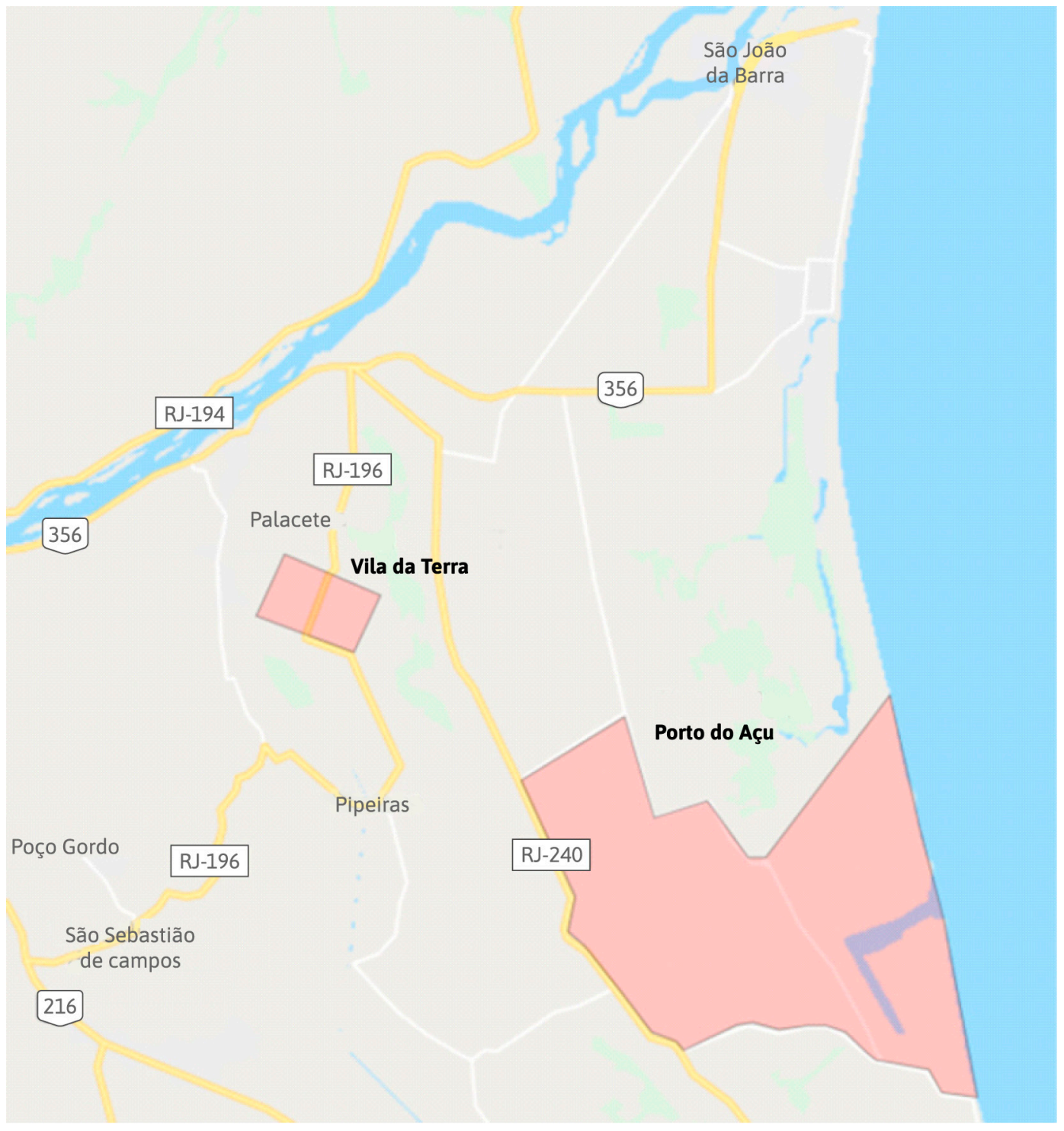

Figura 2 - Localização da Vila da Terra.

Fonte: adaptada pelas autoras a partir do Google Maps. 
se sentisse desconfortável em responder a alguma questão, o quesito não era respondido ou o questionário era interrompido.

O questionário foi estruturado em três blocos: bloco A - dados de identificação e caracterização dos indivíduos; bloco B - investigação da vida no local de origem; bloco C - investigação da vida na Vila da Terra. Os atributos considerados para análise comparativa estarão relacionados ao perfil geral dos entrevistados, uso e manejo da terra, comercialização da produção, relações sociais, infraestrutura da moradia, localização geográfica, mobilidade urbana e lazer, e processo de negociação. Também foram feitas questões abertas quanto à moradia anterior e à atual, para que o entrevistado ficasse à vontade para se expressar.

Após a coleta e análise crítica, os dados foram processados e tabulados por meio do software IBM SPSS Statistics, sendo realizada uma análise descritiva dos dados.

\section{Resultados}

Foram realizadas 40 entrevistas, das quais 30 se referiram a assentados originais e 10 não foram elegíveis, pois eram compostas por novos moradores que compraram terrenos de reassentados (3 casos), ocupavam casas cedidas ( 2 casos) ou residiam de aluguel no reassentamento (5 casos). Em maioria, $40 \%$ (16) das famílias viviam no $5^{\circ}$ Distrito de São João da Barra, e 35\% (14), na antiga Fazenda Saco Dantas, áreas desocupadas para implantação do Porto do Açu.

Considerando os 30 reassentados elegíveis, identificou-se que 53\% eram homens e $47 \%$ eram mulheres. A maior parte tinha idade entre 29 e 69 anos, sendo que $40 \%$ possuíam de 29 a 49 anos; 47\%, entre 50 e 69 anos; e 13\%, 70 anos ou mais. A escolaridade em geral era baixa, já que $43 \%$ deles declararam que não sabiam ler e escrever; $43 \%$ não completaram o ensino fundamental; $7 \%$ possuíam o ensino fundamental completo; $3 \%$ completaram o ensino médio; e 3\% tinham ensino superior. Os casados e em união estável somavam 77\%; os solteiros, $13 \%$; os viúvos, 7\%; declararam outras situações, $3 \%$. Quanto ao tamanho dos domicílios, verificou-se que $13 \%$ eram unipessoais; $33 \%$, compostos por duas pessoas; e $40 \%$, por três pessoas.

A atividade de agricultor era exercida com exclusividade por $43 \%$ dos chefes de família; de comerciante, por $10 \%$; de pesca, $3 \%$. Além disso, $3 \%$ eram aposentados. O tempo de moradia na Vila da Terra variava de 4 a 9 anos, sendo que $40 \%$ viviam no local há 7 anos; $20 \%$, há 8 anos; e $7 \%$, há 9 anos.

Em convergência com os trabalhos de Parente (2015) e Fonseca et al. (2015), a infraestrutura física comparativamente ao local de origem foi percebida pelos reassentados como melhor, com ênfase para: quantidade de dormitórios, os quais, em 29 casas, eram iguais ou superiores à da casa original; terreno independente para 12 famílias que moravam anteriormente em terrenos compartilhados com outros membros do grupo familiar; piso em cerâmica; acesso a redes de telefonia móvel; eletrodomésticos e móveis novos. Foram apontados como positivos também o material construtivo da cobertura da residência, composta por laje junto ao telhado de cerâmica, e as vias pavimentadas com acesso mais próximo aos centros de São João da Barra e Campos dos Goytacazes.

Quanto ao uso e manejo da terra, a classificação da fertilidade da terra revelou que 17 famílias (56,7\%) apontaram a terra da moradia anterior como fértil, sendo que, na Vila 
da Terra, 24 famílias (80\%) indicaram essa classificação. Esse aumento teve contribuição de famílias que consideravam a terra anterior pouco fértil (no caso, 7 famílias, ou 23,3\%) e que, em sua percepção, a terra disponibilizada passou a ser classificada como fértil. Das espécies mais vendidas na localidade anterior, destacavam-se o quiabo (relatado por 11 famílias), o maxixe (10 famílias) e a mandioca, ou aipim (3 famílias). Em contrapartida, na Vila da Terra, a mandioca foi reportada como a cultura mais vendida (14 famílias), seguida pelo quiabo ( 7 famílias) e pelo maxixe ( 5 famílias). Em que pese à menor criação de animais na Vila da Terra, em contrapartida os assentados contavam com acesso gratuito à assistência técnica e maquinário para uso e manejo na terra, o que não dispunham na localidade anterior.

Esses resultados apresentam aderência com o trabalho de Santos, Souza e Previero (2016), que relataram percepção de melhora na produção agrícola pelos moradores do reassentamento Mariana, oriundos da Usina Hidrelétrica Luís Eduardo Magalhães, pois as mudanças das espécies outrora plantadas e as comercializações tanto dos frutos quanto das polpas aumentaram no reassentamento. Da mesma forma, Derrosso e Ichikawa (2013) relataram experiências positivas percebidas pelos atingidos em razão da construção da Usina Hidrelétrica de Salto Caxias, no estado do Paraná.

A localização geográfica em relação aos centros comerciais mais próximos foi uma questão abordada por Ribeiro, Andrade e Moret (2015) e por Mera et al. (2018). Para os reassentados da Vila da Terra, esse atributo apresentou ganhos, uma vez que eles se localizavam mais próximos aos centros de São João da Barra e Campos dos Goytacazes, possuíam vias asfaltadas e transporte público passando em frente às residências e gratuito para São João da Barra.

A questão de capital social foi valorizada pelos reassentados, que, em geral não consideraram que houve prejuízo nas relações sociais com a mudança: 22 apontaram o relacionamento com os vizinhos da comunidade anterior como "Bom" e mantiveram essa indicação na Vila da Terra; 2 transitaram de "Bom" na residência anterior para "Ótimo" na Vila da Terra; 2 passaram de "Regular" no local de origem para "Ótimo" e "Bom" na Vila da Terra. Em contrapartida, 4 entrevistados relataram que deixaram de se socializar, assim como 6 deixaram de ter sensação de segurança na Vila da Terra. Isso se deve, provavelmente, ao número de roubos de que tiveram conhecimento no novo espaço, em relação à residência anterior (7 na residência anterior e 29 na Vila da Terra).

A relação com o lugar anterior foi fortemente relacionada com a paisagem e os laços afetivos, já que os recursos naturais foram reportados por 15 reassentados, e os laços afetivos, por 21.

Os pontos positivos, relatados de forma livre pelos reassentados, quando perguntados sobre o que mais gostavam na Vila da Terra, foram agrupados pelos atributos de localização, infraestrutura, ambiental, social e financeiro. A localização foi um ponto recorrente, por se situar mais próximo aos centros de São João da Barra e Campos dos Goytacazes, relatado por 18 pessoas; na sequência, vieram a fertilidade da terra (8 pessoas), a casa nova ( 7 pessoas) e a tranquilidade do local (5 pessoas).

A média de renda familiar apresentou um aumento de $186 \%$, passando de $\mathrm{R} \$ 697,00$ para $\mathrm{R} \$ 1.997,00$. Acrescenta-se ainda que $75 \%$ das famílias que recebiam uma renda familiar de até $\mathrm{R} \$ 1.000,00$ na residência anterior passaram a receber, na Vila da Terra, uma renda familiar de até $\mathrm{R} \$ 2.400,00$. A renda média mensal oriunda dos bens da terra, comparada à vida anterior ao reassentamento, apresentou melhora, sendo o aumento 
da renda média de $\mathrm{R} \$ 513,33$ para $\mathrm{R} \$ 643,00$, o que representou 125\% de acréscimo, e $75 \%$ das pessoas que recebiam renda de até $R \$ 800,00$ na residência anterior passaram a receber R \$1.100,00 na Vila da Terra. Esses resultados divergem do trabalho de Wilmsen, Webber e Duan (2011), que avaliaram os efeitos do reassentamento de lares agrícolas de duas aldeias dentro da área inundada pela barragem da hidroelétrica chinesa. Como resultados, esses autores encontraram evidências de que os rendimentos agrícolas das famílias diminuíram, não sendo compensados pelo aumento dos rendimentos adicionais de trabalhos remunerados propostos ou trabalhos autônomos, o que tornou as famílias mais vulneráveis a novos choques externos do que antes do reassentamento.

O sentimento de tristeza no dia da mudança foi relatado por 14 (46,7\%) entrevistados. Em contrapartida, 8 (26,7\%) disseram se sentir felizes com a mudança, 7 (23,3\%) se mostraram indiferentes e $1(3,3 \%)$ não soube responder. Relatos de adoecimento e sofrimento não foram detectados, como exposto em outros reassentamentos estudados, como no caso da construção da Usina de Itaparica pela CHESF, próximo à cidade de Petrolândia, no estado de Pernambuco, hoje conhecida como Usina Luiz Gonzaga (SCOTT, 2006). Tal fato pode ser ancorado quando se compara a vida na casa anterior ao reassentamento com a vida na Vila da Terra.

\section{Considerações finais}

Pode-se observar, por meio deste estudo, a importância da busca em perceber, pesquisar e registrar o sentimento das famílias reassentadas, tendo em vista os vários impactos ocorridos na vida das 30 famílias entrevistadas, considerando que algumas já estavam reassentadas há quase 9 anos.

Como visto, os impactos dos atributos pesquisados, em linhas gerais, são expostos pelos reassentados como pontos de melhora, principalmente nos tópicos relacionados à nova localização, fertilidade da terra e posse individual para aqueles que compartilhavam suas casas em terrenos cedidos. Ainda, pode-se observar pelo tempo de permanência no reassentamento que a maioria das famílias se adaptou ao plantio, tendo essa prática inclusive crescido. No quesito emocional, fica clara a tristeza no dia da mudança, pois o vínculo com casa original construída pela maioria das famílias, o apreço ao local de origem, as memórias e a saudade são sentimentos que irão perdurar. Além disso, pode-se elencar a queda no sentimento de segurança e no hábito de socializar, atributos emocionais desafiadores para serem reconstruídos.

Não cabe a este texto julgar que os ganhos físicos e materiais se sobrepõem aos emocionais, mas os atributos de satisfação dos reassentados quanto à nova vida, no comparativo entre a casa anterior e a Vila da Terra, permitem afirmar que as suas vidas mudaram para melhor. Esse resultado é raramente encontrado quando se trata de reassentamentos compulsórios, como os casos de estudos tomados como base neste trabalho, nos quais a maioria apresentou insatisfações e dificuldades por parte dos reassentados.

O registro da percepção das famílias reassentadas torna-se de extrema importância para a contribuição e o acúmulo de conhecimento para futuros deslocamentos compulsórios, até mesmo para subsidiar o escopo de uma legislação que possa vir a ser proposta no âmbito governamental. As comunidades não devem ficar sem ouvidoria em sua nova 
vida, sendo os estudos acadêmicos uma ferramenta que pode e deve ser usada para preencher essa lacuna na legislação.

\section{Referências bibliográficas}

BRASIL. Senado Federal. Constituição Federal de 1988. Diário Oficial [da] República Federativa do Brasil, Poder Executivo, Brasília, DF, 1988.

CORPORAÇÃO FINANCEIRA INTERNACIONAL - IFC. Padrões de desempenho sobre sustentabilidade socioambiental. 2012. Disponivel em: <https://www.ifc.org/wps/wcm/connect/f2679b79-e082-4bc9ae04-e5dbee83791d/PS_Portuguese_2012_Full-Document.pdf?MOD=AJPERES\&CVID=jSD0tSw\#: :text $=\mathrm{A} \% 20 \mathrm{IFC} \% 20$ utiliza\%20a\%20Estrututa,aplicados\%20por\%20outras\%20institui\%C3\%A7\%C3\%B5es\%20 financeiras >. Acesso em: 20 mar. 2021.

DERROSSO, G.; ICHIKAWA, E. Y. O papel da Crabi no assentamento dos ribeirinhos atingidos pela construção da hidrelétrica de Salto Caxias no estado do Paraná. Revista de Administração Pública, Rio de Janeiro, v. 47, n. 1, p. 133-155, 2013.

FONSECA, B. C. et al. Análise do estudo de caso da comunidade rural de São Sebastião do Soberbo, atingida pela UHE Risoleta Neves, sob a perspectiva dos conflitos, das ideias e dos argumentos. Revista Geográfica Acadêmica, Paricarana, v. 9, n. 1, p. 116-129, 2015.

FUNDAÇÃO RENOVA. Os sete desafios do reassentamento. Revista dois Pontos, [S.l.], 2018. Disponível em: <https://revistadoispontos.org/materias/desafios-reassentamento/\#>. Acesso em: 19 set. 2019.

HAESBAERT, R. Da desterritorialização à multiterritorialidade. Boletim Gaúcho de Geografia, Porto Alegre, v. 29, n. 1, p. 11-24, 2003.

LOPES, B. S. et al. Complexo Portuário do Açu: Propostas para que a riqueza gerada possa retornar à comunidade de São João da Barra utilizando a ferramenta Accountability. Perspectivas Online: Exatas e engenharia, Campos dos Goytacazes, v. 1, n. 1, p. 23-46, 2011.

MEDEIROS, R. M. V.; LINDER, M. A terretorialização de assentados e reassentados no Rio Grande do Sul: os espaços de vida no contexto da luta pela terra. Revista FSA, Teresina, v. 11, n. 2, p. 234-246, 2014.

MERA, C. M. P. D. et al. Da serra/roça para o território campo/lavoura: transformações socioeconômicas e culturais de reassentados rurais atingidos por barragens. Revista NERA, Presidente Prudente, v. 21, n. 41, p. 62-84, 2018.

MESQUITA, Z. Do território à consciência territorial. In: BRANDÃO, C.; MESQUITA, Z. (Ed.). Territórios do Cotidiano uma introdução a novos olhares e experiências. Porto Alegre: Ed. UFRGS - Ed. UNISC, 1995 p. 76-92.

MMX. Porto do Açu - RJ: RIMA - Relatório de Impacto ao Meio Ambiente. Rio de Janeiro: CAL Consultoria Ambiental., 2006. 722 p.

ORGANIZAÇÃO DAS NAÇÕES UNIDAS - ONU. Declaração Universal dos Direitos Humanos. In: ASSEMBLÉIA GERAL DA ONU, 1948, Paris. Paris: ONU, 10 dez. 1948. Disponível em: <https://www. ohchr.org/EN/UDHR/Pages/Language.aspx?LangID=por>. Acesso em: 19 set. 2019.

PARENTE, T. G. (In)visibilidade de atores no processo de reassentamentos da Usina Hidrelétrica Luís Eduardo Magalhães, no Tocantins. Revista Territórios \& Fronteiras, Cuiabá, v. 8, n. 1, p. 149-164, 2015.

PIQUET, R. P.; SHIMODA, E. De braços abertos: as expectativas quanto aos impactos do Porto do Açu, Rio de Janeiro. Revista Política e Planejamento Regional, Rio de Janeiro, v. 1, n. 1, p. 121-137, 2014.

PORTO DO AÇU. Vila da Terra. Portal da Porto do Açu, 2017. Disponível em: < https://portodoacu.com. br/vila-da-terra/>. Acesso em: 11 nov. 2018.

PRADO, F; ROCHA, B. N. Territórios em Disputa: resistência e luta no processo de implantação do Complexo Industrial Superporto do Açu. Revista Política e Planejamento Regional, Rio de Janeiro, v. 2, n. 2, p. 329-349, 2015.

RIBEIRO, A. M.; ANDRADE, L. C.; MORET, A. S. Os Estabelecidos e os Outsiders da Amazônia: uma reflexão sociológica acerca de um projeto de reassentamento em Rondônia, Brasil. Revista Territórios \& Fronteiras, Cuiabá, v. 8, n. 2, p. 275-290, 2015.

RIO DE JANEIRO. Assembléia Legislativa do Estado do Rio de Janeiro. Decreto no 25455 de 28 de Junho de 1999. Rio de Janeiro, RJ. Disponível em: <http://alerjln1.alerj.rj.gov.br/decest.nsf/c8ea52144c8b5c 950325654c00612d63/59353eecd4d6b5e203256a65005c8595? OpenDocument\&Highlight=0,25455>. Acesso em: 15 out. 2019. 
RIO DE JANEIRO. Decreto no 41.915 de 19 de junho de 2009. Diário Oficial do Estado do Rio de Janeiro, Rio de Janeiro, RJ. Disponível em: <http://www.ioerj.com.br/portal/>. Acesso em: 20 out. 2019.

RIO DE JANEIRO. Tribunal de Contas do Estado do Rio de Janeiro. Estudos socioeconômicos dos municípios do Estado do Rio de Janeiro: São João da Barra. Rio de Janeiro, RJ, 2019. Disponível em: $<$ https://www.tce.rj.gov.br/web/guest/70>. Acesso em: 20 set. 2019.

ROQUETTI, D. R. et al. Deslocamento populacional forçado por grandes barragens e resiliência socioecológica: O caso da Usina Hidrelétrica de Barra Grande no sul do Brasil. Ambiente \& Sociedade, São Paulo, v. 20, n. 3, p. 117-138, 2017.

SANTOS, I. G.; SOUZA, P. B.; PREVIERO, C. A. Quintais agroflorestais na percepção dos moradores do reassentamento Mariana, Tocantins. Revista Verde de Agroecologia e Desenvolvimento Sustentável, Pombal, v. 11, n. 5, p. 95-102, 2016.

SANTOS, M. Espaço e método. São Paulo: Nobel, 1985. 88 p.

SANTOS, M. O dinheiro e o território. In: SANTOS, M. (Ed.). Território, territórios: ensaios sobre ordenamento territorial. 2. ed. Rio de Janeiro: DP\&A, 2006. p. 13-21.

SAQUET, M. A. Reterritorialização e identidade. In: MEDEIROS, R. M. V.; FALCADE, I. (Org.). Tradição versus tecnologia: as novas territorialidades do espaço agrário brasileiro. Porto Alegre: Editora da UFRGS, 2009.

SCOTT, P. Re-assentamento, Saúde e Insegurança em Itaparica: um modelo de vulnerabilidade em projetos de desenvolvimento. Saúde e Sociedade, São Paulo, v. 15, n. 3, p. 74-89, 2006.

SPOSITO, E. S. Geografia e Filosofia: contribuição para o ensino do pensamento. In: SPOSITO, E. S. (Ed.). Geografia e Filosofia: contribuição para o ensino do pensamento. São Paulo: Editora UNESP, 2004. 218 p.

TAN, Y.; YAO, F. Three Gorges Project: effects of resettlement on the environment in the reservoir area and countermeasures. Population and Environment, Providence, v. 27, n. 4, p. 351-371, 2006.

VILELA, W. A. et al. Determination of Potential Areas for Resettlement of Families Affected by the São Francisco River Integration Project Using Geotechnologies. BCG - Boletim de Ciências Geodésica, Curitiba, v. 23, n. 2, p. 338-351, 2017.

WILMSEN, B.; WEBBER, M.; DUAN, Y. Involuntary rural resettlement: resources, strategies, and outcomes at the Three Gorges Dam, China. Journal of Environment \& Development, Santa Barbara, v. 20, n. 4, p. 355-380, 2011.

SOBRE AS AUTORAS

Elaine Cristina Ribeiro Mendes Emerick. Programa de Pós-Graduação em Geografia da Universidade Federal Fluminense, em Campos dos Goytacazes (UFF/Campos). Graduada em Geografia e Pós-graduada em Educação Ambiental pelo Centro Universitário do Leste de Minas Gerais. Aluna do Programa de Pós-Graduação em Geografia da Universidade Federal Fluminense, em Campos dos Goytacazes (UFF/Campos).

Elzira Lúcia de Oliveira. Programa de Pós-Graduação em Geografia da Universidade Federal Fluminense, em Campos dos Goytacazes (UFF/ Campos). Mestre e doutora em Demografia pela Universidade Federal de Minas Gerais (UFMG). Graduada em Ciências Econômicas pela UFMG. Professora associada da Universidade Federal Fluminense (UFF). 


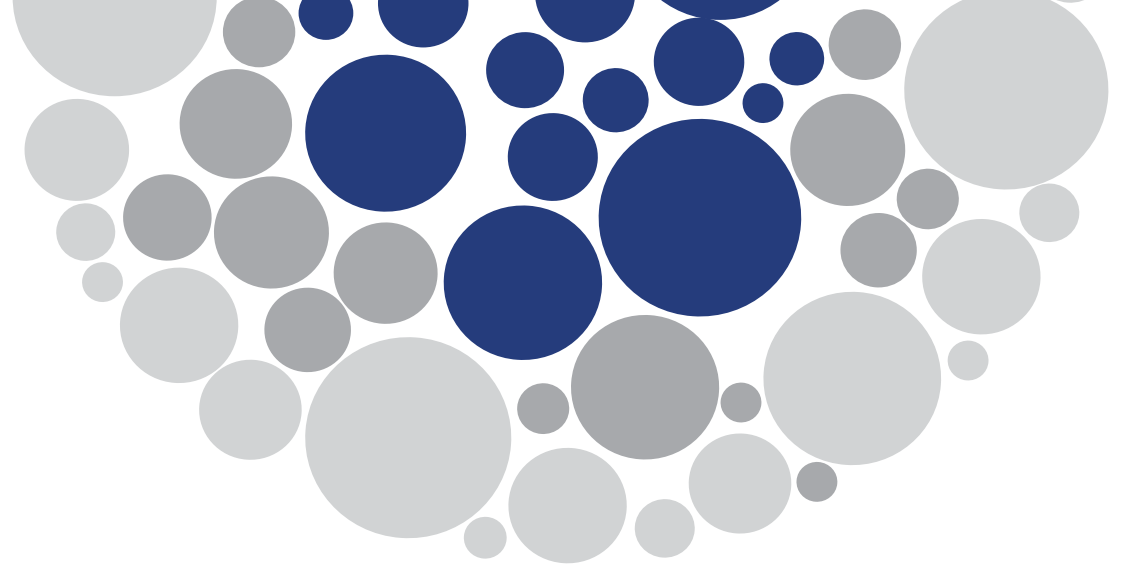

\title{
O Noroeste Fluminense e a atividade leiteira: desafios para a agricultura familiar ${ }^{1}$
}

\author{
Erika Vanessa Moreira Santosa, Samara Venina Simen de Azeredo Silva Chagas \\ Marco Túlio Morais Velasque Silvac \\ a Universidade Federal Fluminense/Programa de Pós-Graduação em Geografia da UFF/CAMPOS, Núcleo de Estudos Rurais \\ e Urbanos (NERU).E-mail: erikamoreira@id.uff.br \\ b Universidade Federal Fluminense/Programa de Pós-Graduação em Geografia da UFF/CAMPOS, Núcleo de Estudos Rurais \\ e Urbanos (NERU). E-mail: samarasimen@id.uff.br \\ c Universidade Federal Fluminense/Curso de Graduação em Geografia (Bacharelado), Núcleo de Estudos Rurais e Urbanos \\ (NERU). E-mail: velasque_marco@id.uff.br
}

\section{Introdução}

A produção leiteira no estado do Rio de Janeiro em 2019 atingiu 432 milhões litros, segundo a Pesquisa Pecuária Municipal, cabendo à mesorregião Sul Fluminense a produção de 130 milhões litros e à região Noroeste Fluminense a produção de 106 milhões de litros. As duas mesorregiões constituem as principais bacias leiteiras do estado e possuem o maior quantitativo de vacas ordenhadas. Todavia, há um déficit entre o consumo e a produção no estado, pois o consumo anual de leite gira em torno de 1,5 bilhão, e a produção é inferior a 500 milhões de litros por ano. Diante desse cenário, programas e políticas públicas têm sido criados para fomentar o incentivo à produção de leite no estado.

Neste texto, o nosso principal objetivo é realizar um panorama da atividade leiteira no Noroeste Fluminense à luz da importância da agricultura familiar, tendo como recorte temporal os anos de 2010 a 2019. Os objetivos secundários visam realizar a contextualização

${ }^{1}$ Este texto é resultado da pesquisa realizada pela equipe com recursos da Pró-Reitoria de Pesquisa, Pós-Graduação e Inovação da Universidade Federal Fluminense (PROPPI/UFF), junto ao Edital FOPESQ/2020. 
da formação socioespacial da região Noroeste Fluminense e compreender os desafios da agricultura familiar diante das políticas públicas. Os procedimentos metodológicos adotados abrangeram levantamento bibliográfico e de dados secundários no Sistema IBGE de Recuperação Automática (SIDRA), na Secretaria Estadual da Fazenda (SEFAZ) e na Empresa de Assistência Técnica e Extensão Rural (EMATER-Rio) e realização de entrevistas semiestruturadas com responsáveis de instituições como EMATER-Rio e Serviço Nacional de Aprendizagem Rural (SENAR).

É importante valorizar a agricultura familiar e destacar as dificuldades enfrentadas na região Noroeste Fluminense, onde, de um lado, há programas e projetos políticos para a sua inserção em um modelo de binômio agricultura-indústria e, de outro, há discursos sempre renegando-a a uma condição de 'região-problema', seja pelos indicadores sociais e econômicos, seja pela perda populacional em alguns municípios, como Laje de Muriaé, Miracema, Natividade e Itaocara.

Para a construção deste texto, organizamos as ideias em quatro seções, além desta introdução e das considerações finais. A primeira seção faz uma contextualização histórica da atividade leiteira no Brasil e no Rio de Janeiro. A seção seguinte é voltada para uma caracterização da região Noroeste Fluminense. A terceira seção apresenta o percurso da atividade leiteira na região Noroeste Fluminense. E, por último, mas não menos importante, a quarta seção analisa o papel das instituições e das políticas públicas de fomento à atividade leiteira e os desafios para a agricultura familiar.

\section{A atividade leiteira no Brasil e no Rio de Janeiro}

A pecuária leiteira está presente no país desde o período colonial, sobretudo nas áreas de exploração do ouro em Minas Gerais, e, segundo Prado Junior (2011), era fonte de abastecimento alimentar na exploração das minas. No entanto, existem diferenças entre a pecuária no Sertão do Nordeste, Campos do Sul e Sul de Minas, sendo que, nessa última localidade, há uma significativa exploração da pecuária leiteira e o processamento dos seus derivados (PRADO JUNIOR, 2011; VALVERDE, 1967). Orlando Valverde (1967), no texto "Geografia da pecuária", também destaca que, no século XVI, a criação de gado era proibida até 10 léguas da costa, "salvo na ilha de Joanes e nos Campos dos Goytacazes".

Segundo Santos (2004), antes do século XIX, não existia uma especialização da pecuária leiteira, sendo que a primeira raça introduzida no Brasil foi a turino, trazida de Portugal. Já a raça holandesa só chegou no início do século XX, nas invernadas das cidades de Salvador e Rio de Janeiro.

Até 1920, ano de implantação da Nestlé no Brasil, não havia no país, uma empresa especializada na produção de derivados lácteos e as duas maiores cidades da época Rio de Janeiro e São Paulo - realizavam a importação de alguns derivados, como queijo e manteiga europeus. $\mathrm{O}$ aumento do consumo de leite e derivados nessas cidades, consequência do crescimento urbano acelerado das primeiras décadas do século XX, estimulou o Sul de Minas a se transformar na primeira região especializada na produção leiteira no Brasil [...] (SANTOS, 2004, p. 52).

Até os anos 1950, a produção era baixa, se comparada a outros países, como Holanda e França, ou seja, a produção era de 2 litros por vaca. Outrossim, o consumo de leite e seus derivados também era baixo, pois a produção era de alto custo, e "o seu preço 
é artificialmente elevado pelas empresas e cooperativas que exploram o comércio" (VALVERDE, 1967, p. 259). A partir de 1950, no pós-guerra, Valverde (2020 [1967]) retrata que a instalação de fábricas no Brasil (Glória, Nestlé, Mococa etc.) reorganizou a produção e ampliou a demanda do leite cru para seu processamento.

A instalação da Nestlé no Brasil ocorreu em 1920, em São Paulo, e, no ano de 1936, a empresa instalou sua fábrica no estado do Rio de Janeiro, no município de Barra Mansa, com a produção de leite pasteurizado, leite condensado e outros derivados lácteos (SANTOS, 2004). Wilkinson (2007, p. 354) destaca que, entre 1940 e 1990, o setor leiteiro brasileiro estava em uma fase de ajustamento à demanda urbano-industrial, com a regulamentação do leite, a pasteurização e, por conseguinte, o surgimento do tipo c (saquinho) e do tipo b. Nos anos 1980, Wilkinson (2007) aponta ainda o aumento da demanda do leite e seus derivados tanto pelo incremento do consumo da classe média urbana como pela atuação de empresas multinacionais.

Com a crise dos anos 1980 e a abertura da economia nos anos 1990, ocorreu o aumento da produção de leite tipo longa vida (UHT). Tal incremento "não foi a inovação em si, mas a capacidade financeira e de agir em âmbito nacional e mesmo internacional que selava a superioridade competitiva da Parmalat, que liderava esta inovação e iria desestruturar o sistema cooperativo" (WILKINSON, 2007, p. 357). Houve, portanto, aquisições e fusões no setor lácteo, lideradas pela Nestlé e Parmalat.

Nos anos 1990, com a implantação do Plano Real e a estabilização econômica, a produção de lácteos exibiu um incremento diante da crescente demanda urbana, do aumento da renda e da integração nacional dos mercados. Segundo Wilkinson (2007), no final dos anos 1990, algumas normatizações foram estabelecidas, tais como a Portaria do Programa Nacional da Qualidade do Leite (1999), a Instrução Normativa no 51 (BRASIL, 2002), entre outras.

O consumo de leite e seus derivados vem aumentando no século XXI. Segundo o estudo de Camilo (2018, p. 5), “[...] a CONAB aponta para um aumento médio per capita de 4,3\% a.a. nos últimos 14 anos, passando de $122 \mathrm{~kg} /$ pessoa/ano em 2000 para $168,2 \mathrm{~kg} /$ pessoa/ano em 2014. Neste ritmo, em 2023, o consumo per capita poderá atingir cerca de $220 \mathrm{~kg} /$ habitante/ano".

Os principais derivados produzidos pela indústria de laticínios brasileira são os queijos (Prato e Mussarela), leite UHT e leite em pó (integral e desnatado). Afirma o IBGE que apenas $70 \%$ do leite produzido vai para a indústria (leite formal), cerca de 24,5 bilhões de litros, sendo que, deste montante, apenas $68 \%$ é inspecionado por órgãos federais. Do total de leite formal, segundo a CONAB (2013), cerca de 70\% (17,4 bilhões de litros) são envasados em forma de leite fresco (Ultra High Temperature - UHT, refrigerado barriga mole), 25\% (6,1 bilhões de litros) são para a produção de queijos e 2,5\% (500 milhões de litros) são destinados à produção de leite em pó (integral e desnatado), o restante, 2,5\% (500 milhões de litros), compõe a produção de cremes, iogurtes, bebidas lácteas e manteiga (CAMILO, 2018, p. 5).

No decurso dessa breve contextualização sobre a atividade leiteira no Brasil, vários agentes foram responsáveis pela reorganização produtiva, seja no tocante ao processamento de lácteos, seja na espacialização da produção. O Estado atuou, outrora, nas questões legislativas e normativas e nos programas de fomento à produção. Segundo Camilo (2018, p. 75), a atuação do Estado na cadeia produtiva do leite acontece em três frentes: 
na produção (fomento à produção e tabelamento), na qualidade dos lácteos (fiscalização e normas) e na demanda/consumo (programas sociais e políticas econômicas).

Os dados da Estatística da Pecuária do Instituto Brasileiro de Geografia e Estatística (2020) mostram, por meio da Figura 1, o comportamento da produção de leite no intervalo de 2015 a 2020 no Brasil.

Mesmo diante da pandemia da Covid-19, a produção de leite ampliou de 6,28 bilhões de litros em 2019 ( $3^{\circ}$ trimestre) para 6,45 bilhões de litros em 2020. Esse aumento da produção se refletiu no incremento do valor pago ao produtor de $\mathrm{R} \$ 1,38$ por litro (2019) para R\$1,94 (2020); todavia, esse valor é médio, e há alterações entre as unidades da federação e nas microrregiões geográficas.

A atividade leiteira no estado do Rio de Janeiro se concentra no Médio Paraíba e no Noroeste Fluminense e é incentivada desde 1977, sendo que, neste século XXI, há três instrumentos normativos sobre os incentivos estaduais à produção de leite: o Decreto $\mathrm{n}^{\circ} 29.042$, de 27 de agosto de 2001; o Decreto n $^{\circ} 41.765$, de 20 de março de 2009 (RIO DE JANEIRO, 2009); e o Decreto no 46.198, de 18 de dezembro de 2017 (RIO DE JANEIRO, 2008).

Segundo rege o Decreto n 29.042/2001 (RIO DE JANEIRO, 2001),

Art. 1 Fica instituído o "Programa de Incentivo do Governo do Estado à Produção de Leite", mediante a concessão de crédito presumido do ICMS ao contribuinte fluminense que adquirir leite produzido no Estado do Rio de Janeiro, diretamente do produtor ou através de usinas de laticínios legalmente estabelecidas neste Estado, correspondente ao percentual de $12,28 \%$ (doze inteiros e vinte e oito décimos por cento), sobre o valor total dessas compras, realizadas a partir de 01 de janeiro de 2002.

No Decreto no 46.198/2017 (RIO DE JANEIRO, 2017):

Art. 10. O estabelecimento industrial poderá creditar-se do valor correspondente ao ICMS incidente nas operações em que promover a saída de produto industrializado derivado de leite, inclusive leite UHT Longa Vida comercializado em caixa, destinado ao contribuinte do imposto, vedado o aproveitamento de quaisquer outros créditos de ICMS, inclusive os referidos nos artigos $1 .{ }^{\circ}, 3 .{ }^{\circ}$ e $4 .{ }^{\circ}$.

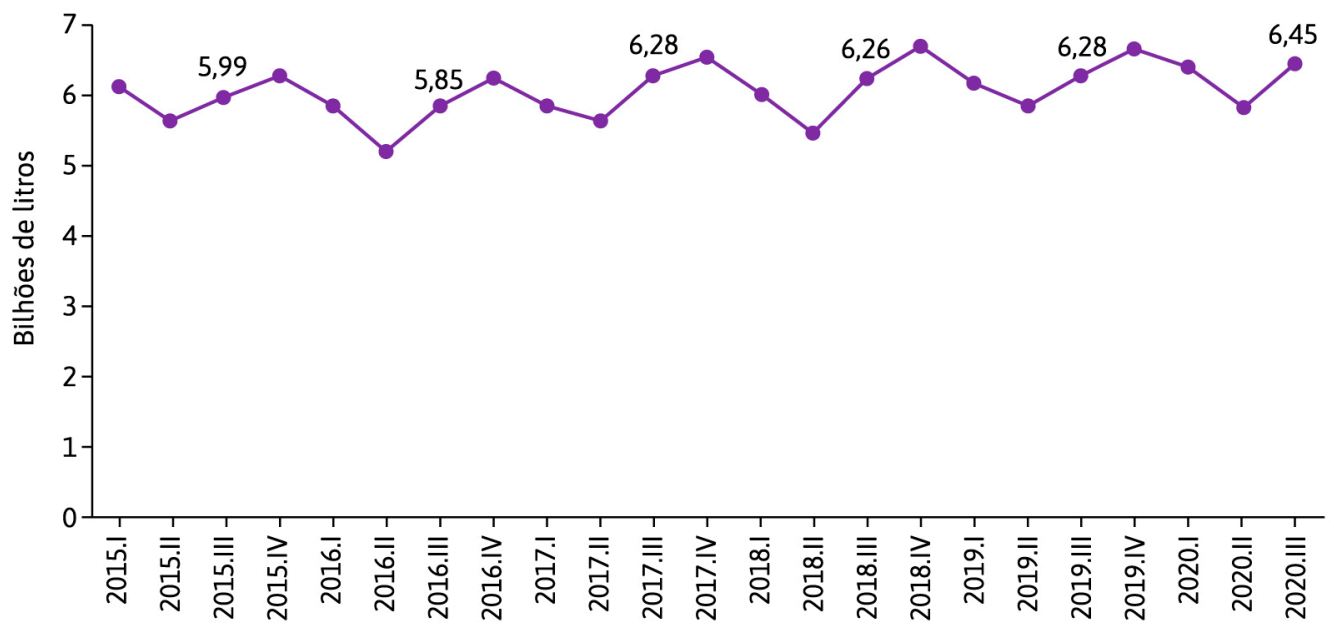

Figura 1 - Aquisição de leite cru por trimestre no Brasil de 2015 a 2020.

Fonte: Estatística da Pecuária do Instituto Brasileiro de Geografia e Estatística (2020). 
$\$ 7 .^{\circ} \mathrm{O}$ crédito de que trata o caput deste artigo somente se aplica quando se tratar de saída de produto lácteo industrializado no Estado do Rio de Janeiro, ainda que a matéria-prima ou insumos utilizados para sua fabricação sejam provenientes de outras unidades federadas, inclusive leite in natura, cru, resfriado ou pasteurizado, transportado a granel.

Em termos de subsídios destinados ao fomento da produção leiteira, a Tabela 1 traz um panorama dos recursos concedidos em valores absolutos deflacionados, por regiões de governo, entre 2007 e 2016, com algumas lacunas em razão da falta de dados nos períodos de 2010 e 2011, segundo a LOAS/RJ.

Entre 2007 e 2016, os recursos aprovados na Lei Orçamentária Anual (LOA) do estado do Rio de Janeiro aumentaram significativamente, e as regiões Médio Paraíba e Noroeste Fluminense passaram a liderar nos valores liberados. $\mathrm{O}$ acumulado nesse período mostra (Figura 2) que o Médio Paraíba recebeu subsídios de R\$ 270 milhões, seguida pelo Noroeste Fluminense, com aproximadamente R 212 milhões, por serem as principais regiões produtoras de leite do estado do Rio de Janeiro (MADANÊLO;

Tabela 1 - Subsídios do estado do Rio de Janeiro para o incentivo à produção de leite, em números absolutos (R\$ milhões) deflacionados, nas regiões de governo.

\begin{tabular}{|lllllllll} 
Região & $\mathbf{2 0 0 7}$ & $\mathbf{2 0 0 8}$ & $\mathbf{2 0 0 9}$ & $\mathbf{2 0 1 2}$ & $\mathbf{2 0 1 3}$ & $\mathbf{2 0 1 4}$ & $\mathbf{2 0 1 5}$ & $\mathbf{2 0 1 6}$ \\
\hline Baixadas Litorâneas & 2,0 & 1,9 & 8,3 & 0,0 & 0,0 & 0,0 & 5,5 & 1,8 \\
\hline Centro-Sul Fluminense & 2,7 & 2,6 & 2,3 & 0,2 & 3,8 & 14,0 & 38,9 & 45,3 \\
\hline Médio Paraíba & 6,6 & 8,4 & 5,1 & 16,0 & 38,6 & 55,8 & 80,1 & 59,2 \\
\hline Metropolitana & 1,3 & 1,1 & 0,0 & 12,8 & 6,0 & 7,3 & 21,4 & 1,4 \\
\hline Noroeste Fluminense & 6,8 & 8,5 & 8,5 & 29,0 & 0,7 & 0,0 & 82,5 & 75,5 \\
\hline Norte Fluminense & 3,7 & 4,9 & 5,3 & 0,7 & 24,8 & 2,4 & 9,0 & 0,0 \\
\hline Região Costa Verde & 0,0 & 0,1 & 1,1 & 0,1 & 0,0 & 0,1 & 0,0 & 0,0 \\
\hline Região Serrana & 3,8 & 4,4 & 2,1 & 13,3 & 24,5 & 5,9 & 43,0 & 37,9 \\
\hline Total & $\mathbf{2 6 , 9}$ & $\mathbf{3 1 , 9}$ & $\mathbf{3 2 , 7}$ & $\mathbf{7 2 , 1}$ & $\mathbf{9 8 , 4}$ & $\mathbf{8 5 , 5}$ & $\mathbf{2 8 0 , 5}$ & $\mathbf{2 2 1 , 2}$
\end{tabular}

Fonte: SEFAZ.

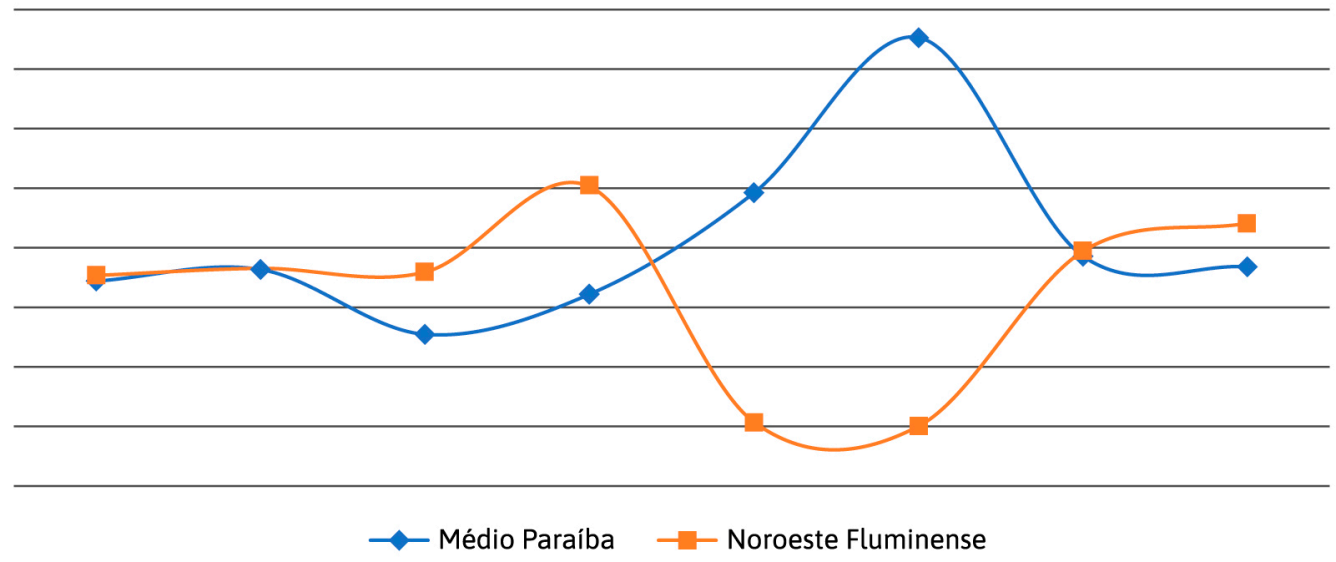

Figura 2 - Subsídios do estado do Rio de Janeiro para o incentivo à produção de leite, em percentuais, nas regiões Médio Paraíba e Noroeste Fluminense. Fonte: SEFAZ. 
MARAFON, 2008, p. 11). Na região Médio Paraíba, está situada a maior cooperativa de leite do estado, a Cooperativa Agropecuária Barra Mansa, com "uma média de 120 mil litros por dia de aproximadamente 1000 associados, dos quais $80 \%$ são pequenos produtores", e uma parte é destinada a Nestlé. Já a região Noroeste Fluminense conta com a segunda maior cooperativa, a Cooperativa Agropecuária de Itaperuna (CAPIL) (MADANÊLO; MARAFON, 2008, p. 11).

Em termos de variação da produção leiteira nos 20 principais municípios fluminenses produtores de leite entre 2010 e 2019, a Tabela 2 e a Figura 3 mostram dois comportamentos opostos: de um lado, a variação positiva em seis municípios, sendo dois da região Noroeste Fluminense (Cambuci e Bom Jesus de Itabapoana); do outro lado, 14 municípios tiveram redução da produção, sendo Itaperuna e Vassouras com maiores variações negativas. A região Noroeste Fluminense, em linhas gerais, é uma bacia leiteira e vem passando por um processo de reorganização produtiva, sendo lócus de ações de instituições públicas e organizações coletivas, algo que será abordado nas seções posteriores.

Tabela 2 - Principais municípios fluminenses com produção da pecuária leiteira, 2010 e 2019, com variação (\%).

\begin{tabular}{lccc}
\hline Municípios & \multicolumn{3}{c}{ Produção de leite (mil litros) } \\
& 2010 & 2019 & Variação (\%) \\
\hline Resende & 18.000 & 30.057 & 66,98 \\
\hline São Francisco de Itabapoana & 10.385 & 16.386 & 57,79 \\
\hline Campos dos Goytacazes & 22.352 & 33.477 & 49,77 \\
\hline Cambuci & 10.700 & 14.890 & 39,16 \\
\hline Bom Jesus do Itabapoana & 15.470 & 16.650 & 7,63 \\
\hline Rio Claro & 12.016 & 12.487 & 3,92 \\
\hline Carmo & 9.244 & 8.953 & $-3,15$ \\
\hline Barra Mansa & 23.106 & 21.857 & $-5,41$ \\
\hline Cantagalo & 16.037 & 14.125 & $-11,92$ \\
\hline Valença & 29.522 & 25.176 & $-14,72$ \\
\hline Santo Antônio de Pádua & 13.948 & 10.508 & $-24,66$ \\
\hline Rio das Flores & 9.914 & 7.411 & $-25,25$ \\
\hline Itaocara & 14.306 & 9.768 & $-31,72$ \\
\hline Natividade & 9.390 & 6.015 & $-35,94$ \\
\hline São Fidélis & 17.840 & 11.020 & $-38,23$ \\
\hline Cachoeiras de Macacu & 7.340 & 4.309 & $-41,29$ \\
\hline Barra do Piraí & 13.982 & 8.157 & $-41,66$ \\
\hline Santa Maria Madalena & 8.926 & 4.865 & $-45,50$ \\
\hline Itaperuna & 28.920 & 13.494 & $-53,34$ \\
\hline Vassouras & 16.238 & 5.960 & $-63,30$ \\
\hline Pan & & & \\
\hline
\end{tabular}

Fonte: Pesquisa Pecuária Municipal (2010 e 2019). 


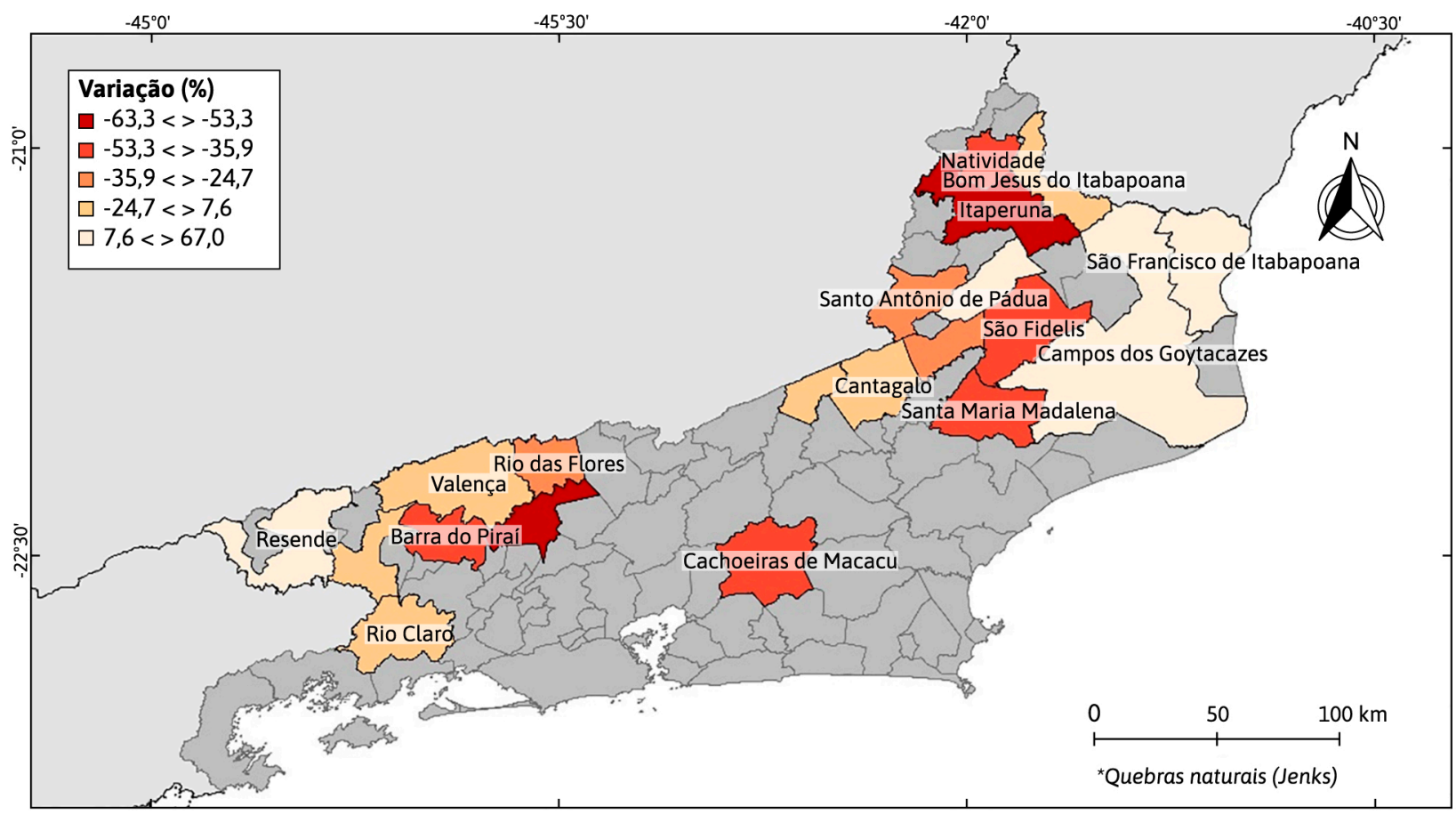

Relação entre a produção de leite (mil litros) de 2010 e de 2019 - 20 maiores produtores do Estado do Rio de Janeiro

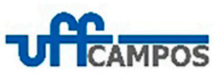

Sistema de coordenadas geográficas Datum SIRGAS2000

Base cartográfica: IBGE, 2019

Fonte: Sistema IBGE de Recuperação Automática

Elaboração: Marco Túlio Moraes Velasque Silva

Figura 3 - A variação da produção de leite (mil litros) nos 20 principais municípios fluminenses produtores (2010-2019).

Fonte: Instituto Brasileiro de Geografia e Estatística (2019).

\section{A região Noroeste Fluminense}

A região Noroeste Fluminense (Figura 4) abarca territorialmente 13 municípios (Aperibé, Cambuci, Italva, Itaperuna, Bom Jesus do Itabapoana, Itaocara, Santo Antônio de Pádua, Varre-Sai, Porciúncula, Natividade, São José de Ubá, Miracema e Laje do Muriaé) e possui uma área de $5.374 \mathrm{Km}^{2}$ (INSTITUTO BRASILEIRO DE GEOGRAFIA E ESTATÍSTICA, 2018).

A cafeicultura era, até os anos 1940, a principal atividade agrícola (GRABOIS et al., 1998; SILVA, 1997, 2006; CRUZ, 1997; 2007; MARINHO, 2017). Diante da crise da atividade, da emergência de novas áreas produtoras mais competitivas e do arrefecimento nas exportações, a cafeicultura foi sendo substituída pela pecuária leiteira. Essas mudanças produtivas refletiram também na estrutura fundiária e na mão de obra, pois, enquanto o café demandava cuidado intensivo, grandes quantitativos de mão de obra (familiar e temporário) e ocupava as pequenas propriedades, a pecuária, em contraposição, era uma atividade extensiva, que não demandava uma participação significativa de mão de obra e abarcava, sobretudo, médias e grandes propriedades (GRABOIS et al., 1998).

Nos anos 1960, segundo Silva (2006, p. 97), a região Noroeste Fluminense "beneficiou-se modestamente dos capitais agroindustriais implementados no território nacional em 


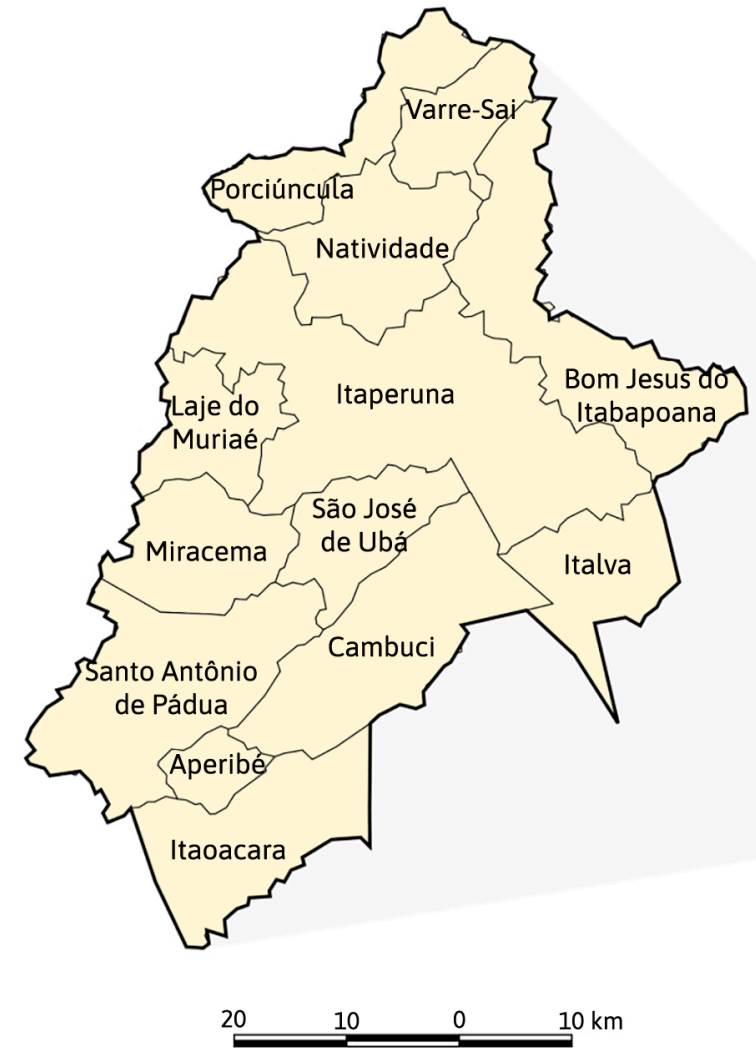

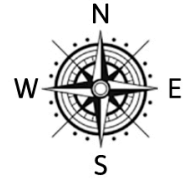

$\mathrm{S}$

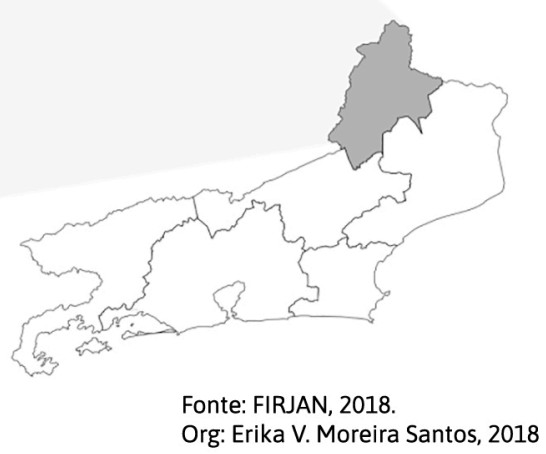

Figura 4 - Localização dos municípios da região Noroeste Fluminense. Fonte: Sistema Firjan (2015).

atendimento à demanda de um mercado urbano fortalecido tanto no Brasil quanto no exterior". No ano de 1961, houve, segundo o autor, a articulação entre a Leite Glória e a Fleischmann \& Royal, e tal estratégia “[...] projetou o Noroeste além dos seus limites político-administrativos, cunhando-se, no imaginário da população fluminense, a identificação emblemática: Noroeste Fluminense: tradicional região leiteira" (SILVA, 2006, p. 97). No final dos anos 1980 e início dos anos 1990, a região passou por crise no setor leiteiro por conta da competitividade com outras bacias leiteiras e da própria estagnação econômica que o país enfrentava naquele contexto.

Segundo Cruz (2007, p. 1), a região Noroeste Fluminense foi "criada em 1987 pelo desmembramento da região Norte Fluminense e na busca de uma 'independência' com relação a Campos dos Goytacazes, que monopolizava a atenção e os recursos da iniciativa privada e dos governos estadual e federal". No final dos anos 1990, foi institucionalizada a regionalização do estado do Rio de Janeiro, pautada nas equivocadas "vocações", sendo o Noroeste Fluminense classificado dentro da vocação para o complexo agropecuário representado por culturas modernas destinadas à exportação ou às indústrias processadoras de alimentos, principalmente nos setores de carne, leite, frutas e leguminosas (MARINHO, 2017, p. 12).

O processo de êxodo rural na região Noroeste Fluminense foi intensificado com a crise da cafeicultura nos anos 1960/70, levando à saída da população rural para o mercado 
de trabalho urbano nas principais cidades da região - Itaperuna e Santo Antônio de Pádua -, pois a produção de café era intensiva em mão de obra (GRABOIS et al., 1998). A população rural, nos últimos anos, reduziu em quase $50 \%$, ao passo que a população urbana aumentou consideravelmente (Tabela 3). Contudo, nos municípios de São José de Ubá e Laje do Muriaé, o fenômeno que vem acontecendo é o de esvaziamento populacional, ou seja, a saída tanto da população rural quanto urbana para outros municípios.

No tocante à estrutura fundiária, a maioria dos municípios teve ampliação tanto do número de estabelecimentos agropecuários quanto da área ocupada, com destaque para Itaperuna e São José de Ubá. Em contrapartida, houve redução de número de estabelecimentos e da área ocupada em Laje do Muriaé. Apenas Natividade teve um movimento de redução da área ocupada, mas uma ampliação significativa de estabelecimentos.

A pecuária está presente majoritariamente nos estabelecimentos familiares, todavia deve-se considerar a relação do tamanho da área com o número de animais, pois há uma relação desigual nesse quesito. Em termos de número de estabelecimentos, a Tabela 4 retrata o peso significativo de estabelecimentos agropecuários com o desenvolvimento da pecuária, destacando-se Itaocara, Itaperuna e Italva. A pecuária leiteira é uma estratégia de reprodução econômica e social dos agricultores familiares e também um desafio diante das questões políticas e econômicas em que o Noroeste Fluminense está inserido, especialmente a desarticulação de organizações coletivas, a subordinação de empresas de processamento e os reduzidos recursos para fomentar a atividade leiteira junto à agricultura familiar.

Tabela 3 - Dinâmica populacional dos municípios da região Noroeste Fluminense, entre 1991 e 2010, segundo a situação de domicílio.

\begin{tabular}{|lcccccc|}
\hline Municípios & \multicolumn{2}{c}{1991} & \multicolumn{2}{c}{2000} & \multicolumn{2}{c}{2010} \\
& Rural & Urbana & Rural & Urbana & Rural & Urbana \\
\hline Aperibé & & & 1.176 & 6.842 & 1.335 & 8.878 \\
\hline Bom Jesus do Itabapoana & 8.693 & 21.180 & 6.230 & 27.425 & 5.484 & 29.927 \\
\hline Cambuci & 11.649 & 9.362 & 4.724 & 9.946 & 3.535 & 11.292 \\
\hline Italva & 6.412 & 6.352 & 4.010 & 8.611 & 3.821 & 10.242 \\
\hline Itaocara & 9.439 & 13.494 & 7.075 & 15.928 & 5.573 & 17.326 \\
\hline Itaperuna & 16.258 & 61.742 & 9.856 & 76.864 & 7.743 & 88.368 \\
\hline Laje do Muriaé & 3.660 & 3.804 & 2.285 & 5.624 & 1.850 & 5.637 \\
\hline Miracema & 4.137 & 20.954 & 3.307 & 23.757 & 2.102 & 24.741 \\
\hline Natividade & 9.629 & 12.136 & 3.384 & 11.741 & 3.036 & 12.046 \\
\hline Porciúncula & 5.026 & 9.535 & 4.075 & 12.018 & 3.870 & 13.890 \\
\hline Santo Antonio de Pádua & 28.025 & 11.575 & 9.277 & 29.415 & 9.489 & 31.100 \\
\hline São José de Ubá & & & 4.087 & 2.326 & 3.905 & 3.098 \\
\hline Varre-Sai & & & 3.722 & 4.132 & 3.685 & 5.790 \\
\hline Total & 102.298 & 170.134 & 63.208 & 234.629 & 55.428 & 262.335 \\
\hline
\end{tabular}

Fonte: IBGE (Censos 1991, 2000 e 2010). 
Tabela 4 - Estabelecimentos agropecuários (familiar e não familiar) com desenvolvimento da pecuária, em 2017, nos municípios da região Noroeste Fluminense.

\begin{tabular}{|lcc|}
\hline Municípios & 2017 & \\
& No estab não familiar & $\mathbf{N}^{\circ}$ estab familiar \\
\hline Aperibé & 75 & 178 \\
\hline Bom Jesus do Itabapoana & 387 & 568 \\
\hline Cambuci & 288 & 765 \\
\hline Italva & 124 & 275 \\
\hline Itaperuna & 610 & 929 \\
\hline Itaocara & 351 & 975 \\
\hline Laje do Muriaé & 103 & 228 \\
\hline Miracema & 209 & 164 \\
\hline Natividade & 240 & 397 \\
\hline São José do Ubá & 194 & 316 \\
\hline Santo Antonio de Pádua & 402 & 659 \\
\hline Porciúncula & 123 & 294 \\
\hline Varre-Sai & 106 & 227 \\
\hline
\end{tabular}

Fonte: Censo Agropecuário (2017).

\section{A atividade leiteira no Noroeste Fluminense}

Para subsidiar nossa análise sobre a atividade leiteira no Noroeste Fluminense, tomamos como base Silva (2006), Grabois et al. (1998), Madanêlo e Marafon (2008), Braga (2008) e Santos (2019). Esse percurso teórico permite compreender como a região vem sendo reorganizada produtivamente a partir de estratégias espaciais de agentes econômicos e políticos.

Desde a década de 1960, a região Noroeste Fluminense tem apresentado certa expressividade na pecuária leiteira. Em 1976, a Fleischmann \& Royal passou a deter o controle acionário da agroindústria local, gerenciando, diretamente, o beneficiamento da produção regional de leite (SILVA, 1997, p. 59), o que levou a Cooperativa Agropecuária de Itaperuna (CAPIL) a exigir de seus associados um "aumento da qualidade da matéria-prima a ser beneficiada. Sob essa nova dinâmica regional, a cooperativa incentivou os seus cooperados a entrarem nas linhas de crédito agrícola", com o objetivo de aumentar a produtividade (SILVA, 1997, p. 59). Madanêlo e Marafon (2008, p.13) apontam que a CAPIL ficou subordinada à Parmalat a partir de 2001, "pondo fim à gestão da Kraft Foods International" 2 . Em 2003, a Parmalat apresentou problemas financeiros, o que levou à "consequente desestabilização da cooperativa e de seus 1.250 associados do Noroeste do estado". Isso resultou em uma crise para a CAPIL e para os produtores de leite, em sua maioria de pequeno porte e com base na mão de obra familiar (MADANÊLO; MARAFON, 2008).

Dos 13 municípios do Noroeste Fluminense, apenas quatro - Varre-Sai, Cambuci, Aperibé e Bom Jesus do Itabapoana - apresentam variação positiva da produção de leite no período de 2010 e 2019, como mostra a Tabela 5 e a Figura 5. E os principais

\footnotetext{
${ }^{2}$ Para maiores detalhamento dessa gestão territorial, ver trabalhos de Silva (2006) e Braga (2008).
} 
Tabela 5 - Variação da produção de leite (mil litros) nos municípios da região Noroeste Fluminense, 2010 e 2019

\begin{tabular}{|lccc|}
\hline Municípios & \multicolumn{3}{c|}{ Produção de leite (mil litros) } \\
& $\mathbf{2 0 1 0}$ & $\mathbf{2 0 1 9}$ & Variação (\%) \\
\hline Varre-Sai & 3.710 & 6.910 & 86,25 \\
\hline Cambuci & 10.700 & 14.890 & 39,16 \\
\hline Aperibé & 2.222 & 2.600 & 17,01 \\
\hline Bom Jesus do Itabapoana & 15.470 & 16.650 & 7,63 \\
\hline Laje do Muriaé & 4.418 & 4.022 & $-8,96$ \\
\hline Italva & 5.750 & 4.804 & $-16,45$ \\
\hline Miracema & 6.935 & 5.497 & $-20,74$ \\
\hline Santo Antonio de Pádua & 13.948 & 10.508 & $-24,66$ \\
\hline Itaocara & 14.306 & 9.768 & $-31,72$ \\
\hline Porciúncula & 7.954 & 5.300 & $-33,37$ \\
\hline Natividade & 9.390 & 6.015 & $-35,94$ \\
\hline São José do Ubá & 10.250 & 5.500 & $-46,34$ \\
\hline Itaperuna & 28.920 & 13.494 & $-53,34$ \\
\hline
\end{tabular}

Fonte: Produção Pecuária Municipal (2010 e 2019).

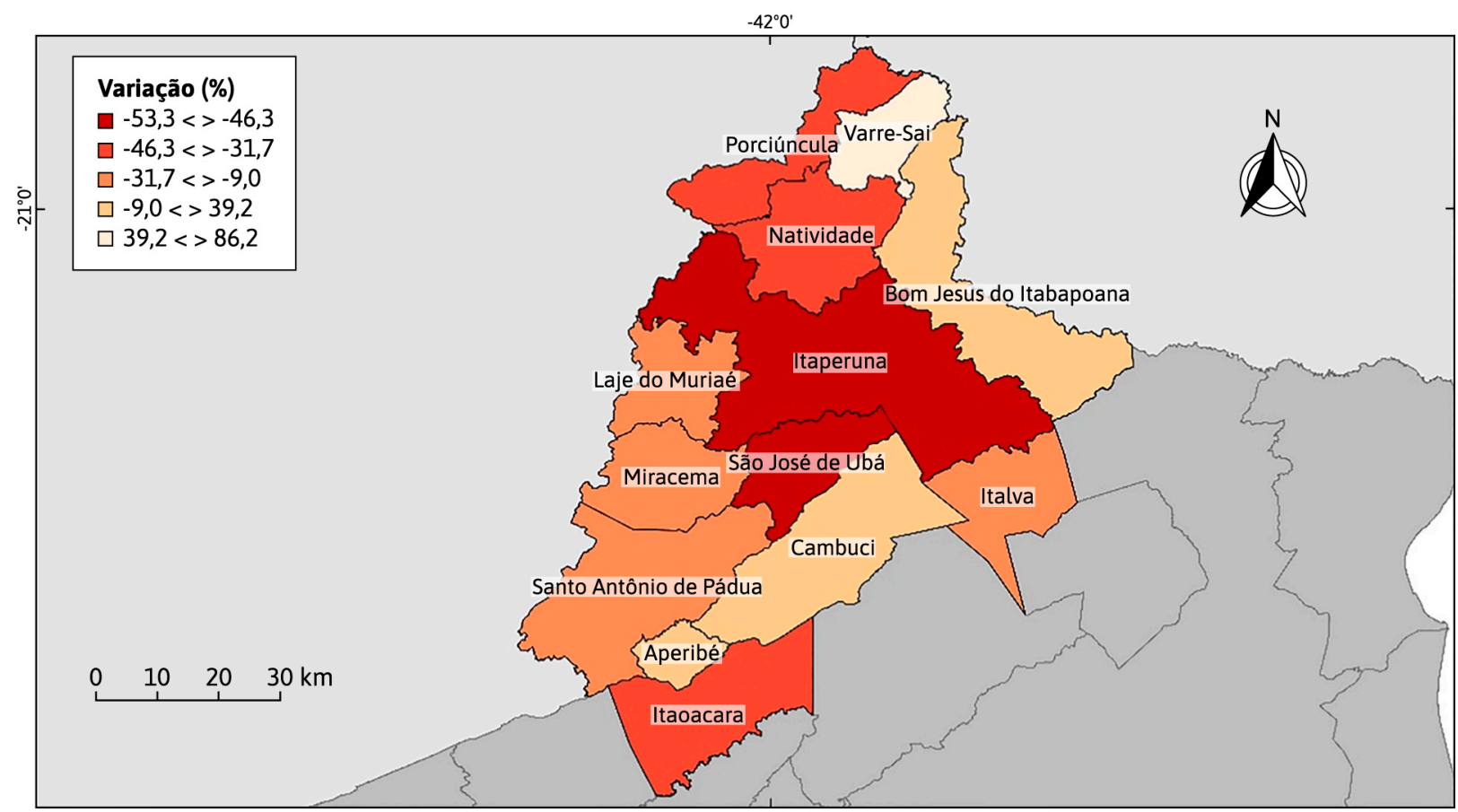

Relação entre a produção de leite (mil litros) de 2010 e de 2019 - 20 maiores produtores do Estado do Rio de Janeiro

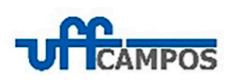

\section{Sistema de coordenadas geográficas Datum SIRGAS2000 \\ Base cartográfica: IBGE, 2019}

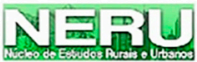

Fonte: Sistema IBGE de Recuperação Automática

Elaboração: Marco Túlio Moraes Velasque Silva

Figura 5 - Variação da produção de leite (mil litros) nos municípios da região Noroeste Fluminense, 2010 e 2019.

Fonte: Produção Pecuária Municipal. 
Tabela 6 - Número de estabelecimentos agropecuários que produzem derivados lácteos internamente, nos municípios da região Noroeste Fluminense, 2006 e 2017.

\begin{tabular}{|lcc|}
\hline Município & $\mathbf{2 0 0 6}$ & $\mathbf{2 0 1 7}$ \\
& $\mathbf{N}^{\circ}$ de estab. & $\mathbf{N}^{\circ}$ de estab. \\
\hline Aperibé & 0 & 4 \\
\hline Bom Jesus do Itabapoana & 3 & 15 \\
\hline Cambuci & 2 & 13 \\
\hline Italva & 0 & 8 \\
\hline Itaperuna & 2 & 43 \\
\hline Itaocara & 16 & 44 \\
\hline Laje do Muriaé & 1 & 13 \\
\hline Miracema & 4 & 9 \\
\hline Natividade & 3 & 14 \\
\hline São José do Ubá & 1 & 4 \\
\hline Santo Antonio de Pádua & 3 & 26 \\
\hline Porciúncula & 7 & 22 \\
\hline Varre-Sai & 12 & 4 \\
\hline Total & 54 & 219 \\
\hline
\end{tabular}

Fonte: IBGE (Censos agropecuários de 2006 e 2017).

municípios que se destacam como os maiores produtores de leite são Itaperuna, Bom Jesus de Itabapoana, Cambuci e Santo Antônio de Pádua.

No Censo Agropecuário de 2006, a região possuía 54 estabelecimentos rurais, que, além da produção do leite cru, também produziam manteiga, queijos e requeijão. Já o Censo Agropecuário de 2017 apontou um aumento para 219 estabelecimentos (Tabela 6). A relação das agroindústrias e os agricultores familiares está pautada em dois vetores importantes (GAZOLLA, 2017, p. 187): 1) relações sociais de proximidade, interconhecimento e relações de confiança; e 2) "presença de economia de escopo na viabilização das agroindústria". As agroindústrias familiares de lácteos são formas de estratégias econômicas e sociais. Esse incremento significativo é resultado de políticas públicas (Pronaf, Balde Cheio, Rio Rural, Decretos de Incentivos à Produção de Leite no estado do Rio de Janeiro, Lei de Isenção do ICMS etc.) e estratégia importante para geração de renda e trabalho diante da crise ocasionada pela falência da Parmalat.

\section{Políticas públicas, instituições e atividade leiteira no Noroeste Fluminense}

A discussão sobre a agricultura familiar vem ganhando legitimidade social, política e acadêmica no Brasil, passando a ser utilizada com mais frequência nos movimentos sociais rurais, pelos órgãos governamentais e por pesquisadores (SCHNEIDER, 2003, p. 99). O agricultor familiar é, sem dúvida, um ator social do mundo moderno, construtor e parceiro de um projeto de sociedade, e não simplesmente objeto de intervenção do Estado, sem história (WANDERLEY, 2004, p. 47). 
Neste contexto, é interessante compreender o espaço rural do Noroeste Fluminense não apenas como um espaço físico de desenvolvimento das atividades agropecuárias, mas à luz da importância da agricultura familiar.

A bovinocultura de leite é um segmento relevante para o desenvolvimento econômico de diversas regiões brasileiras, pois permite a geração de renda e trabalho, reduzindo as pressões sociais e minimizando o desemprego e as questões sociais (EURICH et al., 2016, p. 455).

No Noroeste Fluminense, a bovinocultura de leite recebe apoio de instituições de pesquisa, fomento, capacitação e assistência técnica - como a Empresa de Pesquisa Agropecuária do Estado do Rio de Janeiro (PESAGRO-Rio), o SENAR e a EMATER-Rio e constitui uma atividade imprescindível, atuando na construção de uma economia mais produtiva e socialmente mais justa. Como exemplo, há o Balde Cheio e o Rio Rural, que são políticas públicas vinculadas à estrutura produtiva fluminense.

O projeto "Balde Cheio" coordenado pela Embrapa Pecuária Sudeste, tem como objetivo a transferência de um pacote de conhecimentos e tecnologias para o pequeno produtor de leite e sua capacidade de funcionar como vetor de promoção do desenvolvimento sustentável do agronegócio do leite, compatibilizando a produção local às tendências de produção sustentável em curso no setor internacionalmente (BORGES et al., 2011, p. 152).

Uma das principais estratégias do Balde Cheio são as parcerias firmadas com entidades públicas e privadas, diminuindo a distância entre os institutos de pesquisa e os produtores (EMPRESA BRASILEIRA DE PESQUISA AGROPECUÁRIA, 2008). Além disso, a troca de informações sempre acontece na propriedade rural, na chamada de Unidade Demonstrativa (UD).

Para Schmitz e Santos (2013), a produção leiteira aumenta quando estimulada por políticas públicas, pois objetiva a melhoria na qualidade do leite, padronização essa exigida também pelo setor lácteo (SCHMITZ; SANTOS, 2013, p. 344).

Essas parcerias são importantes, pois, segundo o entrevistado 1, a qualidade do leite é, sem dúvida, a maior dificuldade enfrentada no processamento de lácteos no Noroeste Fluminense. Além disso, existem problemas estruturais que afetam direta e indiretamente produtores e indústrias, tais como: dificuldades de acesso à propriedade por meio de estradas vicinais, deficiência de energia elétrica, questões tributárias, preço do concentrado, questão climática atingindo a produtividade e a qualidade do leite.

Deste modo, uma logística estruturada favoreceria a ampliação da produção, permitindo, inclusive, que a agricultura familiar e a cadeia produtiva do leite ganhassem em competitividade tanto nos principais mercados do estado do Rio de Janeiro quanto na própria região Sudeste.

Já a EMATER-Rio contribui de forma social, assessorando e promovendo a garantia de direitos aos diversos públicos do meio rural e suas organizações por meio da assistência técnica e extensão rural social gratuita (EMPRESA DE ASSISTÊNCIA TÉCNICA E EXTENSÃO RURAL DO ESTADO DO RIO DE JANEIRO, 2021).

Por sua vez, o Programa de Desenvolvimento Rural Sustentável em Microbacias Hidrográficas (Rio Rural) é uma das políticas públicas do Governo do Estado do Rio de Janeiro para o meio rural (RIO RURAL, 2009). De acordo com as considerações de Marinho (2015, p. 79), o Programa abarcou duas etapas: "a primeira denominada Rio 
Rural/GEF - Projeto Gerenciamento Integrado de Agroecossistemas em Microbacias Hidrográficas do Norte e Noroeste Fluminense; e a segunda denominada Rio Rural/BIRD - Projeto de Desenvolvimento Rural Sustentável em Microbacias Hidrográficas do Estado do Rio de Janeiro".

Segundo o entrevistado 2, da EMATER, no município de Italva, localizado no Noroeste Fluminense, foram aplicados $\mathrm{R} \$ 6.260 .000,00$, oriundos do Programa Rio Rural na dimensão ambiental, social e econômica. Isso permitiu que quase 300 hectares de áreas fossem protegidos, georreferenciados e cercados e que todas as associações possuíssem sede própria, trator e arado.

No trabalho Souza et al. (2014), foram avaliados os sistemas de produção organizados em microbacias hidrográficas nos municípios de Itaperuna, Itaocara e Italva. Os resultados mostram uma agropecuária tradicional, em que vários fatores limitaram a eficiência do sistema de produção de leite nas propriedades selecionadas, como manejo alimentar, baixa qualidade do rebanho e das condições tecnológicas.

Para fomentar a bovinocultura, em particular a de leite, o estado buscou implementar, articulado com as esferas federais e municipais, ações estratégicas, programas e políticas públicas. Por exemplo, a Lei no $2.726 / 17$ isenta os setores de laticínios, agroindústria artesanal (até 20 empregados e faturamento anual de até R $\$ 110$ mil UFIRS/RJ), hortifrutigranjeiros e agricultura familiar do recolhimento de 10\% do Fundo Estadual de Equilíbrio Fiscal (FEEF).

Outro programa foi o Prosperar, que buscou ampliar a oferta de emprego e a geração de renda na área rural, apoiando as agroindústrias com a atuação e assistência da EMATER-Rio. Segundo o relatório de atividades da instituição no ano de 2019, as principais ações do Programa tiveram como base legislações sanitárias (Resolução SEAAPI no 510 e n 17 , Resolução SES no 1.779 e Lei $n^{\circ} 4.177$ ), que são mais adequadas a pequenas agroindústrias (EMPRESA DE ASSISTÊNCIA TÉCNICA E EXTENSÃO RURAL DO ESTADO DO RIO DE JANEIRO, 2019).

Por isso, a aplicação de políticas públicas eficientes e a utilização de assistência técnica por parte dos agricultores, contando com a participação deles em cooperativas rurais, levam à geração de renda local.

Todavia, mesmo com essas políticas públicas implementadas, o Noroeste Fluminense é marcado pela concentração de terras e pela desigualdade no acesso aos recursos técnicos e financeiros, sobretudo vinculados à agricultura familiar.

\section{Considerações finais}

A atividade leiteira no Noroeste Fluminense vem sendo uma estratégia de reprodução econômica desde a década de 1960, com a atuação de organizações coletivas e empresas. Não obstante, a atividade tem sido marcada pela desigualdade no acesso aos recursos financeiros e técnicos. Neste trabalho, as inquietações remeteram a entender as questões atinentes ao papel do estado no fomento às ações e políticas para o setor leiteiro da agricultura familiar.

O papel das instituições e entidades é importante para a implementação de políticas públicas de fomento à atividade leiteira, como é o caso da EMATER-Rio, para os projetos de bovinocultura leiteira, Prosperar, Rio Rural e SENAR-Rio, na implementação do 
projeto Balde Cheio. Os escassos recursos financeiros e humanos levam ao esvaziamento das políticas públicas e a um grande desafio para os agricultores familiares, sobretudo em uma região marcada pela concentração fundiária e a redução da população rural.

Se, outrora, a atividade cafeeira foi sendo substituída pela pecuária leiteira, atualmente o agroprocessamento de derivados lácteos vem sendo uma estratégia de geração de renda e trabalho nos estabelecimentos agropecuários familiares, porém carece de mais fomento para sua consolidação.

\section{Referências}

BORGES, M. S.; GUEDES, C. A. M.; ASSIS, R. L. Um estudo do "projeto Balde Cheio" como vetor do desenvolvimento sustentável do pequeno produtor de leite. Revista Brasileira de Agropecuária Sustentável, Viçosa, v. 1, p. 151-161, 2011.

BRAGA, R. M. Gestão do território: o caso da empresa Glória em Itaperuna-RJ (1960-2003). In: MARAFON, G. J.; RIBEIRO, M. A. (Org.). Revisitando o Território Fluminense II. Rio de Janeiro: Gramma, 2008, p. 287-303.

BRASIL. Instrução normativa n 51. Regulamentação, técnica de produção, identificação, coleta e transporte. Diário Oficial da República Federativa do Brasil, Brasília, DF, 2002.

BRASIL. Portaria n ${ }^{\circ}$ 56. Programa Nacional de Qualidade do Leite. Diário Oficial da República Federativa do Brasil, Brasília, DF, 1999.

CAMILO, P. A. A dinâmica geoeconômica da comercialização, logística e transporteda cadeia produtiva do leite na região Sul do Brasil. 2018. Tese (Doutorado em Geografia)-Universidade Federal de Santa Catarina, Florianópolis, 2018.

CRUZ, J. L. V. Desenvolvimento do norte/noroeste fluminense: problematizando o consenso. Vértices, Campos dos Goitacazes, v. 1, n. 1, p. 28-36, 1997.

CRUZ, J. L. V. Os desafios do Norte e do Noroeste Fluminenses frente aos grandes projetos estratégicos. Vértices, Campos dos Goitacazes, v. 9, n. 1-3, p. 43-50, 2007.

EMPRESA BRASILEIRA DE PESQUISA AGROPECUÁRIA - EMBRAPA. Projeto Balde Cheio. São Carlos: Embrapa Pecuária Sudeste (CPPSE), 2008. Folder.

EMPRESA DE ASSISTÊNCIA TÉCNICA E EXTENSÃO RURAL DO ESTADO DO RIO DE JANEIRO EMATER-RIO. Atribuições. 2021. Disponível em: <http://www.emater.rj.gov.br/atribuições >. Acesso em: 25 jan. 2021.

EMPRESA DE ASSISTÊNCIA TÉCNICA E EXTENSÃO RURAL DO ESTADO DO RIO DE JANEIRO EMATER-RIO. Relatórios de atividades. 2019. Disponível em: <http://www.emater.rj.gov.br/relatório. asp>. Acesso em: 18 jan. 2021.

EURICH, J.; WEIRICH NETO, P. H.; ROCHA, C. H. Pecuária Leiteira em uma colônia de agricultores familiares no município de Palmeira Paraná. Revista Ceres, Viçosa, v. 63, n. 4, p. 454-460, 2016.

GAZOLLA, M. Cadeias curtas agroalimentares na agroindústria familiar: dinâmicas e atores envolvidos. In: GAZOLLA, M.; SCHNEIDER, S. (Org.). Cadeias curtas e redes agroalimentares alternativas: negócios e mercados da agricultura familiar. Porto Alegre: Editora UFRGS, 2017. p. 175-194.

GRABOIS, J. et al. O papel da pequena produção na organização de um espaço periférico: o caso do noroeste fluminense. In: CARNEIRO, M. J. et al. (Org.). Campo aberto, o rural no Estado do Rio de Janeiro. Rio de Janeiro: Contracapa, 1998. p. 209-222.

INSTITUTO BRASILEIRO DE GEOGRAFIA E ESTATÍSTICA - IBGE. Cidades. Rio de Janeiro: IBGE, 2018.

INSTITUTO BRASILEIRO DE GEOGRAFIA E ESTATÍSTICA - IBGE. Estatística da pecuária do Instituto Brasileiro de Geografia e Estatística. Rio de Janeiro: IBGE, 2020.

INSTITUTO BRASILEIRO DE GEOGRAFIA E ESTATÍSTICA - IBGE. Produção Pecuária Municipal (PPM). Rio de Janeiro: IBGE, 2010.

INSTITUTO BRASILEIRO DE GEOGRAFIA E ESTATÍSTICA - IBGE. Produção Pecuária Municipal (PPM). Rio de Janeiro: IBGE, 2019. 
MADANÊLO, D. H. V. L.; MARAFON, G. O complexo agroindústria da pecuária leiteira no Estado do Rio de Janeiro. In: MARAFON, G. J.; RIBEIRO, M. A. (Org.). Revisitando o Território Fluminense II. Rio de Janeiro: Gramma, 2008. p. 7-16.

MARINHO, I. A Região Noroeste Fluminense e o Projeto Rio Rural: tendências e problemas da agricultura familiar. 2015. Dissertação (Mestrado em Geografia)-Universidade Estadual do Rio de Janeiro, São Gonçalo, 2015.

MARINHO, I. Processo de regionalização do noroeste fluminense. Revista Tamoios, São Gonçalo, v. 13, n. 2, p. 78-93, 2017.

PRADO JUNIOR, C. Formação do Brasil contemporâneo. São Paulo: Cia das Letras, 2011.

RIO DE JANEIRO. Decreto no 29.042 de 27 de agosto de 2001. Dispõe sobre o incentivo do governo do estado à produção de leite. Diário Oficial do Estado do Rio de Janeiro, Rio de Janeiro, 28 ago. 2001.

RIO DE JANEIRO. Rio Rural. 2008. Disponível em: <http://www.microbacias.rj.gov.br/pt/microbacias>. Acesso em: jun. 2018.

RIO DE JANEIRO. Decreto n. 41.765 de 20 de março de 2009. Programa de Incentivo do Governo do Estado à Produção de Leite. Diário Oficial do Estado do Rio de Janeiro, Rio de Janeiro, 23 mar. 2009.

RIO DE JANEIRO. Decreto n. ${ }^{\circ} 46.198$ de 18 de dezembro de 2017. Altera o decreto estadual n. ${ }^{\circ} 29.042$, de 27 de agosto de 2001, que dispõe sobre o incentivo do governo do estado à produção de leite. Diário Oficial do Estado do Rio de Janeiro, Rio de Janeiro, 19 dez. 2017, p. 1.

RIO RURAL. Projeto Desenvolvimento Rural Sustentável. Secretaria de Agricultura, Pecuária, Pesca e Abastecimento/Superintendência de Desenvolvimento Sustentável, 2009. p. 99.

SANTOS, E. V. M. As agroindústrias de lácteos no noroeste fluminense: panorama e desafios. In: ENANPEGE, 13., São Paulo. Anais... São Paulo: ANPEGE, 2019.

SANTOS, J. C. O sistema agroindustrial do leite na região de Presidente Prudente-SP. 2004. $200 \mathrm{f}$. Dissertação (Mestrado em Geografia)-Universidade Estadual Paulista, Presidente Prudente, 2004.

SCHMITZ, A. M.; SANTOS, R. A. A. A produção de leite na agricultura familiar do Sudoeste do Paraná e a participação das mulheres no processo produtivo. Terra Plural, Ponta Grossa, v. 7, n. 2, p. 339-355, 2013.

SCHNEIDER, S. Teoria social, agricultura familiar e pluriatividade. Revista Brasileira de Ciências Sociais, São Paulo, v. 18, n. 51, p. 99-121, 2003.

SILVA, A. C. P. Gestão e território: o caso da empresa Fleischmann \& Royal no noroeste fluminense. Revista Campo-Território: Revista de Geografia Agrária, Uberlândia, v. 2, n. 2-3, p. 53-75, 1997.

SILVA, A. C. P. As estratégias de modernização do espaço rural fluminense: técnica, planejamento e gestão no campo do Rio de Janeiro. Campo-Território: Revista de Geografia Agrária, Uberlândia, v. 1, n. 2, p. 92-122, 2006.

SISTEMA FIRJAN. Retratos regionais da região Noroeste. 2015.

SOUZA, S. O. et al. Diagnóstico participativo das propriedades leiteiras visando à Implantação das unidades de pesquisa participativa de pastoreio rotacionado silvipastoris em microbacias hidrográficas da região Noroeste Fluminense. Projeto Rio Rural/GEF - Pesquisa participativa. PESAGRO-RIO, set. 2014. p. 1-7.

VALVERDE, O. Geografia da pecuária no Brasil. Finisterra Revista Portuguesa de Geografia, Lisboa, v. 2, n. 4, 1967. Disponível em: <http://revistas.rcaap.pt/ finisterra/article/view/2524/2152\#>. Acesso em: 18 dez. 2020.

WANDERLEY, M. N. B. Agricultura familiar e Campesinato: rupturas e continuidade. Revista de Economia e Sociologia Rural, Brasília, v. 11, n. 2, p. 47, 2004.

WILKINSON, J. O setor de lácteos no Brasil no contexto da globalização. In: LIMA, E. N.; DELGADO, N. G.; MOREIRA, R. J. Mundo rural: configurações rural-urbanas - poderes e políticas. Rio de Janeiro: MAUAD, 2007. p. 353-371. 
Erika Vanessa Moreira Santos. Graduada, mestre e doutora em Geografia pela Universidade Estadual Paulista Júlio de Mesquita Filho (UNESP). Atualmente, é docente da Universidade Federal Fluminense, atuando no Departamento de Geografia de Campos (GRC) e no Programa de PósGraduação em Geografia (PPG). É membro do Núcleo de Estudos Rurais e Urbanos (NERU). Tem experiência na área de Geografia, com ênfase nos seguintes temas: rural-urbana, ruralidade, agricultura familiar, bairros rurais, agricultura urbana e geografia e gênero.

Samara Venina Simen de Azeredo Silva Chagas. Doutora em Engenharia e Ciências dos Materiais pela Universidade Estadual do Norte Fluminense Darcy Ribeiro (UENF) (2016). Mestre em Engenharia e Ciências dos Materiais pela UENF (2011). Graduada em Ciências Biológicas em (2007) e Licenciatura em Geografia pela Universidade Estadual do Rio de Janeiro (UERJ) (2019). Atualmente, é mestranda no Programa de Pós-Graduação em Geografia da Universidade Federal Fluminense e desenvolve pesquisa intitulada "Programa Rio Rural no município de Italva-RJ”, fazendo parte do Núcleo de Estudos Rurais e Urbanos (NERU).

Marco Túlio Morais Velasque Silva. Graduando em Geografia (Bacharelado) pela Universidade Federal Fluminense, em Campos dos Goytacazes (UFF/ Campos). É membro do Núcleo de Estudos Rurais e Urbanos (NERU). Atualmente, é bolsista de iniciação científica da FAPERJ e desenvolve pesquisa sobre "O rural no noroeste fluminense no contexto da agricultura familiar no século XXI”. 


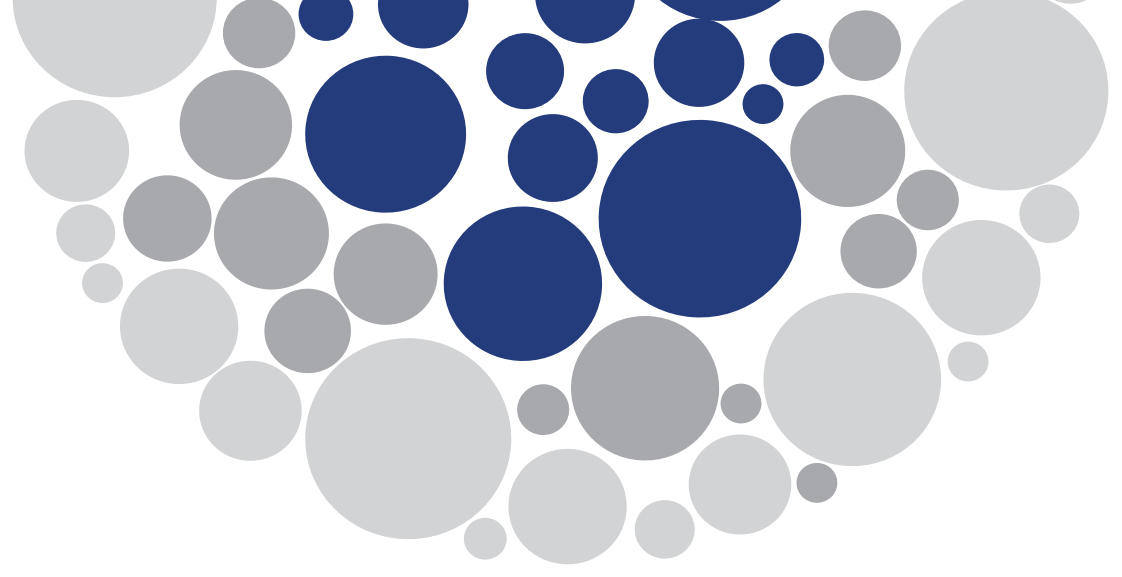

\title{
Explorando as teorias da firma na geografia econômica ${ }^{1}$
}

\author{
Leandro Bruno Santos ${ }^{a}$ \\ a Departamento de Geografia de Campos (GRC) e do Programa de Pós-Graduação em Geografia (PPG) da Universidade \\ Federal Fluminense. E-mail: leandrobruno@id.uff.br
}

\section{Introdução}

As ideias contidas neste texto se inserem em um conjunto de preocupações que emergiram durante a realização de tese de doutorado (SANTOS, 2012), em um diálogo - diga-se necessário - com as teorias da internacionalização de empresas propostas em outros campos disciplinares. Naquele momento, pudemos verificar que os estudos sobre as firmas eram marcados ora por abstrações voltadas à análise das dinâmicas gerais dos processos econômicos e suas inter-relações com o espaço, ora por abordagens pontuais de casos específicos. Verificamos ainda alguns esforços de maior fertilização cruzada, correndo os riscos de ecletismo, bem como iniciativas que promoviam contribuições no nível meso, criando nexos entre as dimensões macro e micro.

Todos os trabalhos convergiam no sentido de compreender as firmas como principais agentes responsáveis pela organização do sistema econômico e pela configuração da divisão territorial e internacional do trabalho. Nesse sentido, a compreensão dos seus papéis é fundamental para o estudo da organização dos complexos sistemas produtivos. As sucessivas temáticas de pesquisa na geografia econômica, ao longo do tempo, atestam essa preocupação com os estudos sobre as lógicas de localização industrial, o desenvolvimento regional, a reestruturação produtiva, as redes de produção global, os circuitos espaciais de produção e reprodução do capital etc.

\footnotetext{
1 Este texto é resultado de pesquisas em andamento com apoio do CNPq e da PROPPI/UFF.
} 
Maskell (2001), Taylor e Asheim (2001), Taylor (2006) e Dicken (2013) têm destacado, porém, a falta de preocupação quanto à definição e conceituação da firma, a sua excessiva categorização e a sua atomização em modelos causais abstratos. Nessa direção, Santos (2020) mostrou a forma ofuscada e ambígua da firma e sua cristalização atomística em uma causalidade de relações econômicas. Este texto parte dessas problemáticas e se propõe a explorar as diferentes abordagens sobre a firma na geografia econômica. Assim, o objetivo é analisar as principais perspectivas teóricas existentes sobre a firma e explorar as possibilidades de sua incorporação no campo da geografia econômica. Os procedimentos metodológicos se baseiam, principalmente, em um amplo levantamento e discussão de trabalhos acadêmicos que inserem a firma como objeto de teorização na Geografia.

O texto está estruturado, além desta introdução, em outras cinco partes. Na primeira, reunimos alguns elementos sobre a definição e a trajetória da geografia econômica, visando compreender suas sucessivas reorientações teórico-metodológicas e temáticas. Em seguida, analisamos a inserção da firma em cada um dos encaminhamentos teórico-metodológicos e sintetizamos as diversas abordagens existentes sobre a firma em outros campos disciplinares. Na terceira parte, discutimos quais teorias da firma exibem condições de serem incorporadas no métier da geografia econômica. Ao final, constam algumas considerações e as principais referências utilizadas.

\section{Definições e trajetórias da Geografia Econômica}

Apesar de parecer prosaico, não é demais salientar que qualquer aproximação a uma ciência, especialmente a um campo ou subárea do saber, requer que saibamos minimamente seus conteúdos temáticos prevalentes, o objeto de estudo (o que e por que estudar), os encaminhamentos teórico-metodológicos existentes (visões de mundo), as principais teorias (consolidadas, esquecidas/negligenciadas ou superadas), entre outros (SPOSITO, 2001). Um pequeno sobrevoo sobre a literatura especializada contendo as diferentes definições de geografia econômica atesta o quão vibrante tem sido essa disciplina desde sua sistematização no final do século XIX.

Lloyd e Dicken (1972, p. 2) ofereceram uma definição sintética e precisa que parece, ainda no contexto atual, assinalar o objeto de estudo da geografia econômica, ao afirmarem que a "[...] economic geography is concerned with the construction of general principles and theories that explain the operation of the economic system in space" (grifos dos autores). Claval (1980), citado por Méndez (1997, p. 5), afirma que "la geografía económica intenta explicar la distribución de los hechos de producción, distribución y consumo". Em trabalho recente, Barnes (2009, p. 315) define a geografia econômica como "a subfield of human geography concerned with describing and explaining the varied places and spaces in which economic activities are carried out and circulate".

Na mesma direção dos excertos anteriores,

The central concerns of economic geography revolve around the ways in which space - in its various manifestations as distance, separation, proximity, location, place etc. dictates the shape and form of economic outcomes. [...] the task of modern economic geography is to provide a reasoned description of the spatial organization of the economy and, in particular, to elucidate the ways in which geography influences the economic performance of capitalism (BENKO; SCOTT, 2004, p. 47). 
A definição anterior vai ao encontro da proposta feita por Coe, Kelly e Yeung (2013), que salientam a imperiosa necessidade de compreender como o espaço cria padrões geográficos, por meio da influência da distância, do território e do lugar, sobre as atividades econômicas. Essa maior interdependência mútua entre espaço e economia também é reforçada por Aoyama, Murphy e Hanson (2011, p. 2011), quando afirmam que os geógrafos econômicos apresentam um interesse comum "in economic processes as fundamentally territorial processes as manifested in the economic fates of communities, cities and regions. The goal [...] is to understand the economic processes of a place, rather than using economic factors as independent or intervening variables".

O primeiro excerto explora a compreensão do sistema econômico no espaço, enquanto as propostas seguintes propõem analisar as inter-relações entre espaço e economia. As definições subsequentes compartilham, de forma inequívoca, a identificação da geografia econômica "con el estudio de las interrelaciones dialécticas existentes entre la actividad económica y el espacio" (MÉNDEZ, 1997, p. 5), a partir de uma dupla perspectiva. Por um lado, "el espacio ejerce una influencia multiforme sobre el funcionamiento económico" e, por outro lado, "una vez implantadas, las actividades económicas ejercen una fuerte influencia sobre la organización del territorio" (MÉNDEZ, 1997, p. 5). Essas mudanças na definição da geografia econômica podem ser apreendidas por meio da análise da evolução dessa subárea dentro da Geografia.

Ainda que a geografia econômica tenha adquirido corpo científico apenas na segunda metade do século XIX, alguns autores (BENKO; SCOTT, 2004; CLAVAL, 2005; BENKO, 2008) têm pontuado a existência de reflexões sobre o papel do espaço nas atividades de produção e consumo, entre os séculos XVII e XIX, no âmbito da emergente econômica política. Esses "elementos espaciais" mostravam a "sensibilidade geográfica" e a potencialidade já existente para a emergência da geografia econômica. Benko (2008, p. 25), porém, afirma que "la réflexion sur l'espace dans la pensée économique a été ponctuelle et relativement marginale". Em outro texto, Benko e Scott (2004, p. 47) destacam que os conteúdos locacionais e espaciais desses trabalhos "almost always functioned as background to more fundamental questions focused on the origins of national wealth and the causes of trade".

A geografia econômica emergiu efetivamente com um corpus teórico durante a segunda metade do século XIX, em um contexto de maior integração internacional e especialização produtiva de cada região (CLAVAL, 2012), dois dos processos que ensejaram um interesse pelos fenômenos da produção e das trocas. Por essa razão, a geografia comercial compreendia todo o domínio da geografia econômica (CAPEL, 1984). Um traço marcante nos trabalhos (W. Götz, K. Ritter, K. Andree, G. Chisholm) era a descrição das diferenciações, as quais, em última instância, eram compreendidas como resultado das influências dos fatores físicos sobre a localização e o desenvolvimento das atividades econômicas. Segundo Méndez (1997, p. 13), esses primeiros trabalhos compartilham "fuerte carga descriptiva y enumerativa, la prioritaria atención concedida a las actividades más relacionadas con los recursos naturales, la influencia del determinismo ambiental y el historicismo en sus explicaciones".

No período entre guerras, as mudanças no contexto internacional, especialmente a perda de importância transitória do imperialismo, contribuíram para a reação ao viés determinista na geografia econômica e a introdução de concepções regionais e paisagísticas e dos métodos das ciências sociais e econômicas. A perspectiva emergente colocou ênfase 
nas "economic interconnections that produced unique and singular regions" (BARNES, 2009 , p. 317). Essas interconexões abrangeriam não somente a dimensão ambiental, mas também a econômica e a institucional, que agiriam reciprocamente na diferenciação regional e na localização da produção (CAPEL, 1984). Barnes (2009, p. 317) destaca que "economic geographical regions, however, were not the same kind of natural phenomena because each region was a collection of exceptional features, describable only in its own terms. No generalization was possible".

Desde os anos 1930, mas com força no pós-segunda Guerra, a crise do liberalismo, a ampliação dos ideais keynesianos, a expansão do modelo fordista de produção, o consumo em massa, o aprofundamento das disparidades espaciais, entre outros, trouxeram à tona a importância da Geografia, contribuindo para a consolidação da análise espacial e da ciência regional (SCOTT, 2003). A geografia econômica das características excepcionais cedeu espaço à aplicação de formas científicas de teorização geral e técnicas estatísticas rigorosas (BENKO, 2008; BARNES, 2009), criando as pontes com a economia espacial são recuperados, nesse momento, os modelos propostos por Christaller, Hoover, Palander, Von Thünen, Weber, entre outros - e uma abertura da Geografia para o planejamento.

Conforme salientam Pereira Junior e Santos (2019, p. 4), "a influência da economia foi tão grande na Geografia que muitos trabalhos foram chamados de economicistas e houve um alerta para a necessidade de uma Geografia Econômica mais geográfica”. Essa nova geografia econômica, ancorada nos modelos elegantes, cujos pressupostos eram problemáticos (equilíbrio espacial, planície isotrópica, racionalidade e informação perfeitas, espaço dotado de fatores dados e fixos etc.), passou a receber duras críticas, a partir dos anos 1960, de um pequeno "groupe de géographes radicaux en révolte contre ce qu'ils considéraient comme l’enfermement méthodologique et la nature foncièrement conservatrice de la science régionale et de l'analyse spatiale" (BENKO, 2008, p. 37).

As críticas aos modelos neoclássicos se deram em um contexto de crise do fordismo nos países centrais, intensificação da internacionalização produtiva, aceleração do desenvolvimento tecnológico, aumento do desemprego e da inflação, proliferação de movimentos sociais por direitos civis, entre outros (SCOTT, 2003). Nesse momento, emergiram, na geografia econômica, os estudos sobre o subdesenvolvimento e o terceiro mundo, as grandes corporações e as tomadas de decisões, a reestruturação produtiva e suas implicações nas paisagens industriais (WALKER, 2012) etc., tendo como forte influência a economia política. Os geógrafos radicais recuperaram as "marxian economic categories (value, surplus, profit, accumulation, etc.), in combination with explicit invocation of the social and property foundations of capitalism and their expression in class struggle" (BENKO; SCOTT, 2004, p. 58).

Pereira Junior e Santos (2019, p. 5) afirmam que "as pesquisas procuraram mostrar que os processos de acumulação e as estruturas sociais relacionadas criavam e recriavam realidades geográficas, mostrando que o espaço não é apenas organizado, ele é produto de relações sociais e de interesses de classes". O espaço construído se tornou uma barreira à rápida realização dos lucros sobre o capital investido na produção (HARVEY, 1982), e a natureza restringiu o imperativo de acumulação interminável (SMITH, 1988). Assim, "both nature and the spatial organization of production are dialectically related to capitalism: they are shaped by, but also shape, its evolution" (SHEPPARD, 2006, p. 14). A concepção de paisagens industriais regulares e estáticas, presentes nos modelos antigos de otimização e difusão, foi substituída pela ideia de que elas são permanentemente transformadas sob o capitalismo. 
Os estudos sobre as mudanças nas paisagens industriais foram renovados a partir dos anos 1980, seja pelos trabalhos sobre o declínio de regiões industriais (cinturões da ferrugem), seja pela emergência de novas espacialidades industriais em áreas sem tradição industrial. Essa nova conjuntura levou à "[...] the emergence or re-emergence of the region as a distinctive and increasingly self-assertive economic unit and pointed to a real need on the part of economic geographers to reconsider the ways in which they had been carrying out their research" (BENKO; SCOTT, 2004, p. 59). A reconsideração teórico-metodológica teve como "conséquences un regain de l’importance accordée aux initiatives locales de développement et une réaffirmation du rôle des acteurs politiques locaux comme agents de changement économique" (BENKO, 2008, p. 39).

A economia política de cunho marxiana foi complementada ou mesmo substituída por outros encaminhamentos. O estudo das localidades na Inglaterra, com Doreen Massey, Andrew Sayer e Richard Meegan, sob forte influência do realismo crítico, manteve as determinações estruturais, mas pôs em relevo as circunstâncias históricas e geográficas, privilegiando uma pesquisa intensiva de estudos de casos. Benko (2008, p. 39) destaca o problema do empirismo e o papel dessa perspectiva nos estudos geográficos: "Ce profond empirisme du mouvement des localités limita son influence intellectuelle et sa durée, mais celui-ci n’en marqua pas moins une étape importante de la transition vers ce qu’on pourrait appeler un nouveau régionalisme en géographie économique".

Segundo Pereira Junior e Santos (2019), o estudo das espacialidades industriais emergentes propiciou a emergência de algumas escolas de pensamento: 1) a Escola Italiana, com a retomada dos estudos dos distritos industriais, marcados por uma produção neoartesanal; 2) a Escola da Califórnia, com suas preocupações em torno da desintegração vertical, custos de transação, mercados de trabalho locais etc.; 3) o Grupo de Pesquisa Europeu sobre Ambientes Inovadores (GREMI), com sua preocupação a respeito da inovação inserida nas relações econômicas e sociais locais; e 4) as ideias sobre Especialização Flexível, com seu paradigma de renovação organizacional de produção. Para Benko (2008, p. 40), essas escolas tinham em comum "le concept d'économies d'agglomération et l'idée de concentration spatiale de l'activité en complexes régionaux spécialisés". Outras características em comum eram o reescalonamento do Estado e a valorização das especificidades locais nas dinâmicas econômicas (SHEPPARD, 2006), sob influência da escola da regulação e das formas regionais da acumulação flexível.

As frustrações com as limitações teóricas anteriormente escrutinadas, combinadas com o debate sobre os limites do estruturalismo para explicar as mudanças do capitalismo, marcaram a virada cultural na geografia econômica a partir dos anos 1990. Os mercados foram despidos das abordagens econômicas abstratas e inseridos em contextos sociais e culturais, e os próprios processos econômicos foram moldados por entendimentos discursivos (SHEPPARD, 2006). Os principais efeitos dessa reorientação foram: "rethinking the discipline's object of inquiry, theory, and methods, and using case studies of particular substantive topics to work through a cultural approach" (BARNES, 2009, p. 319). [...] "les partisans du tournant culturel tendent à construire leurs approches de l'analyse du paysage économique sur des concepts comme le corporel, la performativité, l'identité, le genre, etc" (BENKO, 2008, p. 42-3).

O desenvolvimento da geografia econômica, aqui parcialmente analisado, permite verificar sua lógica interna particular dentro da própria ciência geográfica, com constantes rupturas e recomposições decorrentes tanto das condições internas da Geografia (modelos 
e métodos) quanto das influências externas (mudanças nas ciências econômicas e nas condições de produção) (BENKO, 2008). As tendências verificadas nessa subárea geralmente não partem de contribuições anteriores, colaborando para um palimpsesto de velhas e novas ideias (BENKO; SCOTT, 2004) e para a interdição na criação de espaços de comunicação que permitam explorar as diferenças (SHEPPARD, 2006). Na próxima seção, vamos interpretar as diferentes concepções de firma segundo as abordagens prevalentes na geografia econômica e delinear teorias da firma desenvolvidas recentemente em outros campos disciplinares.

\section{Perspectivas da firma na Geografia Econômica}

Considerando os elementos já reunidos anteriormente sobre emergência e consolidação da geografia econômica, orientações teórico-metodológicas e temáticas, entre outros, torna-se importante, neste momento, entender como se dá a incorporação e a discussão da firma nos estudos geográficos, pontuando suas potencialidades e suas fragilidades, bem como identificar e delinear as teorias da firma desenvolvidas mais recentemente em outros campos disciplinares (especialmente em economia, sociologia e ciência política) e a possibilidade de sua incorporação e utilização nos estudos de geografia econômica.

Maskell (2001), Taylor e Asheim (2001) e Santos (2020) trazem elementos para pensar na firma segundo os encaminhamentos teórico-metodológicos prevalentes na geografia econômica. A maior preocupação com a firma se deu com a emergência dos estudos locacionais e do planejamento, especialmente a partir dos anos 1920, sob influência da economia espacial e da ecologia humana (CORRÊA, 1986). Nesse momento, a firma era, antes de tudo, [...] "a black box within which responses to external pressures are completely rational and, in doing so, completely defines it by its production function" (TAYLOR; ASHEIM, 2001, p. 316). A firma foi reduzida a uma função de produção, atomizada pela competição e informação perfeitas, e havia uma ausência completa das relações sociais de produção, decisões de produção e investimentos, formas organizacionais etc. (SANTOS, 2019).

Sob a influência da economia política marxista, o individualismo metodológico prevalente na economia espacial se tornou insuficiente para lidar com as grandes forças estruturais (SCOTT, 2003) e as relações sociais de produção. Nesse contexto, a geografia econômica "largely bypassed the firm as a theoretical entity in its own right" (MASKELL, 2001, p. 331), relegando-a "position of an irrelevant analytical category subsumed within the logic of capital and capitalist class relations" (TAYLOR; ASHEIM, 2001, p. 316). Sem dúvida, Walker (1989) foi um dos grandes detratores dos estudos de geografia corporativa com centralidade na firma, apontando que "the corporation is an effective instrument of capitalist development but not the essential cause of it; that lies deeper within the economic structure" (WALKER, 1989, p. 50).

Maskell (2001, p. 331) entende que a falta de tratamento teórico da firma está relacionada às metodologias e preocupações específicas da geografia econômica, preocupada com as "forces that are responsible for the actual distribution of economic activity over space and for changes in this distribution as being of a social or economic nature or both". Nos trabalhos práticos, porém, "pivotal theoretical concepts used in the analyses are typically found on the macrolevel, where agency is usually absent" (MASKELL, 2001, p. 331). 
Nesse sentido, conforme salientado alhures (SANTOS, 2020), as forças econômicas e sociais responsáveis pelas mudanças na distribuição espacial das atividades econômicas têm sido os desequilíbrios (neoclássicos) ou os processos de desenvolvimento capitalista desigual e as tendências inerentes de aglomeração e concentração espacial (marxistas).

Com a introdução de novos elementos para a análise dos fenômenos econômicos a partir dos anos 1990, especialmente dos estudos das novas espacialidades industriais e renovação dos estudos regionais, da virada cultural e da retomada da antropologia econômica na Geografia, a teoria da firma foi ampliada, indo além das causalidades econômicas, na medida em que incorporou regras, rotinas, enraizamento social, recursos, aprendizados etc. Apesar da maior contextualização socioeconômica das abordagens, Maskell (2001) aponta que a firma não ganhou status de entidade teórica própria. Essas abordagens deram pouca importância para as influências dinâmicas "of place, space, and spatiality in shaping's firms operations. Moreover, they never quite come to grips with issues of multilocationality; treat time ambiguously, as an implicit evolutionary sequence divorced from historical specificity" (TAYLOR; ASHEIM, 2001, p. 317).

O levantamento e a revisão bibliográficos na literatura mais recente sobre a firma, sendo a maior parte dos trabalhos realizada na economia, na administração, na sociologia, na geografia, entre outros campos disciplinares, revelam a existência de diversas abordagens que, embora possam ser complementares quanto aos objetivos (o que é, quais relações com o entorno e como se organiza), não podem ser enquadradas em um corpus teórico único e coerente. Todas as perspectivas identificadas são diferentes no tocante ao método de interpretação, à natureza da firma (produção e transação) e ao objeto de análise (indústria e contextos institucionais e históricos).

Alguns esforços têm sido feitos visando agrupar as teorias da firma em grandes abordagens teórico-metodológicas (TIGRE, 1998; MASKELL, 2001; TAYLOR; ASHEIM, 2001; TAYLOR, 2006). A partir de levantamento bibliográfico que realizamos na literatura especializada (SANTOS, 2020), identificamos nove abordagens sobre a firma que, embora distintas, são complementares quanto às preocupações centrais em relação à natureza e aos processos dentro e no seu entorno. Em seguida, vamos apresentar essas teorias e suas principais proposições, a fim de reunir elementos necessários à reflexão sobre quais teorias da firma poderiam ser incorporadas nos estudos de geografia econômica.

\section{Custos de transação}

A firma é vista como uma entidade contratual em que a forma e as suas operações são moldadas pelos custos de usar os mecanismos de preços no mercado (COASE, 1937). Para descobrir os preços, negociar, concluir e garantir o cumprimento dos contratos, a firma incorre em custos. Quando esses custos forem maiores ao serem realizados pelo mercado, a firma tenderá a internalizá-los dentro de suas estruturas, ao passo que, em situação inversa, optará pelos mecanismos de mercado. Sob essa perspectiva, firma e mercado são vistos como formas alternativas de coordenação da produção; quer dizer, seriam completamente opostos.

\section{Gerencial e comportamental}

Sob forte influência da perspectiva comportamental, a firma não é um meio de maximização dos lucros, mas uma organização complexa, marcada por racionalidade limitada e conhecimento imperfeito. A ênfase na administração da firma, por meio das 
análises da definição dos seus objetivos e do processo de tomada de decisões, mostra uma coalizão de agentes (gerentes, proprietários, acionistas, fornecedores, varejistas etc.) com interesses conflitantes, decisões dos gerentes para além da maximização dos lucros e decisões subótimas (FEIJÓ; VALENTE, 2004).

\section{Direitos de propriedade}

Essa perspectiva de direitos de propriedade emerge a partir das críticas feitas pela abordagem gerencial e comportamental aos pressupostos neoclássicos. Admitindo a racionalidade limitada e o oportunismo dos agentes, propõe pensar que toda troca entre agentes seria uma troca de direitos de propriedade sobre os objetos. As diferentes organizações econômicas seriam um reflexo da configuração dos direitos de propriedade. Assim, os diferentes tipos e sistemas de propriedade atuariam sobre o comportamento dos agentes individuais e sobre a eficiência do sistema econômico (SANTOS, 2020).

\section{Custos de agência}

Trata-se de uma abordagem complementar à de direitos de propriedade, que também admite a informação imperfeita, as assimetrias entre os agentes e a falta de tomada de decisões ótimas. A firma é vista como um nexo de contratos e relações de agência (contratos formais e informais de indivíduos que delegam uma função a outros indivíduos). Assim, mercado e firma não são antagônicos, e a própria firma é diluída em um individualismo metodológico, imbricada em um múltiplo conjunto de relações entre indivíduos (CORIAT; WEINSTEIN, 2011).

\section{Institucionalista}

Recusando os contratos e a maximização, os institucionalistas propõem pensar na empresa, grande ou pequena, como uma "institucionalização duradoura dos hábitos, tradições, regras e rotinas de fazer negócios em um lugar" (TAYLOR, 1999, p. 4). No lugar de maximizar os lucros ou minimizar os custos, a firma seria uma estrutura institucional que permitiria subsumir a própria lógica do cálculo de custos. A institucionalização de regras e rotinas dentro das estruturas organizacionais possibilitaria a sobrevivência das firmas em um mercado marcado por volatilidade.

\section{Recursos e competências}

Na mesma direção da vertente institucionalista, inserem-se novos elementos à análise das firmas, propondo compreendê-las como uma coleção de recursos produtivos. A existência e o crescimento das firmas dependeriam de seus fatores internos e de suas competências (conhecimentos) construídas a partir do aprendizado e da repetição. Essas competências (rotinas ou aprendizagens) seriam heterogêneas, na medida em que cada firma combina os recursos com ativos difíceis de imitar, e se modificariam "ao longo do tempo, como resultado de esforços deliberados para a superação de problemas e eventos aleatórios" (NELSON; WINTER, 2005, p. 19). Assim, são os aprendizados ou rotinas (habilidades) tácitos que permitem que as firmas sobrevivam ao entorno em constante mudança.

\section{Redes e enraizamento}

Desloca-se a análise do mercado e da hierarquia para as relações laterais e horizontais entre firmas, com a inserção das trocas nos contextos sociais e contingências sociais, 
culturais, cognitivas e institucionais. Tanto o empreendedorismo como a inovação e o crescimento são analisados na sua imersão dentro de um contexto social. As firmas são inseridas em redes de reciprocidade, interdependência e relações de poder desiguais (TAYLOR; ASHEIM, 2001). Dessa maneira, a firma é uma organização coletiva de aprendizado baseada na ampla participação de agentes e de organizações, em que as transações são mais sociais do que econômicas.

\section{Discursiva}

A firma é vista "como uma constelação de relações em rede governadas por atores sociais por meio de práticas materiais e discursivas" (YEUNG, 2005, p. 310). Os atores sociais estão enraizados em relações sociais diversas (interpessoais, de parentesco, ligações sociais etc.), que se constituem nos limites da própria firma, tornando-a mais híbrida. As práticas materiais e discursivas dos atores, no âmbito da firma, estão imersas em geometrias de poder específicas e são diferenciadas segundo as escalas espacial e organizacional. Essa visão relacional de firma contribui para pensar no mercado e na firma como construções sociais, de um lado, e permite entender, de outro lado, o desenvolvimento e a dinâmica da firma no bojo de relações sociais e das lutas discursivas entre atores sociais.

\section{Coalizões temporárias}

Sob essa perspectiva, os aspectos de racionalidade e desempenho, além daqueles de propriedade, são deixados de lado, visando compreender os processos da empresa, os quais são constituídos por coalizões temporárias de pessoas que se mobilizam em momento e local específicos, com a finalidade de utilizar ativos (competências) para gerar riqueza pessoal. As firmas são criadas, reformuladas ou dissolvidas a partir da coalizão de grupos de pessoas (empreendedores ou tomadores de decisão) que usam e redefinem ativos em busca da riqueza pessoal (TAYLOR, 2004). Com essa abordagem, abre-se a possibilidade de entender o papel dos indivíduos na formação das firmas, suas conexões e temporalidade dos negócios em espaços e tempos específicos.

As nove abordagens/propostas teóricas sintetizadas anteriormente são marcadas por um individualismo metodológico (com ênfase nos processos dentro e no entorno das firmas) ou por uma preocupação em inserir as firmas em uma estrutura mais ampla do sistema econômico (SANTOS, 2020). O grande desafio é pensar na incorporação dessas abordagens considerando as especificidades e particularidades da geografia econômica. Na seção seguinte, alguns ensaios são feitos nessa direção.

\section{Quais teorias da firma para a Geografia Econômica?}

A existência de muitas teorias da firma - são concorrentes, em sua maior parte, do que complementares - dificulta qualquer mudança de uma perspectiva por outra sem que haja uma alteração na estrutura explicativa do argumento (MASKELL, 2001). Cada uma delas, auxiliadas por um método, pressupõe uma "visão de mundo". É por esse motivo e também pela preocupação de utilizar criticamente teorias de outros campos disciplinares que Maskell (2001) alerta para a importância de se pensar em critérios de incorporação e utilização das teorias da firma, respeitando as especificidades dos estudos na geografia econômica. 
Maskell (2001, p. 338) sugere que levemos em consideração dois aspectos. O primeiro deles é que "an adequate theory of the firm would necessarily be in compliance with the rationality assumptions on which other theories in economic geography are based". O segundo é que uma "theory of the firm that is particularly suited to economic geography may thus be selected on the basis of its ability to lend itself to theoretical and empirical work on different levels of spatial aggregation" (grifo do autor). Esses dois aspectos indicam que a escolha de qualquer teoria da firma tem que ser coerente com o corpus teórico prevalente na geografia econômica, de um lado, e permitir uma análise, de outro lado, não apenas no âmbito da firma, mas também das dinâmicas econômicas nas múltiplas escalas.

Seguindo a proposição de Maskell (2001), o primeiro aspecto pressupõe aceitar, atualmente, aquelas teorias da firma que se baseiam na suposição de racionalidade incompleta dos agentes econômicos, em detrimento das proposições de racionalidade completa, sejam elas neoclássicas ou estruturalistas. Já o segundo aspecto, preocupado com a utilização de uma teoria da firma para explicar os contextos espaciais em que as firmas estão inseridas, sinaliza para a incorporação da teoria evolucionária baseada nas competências da firma, no lugar da teoria dos direitos de propriedade ou dos custos de transação. Esses dois aspectos mostram a preocupação do autor ao considerar os agentes econômicos como centrais para entender as dinâmicas territoriais nas várias escalas (OINAS, 2006).

Amin e Thrift (2000, p. 7) reconhecem que, sob influência da economia institucional e evolucionária, a interpretação das firmas foi alargada para além daquela visão de agente racional processador eficiente de informações e de organização eficiente dos custos de transação no mercado, pois insere variáveis como hábitos, rotinas, convenções, dependência de trajetória, variedade no ambiente de seleção na leitura dos ritmos e direções de aprendizado e adaptação nas firmas. Nessa direção, os geógrafos, por meio dos estudos sobre os efeitos da proximidade, distância, contexto local e fontes de inovação, aportaram contribuições relevantes, permitindo interpretar a inovação, o espaço e as firmas como indissociáveis.

Os autores referenciados, embora apresentem os avanços proporcionados pelas perspectivas baseadas nas competências, levantam alguns óbices à sua utilização. Para Amin e Thrift (2000, p. 7), "competence-based perspective does not get us close enough to the micro-practices in firms that nurture, sustain, and even compromise everyday learning". As grandes empresas evitam "the peril of failure at every turn through the daily interplay between procedural and recursive knowledge among individuals and groups within firms [...] this daily practice is also the source of learning, in forms of knowledge generated through practice, social interaction, and action" (AMIN; THRIFT, 2000, p. 7). Para entender esse aprendizado e seus efeitos econômicos, os autores sugerem o estudo antropológico das comunidades de práticas nas empresas.

Taylor (2006) também é crítico com relação à abordagem de firma baseada em recursos e competências, pois, assim como as outras, tem como pano de fundo as questões sobre por que existem as firmas, o que determina os seus limites em relação ao mercado e a sua organização interna. A teoria baseada nos recursos e competências seria uma perspectiva fragmentada com lacunas, compreendendo volumosos microprocessos empíricos que "[...] offer little empirical insight into historical sequences of changing organizational forms in time" (TAYLOR, 2006, p. 21). Em outras palavras, seria uma abordagem do tempo, mas não no tempo, na medida em que os microprocessos são removidos das especificidades do tempo histórico. 
Markusen (2005), na mesma direção, faz uma dura crítica ao que seria a ausência dos "atores" na economia regional e na geografia econômica, seja por conta dos papéis causais a fenômenos subteorizados, como as relações de aprendizagem, amplamente discutidas pelo viés evolucionista, seja pela voz passiva usada para retratar dinâmicas sem atores nos trabalhos sob o viés de economia política (fazendo alusão a Richard Walker e seu célebre texto Réquiem para a geografia das corporações). A autora sugere uma ênfase renovada nos atores e no processo decisório da corporação, "no contexto das condições em que ocorre, indústria por indústria, tipo de mercado por tipo de mercado, numa geografia econômica crítica" (MARKUSEN, 2005, p. 66).

O desafio que está colocado é ir além dos estudos fragmentados e compartimentados, com ênfase nas determinações estruturais do sistema econômico, nas particularidades de uma indústria específica ou nos estudos de caso em territórios específicos. Em outras palavras, é premente construir abordagens com mediações - dimensão meso - que permitam conectar as dimensões macro e micro (POSSAS, 1987; SANTOS, 2012). Dicken (2013, p. 37) fez um apelo para uma maior fertilização cruzada "between researchers in different traditions: for a geography of enterprise to be more firmly embedded within the broader structure of the production system as whole and for students of the production system to pay more explicit attention to the enterprise".

Taylor e Thrift (1982a, 1982b, 1983) e Taylor $(1984,1985)$, em diferentes trabalhos, procuraram viabilizar a integração ou a mediação entre as abordagens abstratas, empiristas e fragmentadas existentes sobre a firma. O principal propósito dos autores foi inserir as organizações econômicas como agentes centrais das mudanças econômicas e espaciais, elegendo a firma como unidade básica da economia, o ponto de encontro das forças macro e micro (SANTOS, 2021). A segmentação econômica entre pequenas e grandes empresas foi analisada tendo as redes de poder como elemento central, posto que ela é o resultado do "access of organizations to resources, and thus power relationships", que "[...] are highly uneven and strongly asymmetric" (TAYLOR; THRIFT, 1982b, p. 1604, grifo nosso).

A segmentação econômica das empresas deveria ser pensada para além das dicotomias, pois seriam segmentos inter-relacionados sob a mediação de relações de poder. Assim, "the dualistic economy does not consist of two closed systems, but rather of a set of interrelated segments" (TAYLOR; THRIFT, 1982b, p. 1609). O próprio padrão de segmentação econômica não seria ad aeternum, porque as crises de acumulação ensejariam a emergência de novos segmentos e novas relações de dominação e subordinação. Essa dinâmica se daria em função da emergência de novos "dominant segments which are both the cause and the result of crises of accumulation. As each of these new dominant segments emerges so new relations or domination and/or subordination have become established while the old relations have to be renegotiated" (TAYLOR; THRIFT, 1983, p. 450, grifo nosso).

Yeung (1994) aponta alguns problemas da teoria das redes de poder, como o foco no aspecto econômico em detrimento das tomadas de decisões e das relações de barganha, a classificação a priori das firmas, as inter-relações entre firmas dentro dos segmentos, a ausência de sua inserção em redes de relações de poder e, por último, a desconsideração dos limites das firmas. Santos (2021) acrescenta ainda a falta do papel do Estado, a ausência dos conflitos capital-trabalho e a concepção estática da inovação. Nos anos 1980 e 1990, os trabalhos sobre distritos industriais e meios inovadores reascenderam a discussão acerca das redes interfirmas, tendo como foco a organização espacial das redes 
(CAMAGNI, 1993). Os avanços alcançados quanto às relações entre firmas em rede e dimensão espacial foram acompanhados, porém, pela ausência de preocupação com os enraizamentos institucionais e socioculturais, desconsideração das relações intrafirmas, excessos de resultados empíricos com pouca preocupação com a construção e formação causal dos fenômenos (YEUNG, 1994).

Para Yeung (1994), a análise das redes sob a ótica do enraizamento da ação econômica em redes de relações sociais permite superar as generalizações do mainstream existente no estudo da organização industrial (escola da regulação e acumulação flexível). O autor defende a reconstrução da geografia das empresas e dos sistemas produtivos "on the basis of a 'bottom-up' and network-relation approach which seek to construct the social formation of network relations at the intra, inter and extrafirm levels and to examine the role of these network relations in understanding the landscape of the capitalist global economy" (YEUNG, 1994, p. 483). Nessa mesma direção, Dicken e Malmberg (2001) propõem uma perspectiva relacional que considere os nexos de três dimensões - firmas, sistemas industriais e territórios - e sua inserção em uma dimensão macro de sistema de governança.

A partir da ideia dos sistemas, cada atividade econômica em particular é vista como inserida/imersa em uma rede de relações funcionais (transações, competição, colaboração etc.) e territoriais (proximidade, ambientes institucional e regulatório etc.) com outras atividades, levando à configuração de sistemas produtivos complexos. As transformações na paisagem industrial não se restringiriam às operações de firmas individuais, posto que o ponto de partida seria o sistema industrial. Tal perspectiva também possibilitaria superar as dicotomias (pequenas e grandes empresas, manufatureiro e serviços, empresas nacionais e empresas estrangeiras etc.) existentes nas análises geográficas.

As firmas seriam "both primary agents of and, at the same time, encapsulated within the kinds of industrial system" (DICKEN; MALMBERG, 2001, p. 350). Nas palavras dos autores, "although we cannot understand how firms behave without a clear understanding of their structural position, neither can we fully understand the workings of industrial systems without an understanding of firms" (DICKEN; MALMBERG, 2001, p. 350). As visões de firmas com limites precisos, autônomas, racionais e organizadas hierarquicamente são desconstruídas com novos elementos - reconfiguração constante dos limites organizacionais, conflitos e interesses nas tomadas de decisões e redes de poder e contestação. Com base nesses elementos, defende-se que as "firms are essentially networks within networks" (DICKEN; MALMBERG, 2001, p. 352, grifo dos autores).

Os territórios seriam "as 'containers' of sets of physical, social, cultural, political, and economic attributes", dispostos "along a continuum of scales, each individual scale being contingent and socially constructed” (DICKEN; MALMBERG, 2001, p. 354). Os estudos sobre os impactos territoriais das firmas deveriam considerar a diversidade de formas organizacionais existentes e seus nexos com a diferenciação territorial na qual se inserem. As firmas seriam espaciais, em resposta às distâncias e variações espaciais na disponibilidade de recursos, e também territoriais, por operarem sob um mosaico de entidades territoriais ao longo de um continuum de escalas sobrepostas. Alguns aspectos das firmas seriam derivados e também influenciados por lugares e territórios específicos de atuação. A própria dinâmica competitiva e inovativa nas indústrias de atuação das firmas seria influenciada por circunstâncias territoriais (relações face a face, conhecimento tácito, rotinas etc.). 


\section{Considerações finais}

A revisão bibliográfica mostra que, durante os diferentes momentos pelos quais passou a geografia econômica, a firma não recebeu um adequado tratamento teórico sobre o que é, como é constituída, qual é a sua dinâmica e seus limites, entre outros. A revisão de literatura mostra ainda a falta de um corpus teórico único e coerente da firma nos diferentes campos disciplinares em que ela tem sido abordada, e, no caso da geografia econômica, isso tem a ver com as dificuldades de se explicar as complexidades das mudanças econômicas e espaciais contemporâneas e os encaminhamentos teórico-metodológicos prevalentes.

À luz dos principais fundamentos ontológicos e epistemológicos presentes na geografia econômica, a firma aparece de forma estilizada e cristalizada, ora como sinônimo de eficiência (neoclássicos e estruturalistas), ora como uma construção social e coletiva (institucionalistas e evolucionistas). Então, a partir do levantamento e sistematização bibliográficos, identificamos nove abordagens sobre a firma (custos de transação; gerencial e comportamental; direitos de propriedade; custos de agência; institucionalismo; recursos e competências; redes e enraizamento; discursiva; coalizões temporárias). Taylor e Asheim (2001) e Taylor (2006) enquadram essas nove teorias em dois grandes paradigmas: racionalistas (contratos completos e incompletos) e socioeconômicos.

Nas perspectivas racionalistas, os trabalhos abordam a raison dêtre da firma como busca pela maximização do lucro e eficiência. Muitas vezes, a firma aparece como: 1) local de produção que transforma um conjunto de produtos em outros produtos sob a regulação do mercado e das relações de troca; 2) entidade contratual moldada pelos custos de realização de trocas no mercado; e 3) local de tomada de decisões que envolvem conflitos, incerteza, aprendizado e adaptação. Sob as perspectivas socioeconômicas, tanto a economia como a firma são uma construção social, sendo o objetivo central desvelar os processos que operam dentro da firma - regras e rotinas construídas, redes enraizadas, competências, discursos etc.

As diferentes teorias - racionalistas e socioeconômicas - exibem certa complementaridade quanto à natureza e processos dentro e no entorno da firma. Elas também compartilham uma perspectiva de firma como fenótipo ou algo dado dentro de um contexto maior, no qual se insere passivamente. Em todas elas, a firma é inerte, não interage e tampouco define as relações, constituindo-se apenas em um "meio" a partir do qual os processos econômicos e sociais se encontram, interagem e se realizam. Em outras palavras, a firma é uma forma de organização que se insere apenas como mais um elemento no sistema econômico, e como a lógica de causalidade é perpassada, sempre, por relações econômicas, então a firma não passa de uma cristalização de esforços comerciais.

As perspectivas mais recentes - discursivas e coalizões temporárias - destacam as relações sociais e os conflitos na formação e desenvolvimento das firmas, realçam novos aspectos e sedimentam uma leitura desconectada dos processos mais gerais. Sendo a firma a unidade básica da economia ou o ponto de produção em que se encontram e se realizam forças micro e macro (TAYLOR, 1984), precisamos inserir as categorias e conceitos geográficos na mediação dessas duas forças. Nessa direção, Dicken e Malmberg (2001) defendem a potência das abordagens "relacionais" para entender as interconexões entre territórios e atividades econômicas, enfatizando os nexos das três dimensões - firmas, sistemas industriais e territórios. Markusen (2005) clama por uma economia política que, em vez de abandonar os "processos", incorpore as nuanças institucionais e as abordagens centradas no ator e no processo decisório. 


\section{Referências}

AMIN, A.; THRIFT, N. What kind of economic theory for what kind of economic geography. Antipode, Oxford, v. 32, n. 1, p. 4-9, 2000.

AOYAMA, Y.; MURPHY, J. T.; HANSON, S. Key concepts in economic geography. Londres: Sage Publications, 2011.

BARNES, T. J. Economic geography. In: KITCHIN, R.; THRIFT, N. (Ed.). International Encyclopedia of Human Geography. Amsterdam: Elsevier, 2009. p. 315-327.

BENKO, G. La géographie économique: un siècle d'histoire. Annales de Géographie, Paris, v. 664, n. 6, p. 23-49, 2008.

BENKO, G.; SCOTT, A. Economic geography: tradition and turbulence. In: BENKO, G.; STROHMAYER, U. (Ed.). Human geography: a history for the 21st century. Oxford: Oxford University Press, 2004. p. 47-63.

CAMAGNI, R. From city hierarchy to city network: reflections about an emerging paradigm. In: LAKSHMANAN, T. R.; NIJKAMP, P. (Ed.). Structure and change in the space economy. Berlin: Springer/Verlag, 1993. p. 66-87.

CAPEL, H. Geografía y economía. In: CAPEL, H. Geografía humana y ciencias sociales: una perspectiva histórica. Barcelona: Montesinos, 1984. p. 83-122.

CLAVAL, P. Geografía económica. Barcelona: Oikos-Tau, 1980.

CLAVAL, P. Geografia econômica e economia. GeoTextos, Salvador, v. 1, n. 1, p. 11-27, 2005.

CLAVAL, P. A diversidade das geografias econômicas. GEOgraphia, Niterói, v. 14, n. 2, p. 7-20, 2012.

COASE, R. H. The nature of the firm. Economica, London, v. 4, n. 16, p. 386-405, 1937.

COE, N. M.; KELLY, P. F.; YEUNG, H. W. C. Economic geography: a contemporary introduction. Wiley, 2013.

CORIAT, B.; WEINSTEIN, O. Nuevas teorías de la empresa: una revisión crítica. Carapachay: Lenguaje Claro, 2011.

CORRÊA, R. L. O enfoque locacional na Geografia. Terra Livre, São Paulo, n. 1, p. 62-66, 1986.

DICKEN, P. The geography of enterprise: elements of a research agenda. In: SMIDT, M.; WEVER, E. (Ed.). The corporate firm in a changing world economy: case studies in the geography of enterprise. Londres: Routledge, 2013. p. 234-244.

DICKEN, P.; MALMBERG, A. Firms in territories: a relational perspective. Economic Geography, Worcester, v. 77, n. 4, p. 345-363, 2001.

FEIJÓ, C. A.; VALENTE, E. A firma na teoria econômica e como unidade de investigação estatística: evolução nas conceituações. Revista de Economia Contemporânea, Rio de Janeiro, v. 2, n. 8, p. 351-376, 2004.

HARVEY, D. The limits to capital. Chicago: University of Chicago Press, 1982.

LLOYD, P. E.; DICKEN, P. Location in space: a theoretical approach to economic geography. New York: Harper \& Row, 1972.

MARKUSEN, A. Mudança econômica regional segundo o enfoque centrado no ator. In: DINIZ, C. C.; LEMOS, M. B. (Ed.). Economia e território. Belo Horizonte: Editora UFMG, 2005. p. 57-75.

MASKELL, P. The firm in economic geography. Economic Geography, Worcester, v. 77, n. 4, p. 329-344, 2001.

MÉNDEZ, R. Geografía económica: la lógica espacial del capitalismo global. Barcelona: Editora Ariel, 1997.

NELSON, R. R.; WINTER, S. G. Uma teoria evolucionária da mudança econômica. Campinas: Editora da Unicamp, 2005.

OINAS, P. Theorizing the firm in economic geography. In: TAYLOR, M.; OINAS, P. (Ed.). Understand the firm: spatial and organizations dimensions. Oxford: Oxford University Press, 2006. p. 237-254.

PEREIRA JUNIOR, E.; SANTOS, L. B. Produção bibliográfica em geografia da indústria e dos sistemas produtivos. Mercator, Fortaleza, v. 18, e18014, 2019.

POSSAS, M. L. Dinâmica da economia capitalista: uma abordagem teórica. São Paulo: Brasiliense, 1987.

SANTOS, L. B. Estado, industrialização e os espaços de acumulação das Multilatinas. 2012. $541 \mathrm{f}$. Tese (Doutorado em Geografia)-Faculdade de Ciências e Tecnologia, Universidade Estadual Paulista, Presidente Prudente, 2012.

SANTOS, L. B. Teorias da firma na Geografia Econômica. In: SPOSITO, E. S.; CLAUDINO, G. S. Teorias na Geografia: avaliação crítica do pensamento geográfico. Rio de Janeiro: Consequencia, 2020. p. 323-350. 
SANTOS, L. B. Trajetórias de consolidação, movimentos setoriais e internacionalização do grande capital brasileiro. In: OLIVEIRA, F. G. et al. (Ed.). Espaço e economia: geografia econômica e a economia política. 1. ed. Rio de Janeiro: Consequencia, 2019. p. 511-552. v. 1.

SANTOS, L. B. Economic segmentation and networks of power: the topicality of Taylor and Thrift theory. Ateliê Geográfico, Goiânia, v. 15, n. 1, 2021. No prelo.

SCOTT, A. Economic geography: the great half-century. In: CLARK, G. L.; FEDMAN, M. P.; GERTLER, M. S. (Ed.). The Oxford handbook of economic geography. Oxford: Oxford University Press, 2003. p. 18-44.

SHEPPARD, E. The economic geography project. In: BAGCHI-SEN, S.; SMITH, H. L. (Ed.). Economic geography: past, present and future. Londres: Routledge, 2006. p. 11-23.

SMITH, N. Desenvolvimento desigual. Rio de Janeiro: Bertrand, 1988.

SPOSITO, E. S. A propósito dos paradigmas de orientações teórico-metodológicas na Geografia contemporânea. Terra Livre, São Paulo, n. 16, p. 99-112, 2001.

TAYLOR, M. Industrial geography. Progress in Human Geography, London, v. 8, n. 2, p. 263-274, 1984.

TAYLOR, M. Industrial geography. Progress in Human Geography, London, v. 9, n. 3, p. 432-442, 1985.

TAYLOR, M. The small firm as a temporary coalition. Entrepreneurship and Regional Development, London, v. 11, n. 1, p. 1-19, 1999.

TAYLOR, M. The firm as a connected, temporary coalition. Marburg: Philipps University, 2004. (SPACES Working Paper).

TAYLOR, M. Fragments and gaps: exploring the theory of firm. In: TAYLOR, M.; OINAS, P. (Ed.). Understand the Firm: spatial and organizations dimensions. Oxford: Oxford University Press, 2006, p. 3-31.

TAYLOR, M.; ASHEIM, B. The concept of the firm in economic geography. Economic Geography, Worcester, v. 77, n. 4, p. 315-328, 2001.

TAYLOR, M.; THRIFT, N. Industrial linkage and the segmented economy 2: an empirical reinterpretation. Environment \& Planning A, Thousand Okas, v. 14, n. 12, p. 1615-1632, 1982a.

TAYLOR, M..; THRIFT, N. Industrial linkage and the segmented economy: 1. Some theoretical proposals. Environment \& Planning A, Thousand Okas, v. 14, n. 12, p. 1601-1613, 1982 b.

TAYLOR, M.; THRIFT, N. Business organization, segmentation and location. Regional Studies, London, v. 17, n. 6 , p. $445-465,1983$.

TIGRE, P. B. Inovação e teorias da firma em três paradigmas. Revista de Economia Contemporânea, Rio de Janeiro, n. 3, p. 67-111, 1998.

WALKER, R. A requiem for corporate geography: new directions in industrial organization, the production of place and the uneven development. Geografiska Annaler, Stockholm, v. 71, p. 43-68, 1989.

WALKER, R. Geography in economy: reflections on a field. In: BARNES, T. J.; PECK, J.; SHEPPARD, E. (Ed.). The Wiley-Blackwell companion to Economic Geography. Oxford: Blackwell Publishing, 2012. p. 47-60.

YEUNG, H. W. Critical reviews of geographical perspectives on business organizations and the organization of production: towards a network approach. Progress in Human Geography, London, v. 18, n. 4, p. 460-490, 1994.

YEUNG, H. W.-C. The firm as social networks: an organizational perspective. Growth and Change, Lexington, v. 36, n. 3, p. 307-328, 2005.

SOBRE O AUTOR

Leandro Bruno Santos. Professor do Departamento de Geografia de Campos (GRC) e do Programa de Pós-Graduação em Geografia (PPG) da Universidade Federal Fluminense. 
SEÇÃO IV

\section{Desafios \\ da geografia ambiental}




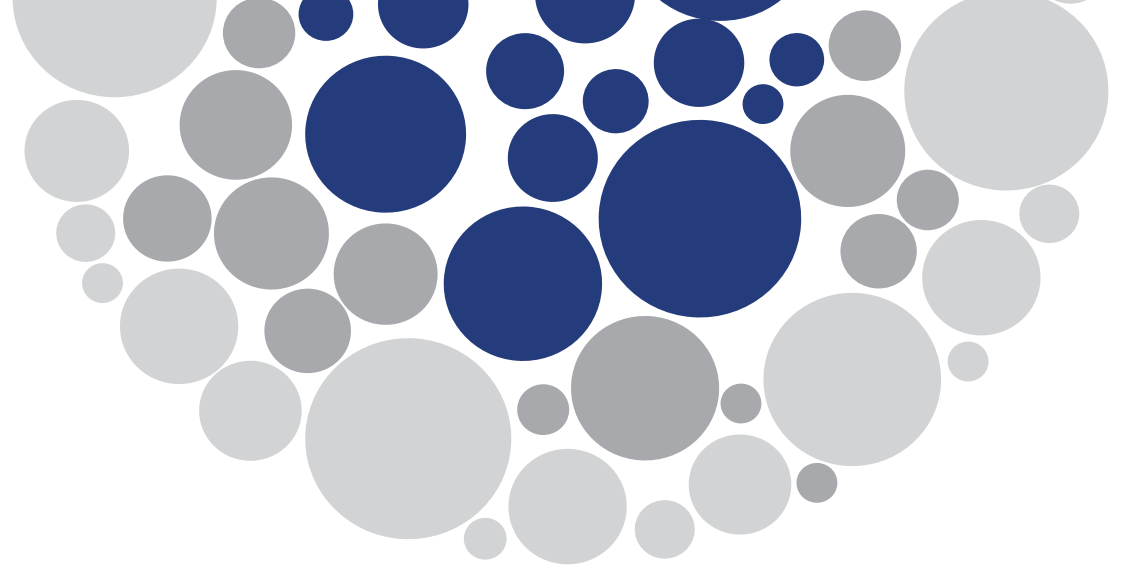

\title{
A Conferência de Estocolmo e as posturas políticas diante da questão ambiental
}

\author{
Arthur Soffiatia \\ a Universidade Federal Fluminense, RJ, Brasil. E-mail: as-netto@uol.com.br
}

Se a Conferência de Estocolmo, realizada em 1972 pela Organização das Nações Unidas (ONU), não conseguiu um consenso dos Estados-membros quanto ao enfrentamento da crise ambiental global que já vinha sendo percebida e que motivou a histórica reunião, ao menos pode-se tomá-la como marco para o reposicionamento político de liberais, socialistas e anarquistas ou mesmo para a reafirmação de suas posturas políticas tradicionais. Para começar a discussão, não podemos esperar tipos ideais ao estilo de Max Weber. Aliás, esse sociólogo só construiu tipos ideais para, a partir deles, buscar apreender a complexidade de cada postura política.

Para compreender os posicionamentos político-filosóficos dos atores sociais que emergiram da Conferência de Estocolmo, cumpre retornar ao século XVIII, ao Iluminismo, à Revolução Francesa. Simplificando, podemos dizer que, na transição do século XVIII para o XIX, três tendências se afirmaram: o liberalismo, o socialismo e o anarquismo. A crise ambiental global está estava em marcha desde o século XV com a expansão europeia. No fim do século XVIII, ela se aprofundou com a Revolução Industrial, aliás tomada superficialmente como marco para a crise. Adam Smith e François Quesnay afirmaram o liberalismo ao propor o desenvolvimento ou o progresso das nações por dois caminhos distintos. Smith enfatizou o industrialismo, fundando a escola de desenvolvimento, que ficou conhecida como Escola Clássica. Quesnay, por sua vez, fundou a Escola Fisiocrata, que pleiteava o desenvolvimento tendo atividades rurais como motores. 
Embora os Estados Unidos priorizassem o desenvolvimento pela via industrial, a Escola Fisiocrata influenciou o movimento de proteção à natureza exatamente contra um crescimento econômico que se revelou predatório. Catherine Larrère mostrou como esse movimento se dividiu em duas tendências que pleiteavam a criação de áreas para a proteção de amostras significativas ou de monumentos naturais. Seriam os Parques. Para nós, o conceito que se firmou na legislação é o de Unidade de Conservação. Nos Estados Unidos, uma corrente pleiteava a criação de parques abertos à visitação, enquanto a outra pretendia que tais Parques fossem fechados para a proteção integral da natureza. O movimento de proteção da natureza nos Estados Unidos divide-se, assim, em conservacionismo e preservacionismo, correntes que se manifestariam em todo o mundo ocidental primeiro e ocidentalizado posteriormente (LARRÈRE, 2008). O conservacionismo insere-se perfeitamente no liberalismo ao propor a proteção de áreas de especial importância ambiental e cênica para visitação que contribua para a educação. Do lado de fora delas, o crescimento econômico pode continuar desenfreado. Já o preservacionismo pleiteia a proteção de áreas ambientalmente importantes para a proteção da vida selvagem, sem a visitação de humanos. Ela pode combinar-se com o liberalismo, na medida em que o crescimento econômico destrutivo atue fora de tais áreas protegidas. Assim, existe nessa postura um viés saudosista de uma natureza virgem.

No Brasil, a Escola Clássica não exerceu influência expressiva no século XIX. Podemos dizer que ela se manifestou no projeto industrialista de Irineu Evangelista de Souza, o Barão de Mauá. A Escola Fisiocrata, ao contrário, influenciou significativamente os jovens ricos que saíam do país para estudar em Coimbra ou em Paris. Explica-se: o Brasil era dominado por uma economia rural rude e predatória, de um exponencialismo (examinaremos esse conceito adiante) exacerbado. Esses jovens ou já senhores, ao retornarem ao Brasil, passaram a defender o desenvolvimento do país pela via Rural, até porque o ruralismo predominava. Os nomes mais expressivos eram os de José Bonifácio e Joaquim Nabuco (PÁDUA, 2002). Essa tradicional linha liberal de proteção à natureza ganhou adeptos célebres, como André Rebouças, Euclides da Cunha, Alberto Torres e Luís Amaral, e desembocou na criação da Fundação Brasileira para a Conservação da Natureza, em 1958. Ela pleiteava a proteção de parcelas significativas de ambientes nativos em pontos estratégicos e, principalmente, a conservação da água.

Do Iluminismo e da Revolução Francesa também emerge o socialismo, que teve em Karl Marx e Friedrich Engels seus maiores representantes. Ambos mostraram os impactos do modo de produção capitalista nos humanos e na natureza (MARX; ENGELS, 1975; ENGELS, 1974). No geral, contudo, predominou neles a preocupação com a dimensão social. Prevalecia na época em que ambos viveram a crença em um humanismo exacerbado. De forma reducionista, entendeu-se que uma revolução comunista socializaria os meios de produção, mas não abdicaria do projeto de domínio da natureza em favor do homem. $\mathrm{Na}$ Revolução Russa de 1917, prevaleceu um projeto produtivista não muito distinto do projeto liberal de dominação da natureza. Mas o socialismo não se restringe ao marxismo, pois foram desenvolvidas propostas socialistas não marxistas.

Por fim, falta falar do anarquismo. No auge da Revolução Francesa, o socialista Robespierre acusava a oposição radical, representada pelo grupo liderado por Jacques Roux, de anarquista, emprestando a esse termo forte conotação negativa. No final de sua vida, Rousseau (1986) adotou postura análoga à do anarquismo em seu último livro. Como chamamos a atenção para a dificuldade de encontrar tipos puros, identificamos 
em Rousseau traços liberais, socialistas e anarquistas. O primeiro anarquista pensador a escrever dos impactos da economia sobre a natureza foi o norte-americano Henry David Thoreau (1817-1862) (THOREAU, 1984). Seu anarquismo, contudo, vinha contaminado pelo liberalismo radical, representado por um exacerbado individualismo e pela desobediência civil. O pensador anarquista que mais associou a questão social à ambiental foi, sem dúvida, o russo Peter Kropotkin (1842-1921).

Entre a Revolução Industrial e a Conferência de Estocolmo, as três correntes - liberalismo, socialismo e anarquismo - manifestaram-se na sua forma dura, sem preocupações maiores com os impactos de um desenvolvimento clássico ou fisiocrata sobre o meio natural. Pelo menos uma década antes da Conferência, representantes das três correntes - com as esperadas combinações entre elas - vinham já chamando a atenção para os efeitos de um crescimento veloz e desenfreado sobre a natureza. O liberalismo manifestava tal preocupação ao fundar o Clube de Roma em 1968, embora sua projeção tivesse ocorrido depois de 1972. Emergia uma nova questão. Durante a Conferência e depois dela, representantes da três correntes mantiveram suas posturas tradicionais, ou seja, continuaram a defender um crescimento exponencial, alegando que a questão ambiental era um movimento dos países ricos para congelar o desenvolvimento dos países pobres (liberais) ou um projeto da classe média desejosa de manter as desigualdades sociais ou de se rebelar contra o pagamento de impostos (socialistas e anarquistas). O exponencialismo é uma atitude que considera a natureza como um estoque de recursos para a economia e como lixeira para descarte de dejetos, podendo estar presente no liberalismo, socialismo e anarquismo.

A delegação brasileira na Conferência de Estocolmo foi presidida pelo diplomata João Augusto de Araújo Castro, que servira ao governo de João Goulart e à ditadura militar de 1964. Ele ilustra bem a dificuldade em se trabalhar com tipos ideais, pois serviu tanto a um governo socialista quanto a governos liberais reacionários. Contudo, embora liberal, ele tinha posições fortes, até certo ponto consideradas de esquerda. A postura da delegação na Conferência foi a de um marcado exponencialismo. Em um artigo, Araújo Castro assinala com clareza a posição que adotou em Estocolmo:

[...] na consideração dos problemas atinentes à preservação do meio humano, tende-se a colocar uma tônica demasiado forte nos perigos da poluição certamente graves para os países altamente industrializados, quando a maior parcela do planeta ainda vive num estágio de pré-contaminação ou, em outras palavras, ainda não teve a oportunidade de ser poluído. Duas terças partes da humanidade estão muito mais ameaçadas pela fome e pela penúria do que pelos males da poluição. Por isso mesmo, causam apreensões as recentes declarações do senhor McNamara - contraditadas pelo Brasil no Conselho Econômico Social - de que o Banco Mundial doravante não autorizará qualquer projeto de desenvolvimento econômico sem uma avaliação minuciosa de eventuais repercussões sobre o ambiente. É claro que os países em desenvolvimento não quererão incorrer nos mesmos erros em que incorreram os países altamente industrializados, mas é evidente que não poderíamos aceitar a ressurreição, em pleno século XX, da teoria do selvagem feliz, de Rousseau, que deu sabor e colorido a todo romantismo francês. "Não deixem acontecer com suas cidades o que aconteceu com Nova York". "Conservem suas belas praias". São frases essas constantemente marteladas nos tímpanos dos representantes dos países em desenvolvimento. Ora, esses países em desenvolvimento partem da premissa de que qualquer programa adequado para a preservação do meio humano deve ter em linha de conta os fatores básicos do desenvolvimento, já que o subdesenvolvimento representa, por si só, uma das piores formas de poluição do ambiente. (ARAÚJO CASTRO, 1972). 
Depois da Conferência, apareceram muitas vozes de marxistas condenando o movimento de proteção da natureza. O mais conhecido no Brasil foi o português João Bernardo, que publicou um manifesto antiecológico, mas muitas outras vozes se somaram à dele (BERNARDO, 1979; TIBALDI, 1980; FAIVRET; MISSIKA; WOLTON, 1980; SOUZA; AMARAL VIEIRA,1984; ALPHANDÉRY; BITOUN; DUPONT, 1992). O pronunciamento de um marxista também revelou resistência conservadora ao movimento de defesa do ambiente. Foi o de Gildo Magalhães:

Não há por que retrocedermos historicamente: o homem conquistará cada metro quadrado útil do planeta e depois irá ao espaço [...]; para minimizar os efeitos depressivos do capitalismo, é preciso ser antiecológico, inclusive é preciso exaurir todas as reservas de energia conhecidas o mais rapidamente possível, pois só assim serão gerados os recursos para descobrir novas fontes de energia, necessárias para nossa expansão. (MAGALHÃES, 1984).

Do lado anarquista no Brasil, Maurício Tragtenberg viu os movimentos de defesa do meio ambiente como manifestações pequeno-burguesas de pessoas que não queriam pagar impostos (TRAGTEMBERG, 1984).

Houve mudanças gradativas entre os liberais no pós-Conferência, e a mais expressiva foi a manifestada no Clube de Roma, já mencionado como uma das forças promotoras da Conferência. Tratava-se de uma associação de empresários que buscou a assessoria de estudiosos, encomendando-lhes livros, entre os quais o mais conhecido foi Limites do crescimento, mas não o único (MEADOWS et al., 1973; MESAROVIC; PESTEL, 1975).

Entre os socialistas, emergiu uma plêiade de pensadores que empreenderam uma crítica radical ao modo de produção capitalista não apenas na sua dimensão social, mas também em suas relações com a natureza. O preço pago por eles foi o banimento ou o autoafastamento dos partidos comunistas. Alguns nem pertenciam aos quadros de um partido; apenas revelavam postura progressista, o que facilitou a apresentação de suas obras. Os mais expressivos pensadores progressistas que incorporaram a questão ambiental de forma inovadora às suas reflexões foram Rudolf Bahro, Michel Bosquet (pseudônimo de André Gorz), Jean-Pierre Dupuy, Ivan Illich, Dominique Simonnet e Laura Conti (BAHRO, 1980; BOSQUET, 1976; DUPUY, 1980). No campo da economia, o novo paradigma irrompeu nos trabalhos de Schumacher, Georgescu-Roegen, Ignacy Sachs, Herman Daly e Richard Wilkinson, para só citar os mais conhecidos (SCHUMACHER, 1979; GEORGESCU-ROEGEN, 1971; SACHS, 1986a, 1986b; DALY, 1984; WILKINSON, 1974). Essa linha de pensamento ficou conhecida como ecologismo. Se cabem, neste escrito, posicionamentos pessoais, o autor deste texto filiou-se a essa linha de pronto, fascinado pelas reflexões de seus representantes, e pretendeu expressá-la na região em que vive por meio de pensamento, ação e escritos.

No anarquismo, os nomes mais representativos foram os de Murray Bookchin e Roberto Freire (BOOKCHIN, 1978; FREIRE, 1992).

Das três correntes anteriores e posteriores à Conferência de Estocolmo, o exponencialismo liberal e o socialista continuaram a vigorar. Na Conferência Rio-92, Fidel Castro ainda sustentava que a espécie mais ameaçada de extinção era o homem. João Almino escreveu artigos resistindo às propostas de incorporação da questão emergente ao socialismo ou buscando efetuar uma tipologia confusa das correntes ideológicas pós-Estocolmo (ALMINO, 1990, 2004). 
De forma difusa, sem nomes expressivos, o liberalismo resistiu a mudanças de pensamento, mas também avançou dentro da ONU, com a Comissão Brundtland. Promovendo audiências públicas em todo o mundo, a Comissão publicou, em 1987, o livro Nosso futuro comum, com a proposta de desenvolvimento sustentável ou simplesmente sustentabilidade (COMISSÃO MUNDIAL SOBRE MEIO AMBIENTE E DESENVOLVIMENTO, 1988). O autor deste trabalho esteve presente à audiência pública realizada em São Paulo e, sem saber com clareza sobre o que se discutia, ofereceu como contribuição um texto em que expressava suas convicções ecologistas, aliás incluído nas referências do livro. Mais uma vez, reforça-se a percepção de que não existem tipos ideais. O conceito de sustentabilidade é liberal, mas incorpora questões caras ao socialismo, como distribuição de renda, saneamento básico, redução das desigualdades sociais, direitos universais do cidadão etc. Tanto que desenvolvimento sustentável se tornou hoje um conceito vulgarizado pela direita e pela esquerda. O conceito norteou a Conferência Rio-92, Rio+20 e todas as conferências temáticas patrocinadas pela ONU. Na Rio+20, buscou-se em vão substituir o conceito de sustentabilidade pelo de economia verde. Cabe observar que, na Conferência Rio-92, a Cúpula dos Povos, reunindo tendências progressistas, efetuou cerradas críticas à proposta de desenvolvimento sustentável, porém o conceito acabou por triunfar.

Socialistas que não aceitavam mais a tradicional postura exponencialista e que repudiavam a postura liberal de desenvolvimento sustentável sem a devida crítica avançaram para a concepção de Justiça Ambiental, hoje um movimento com fortes alicerces no Brasil. Por outro lado, Michael Löwy formulou o ecossocialismo, que não se propagou tanto quanto Justiça justiça Ambientalambiental (LÖWY, 2014).

O quadro se torna mais complexo quando se consideram as combinações da questão ambiental com as diversas doutrinas religiosas e os movimentos feminista (ecofeminismo), de gênero e de raça; ainda mais se levarmos em conta que as posturas preservacionistas, conservacionistas e ecologistas perduram em nichos. $\mathrm{O}$ veganismo conserva muito do preservacionismo e é defendido por pessoas liberais e socialistas. O conservacionismo continua presente em orientações liberais que defendem a criação de unidades de conservação, por exemplo. Por outro lado, as teorias da Justiça Ambiental e do ecossocialismo não substituíram de todo o ecologismo do qual ambas derivam. O autor destas linhas ainda se insere parcialmente em tal tendência desde os anos de 1970, entendendo-a como a primeira utopia planetária até pouco tempo (SOFFIATI, 2007).

Mas deve-se reconhecer que o liberalismo está dando as cartas. Existe uma tendência liberal radical que se expandiu depois da queda da União Soviética e dos países socialistas europeus entre 1989-1991. Tal queda foi saudada como o fim da história e abriu caminho para o avanço do neoliberalismo (FUKUYAMA, 1992). O Estado de bem-estar social, que combinou liberalismo e socialismo, está sob o fogo cerrado do neoliberalismo. Contudo, as condições objetivas evidenciam cada vez mais que o Estado, mesmo no mundo liberal, não pode reduzir-se a dimensões mínimas. Com tanto problemas sociais, a pandemia causada pelo novo coronavírus (Sars-CoV-2) e a crise ambiental exigem o retorno de um Estado de bem-estar agora socioambiental.

\section{Referências}

ALMINO, J. Ideias de naturezas mortas. Jornal do Brasil, Rio de Janeiro, 11 nov. 1990.

ALMINO, J. Naturezas mortas. Rio de Janeiro: Francisco Alves, 2004. 
ALPHANDÉRY, P.; BITOUN, P.; DUPONT, Y. O equívoco ecológico: riscos políticos. São Paulo: Brasiliense, 1992.

ARAÚJO CASTRO, J. A. O congelamento do poder mundial. Revista Brasileira de Estudos Políticos, Belo Horizonte, n. 33, p. 7-30, 1972.

BAHRO, R. A alternativa: para uma crítica do socialismo real. Rio de Janeiro: Paz e Terra, 1980.

BERNARDO, J. O inimigo oculto: manifesto antiecológico. Lisboa: Afrontamento, 1979.

BOOKCHIN, M. Por una sociedad ecológica. Barcelona: Gustavo Gili, 1978.

BOSQUET, M. Ecologia e política. Lisboa: Notícias, 1976.

COMISSÃO MUNDIAL SOBRE MEIO AMBIENTE E DESENVOLVIMENTO. Nosso futuro comum. Rio de Janeiro: Fundação Getúlio Vargas, 1988.

DALY, H. A economia do século XXI. Porto Alegre: Mercado Aberto, 1984.

DUPUY, J.-P. Introdução à crítica da ecologia política. Rio de Janeiro: Civilização Brasileira, 1980.

ENGELS, F. O papel do trabalho na transformação do macaco em homem: dialéctica da natureza. Lisboa: Presença; Rio de Janeiro: Martins Fontes, 1974. (Data de cólofon).

FAIVRET, J.-P.; MISSIKA, J.-L.; WOLTON, D. L’Illusion écologique. Paris: Du Seuil, 1980.

FREIRE, R. A farsa ecológica. Rio de Janeiro: Guanabara Koogan, 1992.

FUKUYAMA, F. O fim da história e o último homem. Rio de Janeiro: Rocco, 1992.

GEORGESCU-ROEGEN, N. The entropy law and the economic process. Cambridge: Harvard, 1971.

LARRÈRE, C. Duas filosofias de proteção à natureza. In: SANTOS, A. C. Filosofia e natureza: debates, embates e conexões. Aracaju: Universidade Federal de Sergipe, 2008.

LÖWY, M. O que é o ecossocialismo. 2. ed. São Paulo: Cortez, 2014.

MAGALHÃES, G. A anti-ecologia necessária. Socialismo e Democracia, São Paulo, n. 1, 1984.

MARX, K.; ENGELS, F. Cartas sobre las ciencias de la naturaleza y las matemáticas. Barcelona: Anagrama, 1975.

MEADOWS, D. H. et al. Limites do crescimento. São Paulo: Perspectiva, 1973.

MESAROVIC, M.; PESTEL, E. Momento de decisão: o segundo informe ao Clube de Roma. Rio de Janeiro: Agir, 1975.

PÁDUA, J. A. Um sopro de destruição: pensamento político e crítica ambiental no Brasil escravista (1786-1888). Rio de Janeiro: Jorge Zahar, 2002.

ROUSSEAU, J.-J. Os devaneios do caminhante solitário. Brasília: EdUnB, 1986.

SACHS, I. Ecodesenvolvimento: crescer sem destruir. São Paulo: Vértice, 1986a.

SACHS, I. Espaços, tempos e estratégias do desenvolvimento. São Paulo: Vértice, 1986b.

SCHUMACHER, E. F. O negócio é ser pequeno. Rio de Janeiro: Zahar, 1979.

SOFFIATI, A. Ecologismo: a primeira utopia planetária. Morus: Utopia e Renascimento, Campinas, n. 4, 2007. SOUZA, A. B.; AMARAL VIEIRA, R. A. Poluição, alienação e ideologia. Rio de Janeiro: Achiamé, 1984. THOREAU, H. D. Walden ou a vida nos bosques. São Paulo: Global, 1984.

TIBALDI, E. Antiecologia. Barcelona: Anagrama, 1980.

TRAGTEMBERG, M. Ecologia versus capitalismo. Economia e Desenvolvimento, São Paulo, n. 2, 1984.

WILKINSON, R. Pobreza e progresso: um modelo ecológico de desenvolvimento econômico. Rio de Janeiro: Zahar, 1974.

SOBRE O AUTOR

Arthur Soffiati; SOFFIATI, A. Universidade Federal Fluminense (UFF). Professor Associado I da Universidade Federal Fluminense, em Campos dos Goytacazes (UFF/Campos). 


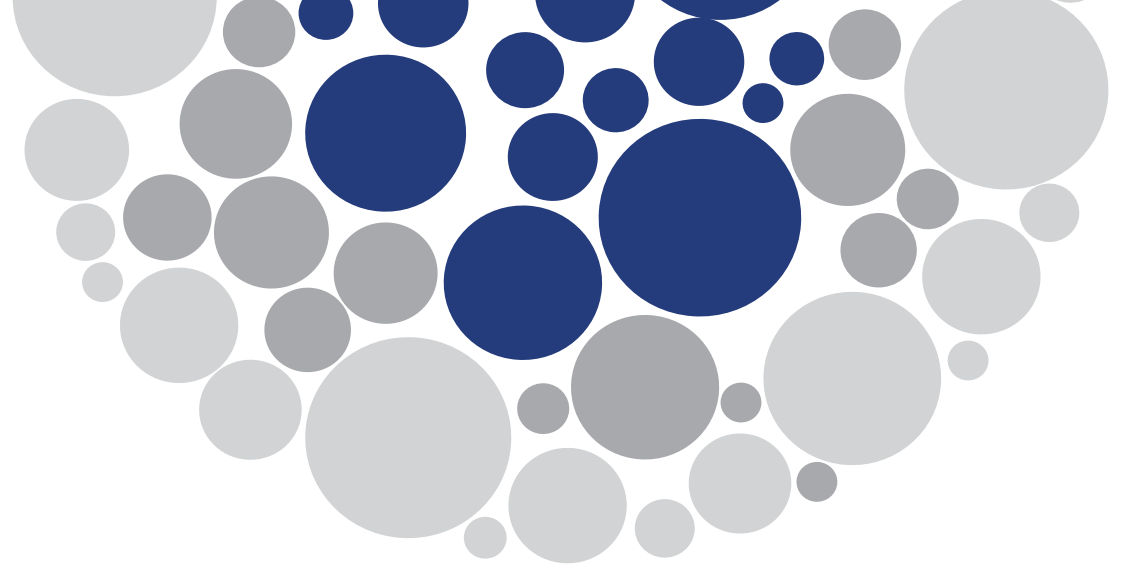

\title{
Comportamento espaço-temporal do oxigênio dissolvido e dos coliformes termotolerantes na região do médio/baixo curso do rio Paraíba do Sul, Norte Fluminense, Rio de Janeiro, Brasil
}

\begin{abstract}
Bruna Almeida Ribeiro ${ }^{a}$, Adriana Filgueira Leite ${ }^{b}$
a Universidade Federal Fluminense (UFF), Campos dos Goytacazes (RJ), Brasil. E-mail: bruna_almeida4@yahoo.com.br ${ }^{\mathrm{b}}$ Departamento de Geografia, Universidade Federal Fluminense (UFF), Campos dos Goytacazes (RJ), Brasil. E-mail: adrianafilgueiraleite@id.uff.br
\end{abstract}

\section{Introdução}

Nos últimos anos, os recursos hídricos vêm sendo deteriorados pela ação do homem, resultando em prejuízos na qualidade e na disponibilidade da água. Neste sentido, é notória a necessidade do monitoramento da qualidade da água, de modo a garantir que seus usos múltiplos não sejam comprometidos e que os impactos negativos sobre a sua qualidade sejam minimizados.

A qualidade da água é um fator indispensável para a sua utilização, visando atender às necessidades sociais e às atividades econômicas (urbanas, agrícolas e industriais). Esses usos têm sofrido restrições significativas em função de danos causados aos rios pelas intervenções humanas, as quais alteram a qualidade e a quantidade de água disponível para a utilização do homem. Todos esses dados apontam para uma realidade alarmante, mas que, apesar disso, tem sido muito menos discutida do que seria necessário em 
âmbito mundial, que é o fato de o planeta estar caminhando para uma tendência geral de escassez hídrica.

Essa escassez não é exatamente a falta da água no sentido pleno do termo, uma vez que, por questões físico-químicas, suas proporções na Terra são praticamente inalteráveis. Isso ocorre porque a água se movimenta no planeta por meio de um ciclo fechado - o ciclo hidrológico -, no qual esse elemento não sofre perdas nem ganhos em termos quantitativos. Nesse sentido, a escassez hídrica pode ocorrer sob duas formas: a primeira corresponde à restrição da disponibilidade de água para os usos múltiplos e pode ser expressa por meio da redução das vazões fluviais e pela necessidade de se fazer perfurações cada vez mais profundas nos solos para a instalação de poços, em razão do rebaixamento progressivo dos níveis freáticos; a segunda corresponde à perda da qualidade da água. Trata-se da sua deterioração a um nível tal de magnitude, que se torna impossível revertê-la por meio do uso de tecnologias.

De modo geral, as principais fontes de contaminantes dos recursos hídricos são os esgotos - em especial pelo fato de que no Brasil a maior parte deles é despejada nos corpos hídricos sem tratamento prévio -, os rejeitos industriais, os rejeitos de mineração, os agrotóxicos utilizados na agricultura e o chorume proveniente dos lixões.

A bacia hidrográfica do rio Paraíba do Sul, apesar de não estar entre as maiores do território brasileiro, pode ser considerada uma das mais importantes por estar localizada entre os três estados de maior pujança econômica nacional: São Paulo, Minas Gerais e Rio de Janeiro. Nesse sentido, mesmo que o rio em questão não integre a paisagem de nenhuma das regiões metropolitanas dos estados mencionados, ele perpassa diversos municípios de pequeno e médio portes que compõem o principal eixo industrial do país, posicionando-se entre São Paulo e Rio de Janeiro, ao longo da BR-116, sendo, portanto, receptor da maior parte dos efluentes industriais e urbanos, assim como da mineração e da agricultura, produzidos em contextos mais pontuais no âmbito da bacia.

Considerando que os níveis de tratamento de esgoto na bacia do rio Paraíba do Sul como um todo ainda são bastante incipientes quando se levam em conta os padrões internacionais de qualidade, ao alcançar a região do baixo curso, que é objeto de análise deste estudo, a água do rio em questão já se encontra bastante comprometida. A esse comprometimento se somam o fato de que a região mencionada apresenta um quadro de escassez hídrica, que se expressa por meio do declínio das vazões desse rio, e de que a sua população praticamente dobrou entre as décadas de 1960 e 2010 (LEITE, 2015).

Nesta conjuntura, verifica-se que os estudos de qualidade da água, que é um dos indicadores da sua disponibilidade no ambiente, conforme já mencionado, ganham especial relevância no contexto de escassez hídrica que se construiu historicamente na região do baixo rio Paraíba do Sul. Do ponto de vista da gestão dos recursos hídricos, estudos dessa natureza tendem a se tornar cada vez mais imprescindíveis, na medida em que os gestores necessitam de dados sobre a qualidade da água para planejar e implementar políticas públicas relacionadas à coleta, tratamento e descarte do esgoto, assim como de captação, tratamento e distribuição da água nos ambientes urbanos e rurais. Contudo, do ponto de vista geográfico, tais estudos tendem a ganhar centralidade no contexto da bacia mencionada, pois, ainda que o declínio das vazões a alcance como um todo, ele é mais crítico em determinados segmentos, a exemplo da região do médio/baixo curso. Considerando as históricas assimetrias de poder evidenciadas entre os diversos setores econômicos que se encontram ali representados, constata-se que as prioridades dos usos 
das águas tenderão a ser cada vez mais determinadas pelos grupos que são hegemônicos (LEITE, 2017).

Diante do exposto, este estudo se propõe a fazer uma análise da qualidade da água do rio Paraíba do Sul por meio dos parâmetros oxigênio dissolvido e coliformes termotolerantes no segmento que corresponde ao seu médio/baixo curso, localizado na região norte do estado do Rio de Janeiro, de tal modo a avaliar o seu comportamento espaço-temporal entre os anos de 2014 e 2019.

\section{Materiais e métodos}

\section{1 - Área de estudo}

A área onde o presente estudo foi realizado corresponde ao médio/baixo curso do rio Paraíba do Sul, no trecho compreendido pelos municípios de São Fidélis e Campos dos Goytacazes, ambos localizados no Norte Fluminense, Rio de Janeiro, Brasil (Figura 1).

No município de São Fidélis, a área que margeia o rio Paraíba do Sul é composta por relevo colinoso, e as planícies se encontram parcialmente confinadas em suas margens pelas encostas das colinas. O rio apresenta padrão entrelaçado e, conforme esperado,

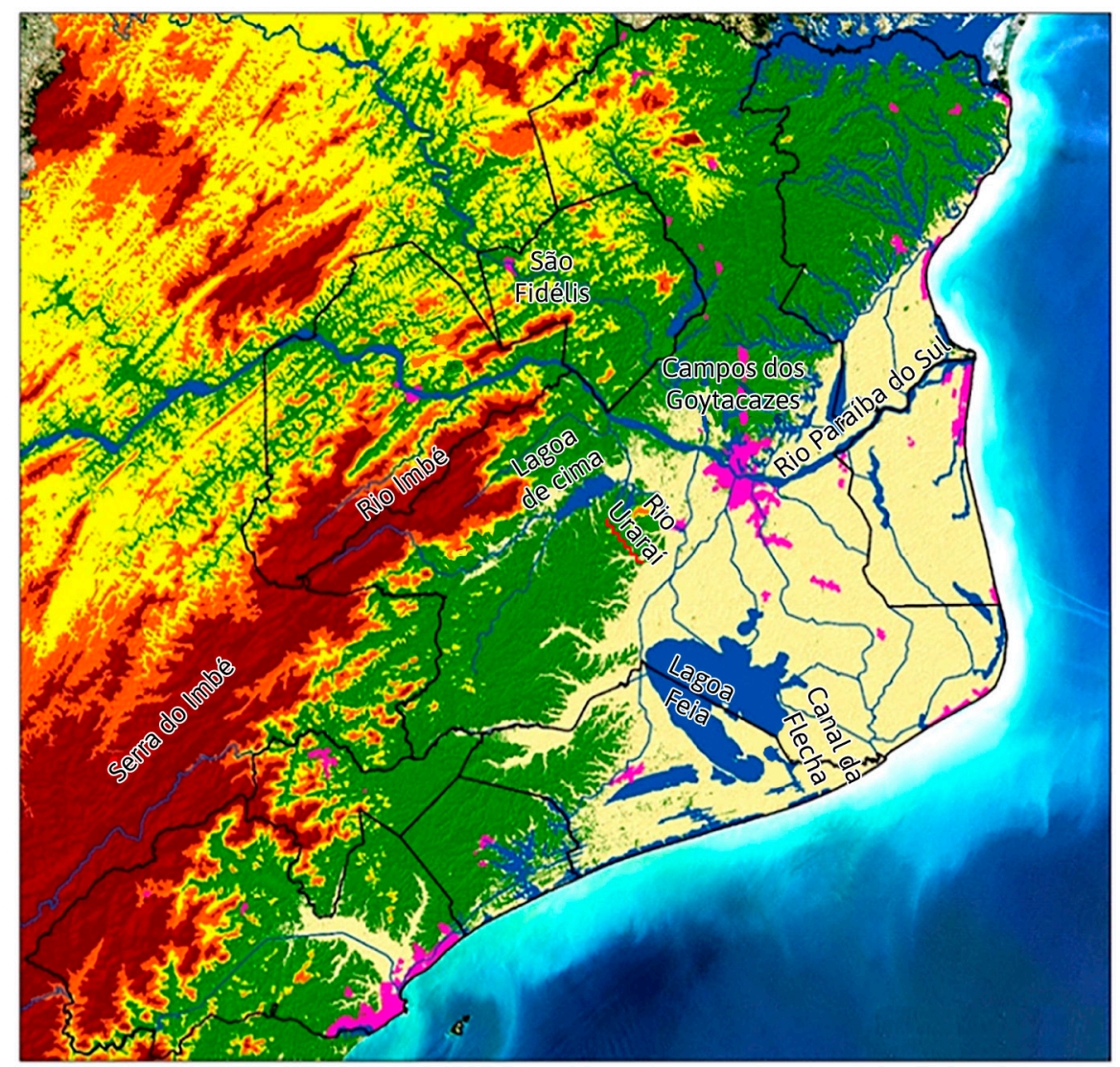

Domínios morfoesculturais da região norte fluminense

Legenda

$\sim 3$ Região norte fluminense

4 Ocupação urbana do norte fluminense

Corpos hídricos

Rios e canais

Lagos e lagoas

Domínios morfoesculturais

(3) 0-10 m - planície fluviomarinha

(4) $11-100 \mathrm{~m}$ - tabuleiros

(3) $101-200 \mathrm{~m}$ - morros

$3201-400 \mathrm{~m}$ - serras isoladas ou locais

$\checkmark$ >401 m - serras escarpadas

Retângulo envolvente

Norte

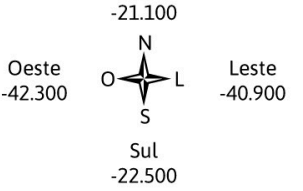

Sistema de coordenadas: GCS WGS 1984 Datum: WGS 1984

Unidades: graus decimais 1:500.00

Fonte: ALVES \& MIRO, 2015; ALVES et al, 2015; IBGE, 2013; INPE, 2015.

Elaboração: Walace Alves Nicking a partir do Centro de Informação e Dados de Campos - CIDAC - 2015

Figura 1 - Mapa de localização da região do médio/baixo curso do rio Paraíba do Sul (Norte Fluminense, Rio de Janeiro, Brasil). Fonte: NICKNIG (2016). 
uma abundante presença de ilhas ao longo do seu curso. Barras arenosas também são visíveis nos períodos de estiagem e de seca, quando se verifica uma redução significativa das vazões e dos níveis fluviais do Paraíba, como foi o caso da seca ocorrida entre os anos de 2014 e 2016. Ainda que a formação de barras e ilhas seja um processo natural concernente à dinâmica fluvial que caracteriza os ambientes com as características geomorfológicas que ali se encontram, verifica-se que a sua proliferação foi intensificada pelo desmatamento em larga escala desde o início da colonização, em especial nas áreas de encostas, na medida em que os sedimentos transportados pelos processos erosivos convergem para os corpos hídricos.

No município de Campos dos Goytacazes, pelo fato de o relevo apresentar-se predominantemente plano, a área que constitui as planícies do rio Paraíba do Sul não apresenta confinamento de suas margens. A margem esquerda situa-se sobre tabuleiros constituídos por sedimentos terciários da Formação Barreiras. Nessa margem, encontra-se também o ponto de deságue do rio Muriaé, que é o principal tributário do Paraíba nesse trecho da bacia. No que se refere à margem direita, constata-se que ela está posicionada sobre sedimentos quaternários de origem fluviomarinha, os quais foram ali depositados após sucessivos episódios de transgressões e regressões marinhas. O rio Paraíba do Sul, nesse segmento, apresenta um padrão de canal misto, que associa feições meandrantes e entrelaçadas.

É importante destacar que as intervenções feitas no rio Paraíba do Sul durante o século XX nos segmentos posicionados a montante da área estudada, especialmente a implantação de diversas hidrelétricas e de uma transposição de águas, exerceram impacto nos seus processos de sedimentação e, consequentemente, na formação de ilhas e barras fluviais em ambos os segmentos que são objeto desta análise. Isso ocorreu em resposta à redução das vazões fluviais promovida pela regularização do rio, que foi instituída pela gestão dos reservatórios (LEITE, 2019). Esse é um fator importante a ser levado em conta na análise deste trabalho, pelo fato de que a eficiência de um rio em promover a diluição dos esgotos que convergem para ele é fortemente influenciada pelo comportamento da vazão fluvial.

Outras intervenções de grande magnitude ocorreram também na área do entorno do rio Paraíba do Sul, no trecho compreendido entre Campos dos Goytacazes e São João da Barra. Em sua origem, a região como um todo se caracterizava por apresentar uma extensa superfície de brejos e lagoas (tanto de água doce quanto de água salgada), perenes e temporárias, que, desde o período colonial, passou por um amplo processo de drenagem, o qual ocorreu para que houvesse a ampliação das áreas a serem utilizadas pela agroindústria canavieira, a atividade econômica mais importante da região de meados do século XVIII (LAMEGO, 2007) até a década de 1980, momento em que entrou em declínio. A drenagem das superfícies foi feita por meio da implantação de uma extensa rede de canais artificiais, que, atualmente, apresenta $1.293 \mathrm{~km}$ de extensão (MENDONÇA, 2014). Goudie e Viles (2016) apontam que o processo de drenagem de superfícies brejais causa o rebaixamento dos níveis freáticos, principalmente em solos orgânicos, como é o caso de boa parte dos solos existentes na margem direita do rio Paraíba do Sul, que são compostos por turfas (FRANCHI et al., 2006). Considerando que os lençóis freáticos são responsáveis por manter a perenidade dos rios, verifica-se que o seu rebaixamento também foi responsável pela redução das vazões fluviais do rio Paraíba do Sul na região abrangida por seu médio/baixo curso (LEITE, não publicado). 


\section{2 - Levantamento e análise dos dados de qualidade da água}

Para a realização deste estudo, foram utilizados dados de oxigênio dissolvido (parâmetro físico-químico) e de coliformes termotolerantes (parâmetro biológico), provenientes de dois pontos da rede de monitoramento de qualidade da água do Instituto Estadual do Ambiente (INEA), localizados, respectivamente, em São Fidélis e em Campos dos Goytacazes (Figura 2), entre os anos de 2014 e 2019. Os dados em questão, assim como os métodos laboratoriais utilizados na sua determinação, encontram-se disponíveis no site da instituição (INSTITUTO ESTADUAL DO AMBIENTE, 2019). A seleção desses pontos teve por objetivo fazer uma comparação da qualidade da água entre o médio e o baixo curso do rio Paraíba do Sul. Para tanto, foram feitas análises espaço-temporais dos parâmetros ora mencionados. Assim sendo, os dados provenientes de cada ponto amostral considerado neste trabalho foram tabelados, submetidos a análises estatísticas de média, desvio padrão e coeficiente de variação e comparados entre si.

\section{Resultados e discussão}

\section{1 - Oxigênio dissolvido}

O oxigênio é um gás cuja principal origem é a atmosfera. Nesse sentido, Von Sperling (2014) afirma que as águas constituem ambientes bastante pobres em oxigênio, em virtude da

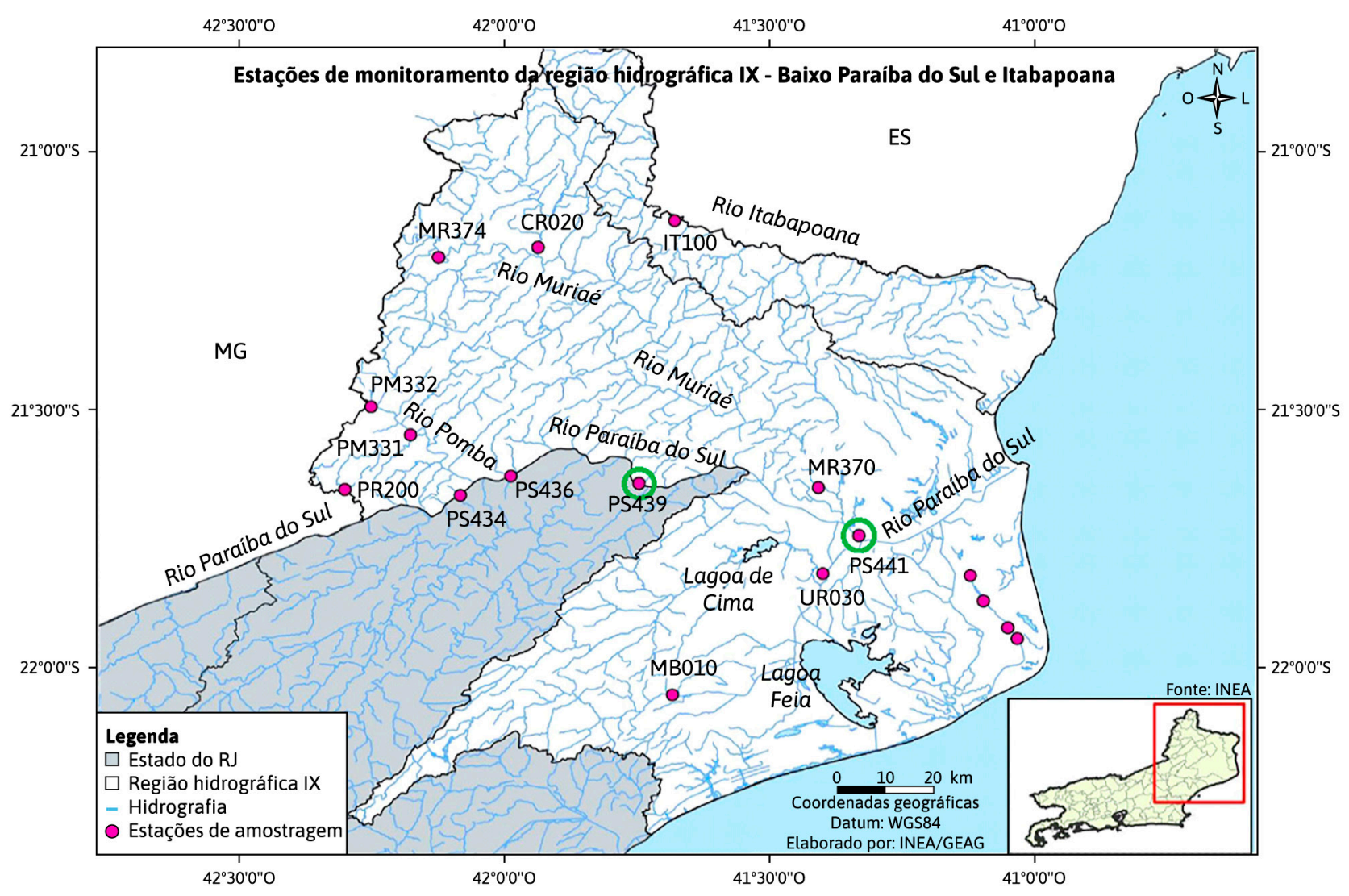

Figura 2 - Pontos de amostragem da rede de monitoramento de qualidade da água realizado pelo INEA. Os pontos que apresentam os círculos de cor verde correspondem aos locais cujos dados foram analisados neste estudo.

Fonte: Instituto Estadual do Ambiente (2019). 
sua baixa solubilidade. Enquanto no ar a sua concentração é da ordem de $270 \mathrm{mg} / \mathrm{L}$, na água, em condições normais de temperatura e pressão, a sua concentração se reduz para aproximadamente $9 \mathrm{mg} / \mathrm{L}$.

Von Sperling (2014) afirma também que a reaeração atmosférica é frequentemente o principal fator responsável pela introdução de oxigênio no meio líquido. Neste sentido, a transferência do oxigênio da fase gasosa para a fase líquida ocorreria basicamente por meio de dois mecanismos: a difusão molecular e a difusão turbulenta. No que se refere à difusão molecular, trata-se do processo que predomina nos corpos hídricos cujas águas apresentam baixas velocidades de deslocamento, como no caso dos ambientes lacustres. Consiste na tendência que as substâncias têm de se espalhar uniformemente por todo o espaço disponível, sendo, portanto, bastante lento e requerendo muito tempo para que um gás atinja as camadas mais profundas. $O$ vento é um fator que age de tal modo a acelerar a ação desse mecanismo nos contextos em que ele prevalece. Quanto à difusão turbulenta, considerada mais eficiente, refere-se ao mecanismo que promove a reaeração das águas a partir dos processos de criação de interfaces e de sua respectiva renovação. Tal fenômeno é determinado pelas mais altas velocidades das correntes, uma vez que propiciam condições de alta turbulência da água. Esse seria o caso, por exemplo, de um rio com menor profundidade e com corredeiras.

Segundo Esteves e Furtado (2011), as concentrações de oxigênio dissolvido são variáveis verticalmente na coluna d'água, sendo mais altas nas superfícies dos corpos hídricos e ínfimas nos leitos fluviais e lacustres. Essa seria uma consequência do fato de que a difusão do oxigênio dentro de um corpo de água se dá, principalmente, pelo seu transporte em massas d'água (por difusão turbulenta), uma vez que a difusão molecular é insignificante. Contudo, verifica-se também que, além de as superfícies dos corpos hídricos estarem em contato direto com a atmosfera, sendo, portanto, mais favorecidas pelos mecanismos de aeração, há variações verticais na velocidade da corrente fluvial e, consequentemente, da turbulência da água. De acordo com Summerfield (1991), a velocidade do fluxo da corrente é influenciada pela declividade, assim como pela rugosidade e pela forma da seção transversal do canal. Os canais naturais quase invariavelmente têm superfícies rugosas que induzem perdas significativas de energia de atrito e causam uma redução na velocidade do fluxo, especialmente perto do limite do canal (bordas e leito).

Quanto à sua influência sobre a qualidade da água, constata-se, de acordo com Von Sperling (2018), que o oxigênio dissolvido é de essencial importância para os organismos aeróbios. Durante a estabilização da matéria orgânica, as bactérias fazem uso do oxigênio nos seus processos respiratórios, podendo vir a causar uma redução da sua concentração no meio. A matéria orgânica corresponde a todo o material de origem vegetal ou animal produzido no próprio ambiente aquático (autóctone) ou introduzido nele por meio de despejos ou carreamento, ou seja, pelo arraste por água de chuva (alóctone) (COMPANHIA AMBIENTAL DO ESTADO DE SÃO PAULO, 2021). A matéria orgânica proveniente dos esgotos se apresenta sob duas formas: em suspensão (ou particulada), que tende a sedimentar no corpo d'água, formando o lodo de fundo; e dissolvida (ou solúvel), que, conjuntamente com a matéria suspensa de pequenas dimensões (dificilmente sedimentável), permanece na massa líquida. Dependendo da magnitude do consumo do oxigênio dissolvido pelas bactérias, podem vir a morrer diversos seres aquáticos, inclusive os peixes. Caso o oxigênio seja totalmente consumido, são produzidas condições anaeróbias, com possível geração de maus odores. Por esse motivo, o oxigênio dissolvido 
é o principal parâmetro de caracterização dos efeitos da poluição das águas por despejos orgânicos (VON SPERLING, 2018).

Os teores de oxigênio dissolvido também expressam a capacidade de autodepuração dos corpos hídricos. O potencial de autodepuração refere-se à habilidade que os ambientes aquáticos têm de estabilizar a matéria orgânica que ali se encontra. Esse fenômeno ocorre à medida que as bactérias consomem o oxigênio dissolvido durante o processo de decomposição da matéria orgânica, convertendo-a em substâncias como gás carbônico e água (estabilização), que são estáveis e não prejudiciais ao ambiente do ponto de vista ecológico (VON SPERLING, 2018). Sendo assim, ele também é fortemente influenciado pelas vazões fluviais, pois, conforme já mencionado, os processos de aeração e reaeração dos corpos hídricos são determinados pela turbulência das correntes. Nesse sentido, enquanto baixas vazões determinam taxas mais baixas de aeração, o oposto acontece quando as vazões são altas.

Contudo, o conceito de autodepuração apresenta certa relatividade, pois um corpo d'água pode ser considerado depurado sob determinado aspecto e não o ser em outros, a exemplo dos padrões de salubridade, apresentando, assim, organismos patogênicos. Do ponto de vista prático, deve-se considerar que um corpo d'água ou trecho de rio está depurado quando suas características não são mais conflitantes com o tipo de uso que para ele se encontra previsto em lei (VON SPERLING, 2018).

No que se refere aos padrões considerados aceitáveis para o oxigênio dissolvido, percebe-se que a sua concentração média ao nível do mar é de 9,2 mg/L. Assim sendo, enquanto as concentrações inferiores a esse valor são indicativas da presença de matéria orgânica nos corpos hídricos, originária primordialmente de esgotos, as superiores constituem indícios do elevado acúmulo de algas (que realizam fotossíntese e produzem oxigênio puro). Quando os valores de oxigênio dissolvido se encontram em torno de 4-5 mg/L, os peixes mais exigentes morrem, e quando alcança o valor de $2 \mathrm{mg} / \mathrm{L}$, inviabiliza-se a existência de todos os peixes, incluindo os mais tolerantes à baixa oxigenação (VON SPERLING, 2018). Quanto aos padrões especificados pela Resolução CONAMA 357/2005 (BRASIL, 2005), que é a norma que regulamenta os padrões de qualidade da água utilizados no Brasil, constata-se que, para as águas doces, as concentrações de oxigênio dissolvido nas águas de classe 1 não devem ser inferiores a $6 \mathrm{mg} / \mathrm{L}$; nas águas de classe 2 , não devem ser inferiores a $5 \mathrm{mg} / \mathrm{L}$; e nas águas de classe 3 , não devem ser inferiores a $4 \mathrm{mg} / \mathrm{L}^{1}$. No que diz respeito ao rio Paraíba do Sul, verifica-se que o seu enquadramento é de classe 2 em São Fidélis e de classe 3 em Campos dos Goytacazes (COMITÊ DE INTEGRAÇÃO DA BACIA HIDROGRÁFICA DO RIO PARAÍBA DO SUL, 2020).

No que concerne aos dados analisados neste estudo, observa-se que, em ambos os pontos de amostragem do rio Paraíba do Sul, localizados nos municípios de São Fidélis e Campos dos Goytacazes, são identificadas concentrações inferiores a 9,2 mg/L de oxigênio dissolvido, as quais são indicativas da presença de esgotos nas águas. Trata-se de um resultado que já poderia ser esperado, considerando que nenhum dos municípios mencionados coleta e trata $100 \%$ do esgoto que produz (Figura 3). Contudo, apesar disso, não foram ali detectadas concentrações baixas o bastante que pudessem

${ }^{1}$ De acordo com a Resolução CONAMA 357/2005, as águas doces correspondem às águas com salinidade igual ou inferior a $0,5 \%$ e são divididas em classe especial e classes 1, 2 e 3 . Quanto ao uso para abastecimento humano, as águas da classe especial para serem consumidas necessitam passar somente por desinfecção; as de classe 1, por tratamento simplificado; as de classe 2, por tratamento convencional; e as de classe 3, por tratamento convencional ou avançado. 


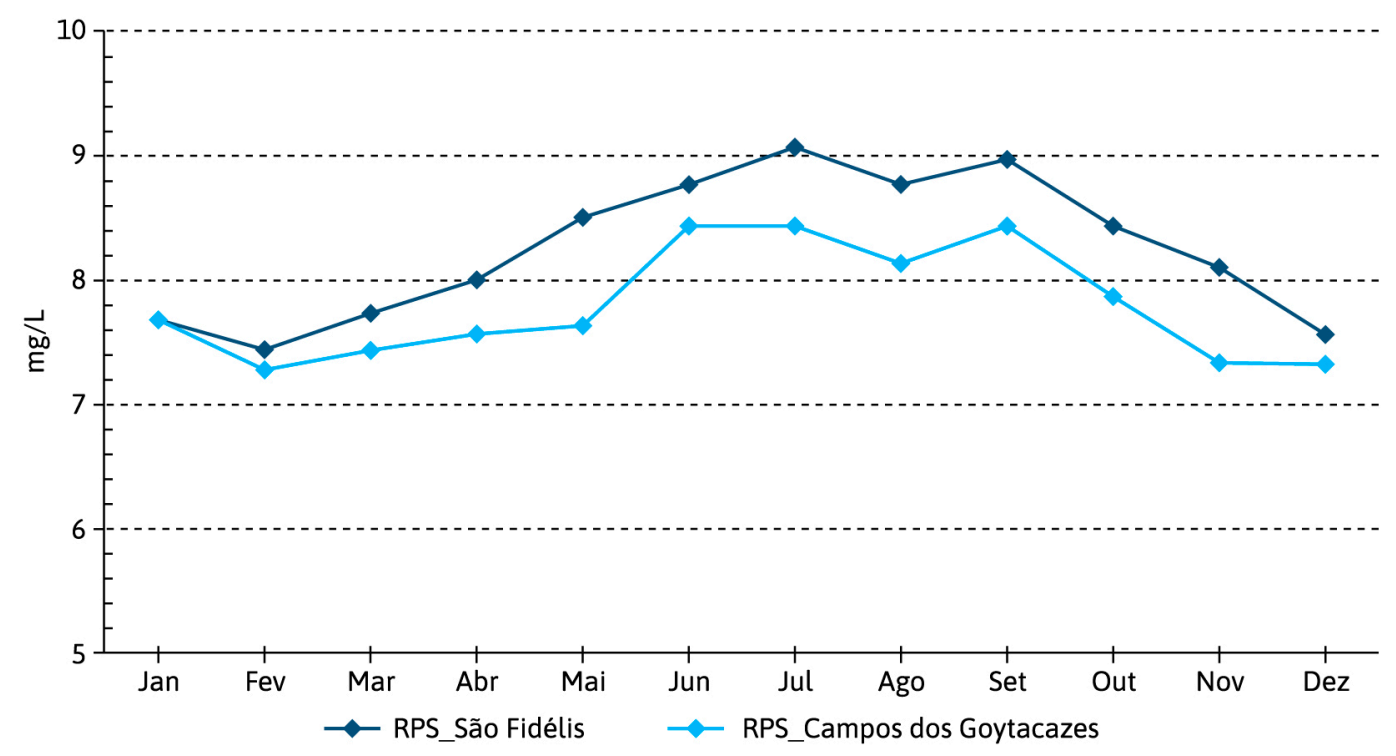

Figura 3 - Comportamento sazonal do oxigênio dissolvido (em $\mathrm{mg} / \mathrm{L}$ ) nos pontos amostrais do rio Paraíba do Sul (RPS), localizados nos municípios de São Fidélis e Campos dos Goytacazes (Rio de Janeiro, Brasil), referente à série amostral 2014-2019. Para tanto, foram utilizados os dados das médias mensais. Fonte: Instituto Estadual do Ambiente (2019).

comprometer a vida dos organismos aquáticos. Nota-se também que ambos os municípios apresentam concentrações de oxigênio dissolvido que são compatíveis com a sua classe de enquadramento.

A Figura 3 também apresenta duas tendências fundamentais. A primeira refere-se ao fato de que as concentrações médias mensais de oxigênio dissolvido são mais altas em São Fidélis do que em Campos dos Goytacazes. Apesar de a cidade de São Fidélis dispor de um serviço de saneamento que é muito menos eficiente que o de Campos dos Goytacazes, na medida em que despeja todo o esgoto que coleta nos corpos hídricos (Tabela 1), enquanto Campos dos Goytacazes coleta cerca de $80 \%$ do esgoto que produz e trata $100 \%$ do que coleta (Tabela 2), quando se levam em consideração as diferenças entre os totais populacionais de ambos os municípios, verifica-se que Campos dos Goytacazes ainda assim contribui proporcionalmente com mais esgotos para o rio Paraíba do Sul que São Fidélis ${ }^{2}$ (Tabelas 1 e 2). Outro aspecto importante é que, tanto em São Fidélis quanto em Campos, a população é predominantemente urbana (cerca de 79\% e 90\%, respectivamente, em 2019) e se concentra nas margens do rio (Figura 1), proximidade essa que favorece o seu uso como receptáculo de dejetos.

Os dados em questão mostram que, apesar da maior eficiência do serviço de saneamento de Campos dos Goytacazes, que determina uma concentração menor de bactérias decompositoras nos corpos hídricos - conforme será visto no item referente aos coliformes termotolerantes -, as mais elevadas vazões fluviais do rio Paraíba do Sul identificadas neste município em relação às vazões registradas em São Fidélis (COMITÊ DA BACIA HIDROGRÁFICA DO BAIXO RIO PARAÍBA DO SUL E ITABAPOANA, 2014) promovem ali uma turbulência maior do fluxo fluvial, especialmente

2 O serviço de saneamento em São Fidélis é realizado pela prefeitura municipal do município, e em Campos dos Goytacazes, pela empresa Águas do Paraíba S/A. 
Tabela 1 - Dados populacionais e de saneamento do município de São Fidélis (Rio de Janeiro, Brasil), referente à série amostral $2014-2019$.

\begin{tabular}{|c|c|c|c|c|c|c|c|}
\hline $\begin{array}{l}\text { Ano de } \\
\text { referência }\end{array}$ & $\begin{array}{l}\text { Pop. total do } \\
\text { município }\end{array}$ & $\begin{array}{l}\text { Pop. urbana } \\
\text { do município }\end{array}$ & $\begin{array}{l}\text { Pop. urbana } \\
\text { (\%) }\end{array}$ & $\begin{array}{l}\text { Pop. total } \\
\text { atendida } \\
\text { com esgot. } \\
\text { sanit. }\end{array}$ & $\begin{array}{l}\text { Pop. total } \\
\text { atendida } \\
\text { com esgot. } \\
\text { sanit. (\%) }\end{array}$ & $\begin{array}{l}\text { Vol. de } \\
\text { esgotos } \\
\text { coletado } \\
\text { (1.000 m/ano) }\end{array}$ & $\begin{array}{l}\text { Vol. de } \\
\text { esgotos } \\
\text { tratado } \\
\left(1.000 \mathrm{~m}^{3} / \text { ano }\right)\end{array}$ \\
\hline 2019 & 38.669 & 30.569 & 79,1 & 33.850 & 87,54 & $1.968,22$ & 0 \\
\hline 2018 & 38.626 & 30.535 & 79,1 & 33.850 & 87,64 & $1.968,22$ & 0 \\
\hline 2017 & 37.689 & 29.794 & 79,1 & 33.800 & 89,68 & $1.958,22$ & 0 \\
\hline 2016 & 37.696 & 29.800 & 79,1 & 32.798 & 87,01 & $1.758,21$ & 0 \\
\hline 2015 & 37.703 & 29.805 & 79,1 & 32.798 & 86,99 & $1.758,21$ & 0 \\
\hline 2014 & 37.710 & 29.811 & 79,1 & 29.817 & 79,07 & $1.758,21$ & 0 \\
\hline
\end{tabular}

Fonte: Sistema Nacional de Informações sobre Saneamento (2021) (os dados populacionais disponibilizados pelo SNIS são provenientes do IBGE).

Tabela 2 - Dados populacionais e de saneamento do município de Campos dos Goytacazes (Rio de Janeiro, Brasil), referente à série amostral 2014-2019.

\begin{tabular}{|c|c|c|c|c|c|c|c|}
\hline $\begin{array}{l}\text { Ano de } \\
\text { referência }\end{array}$ & $\begin{array}{l}\text { Pop. total do } \\
\text { município }\end{array}$ & $\begin{array}{l}\text { Pop. urbana } \\
\text { do município }\end{array}$ & $\begin{array}{l}\text { Pop. urbana } \\
\text { (\%) }\end{array}$ & $\begin{array}{l}\text { Pop. total } \\
\text { atendida } \\
\text { com esgot. } \\
\text { sanit. }\end{array}$ & $\begin{array}{l}\text { Pop. total } \\
\text { atendida } \\
\text { com esgot. } \\
\text { sanit. (\%) }\end{array}$ & $\begin{array}{l}\text { Vol. de } \\
\text { esgotos } \\
\text { coletado } \\
\left(1.000 \mathrm{~m}^{3} / \mathrm{ano}\right)\end{array}$ & $\begin{array}{l}\text { Vol. de } \\
\text { esgotos } \\
\text { tratado } \\
\left.\text { ( } 1.000 \mathrm{~m}^{3} / \mathrm{ano}\right)\end{array}$ \\
\hline 2019 & 507.548 & 458.289 & 90,3 & 421.627 & 83,07 & $12.745,00$ & $12.745,00$ \\
\hline 2018 & 503.424 & 454.566 & 90,3 & 409.125 & 81,27 & $11.899,34$ & $11.899,34$ \\
\hline 2017 & 490.288 & 442.705 & 90,3 & 398.448 & 81,27 & $11.557,56$ & $11.557,56$ \\
\hline 2016 & 487.186 & 439.904 & 90,3 & 395.914 & 81,27 & $10.864,74$ & $10.864,74$ \\
\hline 2015 & 483.970 & 437.000 & 90,3 & 369.972 & 76,45 & $10.885,96$ & $10.885,96$ \\
\hline 2014 & 480.648 & 434.000 & 90,3 & 349.571 & 72,73 & $14.583,20$ & $14.583,20$ \\
\hline
\end{tabular}

Fonte: Sistema Nacional de Informações sobre Saneamento (2021) (os dados populacionais disponibilizados pelo SNIS são provenientes do IBGE).

em sentido vertical na lâmina d'água, colocando em suspensão tanto a matéria orgânica sólida quanto as bactérias que se encontram depositadas no leito fluvial. Essa movimentação aumenta a eficiência dos processos de decomposição, elevando, assim, o consumo do oxigênio dissolvido do rio em Campos dos Goytacazes.

A segunda tendência identificada na Figura 3 refere-se ao fato de que, tanto em São Fidélis quanto em Campos dos Goytacazes, as concentrações de oxigênio dissolvido são mais elevadas durante o período de estiagem (entre junho e setembro) do que durante o período úmido (entre novembro e março). Esse resultado indica a ocorrência de duas situações distintas e complementares. Uma delas relaciona-se ao maior carreamento de esgotos para o rio via escoamento superficial, tendo como origem as áreas que não são atendidas por serviços de saneamento em ambos os municípios, em função da maior concentração de chuvas durante o período úmido. A outra situação diz respeito ao fato de que, nessa época do ano, há aumento das vazões fluviais, também em resposta ao aumento das chuvas, cujas consequências já foram apontadas no parágrafo anterior. Todos esses fatores atuam de tal modo a aumentar o consumo do oxigênio dissolvido durante o período úmido e a reduzi-lo durante o período seco.

De acordo com a Figura 4, constata-se também que as variações do comportamento do oxigênio dissolvido entre os anos do monitoramento analisados neste estudo foram 


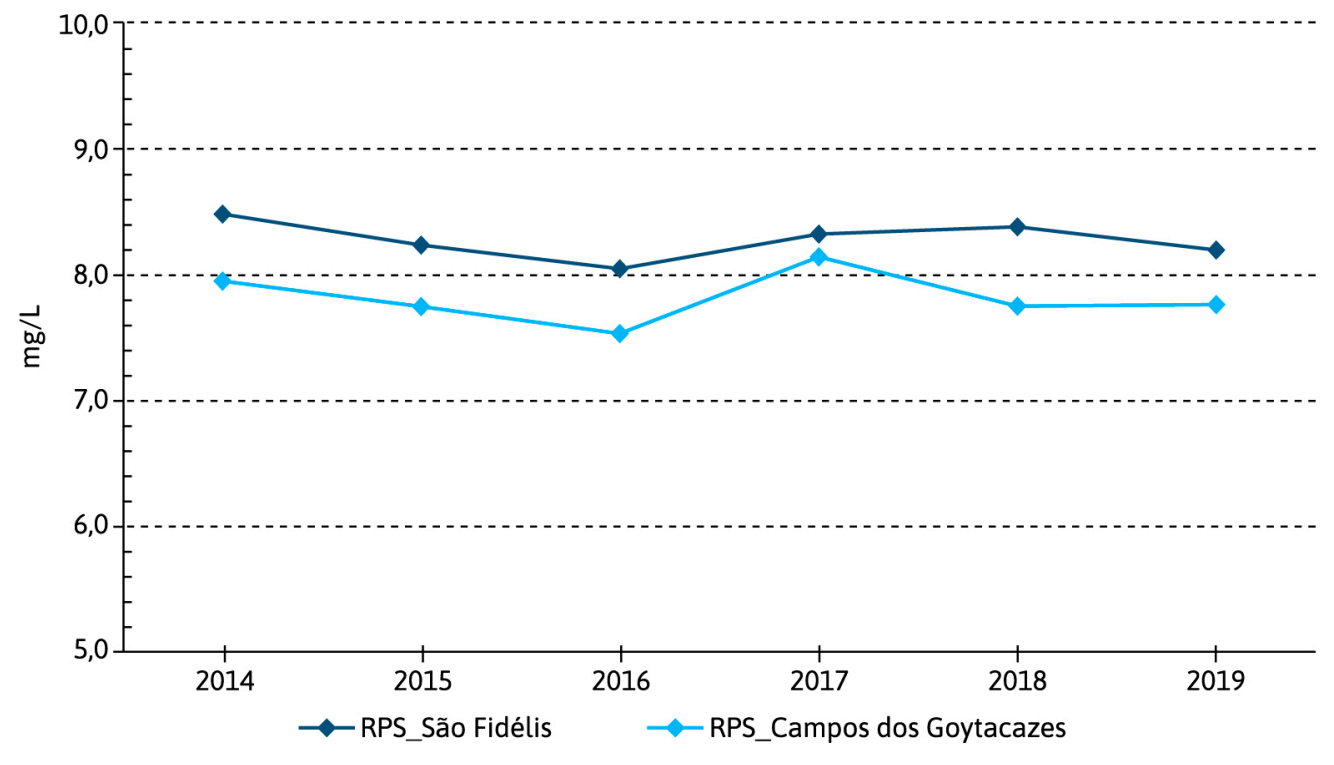

Figura 4 - Comportamento das médias anuais de oxigênio dissolvido (em $\mathrm{mg} / \mathrm{L}$ ) nos pontos amostrais do rio Paraíba do Sul (RPS), localizados nos municípios de São Fidélis e Campos dos Goytacazes (Rio de Janeiro, Brasil), referente à série amostral 2014-2019. Para tanto, foram utilizados os dados das médias anuais.

Fonte: Instituto Estadual do Ambiente (2019).

muito pequenas. Contudo, percebe-se um ligeiro decréscimo entre os anos de 2015 e 2016, o qual possivelmente reflete o declínio significativo das vazões fluviais identificado na área, que é objeto deste estudo, durante a seca que afetou a região Sudeste brasileira entre os anos de 2014 e 2016. Considerando que o declínio em questão não foi acompanhado por um decréscimo na produção e, consequentemente, no despejo dos esgotos (tratados ou não) no rio Paraíba do Sul (Tabelas 1 e 2), nessa circunstância houve uma redução da aeração das águas e, logo, do oxigênio dissolvido ali disponível, em um contexto em que, se não aumentou, a quantidade de matéria orgânica passível de ser decomposta pelas bactérias ao menos permaneceu semelhante à dos anos anteriores, causando a queda das concentrações dessa substância ao longo desse período. O declínio das vazões e suas respectivas consequências ambientais encontram-se amplamente discutidos nos trabalhos do CBH BPSI (COMITÊ DA BACIA HIDROGRÁFICA DO BAIXO RIO PARAÍBA DO SUL E ITABAPOANA, 2014) e de Leite (2015 e 2017).

\section{2 - Coliformes termotolerantes}

De acordo com Von Sperling (2014), os microrganismos presentes nos esgotos e em cursos d'água realizam diversas funções fundamentais, especialmente no que se refere à transformação da matéria orgânica por meio dos ciclos biogeoquímicos e aos processos de autodepuração da água, conforme mencionado na seção anterior. No que diz respeito à qualidade da água, verifica-se que alguns tipos de microrganismos, como bactérias, vírus, protozoários e helmintos, podem ser transmissores de doenças tanto para humanos quanto para animais.

Organismos dessa natureza, quando estão presentes nos esgotos, têm uma gênese predominantemente humana, ainda que, em menor proporção, também sejam oriundos de dejetos animais, revelando, deste modo, tanto os padrões de qualidade de saúde da 
população quanto as condições de saneamento a que ela está submetida. Assim sendo, a quantidade de patógenos presentes no esgoto de determinada localidade é variável e relaciona-se aos seguintes fatores: (a) condições socioeconômicas da população; (b) condições sanitárias; (c) região geográfica; (d) presença de indústrias agroalimentares; e (e) tipo de tratamento a que o esgoto e o lodo foram submetidos (no caso de esgotos tratados) (VON SPERLING, op. cit.). Dentro dessa perspectiva, as localidades que não dispõem de uma infraestrutura adequada de saneamento, ou seja, de serviços que promovam o tratamento e a distribuição de água tratada, assim como a coleta e o tratamento dos esgotos de forma ampla e irrestrita, são aquelas que, por uma questão de (falta de) saúde, tendem a contribuir mais com a contaminação dos efluentes que são lançados nos corpos d'água.

Pelo fato de as concentrações dos agentes patogênicos serem muito baixas nos corpos hídricos, a sua detecção em uma amostra de água é uma tarefa bastante difícil. Para contornar esse problema, passou-se a utilizar os organismos indicadores de contaminação fecal, que, apesar de serem predominantemente não patogênicos, dão uma boa noção do quanto um corpo d'água se encontra contaminado por fezes humanas ou de animais e, consequentemente, da sua potencialidade em transmitir doenças. Os organismos mais frequentemente utilizados para esse propósito são as bactérias do grupo coliforme, pois se encontram disponíveis em grande quantidade nas fezes humanas e também porque apresentam resistência ligeiramente superior à maioria das bactérias patogênicas intestinais nos ambientes aquáticos (VON SPERLING, op. cit.).

Entre os indicadores de contaminação fecal mais frequentemente utilizados estão os coliformes fecais, que correspondem a um grupo de bactérias cuja origem é o trato intestinal humano e de outros animais. O teste para a sua detecção é feito sob altas temperaturas, tendo como objetivo a eliminação de bactérias não fecais. Contudo, mesmo nessas condições, verifica-se que uma pequena quantidade delas ainda permanece, impedindo que se tenha a total garantia de que a contaminação ali evidenciada é de fato fecal. Por esse motivo, passou-se a denominar os coliformes fecais de coliformes termotolerantes (VON SPERLING, op. cit.).

Quanto às concentrações de coliformes termotolerantes consideradas aceitáveis para as águas doces destinadas ao abastecimento humano pela Resolução CONAMA 357/2005, constata-se que, para a classe 1, não pode ser ultrapassado o limite de 200 coliformes termotolerantes por 100 mililitros, em $80 \%$ ou mais de pelo menos 6 amostras, coletadas durante um período de um ano, com frequência bimestral. Em relação às classes 2 e 3, os limites que não devem ser excedidos, sob as mesmas condições, são de 1.000 e 4.000 coliformes termotolerantes, respectivamente.

No que diz respeito ao comportamento dos dados de coliformes termotolerantes analisados neste estudo, observa-se que as concentrações desses organismos foram muito mais elevadas no rio Paraíba do Sul em São Fidélis do que em Campos dos Goytacazes (Figura 5). Enquanto em São Fidélis as concentrações de coliformes termotolerantes apresentaram valores médios mensais completamente fora do padrão de enquadramento do rio definido para aquela localidade (classe 2), as concentrações desses organismos em Campos dos Goytacazes estiveram bastante abaixo do padrão previsto para aquele trecho do rio (classe 3) durante o mesmo intervalo de tempo, com exceção apenas do mês de dezembro. 


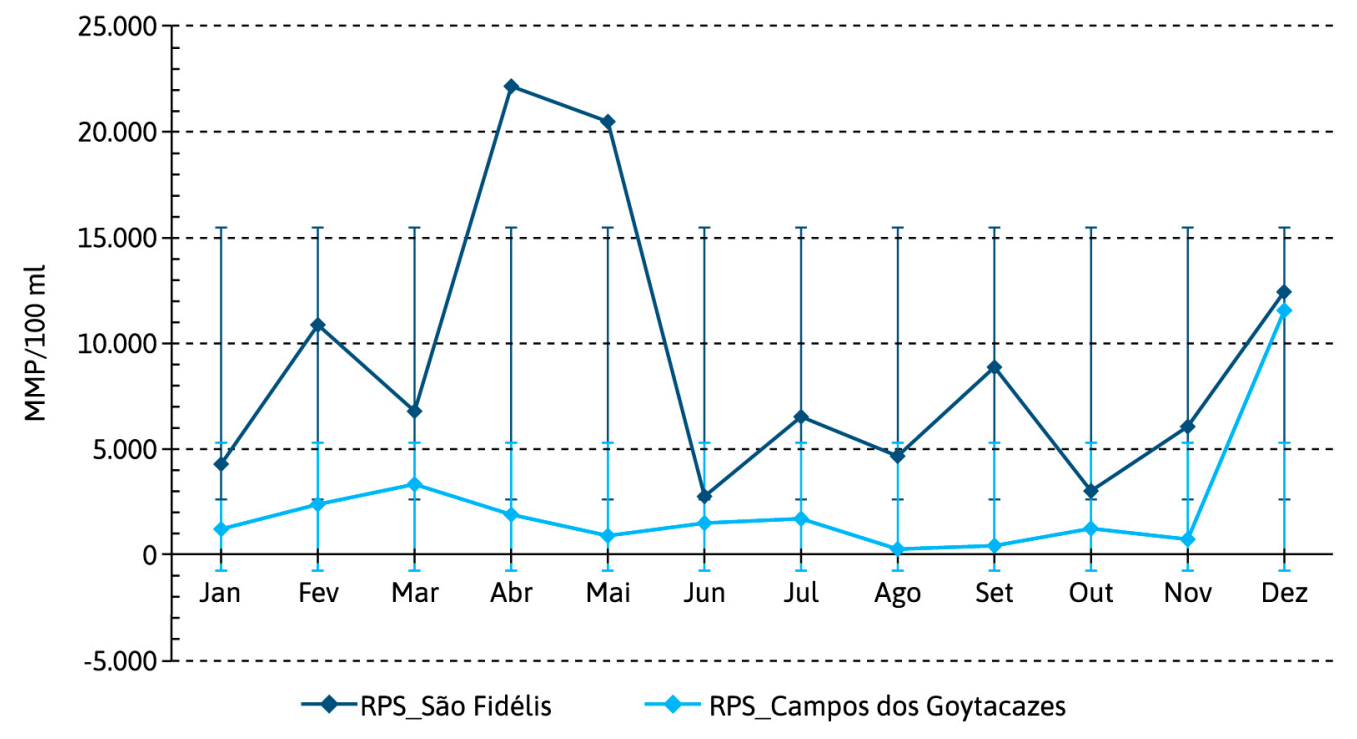

Figura 5 - Comportamento sazonal dos coliformes termotolerantes (em MMP/100 mL) nos pontos amostrais do rio Paraíba do Sul (RPS), localizados nos municípios de São Fidélis e Campos dos Goytacazes (Rio de Janeiro, Brasil), referente à série amostral 2014-2019. Para tanto, foram utilizados os dados das médias mensais com barras de desvio padrão.

Fonte: Instituto Estadual do Ambiente (2019).

Esse resultado é explicado pelas diferenças entre procedimentos utilizados pelos serviços de saneamento de cada um dos municípios considerados neste estudo, no que se refere à coleta e ao despejo dos esgotos coletados, os quais já foram aqui apontados. Sendo assim, apesar de a população de São Fidélis ter sido majoritariamente atendida por serviços de coleta de esgoto (entre 79\% e 87\% dos habitantes entre 2014 e 2019), todo o esgoto ali recolhido foi despejado nos corpos hídricos, no rio Paraíba do Sul em especial, sem ter recebido qualquer tipo de tratamento (Tabela 1).

Já em Campos dos Goytacazes, apesar de a população ser muito maior, todo o esgoto coletado recebeu tratamento antes de ter sido lançado nos corpos hídricos (Tabela 2). Ainda que a quantidade de habitantes ali residentes que não é atendida por serviços de saneamento seja maior que a população total de São Fidélis (cerca de 86 mil habitantes em 2019), o efeito de diluição das concentrações de coliformes nas águas causado pela emissão dos esgotos tratados no rio, ou seja, após a remoção desses organismos, é evidente. Além disso, o volume de água que converge para esse ponto da bacia hidrográfica proveniente das áreas posicionadas a montante, incluindo as contribuições da rede tributária do rio Paraíba do Sul, também é maior que aquele que chega até São Fidélis.

No que se refere às tendências sazonais, apresentadas no gráfico da Figura 6, ainda que à primeira vista não sejam tão claras, elas existem. Ao contrário do que se evidenciou em relação às concentrações de oxigênio dissolvido, cujas médias se mostraram bastante representativas do conjunto dos dados, as concentrações de coliformes termotolerantes apresentaram uma grande amplitude de variação entre os valores máximos e os mínimos dentro da série amostral, determinado, assim, um valor de média que, neste caso, não constitui o parâmetro estatístico que melhor lhe representa. Esse comportamento foi mais evidente em relação aos dados de São Fidélis, em especial nos meses de abril e maio. Por esse motivo, a identificação imediata do comportamento sazonal foi prejudicada, e as 


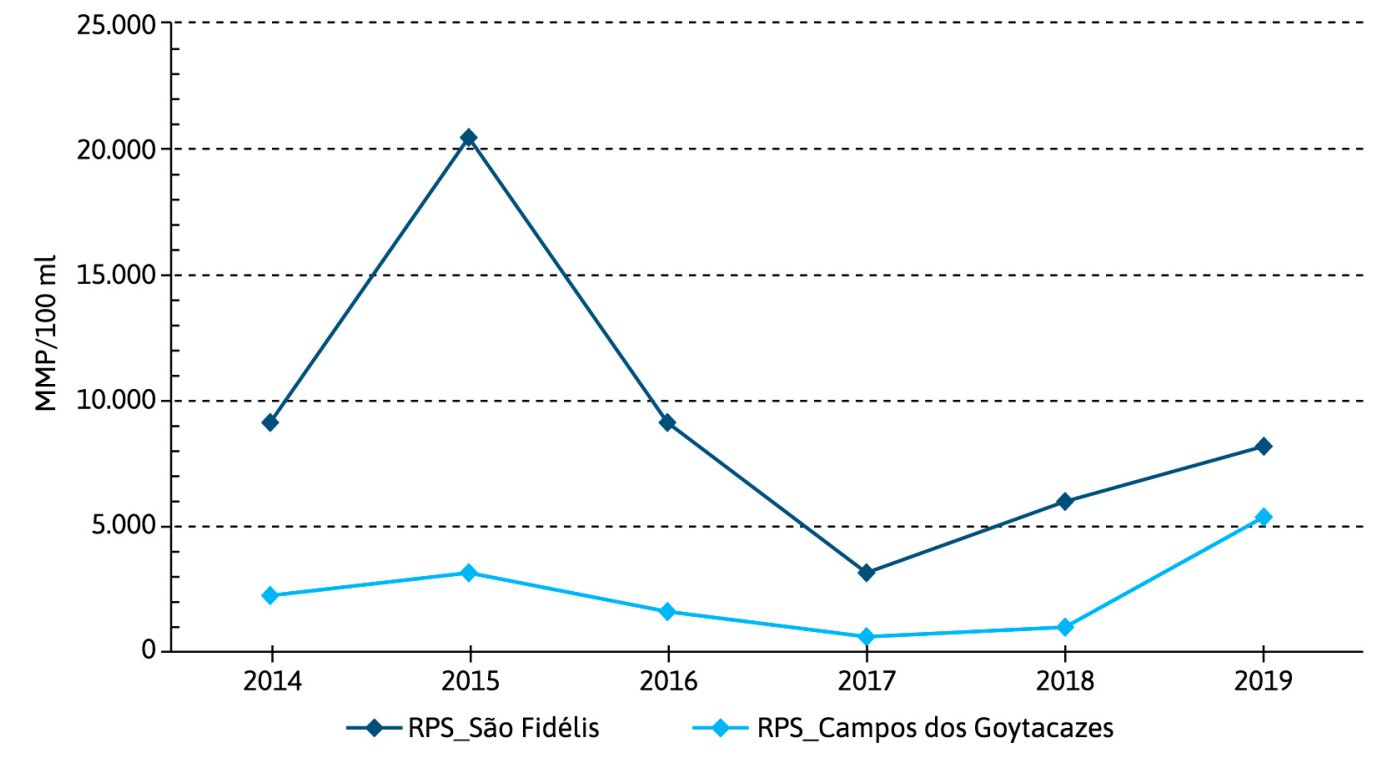

Figura 6 - Comportamento das médias anuais de coliformes termotolerantes (em MMP/100 mL) nos pontos amostrais do rio Paraíba do Sul (RPS), localizados nos municípios de São Fidélis e Campos dos Goytacazes (Rio de Janeiro, Brasil), referente à série amostral 2014-2019. Para tanto, foram utilizados os dados das médias anuais. Fonte: Instituto Estadual do Ambiente (2019).

barras de desvio padrão foram inseridas. Seja como for, observa-se que, em ambos os municípios monitorados, as concentrações de coliformes termotolerantes são mais altas durante o período úmido e mais baixas durante o período seco. Esse comportamento reflete tanto a influência do carreamento das áreas urbanizadas do entorno via escoamento superficial quanto o revolvimento do leito fluvial promovido pelo aumento das vazões durante a época chuvosa.

Quanto às variações das médias anuais, percebe-se que, em ambos os municípios monitorados, há variações anuais significativas, as quais também são explicadas pelas grandes amplitudes de variação que existem entre os dados das concentrações máximas e mínimas de coliformes termotolerantes do conjunto amostral, conforme discutido no parágrafo anterior. Esse comportamento tem relação com o fato de que a quantidade de coliformes que é disponibilizada para os corpos hídricos é fortemente influenciada por fatores locais, que estão diretamente relacionados com as atividades desenvolvidas pelos seres que produzem os coliformes. Como esses fatores são dinâmicos, eles podem alterar significativamente as concentrações desses organismos pontualmente, ou seja, durante um evento de amostragem da água, sem que haja necessariamente um efeito cumulativo de sua influência entre a coleta realizada nesse momento e a seguinte.

\section{Considerações finais}

No município de São Fidélis, que apresenta um total populacional de 38.670 habitantes (em 2019), sendo 79\% urbano e concentrado nas margens do rio Paraíba do Sul, cerca de $87 \%$ dos residentes são atendidos por serviços de esgotamento sanitário, mas todo o esgoto ali coletado é lançado nos corpos hídricos sem que tenha passado por nenhum tipo de tratamento. Tal procedimento, apesar de ainda não ter comprometido os níveis 
de oxigenação da água, que garantem a manutenção das condições de existência dos seres aquáticos, comprometeu significativamente os seus padrões de salubridade no que se refere aos usos a serem feitos por seres humanos, tendo em vista que as concentrações de coliformes termotolerantes registradas nessa localidade se encontram muito acima dos padrões estabelecidos para corpos hídricos de classe 2, conforme prescrito na Resolução CONAMA 357/2005. Esse distúrbio se intensifica durante o período úmido por causa da ocorrência de chuvas concentradas, na medida em que a rede fluvial recebe contribuições mais significativas de esgotos provenientes das áreas desprovidas de infraestrutura, os quais são carreados pelo escoamento superficial, assim como também do lodo concentrado no leito do rio, que é remobilizado em função do aumento das vazões nessa época do ano. Cabe aqui lembrar que as taxas de transporte por meio do escoamento superficial são intensificadas pela declividade das encostas (já intensamente desmatadas) e pela urbanização que impermeabiliza as superfícies.

Em Campos dos Goytacazes, que apresenta um total populacional de 507.548 habitantes (em 2019), sendo 90\% urbano e também concentrado nas margens do rio Paraíba do Sul, cerca de $83 \%$ dos residentes são atendidos por serviços de esgotamento sanitário. Contudo, ao contrário do ocorre em São Fidélis, todo o esgoto coletado no município é lançado nos corpos hídricos após ter passado por tratamento. Tal procedimento foi responsável por manter as concentrações de oxigênio dissolvido sempre dentro dos padrões e as de coliformes termotolerantes majoritariamente dentro dos padrões. Verifica-se, neste caso, que, apesar de a população de Campos dos Goytacazes ser muito maior que a de São Fidélis, e de o nível de exigência associado ao padrão de enquadramento do rio nessa localidade, que é de classe 3, ser mais baixo, há fatores ambientais que contribuem para a atenuação das concentrações de coliformes termotolerantes ali identificadas, além do próprio efeito de diluição proporcionado pelo despejo do esgoto após ter passado por tratamento. Um deles diz respeito à influência da topografia plana da área que margeia o rio Paraíba do Sul em Campos dos Goytacazes, o que reduz significativamente as taxas de produção do escoamento superficial em comparação com São Fidélis, especialmente no período de estiagem, quando os totais de chuva são ínfimos, apesar da maior urbanização do município. O outro relaciona-se às mais altas vazões do rio nesse local em relação à São Fidélis, especialmente no período úmido, que é expressão do maior volume de água disponível nesse ponto da bacia hidrográfica para diluir a concentração desses organismos.

Assim sendo, é fundamental que se dê destaque aos papéis exercidos tanto pelos serviços de saneamento quanto pelas vazões fluviais. No caso dos serviços de saneamento, os dados analisados neste estudo deixam claro que, guardadas as diferenças das características do ambiente que influenciam o comportamento dos parâmetros analisados, são nítidos os contrastes identificados na qualidade da água de um mesmo rio que corta dois municípios distintos, sendo que um descarta os esgotos após tratamento e o outro descarta sem tratá-los. Os serviços de saneamento são fundamentais, porque eles determinam o bemestar e a qualidade de vida da população, principalmente no que diz respeito à saúde. Infelizmente, o atendimento amplo e irrestrito da população brasileira por serviços de saneamento ainda não é uma realidade. De acordo com o SNIS (SISTEMA NACIONAL DE INFORMAÇÕES SOBRE SANEAMENTO, 2020), no ano de 2019, apenas 49,1\% dos esgotos gerados no Brasil receberam tratamento. Trata-se de uma proporção extremamente baixa considerando o total de 211,8 milhões de habitantes que o país possui. No que se refere à região Sudeste, nesse mesmo ano, a proporção de esgotos tratados foi de 55,5\%, 
sendo, portanto, apenas um pouco mais elevada que a média nacional, apesar de ser a região com maior densidade populacional do país.

É importante também enfatizar a importância de os serviços de saneamento serem oferecidos por empresas públicas. A privatização desse setor da gestão dos recursos hídricos, além de provocar o aumento de tarifas e desabastecimento, não garante o acesso de todos os habitantes à água. Outros problemas também notificados após a privatização referem-se ao não cumprimento de promessas feitas inicialmente e à falta de transparência no funcionamento das empresas. Por esses motivos, diversas cidades do mundo estão voltando atrás e reestatizando os seus serviços de saneamento. De acordo com a BBC (BBC NEWS BRASIL, 2017), da virada do milênio até então, foram registrados 267 casos de reestatização no mundo, os quais incluíram cidades como Berlim, Paris, Budapeste, Bamako, Buenos Aires, Maputo e La Paz.

Em relação às vazões fluviais, constata-se que, assim como os serviços de saneamento, elas têm um papel fundamental na manutenção dos padrões de qualidade da água. Contudo, o rio Paraíba do Sul vem passando por um processo de declínio das vazões de longo prazo, o qual tem sido especialmente prejudicial na região do médio/baixo curso (COMITÊ DA BACIA HIDROGRÁFICA DO BAIXO RIO PARAÍBA DO SUL E ITABAPOANA, 2014; LEITE, 2017, 2019) e tem relação com o aumento das captações de água dentro da bacia como um todo, em particular pelas hidrelétricas e pela transposição existente no médio curso, que desvia cerca $70 \%$ da água para atender ao setor elétrico e ao abastecimento da Região Metropolitana do Rio de Janeiro. Contudo, há também fatores agravantes desse processo na região que foi objeto desta análise. Enquanto em São Fidélis se evidencia um intenso assoreamento da calha fluvial, em Campos dos Goytacazes o amplo processo de drenagem das áreas úmidas que margeavam o Paraíba causou o rebaixamento do nível freático local que é responsável por manter a sua perenidade. Caso o processo de declínio das vazões tenha continuidade, há possibilidade de que tanto a escassez hídrica, que já se evidencia localmente, tenda a se intensificar, tornando as históricas disputas pela água cada vez mais acentuadas, quanto os serviços de saneamento sejam prejudicados, na medida em que o tratamento da água e dos esgotos se tornará cada vez mais difícil e caro.

\section{Referências bibliográficas}

BBC NEWS BRASIL. Enquanto Rio privatiza, por que Paris, Berlim e outras 265 cidades reestatizaram saneamento? BBC News Brasil, Rio de Janeiro, 2017. Disponível em: <https://www.bbc.com/portuguese/ brasil-40379053>. Acesso em: 14 mar. 2021.

BRASIL. Ministério do Meio Ambiente. Conselho Nacional do Meio Ambiente - CONAMA. Resolução $n^{\circ} 357$, de 17 de março de 2005. Dispõe sobre a classificação dos corpos de água e diretrizes ambientais para o seu enquadramento, bem como estabelece as condições e padrões de lançamento de efluentes, e dá outras providências, Diário Oficial da República Federativa do Brasil, Brasília, DF, 2005. Disponível em: <http://www2.mma.gov.br/port/conama/legiabre.cfm?codlegi=459>. Acesso em: 06 mar. 2020.

COMITÊ DA BACIA HIDROGRÁFICA DO BAIXO RIO PARAÍBA DO SUL E ITABAPOANA - CBH BPSI. Nota Técnica CBH BPSI - Decisão do Comitê do Baixo Paraíba do Sul e Itabapoana acerca da redução de vazões de chegada na transposição de Santa Cecília. Campos dos Goytacazes: $\mathrm{CBH}$ BPSI e AGEVAP, 2014. Disponível em: <http://cbhbaixoparaiba.org.br/conteudo/Bol_Tecnico_CBHBPSI_v1-n1-jun2014.pdf>. Acesso em: 05 set. 2016.

COMITÊ DE INTEGRAÇÃO DA BACIA HIDROGRÁFICA DO RIO PARAÍBA DO SUL - CEIVAP. Enquadramento vigente dos rios federais e estaduais na Bacia do Rio Paraíba do Sul. Resende: CEIVAP, 2020. Disponível em: <https://www.ceivap.org.br/images/Mapa_enquadramento.png >. Acesso em 15 jun. 2021. 
COMPANHIA AMBIENTAL DO ESTADO DE SÃO PAUlO - CETESB. Mortandade de peixes: matéria orgânica e nutrientes. São Paulo: CETESB, 2021. Disponível em: <https://cetesb.sp.gov.br/ mortandade-peixes/alteracoes-fisicas-e-quimicas/materia-organica-e-nutrientes/\#: :text=A\%20 matéria\%20orgânica\%20sofre\%20um,do\%20oxigênio\%20presente\%20no\%20meio.\&text=Com\%20 a\%20decomposição\%20da\%20matéria,superiores\%20para\%20o\%20seu\%20crescimento >. Acesso em: 10 mar. 2021.

ESTEVES, F. A.; FURTADO, A. L. S. Oxigênio dissolvido. In: ESTEVES, F. A. (Coord.). Fundamentos de Limnologia. 3. ed. Rio de Janeiro: Interciência, 2011. p. 167-191.

FRANCHI, J. G.; SÍGOLO, J. B.; MOTTA, J. F. M. Diagnóstico das turfas no Brasil: histórico da utilização, classificação, geologia e dados econômicos. Revista Brasileira de Geociencias, São Paulo, v. 36, n. 1, p. 179-190, 2006.

GOUDIE, A. S.; VILES, H. A. Subsidence in the Anthropocene. In: GOUDIE, A. S.; VILES, H. A. (Ed.). Geomorphology in the Anthropocene. 1st ed. Cambridge: Cambridge University Press, 2016. p. 57-70.

INSTITUTO ESTADUAL DO AMBIENTE - INEA. Qualidade das Águas por Região Hidrográfica (RHs). Rio de Janeiro: INEA, 2019. Disponível em: <http://www.inea.rj.gov.br/ar-agua-e-solo/qualidade-dasaguas-por-regiao-hidrografica-rhs/>. Acesso em: 13 jan. 2020.

LAMEGO, A. R. O homem e o brejo. 1. ed. (fac-sim). Rio de Janeiro: Instituto Brasileiro de Geografia e Estatística (IBGE), 2007. 204 p.

LEITE, A. F. Discharge decline, hydric availability, risks and vulnerability in the low Paraíba do Sul River, Rio de Janeiro, Brazil. In: INTERNATIONAL GEOGRAPHICAL UNION REGIONAL CONFERENCE - GEOGRAPHY, CULTURE AND SOCIETY FOR OUR FUTURE EARTH, 15., 2015, Moscou. Anais... Moscou, 2015.

LEITE, A. F. Gestão dos recursos hídricos e desastres relacionados à água na baixada Campista. In: ENCONTRO NACIONAL DOS PROGRAMAS DE PÓS-GRADUAÇÃO EM GEOGRAFIA (ENANPEGE) - GEOGRAFIA, CIÊNCIA E POLÍTICA: DO PENSAMENTO À AÇÃO, DA AÇÃO AO PENSAMENTO, 12., 2017, Porto Alegre. Anais... Porto Alegre, 2017.

LEITE, A. F. Estruturas hidráulicas, gestão dos recursos hídricos e desastres relacionados à água na região do baixo curso do rio Paraíba do Sul (estado do Rio de Janeiro): uma análise fundamentada no desastre deflagrado pela inundação de 2007. Ambientes: Revista de Geografia e Ecologia Política, Francisco Beltrão, v. 1, n. 1, p. 146-190, 2019.

MENDONÇA, J. C. Inundações na baixada Campista. In: TOTTI, M. E. F.; SOFFIATI, A. (Org.). Gestão de águas no baixo rio Paraíba do Sul: região hidrográfica IX do estado do Rio de Janeiro. 1. ed. Campos dos Goytacazes: Essentia, 2014. p. 91-127.

NICKNIG, W. A. Evolução da rede de monitoramentos hidrométricos da Região Norte Fluminense. 2016. Trabalho de Conclusão de Curso (Bacharelado em Geografia)-Universidade Federal Fluminense, 2016.

SISTEMA NACIONAL DE INFORMAÇÕES SOBRE SANEAMENTO - SNIS. Diagnóstico dos serviços de águas e esgotos - 2019. Brasília: Ministério do Desenvolvimento Regional, 2020. Disponível em: $<$ http://www.snis.gov.br/diagnosticos>. Acesso em: 14. mar. 2021.

SISTEMA NACIONAL DE INFORMAÇÕES SOBRE SANEAMENTO - SNIS. SNIS - Série Histórica. Brasília: Ministério do Desenvolvimento Regional, 2021. Disponível em: <http://app4.mdr.gov.br/ serieHistorica/\#>. Acesso em: 11 mar. 2021.

SUMMERFIELD, M. A. Fluvial processes. In: SUMMERFIELD, M. A. (Ed.). Global geomorphology. 1st ed. Essex: Pearson Education Limited - Prentice Hall, 1991. p. 191-204.

VON SPERLING, M. Estudos e modelagem da qualidade da água de rios. 2. ed. Belo Horizonte: UFMG, 2014. 588 p.

VON SPERLING, M. Introdução à qualidade das águas e ao tratamento de esgotos. 4. ed. Belo Horizonte: UFMG, 2018. 470 p. 
SOBRE OS AUTORES

Bruna Almeida Ribeiro (RIBEIRO, B. A.). Mestranda do Programa de Pós-Graduação em Geografia da Universidade Federal Fluminense, em Campos dos Goytacazes.

Adriana Filgueira Leite (LEITE, A. F.). Professora do Departamento de Geografia e do Programa de Pós-Graduação em Geografia da Universidade Federal Fluminense, em Campos dos Goytacazes. Coordenadora do Laboratório de Geomorfologia, Hidrologia e Recursos Hídricos (GEOHIDRO). 
Seção Final 


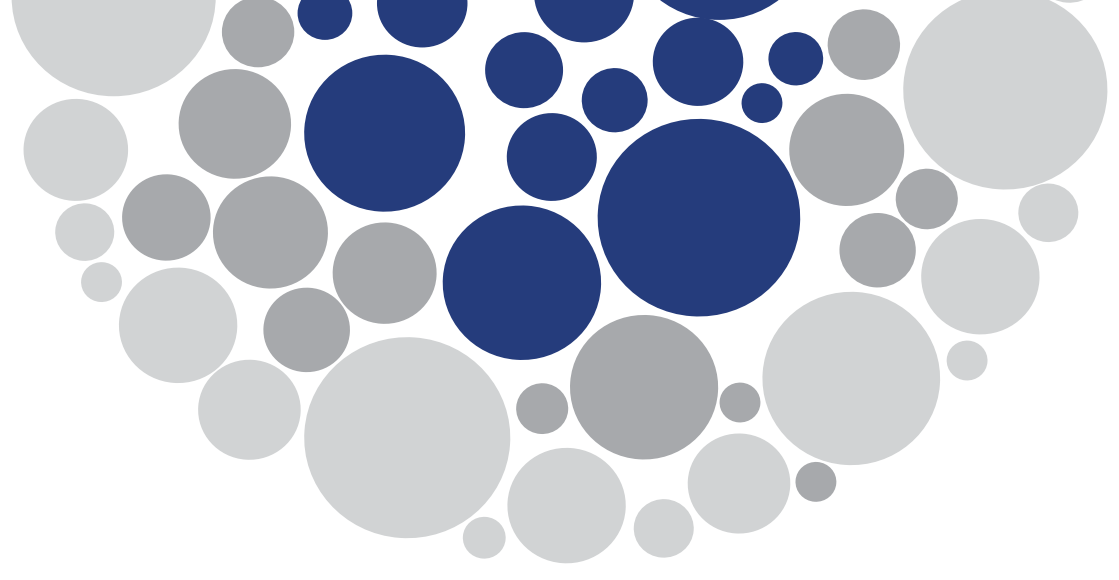

\title{
Análise das dissertações defendidas no Programa de Pós-Graduação em Geografia da UFF/Campos: contribuição para a autoavaliação do programa
}

\author{
Marcelo Werner da Silva ${ }^{a}$ \\ a Coordenador do Programa de Pós-Graduação em Geografia da UFF/CAMPOS. E-mail: marcelows@id.uff.br
}

\section{Introdução}

Este texto é uma contribuição para a avaliação do Programa de Pós-Graduação em Geografia (PPG) da Universidade Federal Fluminense, em Campos dos Goytacazes (UFF/Campos), pois, atualmente, os órgãos reguladores da pós-graduação exigem que se faça uma autoavaliação. Para tanto, vamos explicitar esses critérios autoavaliativos e discorrer sobre algumas características das dissertações desenvolvidas no PPG desde seu início, que se deu em 2014.

\section{A autoavaliação da pós-graduação brasileira}

Para a Coordenação de Aperfeiçoamento de Pessoal de Nível Superior (CAPES), a autoavaliação é 
formativo, de aprendizagem. Uma vez que é planejada, conduzida, implementada e analisada por pessoas elas próprias formuladoras e agentes das ações a serem avaliadas, a autoavaliação possibilita uma reflexão sobre contexto e políticas adotadas, além da sistematização dos dados que levam à tomada de decisão (COORDENAÇÃO DE APERFEIÇOAMENTO DE PESSOAL DE NÍVEL SUPERIOR, 2019, p. 7).

Portanto, trata-se de um processo preparado e gerido pela própria comunidade acadêmica com "a titularidade de avaliação" (COORDENAÇÃO DE APERFEIÇOAMENTO DE PESSOAL DE NÍVEL SUPERIOR, 2019, p. 7) que envolve no processo avaliativo "a participação de distintos atores da academia ou externos a ela (docentes, discentes, egressos, técnicos e outros), nos níveis hierárquicos diversos, dos estratégicos aos mais operacionais" (ibidem). Ainda segundo a CAPES, do trabalho participativo resultam melhores produtos no que se refere à autoavaliação.

O objetivo da CAPES com a autoavaliação é realizar o acompanhamento da forma como cada programa de pós-graduação está conduzindo sua autoavaliação: "Desta maneira, cada programa poderá propor um delineamento de autoavaliação apto a captar aspectos pertinentes a sua missão e seus objetivos, incluindo aqueles relativos à sua inserção no contexto social/internacional e a suas escolhas científicas específicas" (COORDENAÇÃO DE APERFEIÇOAMENTO DE PESSOAL DE NÍVEL SUPERIOR, 2019, p. 9).

No caso específico da área de Geografia, a que o Programa de Pós-Graduação em Geografia da UFF/CAMPOS (PPG) está vinculado, a ficha de avaliação, em seu item 1.4, consigna que serão avaliados "Os processos, procedimentos e resultados da autoavaliação do programa, com foco na formação discente e produção intelectual" (COORDENAÇÃO DE APERFEIÇOAMENTO DE PESSOAL DE NÍVEL SUPERIOR, 2020).

Deste modo, neste texto, vamos dar ênfase na produção intelectual do PPG, apresentando as dissertações produzidas. No entanto, para um melhor conhecimento do Programa, faremos, inicialmente, um pequeno histórico de sua criação.

\section{Histórico e Caracterização do Programa de Pós-Graduação em Geografia da UFF/Campos (PPG)}

O curso de mestrado em Geografia na UFF/Campos foi criado em 2013, apenas quatro anos após a criação do curso de graduação em Geografia, ocorrido em 2009, dentro do Programa de Apoio a Planos de Reestruturação e Expansão das Universidades Federais (REUNI).

O curso foi estruturado em uma área de concentração chamada "Análise Regional e Ambiental", a qual, por sua vez, é dividida em duas linhas de pesquisa: "Análise Regional, Dinâmicas Territoriais e Escalas" e "Sistemas Naturais, Geotecnologias e Demografia". Na proposta do curso, estão consignados os objetivos da área de concentração:

A definição de região parte do princípio da diferenciação de áreas. Por outro lado, o discurso da globalização prega a homogeneização dos espaços. É na interseção das questões relacionadas às especificidades espaciais e na globalização que as questões regionais tomaram novo fôlego nestas primeiras décadas do século XXI. As diversidades territoriais expressas, tanto pelas desigualdades econômicas, quanto pelas diferenças culturais, ampliaram os interesses dos geógrafos em explicar esses fenômenos que podem ser lidos a partir das relações entre fenômenos locais e globais que produzem, 
ao mesmo tempo territórios-zona onde prevalece a lógica política, territórios-rede conformados pela lógica econômica e os aglomerados de exclusão sob a égide da lógica social. Tratam-se, portanto dos espaços onde se reconhecem as articulações dos múltiplos agentes em diferentes escalas de ação. $\mathrm{Na}$ análise regional considera-se os aspectos ambientais em diferentes olhares: sejam nos estudos da evolução, dinâmica e processos dos diferentes componentes dos sistemas naturais a partir de diagnósticos e monitoramentos, ou numa perspectiva ampla, reconhecendo a análise ambiental como a integração de fenômenos sociais, políticos, econômicos, culturais e a natureza, em um recorte espacial específico. As relações inter-escalares dos sujeitos; das agências; das empresas e dos Estados-Nação, redefinem as regiões frente aos circuitos da globalização (UNIVERSIDADE FEDERAL FLUMINENSE, 2021).

\section{A linha de pesquisa de "Análise Regional, Dinâmicas Territoriais e Escalas",}

Fundamenta-se na execução de estudos regionais voltados a discussão ou elaboração de aspectos teóricos, metodológicos e epistemológicos em geografia. Essa linha de pesquisa propõe estudos sobre as dinâmicas territoriais, processos espaciais, instrumentos e políticas voltados à análise regional em suas diferentes escalas (do local ao global). Aborda as estruturas produtivas, os fluxos econômicos, as estratégias de gestão e de governança, os efeitos da globalização, da reestruturação produtiva, dos aspectos culturais, definidores de identidades regionais; além das interfaces entre as dinâmicas territoriais e as questões sociais e ambientais (UNIVERSIDADE FEDERAL FLUMINENSE, 2021).

Por sua vez, a linha de "Sistemas Naturais, Geotecnologias e Demografia" está ligada aos três eixos temáticos que estão identificados em seu nome, articulados da maneira exposta a seguir:

As geotecnologias envolvem a criação de cenários, modelos e análises espaço-temporais de uso e ocupação das terras aplicando diferentes metodologias na adoção das Geotecnologias nas diferentes categorias de análise da Geografia. A demografia aborda estudos sobre a distribuição da população humana no espaço assim como sua estrutura, envolvendo estudos sobre os efeitos territoriais de políticas populacionais; sobre problemas relacionados ao trinômio população, desenvolvimento e ambiente; e a elaboração de análises e diagnósticos demográficos em várias escalas, envolvendo projeções de população, estimativas de demandas sociais e construção de indicadores sociais. Os Sistemas Naturais abordam estudos voltados para o conhecimento e análise ambiental, envolvendo a evolução, dinâmica e os processos dos diferentes sistemas naturais ao longo das quatro escalas temporais de análise: geológica, histórica, presente e futura, que dão suporte a diagnósticos e monitoramentos, assim como subsidiam o processo de uso e ocupação das terras mitigando os impactos ambientais. A compreensão dos sistemas naturais subsidiam políticas e planos de zoneamento ambiental de Unidades de Conservação da Natureza, bem como dão suporte a estudos que se preocupam com os efeitos advindos dos conflitos e impactos ambientais nos diferentes ambientes costeiros e continentais (UNIVERSIDADE FEDERAL FLUMINENSE, 2021).

Portanto, unindo a área de concentração com as duas linhas de pesquisa, podemos identificar os objetivos do PPG:

[...] aprimorar a formação de pesquisadores em nível de mestrado visando o desenvolvimento acadêmico e científico, assim como a formação de profissionais de alto nível para o exercício das atividades de ensino, pesquisa e extensão em geografia em todo território nacional. Além disso, espera-se que o egresso do Programa acumule 
capital humano geral e específico para construir, aplicar e divulgar conhecimento, contribuindo para o desenvolvimento da ciência geográfica no Brasil. Esse profissional deverá ainda estar apto a apreender os conteúdos teórico-metodológicos e aplicá-los aos problemas da realidade no seu exercício profissional, sejam eles oriundos de demandas regionais ou nacionais (UNIVERSIDADE FEDERAL FLUMINENSE, 2021).

Levando em consideração a maneira como o curso foi estruturado, vamos analisar as dissertações defendidas no PPG desde sua criação até o final do ano de 2020, de forma a constatar sua adequação à área de concentração e às linhas de pesquisa.

\section{As dissertações defendidas no PPG no período 2016-2020}

No Anexo 1, estão relacionadas todas as 66 dissertações defendidas desde a criação do PPG. Como sua primeira turma foi selecionada em 2014, as primeiras dissertações foram defendidas só no ano de 2016.

Na Tabela 1, estão as dissertações separadas por ano e por linha de pesquisa. Podemos perceber uma predominância da linha de "Análise Regional, Dinâmicas Territoriais e Escalas". Porém, se analisarmos apenas os anos de 2016, 2017 e 2018, chegamos a números bastante próximos: 53,5\% para a linha de "Análise Regional, Dinâmicas Territoriais e Escalas" e 46,5\% para a linha de "Sistemas Naturais, Geotecnologias e Demografia". Contudo, incluindo os anos de 2019 e 2020 , os números passam a $62 \%$ e $38 \%$, respectivamente. Somando todo o período, temos uma média de 13 dissertações defendidas por ano.

Em relação ao número de docentes, o PPG possuía, em 2014, 16 docentes, dos quais 14 permanentes, sendo 6 pertencentes à linha de "Análise Regional, Dinâmicas Territoriais e Escalas" e 8 pertencentes à linha de "Sistemas Naturais, Geotecnologias e Demografia", e 2 colaboradores, sendo um em cada uma das linhas de pesquisa.

Em 2020, o PPG contou 15 docentes permanentes, dos quais 8 pertenciam à linha de "Análise Regional, Dinâmicas Territoriais e Escalas" e 7 estavam ligados à linha de "Sistemas Naturais, Geotecnologias e Demografia", e 2 colaboradores, cada um pertencente a uma das linhas.

Portanto, de 2014 para 2020, houve um aumento na quantidade de docentes da primeira linha de pesquisa e uma diminuição da segunda, o que talvez ajude a explicar o menor número de defesas em "Sistemas Naturais, Geotecnologias e Demografia".

Tabela 1 - Número de dissertações defendidas no PPG no período 2016-2020, separados por linha de pesquisa.

\begin{tabular}{|llll}
\hline & $\begin{array}{l}\text { Análise Regional, } \\
\text { Dinâmicas Territoriais e } \\
\text { Escalas }\end{array}$ & $\begin{array}{l}\text { Sistemas Naturais, } \\
\text { Geotecnologias e } \\
\text { Demografia }\end{array}$ & TOTAL \\
\hline 2016 & 3 & 4 & 7 \\
\hline 2017 & 11 & 9 & 20 \\
\hline 2018 & 9 & 7 & 16 \\
\hline 2019 & 6 & 3 & 9 \\
\hline 2020 & 12 & 2 & 14 \\
\hline Subtotal por linha & 41 & 25 & 66 \\
\hline
\end{tabular}

Fonte: elaborada pelo autor. 


\section{Recortes Espaciais}

Muito importante em Geografia é delimitar os recortes espaciais da pesquisa, os marcos espaciais em que a pesquisa ocorrerá. Castro $(2014$, p. 88$)$ entende a escala geográfica "como um problema operacional fundamental na definição do recorte espacial significativo para a análise do fenômeno na pesquisa em geografia”. Para ela, refletir sobre

[...] a escala na geografia é necessariamente tomar o fenômeno e sua extensão espacial, independente do ator responsável por ele, considerando que este é o problema central para qualquer pesquisa na disciplina. $O$ recurso de pensar a escala permite analisar o fenômeno a partir da medida da sua significância, isto é, da extensão que lhe dá sentido. Deixando claro que para a pesquisa nem o fenômeno, nem a escala de análise são dados da natureza, mas escolhas intelectuais fortemente influenciadas pelas matrizes teóricas dos pesquisadores e pelos seus contextos sociais.

Portanto, a análise que aqui realizamos busca averiguar as escolhas realizadas pelos agora egressos do PPG na construção de seus objetos teóricos e empíricos de investigação, podendo, então, verificar se os objetivos iniciais do PPG, de voltar-se para as questões da região de Campos dos Goytacazes e das regiões vizinhas do Norte e Noroeste Fluminenses, foram, de fato, priorizados nos recortes espaciais das pesquisas desenvolvidas.

$\mathrm{Na}$ Tabela 2, temos os recortes espaciais identificados nas dissertações defendidas no PPG. Para tanto, consideramos a indicação espacial presente no título. Já nos casos dos trabalhos em que tal indicação não estava definida, o recorte espacial foi apontado como "indefinido".

Simplificando os dados da Tabela 2, chegamos à Tabela 3, fazendo a ressalva de que existe a sobreposição de alguns trabalhos, sendo que, nesses casos, foi privilegiada a escala mais próxima a Campos dos Goytacazes/RJ.

Encontramos, portanto, 24 indicações da cidade de Campos dos Goytacazes/RJ, local de funcionamento do PPG, correspondendo a 36,36\% das dissertações; Onze trabalhos não tiveram indicação do recorte espacial no título (16,67\%), sendo considerados como "indefinidos"; Três indicaram claramente a região Norte Fluminense como seu recorte espacial; Quatro apontaram cidades da região Norte Fluminense (São João da Barra, com três 3 indicações, e Carapebus, com uma1); e um que indicou o Rio Paraíba do Sul, no trecho referente às regiões Norte e Noroeste Fluminenses; dois trabalhos indicaram a região Noroeste Fluminense (um sobre a cidade de Itaperuna; e o outro envolveu uma

Tabela 2 - Recortes espaciais identificados nas dissertações defendidas no PPG, 2016-2020.

\begin{tabular}{|llll}
\hline 1 & Indefinido & 34 & Campos dos Goytacazes \\
\hline 2 & Rio de Janeiro (estado) & 35 & Indefinido \\
\hline 3 & Porto do Açu & 36 & Campos dos Goytacazes \\
\hline 4 & Itaperuna/RJ & 37 & Indefinido \\
\hline 5 & Indefinido & 38 & Campos dos Goytacazes \\
\hline 6 & Indefinido & 39 & São João da Barra/RJ \\
\hline 7 & Indefinido & 40 & Indefinido \\
\hline
\end{tabular}

Fonte: elaborada pelo autor com dados do Anexo 1.

Obs.: A numeração se refere à ordem das dissertações apresentadas no Anexo 1. 
Tabela 2 - Continuação...

\begin{tabular}{|c|c|c|c|}
\hline 8 & Petrópolis/RJ & 41 & Araruama/RJ \\
\hline 9 & Campos dos Goytacazes e Macaé & 42 & Campos dos Goytacazes \\
\hline 10 & Guiné-Bissau (África) & 43 & Campos dos Goytacazes \\
\hline 11 & Cabo Frio/RJ (Rio de Janeiro) & 44 & Niterói/RJ \\
\hline 12 & Campos dos Goytacazes & 45 & Campos dos Goytacazes \\
\hline 13 & Espírito Santo & 46 & Espera Feliz/MG \\
\hline 14 & Espírito Santo & 47 & Brasil \\
\hline 15 & Campos dos Goytacazes & 48 & Porto Alegre/RS \\
\hline 16 & Campos dos Goytacazes & 49 & Campos dos Goytacazes \\
\hline 17 & Indefinido & 50 & Indefinido \\
\hline 18 & Rio de Janeiro (estado) & 51 & Norte Fluminense \\
\hline 19 & Brasil & 52 & Campos dos Goytacazes \\
\hline 20 & Suzano/SP & 53 & Viçosa/MG \\
\hline 21 & Rio de Janeiro (estado) & 54 & Rio de Janeiro (estado) \\
\hline 22 & Indefinido & 55 & Porto Seguro/BA \\
\hline 23 & Campos dos Goytacazes & 56 & Norte Fluminense \\
\hline 24 & Campos dos Goytacazes & 57 & Campos dos Goytacazes \\
\hline 25 & $\begin{array}{l}\text { Bom Jesus do Itabapoana/RJ e Bom Jesus } \\
\text { do Norte/ES }\end{array}$ & 58 & $\begin{array}{l}\text { Rio Paraíba do Sul (regiões Norte } \\
\text { Fluminense e Noroeste Fluminense) }\end{array}$ \\
\hline 26 & Indefinido & 59 & Uberaba/MG \\
\hline 27 & Campos dos Goytacazes & 60 & Carapebus/RJ \\
\hline 28 & Campos dos Goytacazes & 61 & São João da Barra/RJ \\
\hline 29 & Campos dos Goytacazes & 62 & Campos dos Goytacazes \\
\hline 30 & Campos dos Goytacazes & 63 & Norte Fluminense \\
\hline 31 & Campos dos Goytacazes & 64 & Campos dos Goytacazes \\
\hline 32 & Campos dos Goytacazes & 65 & Aparecida/SP \\
\hline 33 & Rio de Janeiro (estado) & 66 & Campos dos Goytacazes \\
\hline
\end{tabular}

Fonte: elaborada pelo autor com dados do Anexo 1.

Obs.: A numeração se refere à ordem das dissertações apresentadas no Anexo 1.

Tabela 3 - Classificação dos recortes espaciais encontrados na Tabela 2.

\begin{tabular}{lll}
\hline Recortes espaciais & Quantidade & Percentual \\
\hline Campos dos Goytacazes & 24 & $36,36 \%$ \\
\hline Região Norte Fluminense & 8 & $12,12 \%$ \\
\hline Região Noroeste Fluminense & 2 & $3,03 \%$ \\
\hline Rio de Janeiro (cidades e estado) & 9 & $13,64 \%$ \\
\hline Outros estados da região Sudeste & 7 & $10,61 \%$ \\
\hline Outras regiões brasileiras (Rio Grande do Sul e Bahia) & 2 & $3,03 \%$ \\
\hline Escala nacional & 2 & $3,03 \%$ \\
\hline Escala internacional (Guiné-Bissau) & 1 & $1,51 \%$ \\
\hline Recorte espacial indefinido & 11 & $16,67 \%$ \\
\hline TOTAL & 66 & $100,00 \%$
\end{tabular}

Fonte: elaborada pelo autor.

Observação: no caso de sobreposição de escalas, foi privilegiada a mais próxima da cidade de Campos dos Goytacazes/RJ. 


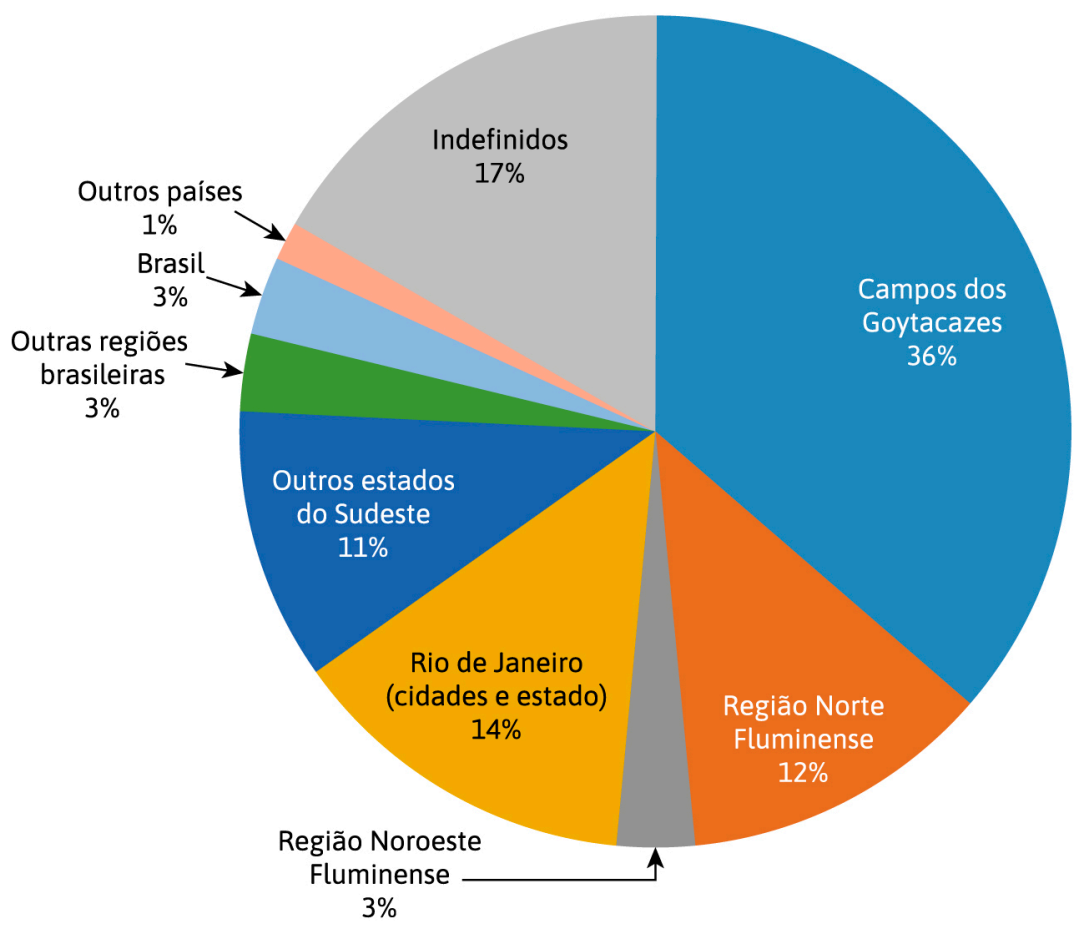

Figura 1 - Percentual dos recortes espaciais das dissertações do PPG, 2016-2020.

Fonte: elaborada pelo autor com dados da Tabela 3.

cidade do Noroeste Fluminense (Itaperuna) e outra uma cidade do estado do Espírito Santo). Portanto, somando os trabalhos da região Norte Fluminense com os da região Noroeste Fluminense, foram outros dez 10 trabalhos, que corresponderam a 15,15\% das dissertações. Além disso, nove trabalhos $(13,63 \%)$ realizaram como recorte espacial o estado do Rio de Janeiro ou cidades de outras regiões do estado, excluindo as regiões Norte e Noroeste Fluminense, que tiveram contabilização própria.

Sobre esses recortes espaciais mais próximos, destacamos aqui também: três trabalhos sobre o Espírito Santo (um já citado antes, que reuniu uma cidade capixaba com outra da região Noroeste Fluminense), três que envolveram cidades de Minas Gerais (Espera Feliz, Uberaba e Viçosa), dois referentes a cidades de São Paulo (Suzano e Aparecida), um sobre o Rio Grande do Sul (Porto Alegre) e um sobre a Bahia (Porto Seguro). Ainda, temos dois trabalhos da escala nacional e um da escala internacional, que versou sobre Guiné-Bissau (Figura 1).

\section{Considerações Finais}

Apresentamos, brevemente, alguns dados que podem servir para construir o histórico do curso, bem como contribuir para a melhoria de certos indicadores, analisando, por exemplo, a distribuição das dissertações defendidas em cada uma das linhas de pesquisa do curso. Deste modo, estamos colaborando com a autoavaliação exigidas pelos órgãos reguladores da pós-graduação brasileira.

A vocação regional do curso é comprovada quando vemos que $51,51 \%$ das dissertações apresentadas no PPG estão relacionadas à cidade de Campos dos Goytacazes ou às regiões 
Norte e Noroeste Fluminenses. Somando as referências ao estado do Rio de Janeiro e suas cidades, esse número sobre para $65,15 \%$ das dissertações.

Acrescentamos a isso a reflexão teórica, sempre necessária ao desenvolvimento da disciplina geográfica, presente nos trabalhos sem uma definição clara do recorte espacial. Destacamos ainda as menções aos estados do Espírito Santo e de Minas Gerais, que também podemos considerar como estando dentro da zona de abrangência do PPG.

Mesmo os recortes espaciais do Brasil e de estados como Rio Grande do Sul, São Paulo e Bahia mostram o espraiamento da reflexão teórica e prática do PPG, chegando até a escala internacional, com o trabalho sobre Guiné-Bissau, na África.

Portanto, com este trabalho, iniciamos uma reflexão sobre a produção do PPG, que pode ser estendida à realização de outras pesquisas e análises sobre as dissertações defendidas, servindo como indicadores para a melhoria constante do PPG em Geografia da UFF/Campos. Esse é o exigido na autoavaliação do PPG, tal qual é o objetivo de seus docentes, discentes e técnicos, sempre buscando uma educação gratuita e de qualidade, colaborando para a melhoria das condições de vida da população brasileira.

\section{Referências}

COORDENAÇÃO DE APERFEIÇOAMENTO DE PESSOAL DE NÍVEL SUPERIOR - CAPES. Autoavaliação de programas de Pós-graduação: grupo de trabalho. Brasília: CAPES, 2019. Disponível em: <https:// www.gov.br/capes/pt-br/centrais-de-conteudo/10062019-autoavaliacao-de-programas-de-pos-graduacaopdf>. Acesso em: 9 abr. 2021.

COORDENAÇÃO DE APERFEIÇOAMENTO DE PESSOAL DE NÍVEL SUPERIOR - CAPES. Ficha de avaliação. Brasília: CAPES, 2020. Disponível em: <https://www.gov.br/capes/pt-br/acesso-a-informacao/ acoes-e-programas/avaliacao/sobre-a-avaliacao/areas-avaliacao/sobre-as-areas-de-avaliacao/colegiode-humanidades/ciencias-humanas/geografia>. Acesso em: 9 abr. 2021.

CASTRO, I. E. Escala e pesquisa na geografia: problema ou solução? Revista Espaço Aberto: Revista do Programa de Pós-graduação em Geografia, Niterói, v. 4. n. 1, 2014.

UNIVERSIDADE FEDERAL FLUMINENSE - UFF. Programa de Pós-graduação em Geografia - PPG. Descrição do Programa. Niterói, 2021. Disponível em: <http://www.ppg.uff.br/index.php/area-deconcentracao/>. Acesso em 10 abr. 2021. 


\section{ANEXO 1 - DISSERTAÇÕES DEFENDIDAS NO PPG NO PERÍODO 2016-2020}

2020

ALVES, Hortencia de Jesus Rodrigues. Mirando as Tecnologias: aprendizagens de geografias vizinhas. Dissertação (Mestrado em Geografia) - Programa de Pós-Graduação em Geografia, Universidade Federal Fluminense. Campos dos Goytacazes, 2020.

DIAS, Jeniffer Silvana da Silva. A Política de Abastecimento de Gêneros Agrícolas e o Sistema Ceasa no Estado do Rio De Janeiro. Dissertação (Mestrado em Geografia) - Programa de Pós-Graduação em Geografia, Universidade Federal Fluminense. Campos dos Goytacazes, 2020.

BARRETO, Nina Maria de Souza. O Porto Do Açu (RJ): A Superexploração do Trabalho e os Conflitos Sócio-Espaciais. Dissertação (Mestrado em Geografia) - Programa de Pós-Graduação em Geografia, Universidade Federal Fluminense. Campos dos Goytacazes, 2020.

GONÇALVES, Mylena André. Centralidade Interurbana de Itaperuna - RJ: Uma Análise das Atividades de Comércio e Serviços. Dissertação (Mestrado em Geografia) - Programa de Pós-Graduação em Geografia, Universidade Federal Fluminense. Campos dos Goytacazes, 2020.

SOARES, Edmilson Campos. Cidade-Negócio e Responsabilidade Social Empresarial: Uma Análise Crítica da ONG Teto e Seus Financiadores. Dissertação (Mestrado em Geografia) - Programa de PósGraduação em Geografia, Universidade Federal Fluminense. Campos dos Goytacazes, 2020.

CUNHA, Andreia Ribeiro. "Do Rap ao Batidão” A Formação Político-Cultural Periférica e o Protagonismo da Mulher nos Movimentos Funk e Hip Hop: Contradições, Limites e Conflitos (Mestrado em Geografia) - Programa de Pós-Graduação em Geografia, Universidade Federal Fluminense. Campos dos Goytacazes, 2020.

CRUZ, Pamela de Souza da. Os Sentidos da Geografia Histórica na Revista Brasileira de Geografia (1939-1948) (Mestrado em Geografia) - Programa de Pós-Graduação em Geografia, Universidade Federal Fluminense. Campos dos Goytacazes, 2020.

WERNECK, Carlos Renato Ricardo. O Evento Catastrófico em Teresópolis/RJ e a Criação do Conjunto Habitacional Parque Ermitage, 2011-2019 (Mestrado em Geografia) - Programa de Pós-Graduação em Geografia, Universidade Federal Fluminense. Campos dos Goytacazes, 2020.

TAVARES, Thais Dias. "Respeite As Minas”: A Territorialidade Feminina no Movimento Hip-Hop em Campos dos Goytacazes e Macaé (Mestrado em Geografia) - Programa de Pós-Graduação em Geografia, Universidade Federal Fluminense. Campos dos Goytacazes, 2020.

PACHECO JUNIOR, Nelson Cortes. Da Capital às Tabancas: A Lugaridade entre os Guineenses e Missionários Protestantes em Guiné-Bissau (Mestrado em Geografia) - Programa de Pós-Graduação em Geografia, Universidade Federal Fluminense. Campos dos Goytacazes, 2020.

MARQUeS, Gabriel Guanabara Lemos. Plano Participativo de Mobilidade Urbana de Cabo Frio - RJ: Desafios e Possibilidades (Mestrado em Geografia) - Programa de Pós-Graduação em Geografia, Universidade Federal Fluminense. Campos dos Goytacazes, 2020.

SILVA, Anderson Luiz Barreto da. Religiões Afro-Brasileiras em Campos dos Goytacazes: Territórios, Conflitos e Resistência (Mestrado em Geografia) - Programa de Pós-Graduação em Geografia, Universidade Federal Fluminense. Campos dos Goytacazes, 2020.

ABREU, Juliana Silva de. Distribuição Geográfica da Pesca Marinha em Relação ao Recife Artificial Navio Victory 8b, Espírito Santo: Uma Análise a Partir do Conhecimento Tradicional de Pescadores Artesanais (Mestrado em Geografia) - Programa de Pós-Graduação em Geografia, Universidade Federal Fluminense. Campos dos Goytacazes, 2020.

OLIVEIRA, Pablo da Costa. Viabilidade da Pesca Artesanal Frente aos Rejeitos de Minério Lançados na Costa Norte do Espírito Santo: Uso do Conhecimento Tradicional (Mestrado em Geografia) - Programa de Pós-Graduação em Geografia, Universidade Federal Fluminense. Campos dos Goytacazes, 2020.

\section{9}

BASTOS, Raquel Figueira. Unidades de Conservação Ambiental no município de Campos dos Goytacazes - RJ (Mestrado em Geografia) - Programa de Pós-Graduação em Geografia, Universidade Federal Fluminense. Campos dos Goytacazes, 2019. 
BARBOSA, Antonio Ivo Gomes. Estimativa da Área Plantada de Cana-De-Açúcar em Campos dos Goytacazes - RJ Utilizando Sensoriamento Remoto (Mestrado em Geografia) - Programa de PósGraduação em Geografia, Universidade Federal Fluminense. Campos dos Goytacazes, 2019.

ARAUJO, Dayana Paes de. A Construção da Geografia Humana no Cruzamento do Evolucionismo Positivista com as Correntes Idealistas: Desarticulação do Projeto Científico Integrador? (Mestrado em Geografia) - Programa de Pós-Graduação em Geografia, Universidade Federal Fluminense. Campos dos Goytacazes, 2019.

COSTA, Layon Ignacio da Silva. Dinâmica Econômica e Locacional dos Investimentos na Indústria Fluminense (2010-2017) (Mestrado em Geografia) - Programa de Pós-Graduação em Geografia, Universidade Federal Fluminense. Campos dos Goytacazes, 2019.

CLARO JUNIOR, Jose Augusto. Estado e Dinâmica Econômica e Espacial da Indústria Automobilística no Brasil No Século XXI (Mestrado em Geografia) - Programa de Pós-Graduação em Geografia, Universidade Federal Fluminense. Campos dos Goytacazes, 2019.

SOUZA, Anderson Aparecido de. Políticas Territoriais e Segregação Socioespacial. Análise do Programa Minha Casa Minha Vida em Suzano-SP (Mestrado em Geografia) - Programa de Pós-Graduação em Geografia, Universidade Federal Fluminense. Campos dos Goytacazes, 2019.

VERLING, Yago de Souza. Zoneamento Ambiental do Trecho Fluminense da Bacia Hidrográfica do Rio Itabapoana - Brasil (Mestrado em Geografia) - Programa de Pós-Graduação em Geografia, Universidade Federal Fluminense. Campos dos Goytacazes, 2019.

SILVA, Ralfe de Souza Medeiros da. O Jogo De Xadrez como Recurso Metodológico na Elaboração de Mapas Mentais (Mestrado em Geografia) - Programa de Pós-Graduação em Geografia, Universidade Federal Fluminense. Campos dos Goytacazes, 2019.

NOGUEIRA, Fernanda de Faria Viana. De Quem São os Lugares na Cidade? Entendendo Trajetórias Gays em Campos dos Goytacazes - RJ (Mestrado em Geografia) - Programa de Pós-Graduação em Geografia, Universidade Federal Fluminense. Campos dos Goytacazes, 2019.

2018

ALMEIDA, Carolina Vieira Caldeira de Lima de Souza. Desenvolvimento de Práticas Educativas em Ensino de Geografia com alunos do $1^{\circ}$ ano do Ensino Médio da Rede Pública de Ururaí, Campos Dos Goytacazes (RJ), sob a Perspectiva do Fenômeno Inundação (Mestrado em Geografia) - Programa de Pós-Graduação em Geografia, Universidade Federal Fluminense. Campos dos Goytacazes, 2018.

TIRADENTES, Marlucia Degli Esposti. Vulnerabilidade e Risco de Inundação nos Municípios de Bom Jesus do Itabapoana (RJ) e Bom Jesus do Norte (ES) (Mestrado em Geografia) - Programa de PósGraduação em Geografia, Universidade Federal Fluminense. Campos dos Goytacazes, 2018.

QUEIROZ, Guilherme de Oliveira. A Política em Paul Vidal De La Blache: Resgate de um Ponto Chave (Mestrado em Geografia) - Programa de Pós-Graduação em Geografia, Universidade Federal Fluminense. Campos dos Goytacazes, 2018.

SILVA, Neusa Regina Barros Bastos da. Reflexões Sobre a Formação da Comunidade do Terminal Pesqueiro, em Farol de São Tomé, Campos dos Goytacazes - RJ e sua Identificação ao Lugar, Sob a Ótica Topofílica de Yi-Fu Tuan (Mestrado em Geografia) - Programa de Pós-Graduação em Geografia, Universidade Federal Fluminense. Campos dos Goytacazes, 2018.

SOUZA, Luma da Silva. Segregação Socioespacial e Política habitacional em Campos dos Goytacazes (RJ): Um estudo de caso sobre o Programa Morar Feliz em Ururaí (Mestrado em Geografia) - Programa de Pós-Graduação em Geografia, Universidade Federal Fluminense. Campos dos Goytacazes, 2018.

SILVA, Diogo Jordao. População em situação de rua e os usos do território: Uma análise das estratégias de sobrevivência na área central de Campos dos Goytacazes (Mestrado em Geografia) - Programa de Pós-Graduação em Geografia, Universidade Federal Fluminense. Campos dos Goytacazes, 2018.

MARTINS, Fabio Gustavo Pontes. A construção de condomínios no bairro Jockey Club: Um processo de exclusão socioespacial? (Mestrado em Geografia) - Programa de Pós-Graduação em Geografia, Universidade Federal Fluminense. Campos dos Goytacazes, 2018.

RANGEL, Arthur Nogueira. As ações dos grafiteiros e a produção da nova paisagem urbana de Campos dos Goytacazes (Mestrado em Geografia) - Programa de Pós-Graduação em Geografia, Universidade Federal Fluminense. Campos dos Goytacazes, 2018. 
TAVARES, Mariana Machado. A formação Geohistórica da Favela Baleeira em Campos dos Goytacazes - RJ (Mestrado em Geografia) - Programa de Pós-Graduação em Geografia, Universidade Federal Fluminense. Campos dos Goytacazes, 2018.

BARCELOS, Daniel Ribeiro. Guerra Fiscal e alienação do território no Estado do Rio de Janeiro (Mestrado em Geografia) - Programa de Pós-Graduação em Geografia, Universidade Federal Fluminense. Campos dos Goytacazes, 2018.

CUNHA, Thiago Ferreira da. Distribuição Espacial dos Casos de Notificações e Focos da Dengue no Município de Campos dos Goytacazes, Entre os Anos de 2011 a 2015, Utilizando Técnicas de Geoprocessamento (Mestrado em Geografia) - Programa de Pós-Graduação em Geografia, Universidade Federal Fluminense. Campos dos Goytacazes, 2018.

SANGUEDO, Juliana Bastos. Proposta de Construção de Índice Sintético de vulnerabilidade domiciliar a partir de dados dos censos demográficos brasileiros (Mestrado em Geografia) - Programa de PósGraduação em Geografia, Universidade Federal Fluminense. Campos dos Goytacazes, 2018.

BATISTA, Henrique Ferreira. Centro, Centralidade e Cidade Média: O Papel do Comércio e Serviços na Reestruturação da Cidade de Campos dos Goytacazes- RJ (Mestrado em Geografia) - Programa de Pós-Graduação em Geografia, Universidade Federal Fluminense. Campos dos Goytacazes, 2018.

SALES, Vanessa Barbosa. Indicador de Vulnerabilidade Socioambiental: Uma proposta metodológica em nível do indivíduo (Mestrado em Geografia) - Programa de Pós-Graduação em Geografia, Universidade Federal Fluminense. Campos dos Goytacazes, 2018.

SANTOS, Cleber de Jesus. Avaliação do Aquífero Raso no Parque São Benedito, Campos dos Goytacazes, Rj, Utilizando Geofísica e Exames Laboratoriais (Mestrado em Geografia) - Programa de Pós-Graduação em Geografia, Universidade Federal Fluminense. Campos dos Goytacazes, 2018.

LAMMLE, Luca. Impactos de Obras costeiras na linha de costa: O caso do Porto do Açu, São João da Barra, RJ (Mestrado em Geografia) - Programa de Pós-Graduação em Geografia, Universidade Federal Fluminense. Campos dos Goytacazes, 2018.

2017

COIMBRA, Thaina Santos. Geografia Com Tic's Cotidianas (Mestrado em Geografia) - Programa de Pós-Graduação em Geografia, Universidade Federal Fluminense. Campos dos Goytacazes, 2017.

AZEVEDO, Maria Catarina da Silva. As Transformações na Cobertura, Uso e Ocupação da Terra e Suas Consequências Sobre os Canais Fluviais: Análise das Inundações na Bacia do Rio Mataruna/ Araruama - RJ (Mestrado em Geografia) - Programa de Pós-Graduação em Geografia, Universidade Federal Fluminense. Campos dos Goytacazes, 2017.

CRESPO, Romulo De Almeida Beraldi. Instituindo a Aproximação Entre os Profissionais de Geografia e a Observação de Campo: A Discussão de Diferentes Tipologias de Trabalho de Campo Tendo Como Área de Estudo a Lagoa do Vigário em Campos dos Goytacazes-RJ (Mestrado em Geografia) - Programa de Pós-Graduação em Geografia, Universidade Federal Fluminense. Campos dos Goytacazes, 2017.

SILVA, Joilson Bessa da. Salas de Cinema em Campos dos Goytacazes: Lugar, Sociabilidade e Políticas Culturais - da década de 1960 aos anos 2010 (Mestrado em Geografia) - Programa de Pós-Graduação em Geografia, Universidade Federal Fluminense. Campos dos Goytacazes, 2017.

GAMA, Joao Penido. Técnica Survey Para Análise Espacial e Perfil dos Usuários: Uma Aplicação Para a Área Central de Niterói/RJ (Mestrado em Geografia) - Programa de Pós-Graduação em Geografia, Universidade Federal Fluminense. Campos dos Goytacazes, 2017.

FERES, Vinicius Soares Rangel Gomes. O Circuito inferior da economia urbana em Campos dos Goytacazes (Mestrado em Geografia) - Programa de Pós-Graduação em Geografia, Universidade Federal Fluminense. Campos dos Goytacazes, 2017.

CHAMBELA, Fernanda Aparecida. Análise da Rede Geográfica e da Perda de Densidade da Associação de Mulheres Rurais do Município de Espera Feliz - MG (Mestrado em Geografia) - Programa de PósGraduação em Geografia, Universidade Federal Fluminense. Campos dos Goytacazes, 2017.

GOVEIA, Luis Alberto Miranda. A internacionalização das empresas brasileiras durante os governos de Fernando Henrique Cardoso e Luiz Inácio Lula da Silva (Mestrado em Geografia) - Programa de Pós-Graduação em Geografia, Universidade Federal Fluminense. Campos dos Goytacazes, 2017.

ALVES, Priscila Viana. Experiências Poéticas em Porto Alegre: uma leitura geográfica de Mario Quintana (Mestrado em Geografia) - Programa de Pós-Graduação em Geografia, Universidade Federal Fluminense. Campos dos Goytacazes, 2017. 
PERES, Jose Felippe da Silva. Produção e Fragmentação do Espaço Urbano e o Direito à Cidade: Uma Analise do Programa "Morar Feliz" entre os Moradores dos Conjuntos Tapera II E Ururai II (Mestrado em Geografia) - Programa de Pós-Graduação em Geografia, Universidade Federal Fluminense. Campos dos Goytacazes, 2017.

COUTINHO, Edlane da Cruz da Silva. Geografia nas Provas do Enem: Abordagens Para Uma Compreensão Interdisciplinar (Mestrado em Geografia) - Programa de Pós-Graduação em Geografia, Universidade Federal Fluminense. Campos dos Goytacazes, 2017.

CRUZ, Maria Cecilia Soares. Território e Sindicalismo no Brasil: Uma Análise a Partir do Sindicato dos Petroleiros do Norte Fluminense (Mestrado em Geografia) - Programa de Pós-Graduação em Geografia, Universidade Federal Fluminense. Campos dos Goytacazes, 2017.

FIRMO JUNIOR, Reginaldo. Uso de Diferentes Representações Cartográficas no Ensino de Geografia no Ensino Médio: um estudo de caso no Colégio Estadual Dr. Phillippe Uebe, Campos dos Goytacazes-RJ (Mestrado em Geografia) - Programa de Pós-Graduação em Geografia, Universidade Federal Fluminense. Campos dos Goytacazes, 2017.

AMARAL, Cinthia Maria. Áreas de Risco e Vulnerabilidade Social em Áreas Urbanas: Soluções de Mapeamento Com Técnicas de Geotecnologias Para Viçosa-MG (Mestrado em Geografia) - Programa de Pós-Graduação em Geografia, Universidade Federal Fluminense. Campos dos Goytacazes, 2017.

VIRTUOSO, Anadelson Martins. Mapeamento da Cobertura e Uso da Terra Nas Faixas Marginais de Proteção do Rio Muriaé no Estado do Rio De Janeiro (Mestrado em Geografia) - Programa de PósGraduação em Geografia, Universidade Federal Fluminense. Campos dos Goytacazes, 2017.

VEIGA, Ronaldo de Souza. Uso e Ocupação da Terra no Município de Porto Seguro, BA: Uma Análise Geoambiental Multitemporal (1985-2016) (Mestrado em Geografia) - Programa de Pós-Graduação em Geografia, Universidade Federal Fluminense. Campos dos Goytacazes, 2017.

PAES, Raquel da Silva. Agricultura Familiar Versus Salinização: Uma Abordagem Etnopedológica no Norte Fluminense (Mestrado em Geografia) - Programa de Pós-Graduação em Geografia, Universidade Federal Fluminense. Campos dos Goytacazes, 2017.

SANT ANNA, Aline Guimaraes de Souza. As Praças e os Conteúdos das Desigualdades Socioespaciais Urbanas em Campos dos Goytacazes-RJ (Mestrado em Geografia) - Programa de Pós-Graduação em Geografia, Universidade Federal Fluminense. Campos dos Goytacazes, 2017.

RAIMUNDO, Amaral Morais. Geograficidades dos Pescadores Artesanais do Médio Inferior do Rio Paraíba do Sul (Mestrado em Geografia) - Programa de Pós-Graduação em Geografia, Universidade Federal Fluminense. Campos dos Goytacazes, 2017.

FARIA, Raphael Felix Ribeiro. Passos e Descompassos da Política de Mobilidade Urbana em Cidades de Porte Médio: O Sistema de Transporte Público BRT em Uberaba-MG (Mestrado em Geografia) - Programa de Pós-Graduação em Geografia, Universidade Federal Fluminense. Campos dos Goytacazes, 2017.

2016

CORREA, Sueleni Carvalho Fontes. Contribuição Aos Estudos Geomorfológicos e Sedimentológicos na Lagoa de Carapebus, RJ (Mestrado em Geografia) - Programa de Pós-Graduação em Geografia, Universidade Federal Fluminense. Campos dos Goytacazes, 2016.

LEANDRO, Assis Rangel. Impactos Socioeconômicos da Implantação do Complexo Logístico e Industrial do Porto do Açu no Distrito de Pipeiras São João da Barra - RJ (Mestrado em Geografia) - Programa de Pós-Graduação em Geografia, Universidade Federal Fluminense. Campos dos Goytacazes, 2016.

GAMA, Everton dos Santos da Silva. Zoneamento Ambiental do Município de Campos dos Goytacazes-RJ (Mestrado em Geografia) - Programa de Pós-Graduação em Geografia, Universidade Federal Fluminense. Campos dos Goytacazes, 2016.

TAVARES, Jessica Monteiro da Silva. Movimentos Pendulares de Estudantes na Região Norte Fluminense (Mestrado em Geografia) - Programa de Pós-Graduação em Geografia, Universidade Federal Fluminense. Campos dos Goytacazes, 2016.

RODRIGUES, Igor Paolo Ribeiro Dias. Território e Poder: As Elites e a Organização do Território em Campos dos Goytacazes (Mestrado em Geografia) - Programa de Pós-Graduação em Geografia, Universidade Federal Fluminense. Campos dos Goytacazes, 2016.

BARBOSA, Ivo Francisco. A Produção do Espaço Urbano em Aparecida - SP: Agentes e Processos (Mestrado em Geografia) - Programa de Pós-Graduação em Geografia, Universidade Federal Fluminense. Campos dos Goytacazes, 2016. 
CONCEICAO, Raphael Neves da. Leituras Geohistóricas da Paisagem da Baixada Campista (Mestrado em Geografia) - Programa de Pós-Graduação em Geografia, Universidade Federal Fluminense. Campos dos Goytacazes, 2016.pre

SOBRE O AUTOR

Marcelo Werner da Silva (SILVA, M. W.). Coordenador do Programa de Pós-Graduação em Geografia da Universidade Federal Fluminense, em Campos dos Goytacazes (UFF/Campos). Coordenador do Grupo de Estudos e Pesquisas de Geografia Histórica (Geohistórica). 
Índice

de autores 
A

Adriana Filgueira Leite

Arthur Soffiati

B

Bruna Almeida Ribeiro 185

D

Daniel de Albuquerque Ribeiro $.8,48,100$

E

Edimilson Antonio Mota 89,119

Elaine C R Mendes Emerick 132

Elaine Guimaraes Godinho 89

Elzira Lucia de Oliveira 132

Erika Vanessa Moreira Santos. ... 146

$\mathbf{F}$

Felicio Alves de Azeredo 119

G

Gabrielle Lorena Gomes da Silva . .31

Glauco Bruce Rodrigues
J

Jenyffer Vidal Oliveira 31

L

Leandro Bruno Santos 163

\section{M}

Marcelo Werner da Silva 8,203

Marcia Aparecida Pereira de Mellob........... 119

Marco Tulio Morais Velasque Silva 146

\section{$\mathbf{R}$}

Renata Hilel Ribeiro 31

Ruy Moreira 10

S

Samara Venina Simen de Azeredo Silva Chagas ........................................................ 146 Silvana Cristina da Silva ................................. 31

$\mathbf{T}$

Tatiana Tramontani Ramos......................... 8, 13 
Com este trabalho, iniciamos uma reflexão sobre a produção do Programa de Pós-Graduação em Geografia (PPG) da Universidade Federal Fluminense de Campos dos Goytacazes (UFF/Campos), que pode ser estendida à realização de outras pesquisas e análises sobre as dissertações defendidas, servindo como indicadores para a melhoria constante do Programa. Esse é o exigido na autoavaliação do PPG, tal qual é o objetivo de seus docentes, discentes e técnicos, sempre buscando uma educação gratuita e de qualidade, colaborando para a melhoria das condições de vida da população brasileira.

(Marcelo Werner da Silva, 2021) 